\title{
Hydrological and biogeochemical cycling along the Greenland ice sheet margin
}

\author{
by \\ Maya Pilar Bhatia \\ B.S., Queen's University (Kingston, Canada), 2001 \\ M.S., University of Alberta (Edmonton, Canada), 2004 \\ Submitted in partial fulfillment of the requirements for the degree of \\ Doctor of Philosophy \\ at the \\ MASSACHUSETTS INSTITUTE OF TECHNOLOGY \\ and the \\ WOODS HOLE OCEANOGRAPHIC INSTITUTION
}

February 2012

(C) 2012 Maya Pilar Bhatia.

All rights reserved.

The author hereby grants MIT and WHOI permission to reproduce and to distribute publicly paper and electronic copies of this thesis document in whole or in part in any medium now known or hereafter created.

Author

Joint Program in Oceanography/Applied Ocean Science and Engineering Massachusetts Institute of Technology and Woods Hole Oceanographic Institution

Certified by

Sarah B. Das

Thesis Co-Supervisor

Certified by

Elizabeth B. Kujawinski

Thesis Co-Supervisor

Accepted by

Rob L. Evans

Senior Scientist, Department of Geology and Geophysics, WHOI

Chairman, Joint Committee for Geology and Geophysics 


\title{
Hydrological and biogeochemical cycling along the Greenland ice sheet margin
}

\author{
by \\ Maya Pilar Bhatia \\ Submitted to the Department of Marine Geology and Geophysics, \\ MIT/WHOI Joint Program in Oceanography/Applied Ocean Science and \\ Engineering on December 30, 2011 in partial fulfillment of the requirements \\ for the degree of Doctor of Philosophy
}

\begin{abstract}
Global warming has led to a significant increase in Greenland ice sheet (GrIS) melt and runoff since 1990, resulting in escalated export of fresh water and associated sediment to the surrounding North Atlantic and Arctic Oceans. Similar to alpine glacial systems, surface meltwater on ice sheet surface drains to the base (subglacial) where it joins a drainage system and can become chemically enriched from its origin as dilute snow- and ice-melt. In this thesis, I examine the interdependence of glacial hydrology and biogeochemical cycling in terms of export of carbon and iron from the Greenland ice sheet. I develop a new isotope mixing-model to quantify water source contributions to the bulk meltwater discharge draining a GrIS outlet glacier. Results illustrate (a) the new application of a naturally occurring radioisotope (radon-222) as a quantitative tracer for waters stored at the glacier bed, and (b) the seasonal evolution of the subglacial drainage network from a delayed-flow to a quick-flow system. Model results also provide the necessary hydrological context to interpret and quantify glacially-derived organic carbon and iron fluxes. I combine bulk- and molecular-level studies of subglacial organic carbon to show that GrIS discharge exports old (radiocarbon depleted), labile organic matter. Similar investigations of dissolved and particulate iron reveal that GrIS discharge may be a significant flux of labile iron to the North Atlantic Ocean during the summer meltseason. Both carbon and iron are subject to proglacial processing prior to export to the marine environment, and exhibit strong seasonal variability in correlation with the subglacial drainage evolution. Low, chemically concentrated fluxes characterize the spring discharge, whereas higher, chemically dilute fluxes typify the summer discharge. Collectively, this thesis provides some of the first descriptions and flux estimates of carbon and iron, key elements in ocean biogeochemical cycles, in GrIS meltwater runoff.
\end{abstract}




\section{Acknowledgments}

This thesis represents over half a decade of work for which there is a village of people to thank. First and foremost, my co-advisors, Elizabeth Kujawinski and Sarah Das: I feel so fortunate to have had the chance to work with such amazing scientists. I indebted to them for taking me on when we only had unfunded ideas, for tirelessly writing grants until we were funded, for always encouraging scientific discourse, and for their unfailing support, empathy, and encouragement. I feel that the mark of a great advisor is one who ultimately cares as much, if not more, for the student's development as for the research, and I am thankful to have had this in Sarah and Liz. They will be role models and friends throughout my scientific career. Matt Charette was in many ways a third advisor to me - a deal I'm not sure he bargained for! He graciously (and patiently) offered me his time, expertise, and free reign in his lab. My thesis is much richer as a result of his heavy involvement. I am also grateful to my committee members, Bernhard Peucker-Ehrenbrink, Taylor Perron, Jemma Wadham, and my thesis defense chair, Fiamma Straneo, who all generously donated their time, and always gave me free access to their incredible range of expertise.

One of the best things about WHOI is the access to the amazingly talented scientific and technical staff. I am deeply (deeply) indebted to Krista Longnecker, Crystal Brier, Valier Galy, Melissa Soule, Mark Behn, the NOSAMS prep staff, Phoebe Lam, Meagan Gonneea, Ann McNichol, Sean Sylva, and Scot Birdwhistell. They all generously donated their time and expertise to assist me with analyses, and answer my easy and difficult questions alike. I'm honestly not sure what I would have done without each of them. A special BIG thank you goes out to Paul Henderson, my partner-in-crime in the field and lab. Thank you also to Julia Westwater, Christine Charette, and all the other kind souls in academic programs.

This work would not have been possible without the contributions of my two excellent Greenland field teams. Paul Henderson, Ben Gready, Sarah Das, Elizabeth Kujawinski, Matt Charette, Matt Evans, and Ali Criscitiello all graciously donated their time, filtering abilities, and sheer muscle power to make the foundation of my thesis a success. Additionally, throughout the years, Mark Behn, Ian Joughin, and Kristen Ponair have graciously collected samples for me, despite their inherent geophysist's fear of chemicals.

My MSc advisors at the University of Alberta, Martin Sharp and Julia Foght, have continued to offer their encouragement and support. Indeed, the ideas motivating this thesis first germinated in my MSc, and for that I have Martin and Julia to thank. Martin particularly has generously continued to offer me access to his encyclopedic glaciological mind, office-space in Edmonton, and introduced me to a special field assistant.

I have had the great fortune to have wonderful officemates at WHOI, who became some of my closest friends here. Dave Griffith in the trailer, my marine chemistry p-set partner and research-sounding board. Krista Longnecker in Fye introduced me to MATLAB, and always offered her editing-skills to curtail my tendencies towards verbiage. Without her, this thesis would be 3x longer! I was in Laura Hmelo's office so frequently she may as well have been my officemate. My running and climbing partner, Laura's humour brightened my day in Fye for 4 years. And finally, Evy Mervine, Helen Feng, Andrea Burke, and Emily Roland in Clark, with whom I have been able to finish this wonderful time of my life with. Runs with Andrea, Emily and Erin Bertrand were precious outlets that propelled me to the end. In addition, my JP class cohorts, Carter Esche and Rachel Horwitz, have been wonderful neighbors, and Liz \& Mark, have fed me supper many times, including every Thanksgiving! Finally, Sarah Johnson, a dear friend and one of the most generous souls I know - her friendship and advice were instrumental throughout my degree.

My family and Ben are the rocks that I constantly lean on. This thesis is dedicated to my wonderful, inspirational, loving parents, for their amazing support and encouragement to always chase my interests, to my brother, Amar, and sister-in-law, Meghan, who have unfailingly supported me in everything and tirelessly offered me advice, to Benny, who's humour and perspective have kept me centered and very happy, and to Dr. Hopper, who recently left us, but who's tutelage and faith in me I'll never forget. 
This research was supported the WHOI Arctic Research Initiative (EBK, SBD, MAC), the National Science Foundation (EBK, SBD), NASA (SBD), a National Science and Engineering Research Council of Canada Postgraduate Doctoral Fellowship (MPB), an American Geophysical Union Horton Hydrology Award (MPB), the Ocean Ventures Fund (MPB), and the WHOI Climate Change Institute (MPB). 


\section{Table of Contents}

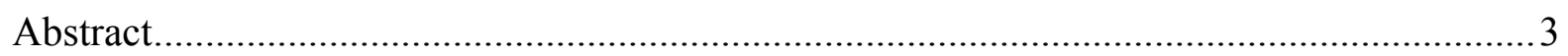

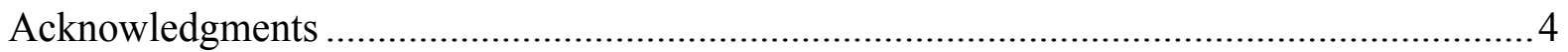

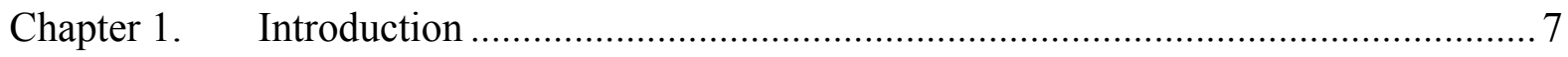

Chapter 2. Seasonal evolution water contributions to discharge from a Greenland outlet glacier: insight from a new isotope-mixing model ................................... 16

Chapter 3. Molecular-level characterization of dissolved organic matter associated with the Greenland ice sheet ................................................................................. 30

Chapter 4. Organic carbon export from the Greenland ice sheet................................ 48

Chapter 5. Iron export from the Greenland ice sheet ............................................. 86

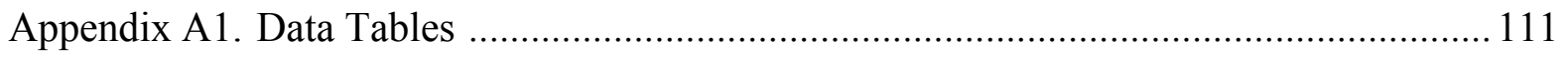

Appendix A2. Supplementary Material for Chapter 3 ................................................. 139 


\section{Chapter 1}

\section{Introduction}

Glaciation is one of the most transformative processes on the Earth's surface, with cycles of glaciation and deglaciation capable of contributing significant quantities of meltwater and associated material to the oceans repeatedly throughout much of Earth's history. Yet, until recently, biogeochemical contributions from glaciers and ice sheets to the oceans were unstudied. Today, the Greenland and Antarctic ice sheets serve as the best analogue for the large Pleistocene ice sheets that covered the continents in the past. Furthermore, global warming has led to a significant increase in Greenland ice sheet (GrIS) melt and runoff since 1990, enhancing export of biogeochemically significant species (e.g. carbon, iron) to the surrounding North Atlantic and Arctic Oceans.

The total GrIS freshwater flux is comprised of surface melt, basal melting, and iceberg calving, and is estimated to be close to $800 \mathrm{~km}^{3} / \mathrm{y}$ (Mernild et al., 2009), with more than half of this contribution coming from surface melting. In 2007, the Greenland ice sheet meltwater runoff contributed an estimated $523 \mathrm{~km}^{3} / \mathrm{y}$, equivalent to the mean annual discharge from the largest river contributors (e.g. Yenisey, Lena, Ob) to the Arctic Ocean (Dittmar and Kattner, 2003). Similar to processes observed on many alpine glaciers, recent evidence indicates that surface meltwater runoff does not take a direct path from the ice sheet surface (supraglacial) to the sea. Instead, a significant quantity drains to the base of the ice sheet (subglacial), via hydrofractures and moulins (vertical englacial channels through a glacier cross-section) (Das et al., 2008). At glacier beds, surface meltwater joins a subglacial system drainage system, where there is potential for substantial interaction with the underlying bedrock and sediments along seasonallyevolving flowpaths (Brown, 2002). Previous work in alpine systems has shown that interaction of glacial meltwaters with subglacial till and bedrock produces discharge with significant chemical enrichment relative to its origin as dilute snow- and ice-melt 
(Brown, 2002; Tranter et al., 2002). Meltwater at the bed also fuels subglacial microbial activities, which facilitate the release of additional nutrients and metals, amplify chemical weathering reactions, and/or utilize the organic carbon present in overridden soils and vegetation (Sharp et al., 1999; Tranter et al., 2005). Recent studies from the Gulf of Alaska have suggested that glacial systems may be capable of supplying old, labile organic matter to coastal marine ecosystems (Hood et al., 2009). Glacier meltwater may also be an important source of limiting nutrients such as nitrogen, phosphorous and trace metals to downstream environments (Hodson et al., 2005; Hood and Scott, 2008; Lafreniere and Sharp, 2005). For example, studies have hinted that glacially-sourced bioavailable iron $(\mathrm{Fe})$ may be a significant input to coastal oceans surrounding Greenland and Antarctica during the height of summer when primary productivity can be Fe-limited (Raiswell et al., 2008; Raiswell et al., 2006; Statham et al., 2008). Thus, the geochemical cycles of elements in the coastal waters surrounding the GrIS may be strongly influenced by the dynamics of meltwater discharge from the ice sheet.

The overarching goal of my $\mathrm{PhD}$ research is to characterize the dynamics of carbon and iron export from the margin of the GrIS to the surrounding North Atlantic Ocean. This region has been subject to an increasing amount of surface melting in the past decade. In this thesis, I use a multi-disciplinary approach to examine the interdependence of glacier hydrology and biogeochemical export from the GrIS. Through a targeted study on a land-terminating outlet glacier system on the southwestern margin of the ice sheet, the questions I explore in Chapters 2-5 are relevant to other outlet glacial systems draining both the Greenland and Antarctic ice sheets. Specifically, I address three questions:

(1) What are the different water sources comprising the meltwater discharge and how do these contributions change throughout a meltseason? 
(2) What is the concentration, age, and composition of the organic carbon stores beneath the GrIS and how does the exported carbon in glacial runoff change throughout a meltseason?

Does meltwater runoff from the Greenland ice sheet contribute a significant flux of labile Fe to the surrounding North Atlantic and Arctic Oceans?

In glacial systems, biogeochemical cycles are intrinsically linked to the structure of the subglacial hydrological system, which dictates the extent of water:rock interaction. In alpine glaciers, subglacial flowpaths seasonally evolve from a delayed-flow (channelized system) to a quick-flow (distributed system) drainage (Paterson, 1994; Richards et al., 1996). However, the seasonal evolution of subglacial drainage is poorly constrained for the GrIS. To address this gap in our knowledge, I developed an isotopemixing model in Chapter 2 to quantify water source contributions to bulk meltwater discharge from a GrIS outlet glacier. Previously, chemical mixing-models in glacial systems were based on bulk parameters, such as electrical conductivity (EC) (Collins, 1979; Gurnell and Fenn, 1984), or individual dissolved ions (e.g. chloride, sulfate) (Brown et al., 1994; Tranter and Raiswell, 1991). However, both of these approaches are hindered by the non-conservative chemical nature of these chemical species under different subglacial conditions. My isotope-mixing model improves upon these past methods by using a combination of conservative stable (oxygen-18, deuterium) and radioactive isotopes (radon-222), illustrating the new application of radon-222 as a quantitative tracer for waters stored at the glacier bed. Results from this work revealed the presence of relatively constant, chemically-enriched delayed flow that becomes progressively diluted with ice-melt throughout the meltseason. This finding is consistent with seasonal subglacial drainage evolution found in alpine systems. Moreover, my model results provide the fundamental hydrological context necessary to interpret and quantify the fluxes of carbon and iron that I focus on for the remainder of my thesis. 
In Chapters 3 and 4, I combine molecular- and bulk-level techniques to comprehensively describe for the first time the organic carbon exported in meltwater runoff from the Greenland ice sheet. Specifically I use: (a) ultra-high resolution mass spectrometry to investigate organic carbon composition and infer potential sources, (b) radiocarbon to infer the age, and (c) dissolved $\mathrm{C} / \mathrm{N}$ ratios to infer the lability. I focus particularly on subglacial organic carbon dynamics and export since our conception of these processes underwent a paradigm shift just over a decade ago, with the revelation that large, active microbial communities are present beneath glaciers (Sharp et al., 1999). This discovery introduced the hypothesis that biological communities are oxidizing the organic carbon stores beneath glaciers, and by extension beneath ice caps and ice sheets. Such a hypothesis has ramifications for global carbon budgets on glacial-interglacial (Sharp et al., 1999) and shorter-term timescales. Approximately $400 \times 10^{15}$ grams of carbon (equivalent to $\sim 25 \%$ of the world's soil organic carbon pool) are presently stored in soils located in regions that were covered by ice during the last glacial maximum (Schlesinger, 1997). Assuming a similar carbon pool was present in these soils during the last interglacial period, then at least some of this carbon was overridden by glaciers and ice sheets during the last glaciation. Microbial utilization (e.g. oxidation/fermentation) of this carbon beneath warm-based sectors of continental ice sheets may have converted some of it to carbon dioxide or methane during the glacial phase of a glacial-interglacial cycle, with considerable impact on carbon budgets for mid-latitude regions (Skidmore et al., 2000). On shorter-term timescales, a couple scenarios exist for the fate of glacially overridden relict organic carbon: (1) the carbon is not utilized, either because it is not bioavailable or there is insufficient subglacial microbial activity, and is simply stored beneath the ice; (2) The carbon is not bioavailable, but is being exported by meltwaters to the marine environment where it is stored (Ohkouchi and Eglinton, 2006); (3) Subglacial microbiota are able to utilize the fossil carbon as a substrate, thus returning to the active global carbon cycle very old organic carbon (Petsch et al., 2001); (4) The relict carbon is bioavailable, but is not entirely consumed by subglacial microbiotia and is exported to and utilized in surrounding marine ecosystems. Discernment of which of these scenarios 
is occurring presently provides insight as to whether organic carbon respiration, storage, or export is most likely to have occurred beneath the continental glaciers during the glacial phase of a glacial-interglacial cycle, and will increasingly occur as the subglacial hydrological system beneath the GrIS expands. Results from this thesis hint that scenario (4) is most likely, and reveal that the Greenland ice sheet exports a unique type of old, labile organic carbon, distinct from riverine export. The organic carbon exported throughout the meltseason is variable and closely linked to the seasonal evolution of subglacial drainage system, which accesses different carbon stores at the ice sheet bed.

Finally, in Chapter 5, I further explore the potential downstream impact of GrIS discharge on oceanic biogeochemical cycles by quantifying the release of iron from Greenland outlet glaciers to surrounding fjords. Iron is an essential micronutrient for phytoplankton growth, thus its availability ultimately has ramifications for regional and global carbon cycling. This chapter provides new insight into dissolved and particulate $\mathrm{Fe}$ concentrations from the GrIS, revealing a potentially significant flux of bioavailable Fe to the North Atlantic ocean in the summer. The labile Fe flux I calculate is on the same order of magnitude as the annual soluble dust flux to the North Atlantic Ocean, a primary source of bioavailable Fe to this ocean (Jickells et al., 2005).

Each chapter in this thesis builds upon the last, to collectively provide a comprehensive view of seasonal biogeochemical cycling and export from ice sheet glacial systems. The hydrology in Chapter 2 is the foundation from which I can determine the annual flux of carbon and iron, and ultimately explain their seasonal variability in glacial runoff rivers. Chapters 3,4 , and 5 then provide more detailed analysis of carbon and iron, key elements in ocean biogeochemical cycles. Glacial biogeochemistry is a new and exploding field of study. This thesis provides some of the first descriptions and estimates of fluxes of biogeochemically significant species (carbon, iron) in ice sheet discharge to surrounding oceans. While the potential contribution of accelerated melt of glaciers, ice caps, and ice sheets to global sea-level rise has been documented (e.g. Box et al., 2006) and is an area of continuing scientific interest (e.g. Joughin et al., 2008; Rignot and Kanagaratnam, 2006) this work reveals that glacier 
discharge also carries a unique biogeochemical signature distinct from other (river, hydrothermal) inputs to the oceans. Ultimately by establishing baseline values of the type and amount of organic carbon and iron present beneath the GrIS, this thesis hopefully serves as a foundation for broader investigations into the impact of glacial meltwater runoff to downstream marine environments in the future and the past. 


\section{References}

Box, J.E., Bromwich, D.H., Veenhuis, B.A., Bai, L.S., Stroeve, J.C., Rogers, J.C., Steffen, K., Haran, T., Wang, S.H., 2006. Greenland ice sheet surface mass balance variability (1988-2004) from calibrated polar MM5 output. Journal of Climate 19, 2783-2800.

Brown, G.H., 2002. Glacier meltwater hydrochemistry. Appl. Geochem. 17, 855-883.

Brown, G.H., Sharp, M.J., Tranter, M., Gurnell, A.M., Nienow, P.W., 1994. Impact of post-mixing chemical reactions on the major ion chemistry of bulk meltwaters draining the Haut Glacier D'Arolla, Valais, Switzerland. Hydrol. Processes 8, 465-480.

Collins, D., 1979. Quantitative determination of the subglacial hydrology of two Alpine glaciers. J. Glaciol. 23, 347-362.

Das, S.B., Joughin, I., Behn, M.D., Howat, I.M., King, M.A., Lizarralde, D., Bhatia, M.P., 2008. Fracture propagation to the base of the Greenland Ice Sheet during supraglacial lake drainage. Science 320, 778-781.

Dittmar, T., Kattner, G., 2003. The biogeochemistry of the river and shelf ecosystem of the Arctic Ocean: a review. Mar. Chem. 83, 103-120.

Gurnell, A., Fenn, C., 1984. Flow separation, sediment source areas and suspended sediment transport in a proglacial stream Catena Supplement 5, 109-119.

Hodson, A.J., Mumford, P.N., Kohler, J., Wynn, P.M., 2005. The High Arctic glacial ecosystem: new insights from nutrient budgets. Biogeochemistry 72, 233-256.

Hood, E., Fellman, J., Spencer, R.G.M., Hernes, P.J., Edwards, R., D'Amore, D., Scott, D., 2009. Glaciers as a source of ancient and labile organic matter to the marine environment. Nature 462, 1044-U1100.

Hood, E., Scott, D., 2008. Riverine organic matter and nutrients in southeast Alaska affected by glacial coverage. Nat. Geosci. 1, 583-587.

Jickells, T.D., An, Z.S., Andersen, K.K., Baker, A.R., Bergametti, G., Brooks, N., Cao, J.J., Boyd, P.W., Duce, R.A., Hunter, K.A., Kawahata, H., Kubilay, N., laRoche, J., Liss, P.S., Mahowald, N., Prospero, J.M., Ridgwell, A.J., Tegen, I., Torres, R., 2005. Global iron connections between desert dust, ocean biogeochemistry, and climate. Science 308, 67-71. 
Joughin, I., Das, S.B., King, M.A., Smith, B.E., Howat, I.M., Moon, T., 2008. Seasonal speedup along the western flank of the Greenland Ice Sheet. Science 320, 781783.

Lafreniere, M.J., Sharp, M.J., 2005. A comparison of solute fluxes and sources from glacial and non-glacial catchments over contrasting melt seasons. Hydrol. Processes 19, 2991-3012.

Mernild, S.H., Liston, G.E., Hiemstra, C.A., Steffen, K., Hanna, E., Christensen, J.H., 2009. Greenland Ice Sheet surface mass-balance modelling and freshwater flux for 2007, and in a 1995-2007 perspective. Hydrol. Processes 23, 2470-2484.

Ohkouchi, N., Eglinton, T.I., 2006. Radiocarbon constraint on relict organic carbon contributions to Ross Sea sediments. Geochem. Geophys. Geosyst. 7.

Paterson, W., 1994. The Physics of Glaciers, 3rd ed. Butterworth-Heinemann, Oxford, $\mathrm{UK}$.

Petsch, S.T., Eglinton, T.I., Edwards, K.J., 2001. C-14-dead living biomass: Evidence for microbial assimilation of ancient organic carbon during share weathering. Science $292,1127-1131$.

Raiswell, R., Benning, L.G., Tranter, M., Tulaczyk, S., 2008. Bioavailable iron in the Southern Ocean: the significance of the iceberg conveyor belt. Geochem. Trans. 9.

Raiswell, R., Tranter, M., Benning, L.G., Siegert, M., De'ath, R., Huybrechts, P., Payne, T., 2006. Contributions from glacially derived sediment to the global iron (oxyhydr)oxide cycle: Implications for iron delivery to the oceans. Geochim. Cosmochim. Acta 70, 2765-2780.

Richards, K., Sharp, M., Arnold, N., Gurnell, A., Clark, M., Tranter, M., Nienow, P., Brown, G., Willis, I., Lawson, W., 1996. An integrated approach to modelling hydrology and water quality in glacierized catchments. Hydrol. Processes 10, 479-508.

Rignot, E., Kanagaratnam, P., 2006. Changes in the Velocity Structure of the Greenland Ice Sheet. Science 311, 986-990.

Schlesinger, W., 1997. Biogeochemistry: An analysis of global change, 2nd ed. Academic Press, Boston, MA. 
Sharp, M., Parkes, J., Cragg, B., Fairchild, I.J., Lamb, H., Tranter, M., 1999. Widespread bacterial populations at glacier beds and their relationship to rock weathering and carbon cycling. Geology 27, 107-110.

Skidmore, M.L., Foght, J.M., Sharp, M.J., 2000. Microbial life beneath a high Arctic glacier. Appl. Environ. Microbiol. 66, 3214-3220.

Statham, P.J., Skidmore, M., Tranter, M., 2008. Inputs of glacially derived dissolved and colloidal iron to the coastal ocean and implications for primary productivity. Global Biogeochem. Cycles 22.

Tranter, M., Raiswell, R., 1991. The composition of the englacial and subglacial component in bulk meltwaters draining the Gornergletscher, Switzerland. J. Glaciol. 37, 59-66.

Tranter, M., Sharp, M.J., Lamb, H.R., Brown, G.H., Hubbard, B.P., Willis, I.C., 2002. Geochemical weathering at the bed of Haut Glacier d'Arolla, Switzerland - a new model. Hydrol. Processes 16, 959-993.

Tranter, M., Skidmore, M., Wadham, J., 2005. Hydrological controls on microbial communities in subglacial environments. Hydrol. Processes 19, 995-998. 


\title{
Chapter 2
}

\author{
Seasonal evolution water contributions to discharge from a Greenland outlet \\ glacier: insight from a new isotope-mixing model *
}

\begin{abstract}
The Greenland ice sheet (GrIS) subglacial hydrological system may undergo a seasonal evolution, with significant geophysical and biogeochemical implications. We present results from a new isotope mixing model to quantify the relative contributions of surface snow, glacial ice, and delayed flow to the bulk meltwater discharge from a small ( $\sim 5-$ $\mathrm{km}^{2}$ ) land-terminating GrIS outlet glacier during melt onset (May) and at peak melt (July). We use radioactive (radon-222) and stable isotopes (oxygen-18, deuterium) to differentiate the source-water contributions. Atmospherically-derived beryllium-7 further constrains meltwater transit time from the glacier surface to the ice margin. We show that (i) radon-222 is a promising tracer for glacial waters stored at the bed and (ii) a quantitative chemical mixing model can be constructed by combining radon-222 and the stable water isotopes. Applying this model to the bulk subglacial outflow from our study area, we find a constant delayed flow (stored) component from melt onset through peak melt. This component is diluted first by snow-melt and then by increasing glacial ice-melt as the season progresses. Results from this pilot study are consistent with the hypothesis that subglacial drainage beneath land-terminating sections of the GrIS undergoes a seasonal evolution from a distributed system to a channelized one.
\end{abstract}

* Published as: Bhatia, M., S.B. Das, E.B. Kujawinski, P. Henderson, A. Burke, and M.A. Charette (2011). Seasonal evolution water contributions to discharge from a Greenland outlet glacier: insight from a new isotope-mixing model, Journal of Glaciology, 57(205): 929-940. 


\title{
Seasonal evolution of water contributions to discharge from a Greenland outlet glacier: insight from a new isotope-mixing model
}

\author{
Maya P. BHATIA, ${ }^{1}$ Sarah B. DAS, ${ }^{2}$ Elizabeth B. KUJAWINSKI, ${ }^{3}$ Paul HENDERSON, ${ }^{3}$ \\ Andrea BURKE, ${ }^{1}$ Matthew A. CHARETTE ${ }^{3}$ \\ ${ }^{1}$ MITMHOI Joint Program in Oceanography/Applied Ocean Sciences and Engineering, Department of Geology and \\ Geophysics, Woods Hole Oceanographic Institution, Woods Hole, Massachusetts 02543, USA \\ E-mail: mayab@mit.edu \\ ${ }^{2}$ Department of Geology and Geophysics, Woods Hole Oceanographic Institution, Woods Hole, Massachusetts 02543, USA \\ ${ }^{3}$ Department of Marine Chemistry and Geochemistry, Woods Hole Oceanographic Institution, Woods Hole, \\ Massachusetts 02543, USA
}

\begin{abstract}
The Greenland ice sheet (GrIS) subglacial hydrological system may undergo a seasonal evolution, with significant geophysical and biogeochemical implications. We present results from a new isotope-mixing model to quantify the relative contributions of surface snow, glacial ice and delayed flow to the bulk meltwater discharge from a small $\left(\sim 5 \mathrm{~km}^{2}\right)$ land-terminating GrIS outlet glacier during melt onset (May) and at peak melt (July). We use radioactive $\left({ }^{222} \mathrm{Rn}\right)$ and stable isotopes $\left({ }^{18} \mathrm{O}\right.$, deuterium) to differentiate the water source contributions. Atmospherically derived ${ }^{7} \mathrm{Be}$ further constrains meltwater transit time from the glacier surface to the ice margin. We show that $(1){ }^{222} \mathrm{Rn}$ is a promising tracer for glacial waters stored at the bed and (2) a quantitative chemical mixing model can be constructed by combining ${ }^{222} \mathrm{Rn}$ and the stable water isotopes. Applying this model to the bulk subglacial outflow from our study area, we find a constant delayed-flow (stored) component from melt onset through peak melt. This component is diluted first by snowmelt and then by increasing glacial ice melt as the season progresses. Results from this pilot study are consistent with the hypothesis that subglacial drainage beneath land-terminating sections of the GrIS undergoes a seasonal evolution from a distributed to a channelized system.
\end{abstract}

\section{INTRODUCTION}

The Greenland ice sheet (GrIS) contributes significant quantities of meltwater to the surrounding North Atlantic and Arctic Oceans (Solomon and others, 2007). During the high-melt year of 2007, for example, the GrlS contributed an estimated $523 \mathrm{~km}^{3} \mathrm{a}^{-1}$ surface runoff (Mernild and others, 2009), equivalent to the combined mean annual discharge from the four large North American pan-Arctic rivers, Yukon, Mackenzie, Peel and Beck (Shiklomanov, 2009). Recent evidence that a large fraction of annual surface meltwater likely drains to the bed of the GrIS (McMillan and others, 2007; Das and others, 2008; Krawczynski and others, 2009) suggests that significant portions of the GrlS subglacial hydrological system may undergo a seasonal evolution, akin to those observed beneath alpine glaciers (Shepherd and others, 2009; Bartholomew and others, 2010). This routing suggests there is potential for substantial meltwater interaction with underlying subglacial till and bedrock along seasonally evolving flow paths. Despite recent interest in the GrIS subglacial hydrological system (Box and Ski, 2007; Joughin and others, 2008; Shepherd and others, 2009; Bartholomew and others, 2010; Tsai and Rice, 2010), understanding of the subglacial drainage seasonal evolution remains limited and poorly constrained.

In alpine glacial systems, subglacial flow paths can vary seasonally between two end-member systems: channelized drainage (quick flow) and distributed drainage (delayed flow) (Paterson, 1994). Channelized drainage systems are a series of large tunnels incised into the bedrock, the overlying ice or the till, which facilitate localized and rapid water flow $\left(\sim 1 \mathrm{~m} \mathrm{~s}^{-1}\right)$ to the glacier front. They are prevalent at the peak of the summer melt season (Paterson, 1994; Benn and Evans, 1998) and transport the bulk of surface ice melt that has drained to the bed (Richards and others, 1996; Nienow and others, 1998). In comparison, distributed drainage systems, envisioned as a series of linked cavities, lie along the ice/bed interface, and may include a constant source of water from basal ice melt and groundwater in contact with glacial till (Paterson, 1994). Such systems have characteristically slower water transit times $\left(\sim 0.01 \mathrm{~m} \mathrm{~s}^{-1}\right)$, higher water pressures and are water-full for most of the year (Richards and others, 1996; Benn and Evans, 1998). Additionally, they may transport a significant proportion of early-season snowmelt to the glacier front (Nienow and others, 1998).

The seasonal evolution of subglacial drainage conditions has important geophysical and biogeochemical implications. From a geophysical perspective, the partitioning of meltwater between these two different drainage systems strongly influences basal water pressures and thus sliding velocities (Paterson, 1994). From a biogeochemical perspective, the degree of water/rock contact dictates the chemical enrichment of discharge waters exported to surrounding marine ecosystems, and may fuel subglacial microbial processes (Sharp and others, 1999; Skidmore and others, 2000). Microbial communities could in turn facilitate the release of additional nutrients and metals, amplify chemical weathering reactions and/or utilize previously overridden organic carbon (Tranter and others, 2002; Wadham and others, 2008; Bhatia and others, 2010). Thus, the geochemical cycles of major and minor elements in the coastal waters surrounding the GrIS may be strongly influenced by the temporal dynamics of subglacial discharge (as observed 
in other regions: Raiswell and others, 2006; Hood and Scott, 2008; Hood and others, 2009), and in particular by the release of water that has been stored at the bed.

The development of a chemical mixing model that can successfully differentiate water source contributions and subglacial flow paths will complement existing geophysical and active-tracer methods used to study seasonally evolving subglacial hydrological systems (Nienow and others, 1998; Bartholomew and others, 2010). The interaction of surface meltwater with the glacier bed alters its chemical composition from dilute snow- and ice melt to chemically enriched subglacial discharge waters. Thus, in theory, variations in solute concentrations could be used to infer the evolution of the subglacial drainage network by differentiating water source contributions. This approach is promising because distributed drainage systems produce discharge waters with significantly enriched chemical signatures due to the longer residence time at the bed compared to channelized drainage systems. Initial mixingmodel efforts based the separation of discharge components on bulk properties such as electrical conductivity (EC) (Collins, 1979; Gurnell and Fenn, 1984). However, a model with EC as its defining chemical parameter is poorly constrained because EC is not conservative in glacial systems, and is subject to temporal variations in chemical signature and to post-mixing solute acquisition (Sharp and others, 1995). Consequently, individual dissolved species (e.g. sulfate, chloride) whose provenance is exclusive to specific discharge components have been increasingly used instead of EC (Tranter and Raiswell, 1991; Brown and others, 1994; Tranter and others, 1997; Mitchell and others, 2001). Despite this progress, discharge component separations remain challenging because individual solutes may not retain unique signatures over time and may be involved in subglacial biological reactions across glacial catchments (Sharp and others, 1995; Brown, 2002). Thus, the potential of hydrochemical separation methods in glacier systems has yet to be fully realized (Sharp and others, 1995; Brown, 2002).

Here we introduce a new multi-component isotopemixing model combining the radioactive isotope radon-222 $\left({ }^{222} \mathrm{Rn}\right)$ with the stable water isotopes oxygen-18 $\left({ }^{18} \mathrm{O}\right)$ and deuterium (D) as passive flow tracers. These natural isotopic tracers have unique end-member signatures for different reservoirs ultimately contributing to the total glacial outflow, and are not subject to additional post-mixing enrichment or alteration. We then apply this model to quantify the relative contributions of different water reservoirs to the bulk meltwater discharge at a small landterminating outlet glacier along the western margin of the GrIS in three stages: (1) identified conceptual end-member water reservoirs (surface snow, glacial ice and delayed flow), (2) identified unique passive flow isotopic tracers for each water reservoir $\left(\delta^{18} \mathrm{O}, \mathrm{D}\right.$ and $\left.{ }^{222} \mathrm{Rn}\right)$, and (3) applied end-member mixing analysis to estimate relative contributions of each conceptual water reservoir. We limit our separation to these three conceptual reservoirs because hydrographic separation of all potential drainage components is not possible without additional isotopes or endmember analyses. Finally, we investigate the potential for using beryllium-7 $\left({ }^{7} \mathrm{Be}\right)$, a naturally occurring radioisotope produced in the atmosphere, as a tracer for the transit of snowmelt through the subglacial drainage system. To our knowledge, this is the first time that beryllium has been used in a glacial system as a tracer of hydrological flow.
Through the application of radioisotopes, this pilot study represents a new direction in the use of chemical mixing models to delineate subglacial drainage structure, even though full hydrograph separation of all potential drainage components remains elusive.

\section{MODEL THEORY}

The basic tenets of radon radiochemistry suggest that it has the potential to be an effective tracer of delayed-flow basal waters characteristic of distributed subglacial drainage systems. Radon, an inert noble gas, is a daughter product of radium-226 within the uranium-238 decay series that is naturally present in soil, sediment and rocks. Since the uranium content of solids and the degree of water/rock interaction will determine the amount of radon enrichment in a given water parcel, groundwater will be highly enriched in radon, as should any surface meltwater or basal ice melt that has been stored subglacially. In contrast, surface snowmelt and glacial ice melt that is quickly routed through the subglacial environment has minimal lithogenic sediment contact, and so should be relatively devoid of radon. Radon has been successfully applied as a tracer of submarine groundwater discharge (Cable and others, 1996; Corbett and others, 1997; Burnett and Dulaiova, 2003) but has only recently been applied in a glacial setting (Kies and others, 2010). Moreover, the high uranium content of the Greenland fractured silicate bedrock suggests that waters in contact with the GrIS subglacial environment will be particularly enriched in radon (Kraemer and Genereux, 1998)

Our new model is also based on the hypothesis that the surface snow and glacial ice at a GrIS outlet glacier have unique $\delta^{18} \mathrm{O}$ and $\delta \mathrm{D}$ signatures. Stable water isotopes have been used extensively in glacial settings for a variety of applications from ice-core paleotemperature reconstructions (e.g. Jouzel and others, 1997) to delineation of drainage basins on the GrlS (Reeh and Thomsen, 1993). The GrIS margin, in contrast to alpine catchments (Theakstone, 2003), possesses large isotopic differences between snow and ice components (e.g. Reeh and Thomsen, 1993). This is because seasonal surface snow carries the enriched signature of present-day precipitation at relatively high temperatures and low elevation across the ablation zone, whereas underlying marginal glacial ice will have comparatively more depleted values, reflecting its depositional and flow history from higher elevations and/or colder times (Dansgaard and others, 1971).

\section{FIELD SITE AND SAMPLING OVERVIEW}

Sampling for this study was conducted at two primary field locations along the GrIS southwestern margin. Samples were collected in 2008 in the vicinity of a small $\left(\sim 5 \mathrm{~km}^{2}\right.$; see Section 3.3 for more details) land-terminating outlet glacier $125 \mathrm{~km}$ south of Jakobshavn Isbræ ( $\mathrm{N}^{\prime}$ glacier; $68^{\circ} 02^{\prime} 34^{\prime \prime} \mathrm{N}$, $50^{\circ} 16^{\prime} 08^{\prime \prime} \mathrm{W}$ ), with a surface elevation range from $\sim 100$ to $\sim 500 \mathrm{~m}$ (Fig. 1a and b). Supraglacial samples were collected from surface snow and a meltwater pond on the surface of ' $\mathrm{N}$ ' glacier (Fig. 1C), and glacial ice samples at the margin of the glacier; subglacial samples were collected from the outflow stream (Fig. 1d) exiting the base of the glacier at two locations: the mouth where the outflow first emerged, and a downstream site $\sim 0.15 \mathrm{~km}$ from the outflow mouth. 

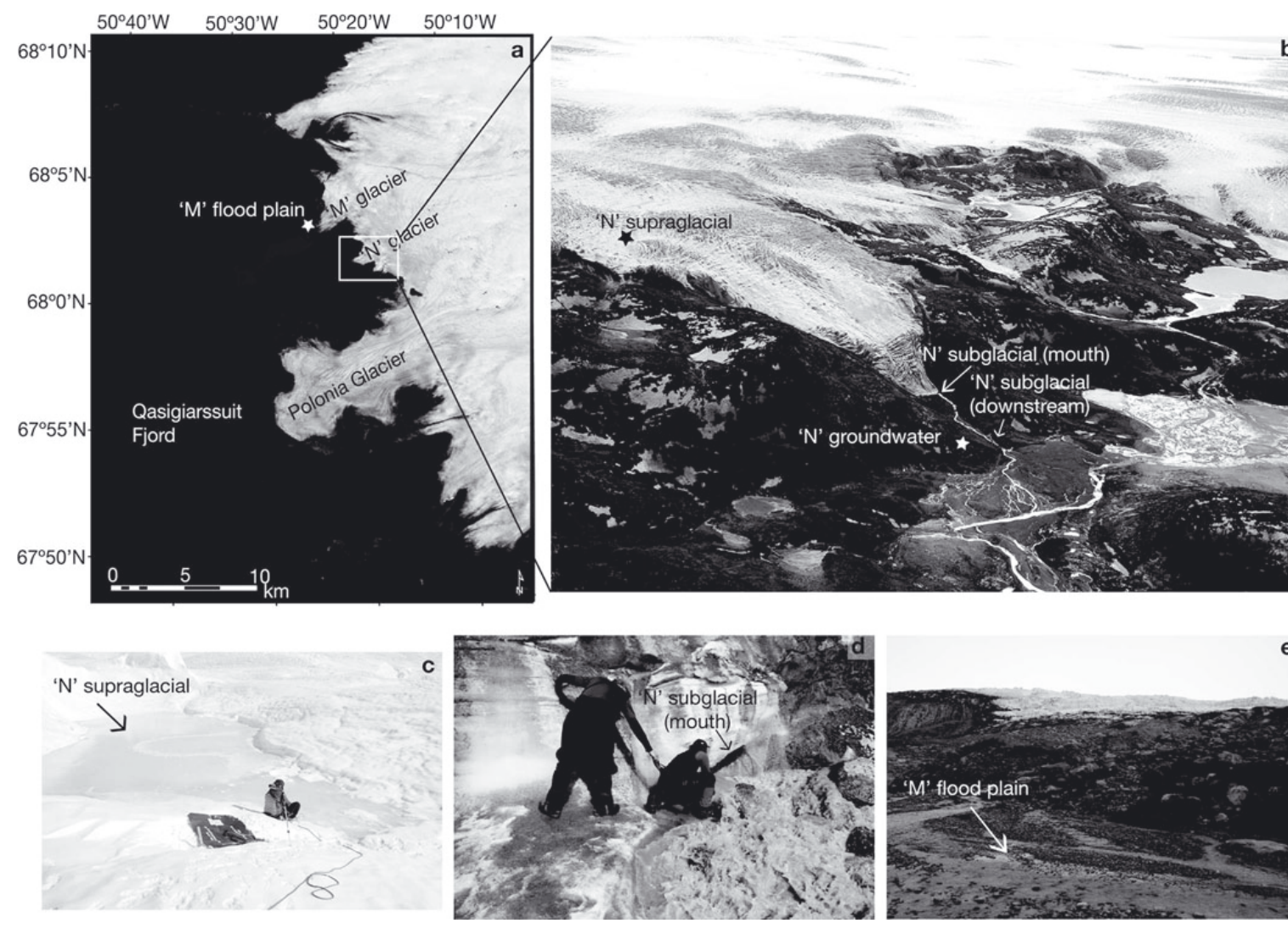

Fig. 1. (a) Landsat image of the 2008 ice-margin field site. Sampling was concentrated at ' $N$ ' glacier and on the ' $M$ ' flood plain. (b) Air photo of the land-terminating outlet glacier (' $N$ ' glacier) focused upon in this study, with specific sample sites labeled. (c) Photo of the supraglacial pond sampled on the surface of ' $\mathrm{N}$ ' glacier. (d) Photo of the mouth of the ' $\mathrm{N}$ ' glacier outflow stream. (e) Photo of the ' $\mathrm{M}$ ' flood-plain sample site.

Groundwater samples were taken from the bank of the ' $\mathrm{N}$ ' glacier proglacial stream and the flood plain of an adjacent larger glacier ('M' glacier) (Fig. 1e). Most samples were acquired while field personnel were on-site in late spring (16 May-1 June) and at the height of the summer melt season (10-17 July); automated instrumentation was used to measure and/or sample selected parameters between 2 June and 15 July. Constraints on end-member values were supplemented with supraglacial snow, ice and meltwater samples collected in July 2007 and 2008 within the ablation zone (980 m elevation) $70 \mathrm{~km}$ north of the primary study site $\left(68^{\circ} 34^{\prime} 16^{\prime \prime} \mathrm{N}, 49^{\circ} 21^{\prime} 29^{\prime \prime} \mathrm{W}\right)$.

\subsection{Meteorological measurements}

Local meteorological conditions were obtained using a HOBO U30-NRC weather station equipped with a tippingbucket rain gauge and data logger installed at $100 \mathrm{~m}$ elevation and $\sim 1.5 \mathrm{~m}$ above the ground in the proglacial area in the vicinity of ' $\mathrm{N}$ ' glacier. Shielded air temperatures and precipitation $(0.2 \mathrm{~mm}$ resolution) were recorded every $5 \mathrm{~min}$ for the duration of the 2008 field season (16 May17 July) with some gaps ( $73 \mathrm{~min}$ on day $138,7 \mathrm{~min}$ on day 146 , and 72.45 hours from day 151 to day 154). Hourly and daily moving averages were calculated for temperature, and daily total values were summed for precipitation. All times are reported in Greenland local time (GMT $-3 \mathrm{~h}$ ).

\subsection{Discharge measurements}

Stream discharge was measured at the ' $\mathrm{N}$ ' glacier outflow stream using the velocity-area method and pressure transducers (HOBO U20 Water Level Logger and InSitu Level TROLL 300 Logger) at a location $\sim 0.15 \mathrm{~km}$ downstream of the glacier mouth. Stream velocities were measured using a manual flowmeter (General Oceanics Mechanical Flow-meter, model 2030R). A horizontal transect was established across the stream, and triplicate velocity measurements were taken at evenly spaced subsections (verticals) along the stream transect. The triplicate measurements were averaged to produce a single velocity at each vertical. Discharges for each stream subsection were calculated as the product of the subsection velocity and area (Dingman, 2002) and summed to obtain a total stream discharge $\left(\mathrm{m}^{3} \mathrm{~s}^{-1}\right)$. Pressure transducers were used to continuously measure stream stage (depth). Water pressure was sensed in $10 \mathrm{~min}$ intervals from 31 May (19:00) to 16 July, and was converted to stream stage after correction for atmospheric pressure using a record sensed by an InSitu BaroTROLL Logger. A stage-discharge rating curve $\left(r^{2}=0.76, p<0.01\right)$ was developed using 12 discharge measurements. The rating curve was used to produce a continuous discharge record for the period with continuous stage measurements with point discharges only available from 19 to 27 May. Total meltwater discharge measured 
from ' $N$ ' glacier between 31 May and 16 July is $6.4 \times 10^{6} \mathrm{~m}^{3}$. The error associated with the discharge is estimated to be $\pm 7 \%$ (following Dingman, 2002).

\subsection{Catchment delineation}

Lacking adequately resolved ice thickness and surface and basal topography for this region, we rely on interferometric synthetic aperture radar (InSAR)-derived ice velocity (personal communication from I. Joughin, 2011) to delineate the ' $N$ ' glacier surface area. We defined the catchment area at the downstream end to be bounded by the margins of the outlet glacier at the ice-sheet edge. We delimited the top of the catchment area where the background ice-sheet flow diverged from ' $N$ ' glacier. We were further limited in this approach by the coarse resolution $(500 \mathrm{~m})$ of the InSAR, so we defined divergence as separation of streamlines by one or more grid spacings. Using this method, we estimate the glacier length to be $5 \mathrm{~km}$ and the surface area to be $5 \mathrm{~km}^{2}$, which we defined as the catchment area for the purposes of evaluating surface meltwater input. To evaluate the reasonableness of this estimate, we calculated the total surface melt over this area required to match the cumulative discharge measured at the front of ' $\mathrm{N}$ ' glacier. This calculation yielded a mean melt rate of $\sim 0.03 \mathrm{~m} \mathrm{~d}^{-1}$ (i.e. $1.28 \mathrm{~m} / 46$ days), a value well within the range of summer melt rates previously reported for the western margin of the GrIS (Box and others, 2006), thus providing an independent assessment of our catchment area.

\section{END-MEMBER WATER RESERVOIRS AND ISOTOPE MEASUREMENTS}

Three conceptual end-member water reservoirs contributing to the bulk subglacial discharge from ' $\mathrm{N}$ ' glacier were defined: (1) surface snow, (2) glacier ice and (3) delayed flow, where surface snow and glacier ice represent water sources, and delayed flow is a hydrological flow path. Samples were collected from the bulk discharge as well as each end-member (where possible) across the catchment. Samples were then analyzed for $\delta^{18} \mathrm{O}, \delta \mathrm{D},{ }^{222} \mathrm{Rn}$ and ${ }^{7} \mathrm{Be}$. In this study, delayed flow is operationally defined as water stored at the base on a timescale of days to weeks. These waters could consist of supraglacial waters stored at the base, basal-ice melt and groundwater. The timescale is dictated by the time required for radon $\left(\tau^{1 / 2}=3.8\right.$ days $)$ to approach secular equilibrium activity with its parent radium226. At this activity, the production rate of radon is equal to its decay rate, and the radon content of waters stored at the bed is constant.

\subsection{Stable water isotopes}

Both seasonal-snow and glacial-ice $\delta^{18} \mathrm{O}$ and $\delta \mathrm{D}$ values vary with surface elevation, so samples were collected from this study to constrain these values. Samples include measurements from surface snow $(\sim 300 \mathrm{~m}$ elevation), glacial ice ( $\sim 100, \sim 300$ and $\sim 1000 \mathrm{~m}$ elevation), groundwater ( $\sim 100 \mathrm{~m}$ elevation) and basal ice ( $\sim 100 \mathrm{~m}$ elevation). We then estimated the range of expected $\delta^{18} \mathrm{O}$ values over the ' $\mathrm{N}$ ' glacier catchment (100-500 m surface elevation). Snow $\delta^{18} \mathrm{O}$ values were estimated using a $0.5 \%$ depletion per $100 \mathrm{~m}$ rise in elevation to account for the effect of altitude on $\delta^{18} \mathrm{O}$ (Clark and Fritz, 1997). Glacial ice $\delta^{18} \mathrm{O}$ values were estimated using an empirical relationship defined by Reeh and Thomsen (1993) at a nearby GrlS location. The average difference $\left(+2.5 \%\right.$ ) between the measured ice $\delta^{18} \mathrm{O}$ at both 100 and $300 \mathrm{~m}$ and that calculated using the relationship defined by Reeh and Thomsen (1993) was used to correct the calculated $\delta^{18} \mathrm{O}$ ice value at $500 \mathrm{~m}$. Bulk discharge samples for $\delta^{18} \mathrm{O}$ and $\delta \mathrm{D}$ measurements from the ' $\mathrm{N}$ ' glacier outflow stream mouth and downstream sites were also collected. The discharge samples were collected at least daily from 18 May to 1 June and 10 to 16 July. Between 2 June and 9 July an ISCO 3700 autosampler (Teledyne Isco Inc.) was used to collect samples in intervals ranging from 1.5 to 4.5 days.

All samples were collected in acid-cleaned and samplerinsed 250 or $1000 \mathrm{~mL}$ polypropylene bottles from which two $10 \mathrm{~mL}$ aliquots were taken for $\delta^{18} \mathrm{O}$ and $\delta \mathrm{D}$ analysis. Samples were frozen upon return to the laboratory until analysis. Thawed water samples were analyzed for $\delta^{18} \mathrm{O}$ and $\delta \mathrm{D}$ at the University of California Davis Stable Isotope Facility on a Laser Water Isotope Analyzer V2 (Los Gatos Research, Inc., Mountain View, CA, USA) with precisions of $\leq 0.3 \%$ for $\delta^{18} \mathrm{O}$ and $\leq 0.8 \%$ for $\delta \mathrm{D}$.

\subsection{Radon-222}

Water samples were collected for end-member ${ }^{222} \mathrm{Rn}$ activity from a supraglacial meltwater pond near the edge of ' $\mathrm{N}$ ' glacier (22 and 31 May), from groundwater along the stream bank $0.15 \mathrm{~km}$ from the mouth of ' $\mathrm{N}$ ' glacier (25 May) and from groundwater in the flood plain of ' $\mathrm{M}$ ' glacier (28 May). Groundwater samples were taken at $\sim 0.4 \mathrm{~m}$ depth, using a stainless-steel drive point piezometer. Daily ' $\mathrm{N}$ ' glacier outflow samples were collected on 18, 21-23, 27 and 29-31 May and 10-16 July from the mouth of ' $\mathrm{N}$ ' glacier. Higher-resolution time-series samples (6 hour intervals) were taken on 31 May and 12 July. EC was also measured on-site using a Russell RF060C meter (Thermo Electron). Radon-222 samples were collected without headspace in glass $250 \mathrm{~mL}$ bottles, and were quantified using a RAD-7 continuous radon monitor (Durridge Inc.) (Burnett and Dulaiova, 2003). Typical RAD-7 uncertainties were $14 \%$, with a range of $8-37 \%$ for the lowest measured ${ }^{222} \mathrm{Rn}$ activities in this study. All samples were analyzed within 24 hours of collection. Results were corrected for radioactive decay between the time of collection and analysis and reported as an activity in disintegrations per minute per liter $\left(\mathrm{dpm} \mathrm{L}{ }^{-1}\right)$. A model II (geometric mean) regression was used to compare the radon and EC data since both are measured (dependent) parameters with different units (Ricker, 1973; Sofal and Rohlf, 1995).

In order to determine the maximum potential radon activities in saturated subglacial sediments, laboratory equilibration experiments were conducted using sediment collected from the proglacial area at the mouth of the ' $N$ ' glacier outflow $(n=1)$ and downstream $(n=2)$. Approximately $100 \mathrm{~g}$ of wet sediment were incubated with $\sim 0.5 \mathrm{~L}$ radium-free water in sealed $1 \mathrm{~L}$ high-density polyethelyene bottles, following methods described by Dulaiova and others (2008). The sediment was incubated for at least 3 weeks and the radon was subsequently quantified via an alpha scintillation technique. Each sediment equilibration sample was analyzed twice. The measured radon activities $\left(\mathrm{dpm} \mathrm{g}^{-1}\right)$ in the wet sediment were converted to pore-water radon activities $\left(\mathrm{dpm} \mathrm{L}^{-1}\right)$ using a wet bulk density of $2.3 \mathrm{~g} \mathrm{~cm}^{-3}$ and a porosity of 0.2 (Dulaiova and others, 2008). 
Table 1. Isotope tracer values used to initially solve the endmember mixing model equations (Equations (1-4)). For the delayedflow waters a basal ice sample collected at $100 \mathrm{~m}$ elevation was used for the $\delta^{18} \mathrm{O}$ and $\delta \mathrm{D}$ ratios, while the maximum ' $\mathrm{N}$ ' glacier outflow radon activity was used as the ${ }^{222} \mathrm{Rn}$ end-member. The radon activity of the surface snow and glacial ice reservoirs was set to zero

\begin{tabular}{lcccc}
\hline Water source & $\begin{array}{c}\text { Elevation } \\
\mathrm{m}\end{array}$ & $\begin{array}{c}\delta^{18} \mathrm{O} \\
\% 0\end{array}$ & $\begin{array}{c}\delta \mathrm{D} \\
\% 0\end{array}$ & $\begin{array}{c}{ }^{222} \mathrm{Rn} \\
\mathrm{dpm} \mathrm{L} \mathrm{L}^{-1}\end{array}$ \\
\hline Surface snow & 300 & -12.3 & -89.9 & 0 \\
Glacial ice & 300 & -28.2 & -216.1 & 0 \\
Delayed-flow waters & 100 & -29.6 & -227.2 & 209.5 \\
\hline
\end{tabular}

\subsection{Beryllium-7}

Water samples $(\sim 190 \mathrm{~L})$ for measuring ${ }^{7}$ Be activity were collected from a supraglacial meltwater pond near the edge of ' $\mathrm{N}$ ' glacier (22 May) and from a supraglacial meltwater stream at the inland ice-sheet site (20 July). Two ' $\mathrm{N}$ ' glacier discharge samples were collected for ${ }^{7} \mathrm{Be}$ (21 May and 11 July). Water was collected in a large plastic container and processed on-site. The supraglacial samples were not filtered prior to collection due to the lack of particles in these waters; however, the ' $N$ ' glacier outflow stream sample was filtered through a $10 \mu \mathrm{m}$ Hytrex II cartridge prior to collection. A $1 \mathrm{~mL}$ aliquot of stable ${ }^{9} \mathrm{Be}(10000 \mathrm{ppm})$ was added as a yield monitor, and iron oxide $\left(\mathrm{Fe}(\mathrm{OH})_{3}\right)$ fibers were used to pre-concentrate both the ${ }^{7} \mathrm{Be}$ and ${ }^{9} \mathrm{Be}$ from the water sample (Andrews and others, 2008). Periodic aliquots $(20 \mathrm{~mL})$ of the fiber column filtrate were taken and subsequently analyzed on an inductively coupled plasma mass spectrometer (ICP-MS) at the Woods Hole Oceanographic Institution (WHOI) to determine the collection efficiencies for ${ }^{7} \mathrm{Be}$ (Andrews and others, 2008). The fibers were combusted at $820^{\circ} \mathrm{C}$ for 16 hours and the ash was analyzed for ${ }^{7} \mathrm{Be}$ via gamma spectroscopy (Andrews and others, 2008). Samples were counted for 2 days, and corrected for decay since the time of collection. Beryllium recovery on the fibers averaged $75 \%$. Results are presented as activities in units of $d p \mathrm{~m} \mathrm{~L}^{-1}$.

\section{MODEL DESCRIPTIONS}

\subsection{Isotope-mixing model}

A multi-component isotope-mixing model using the stable water isotope values and radon measurements described above was constructed to quantify the relative fraction of flow contributed by each end-member water source to the total discharge exiting ' $N$ ' glacier using

$$
\begin{gathered}
\text { Mass conservation: } f_{1}+f_{2}+f_{3}+f_{4}=1 \\
\delta^{18} \mathrm{O}: f_{1} \delta^{18} \mathrm{O}_{1}+f_{2} \delta^{18} \mathrm{O}_{2}+f_{3} \delta^{18} \mathrm{O}_{3}=\delta^{18} \mathrm{O}_{4} \\
\delta \mathrm{D}: f_{1} \delta \mathrm{D}_{1}+f_{2} \delta \mathrm{D}_{2}+f_{3} \delta \mathrm{D}_{3}=\delta \mathrm{D}_{4} \\
{ }^{222} \mathrm{Rn}: f_{1}{ }^{222} \mathrm{Rn}_{1}+f_{2}{ }^{222} \mathrm{Rn}_{2}+f_{3}{ }^{222} \mathrm{Rn}_{3}={ }^{222} \mathrm{Rn}_{4},
\end{gathered}
$$

where $f$ is the fraction of flow and subscripts indicate the following: 1 is the snow end-member, 2 is the glacial ice end-member, 3 is the delayed-flow end-member and 4 is the ' $N$ ' glacier outflow. The end-member water source and ' $N$ '
Table 2. Range of isotope tracer values used in end-member mixing model sensitivity analysis

\begin{tabular}{lccc}
\hline Water source & $\delta^{18} \mathrm{O}$ & $\delta \mathrm{D}$ & ${ }^{222} \mathrm{Rn}$ \\
& $\%$ \%o & $\mathrm{dpm} \mathrm{L}{ }^{-1}$ \\
\hline Surface snow & -11 to -16 & -78 to -118 & 0 \\
Glacial ice & -25 to -30 & -190 to -230 & 0 \\
Delayed-flow waters & -27 to -30 & -206 to -230 & $200-1600$
\end{tabular}

glacier outflow stream isotope values (Table 1) were used to solve the system of equations using singular value decomposition. The radon content in the snow and glacial ice endmembers $\left({ }^{222} \mathrm{Rn}_{1}\right.$ and $\left.{ }^{222} \mathrm{Rn}_{2}\right)$ was set to zero (negligible in situ source of ${ }^{222} \mathrm{Rn}$ ). To initially solve the model, the highest radon activity measured in the ' $N$ ' outflow stream $(210 \mathrm{dpm}$ $\mathrm{L}^{-1}$ ) was operationally defined as ${ }^{222} \mathrm{Rn}_{3}$, effectively normalizing the entire dataset to this maximum concentration. In this study the sediment radon flux to the delayed-flow reservoir is assumed to be a continuous, steady-state process, so a loss term due to radioactive decay is not included in the radon end-member mixing equation.

\subsection{Mixing-model sensitivity analysis}

A sensitivity analysis employing a range of end-member values (Table 2) was conducted to put envelopes of uncertainty on the model fraction results $\left(f_{1}, f_{2}, f_{3}\right)$ by simultaneously varying each of the end-member water reservoir values across a range of reasonably determined limits. The range of surface snow $\delta^{18} \mathrm{O}$ values utilized was chosen to incorporate a maximum isotopic depletion from the original snow during metamorphism and melting (Taylor and others, 2001). Though the mean snowmelt will become progressively enriched throughout the summer melt season due to the early removal of isotopically light water (Cooper, 1998; Taylor and others, 2001), this isotopic enrichment is difficult to predict without additional samples of the total snowpack oxygen isotope signature. However, the model results will be most affected by the potential for depleted snow end-member values, which encroach on the glacial ice $\delta^{18} \mathrm{O}$ values. The glacial ice $\delta^{18} \mathrm{O}$ values were chosen to reflect the range of ice isotopic values across the elevation range of the ' $N$ ' glacier catchment that could potentially contribute to the outflow waters. The range of delayed-flow $\delta{ }^{18} \mathrm{O}$ values employed in the sensitivity analysis encapsulated the $\delta^{18} \mathrm{O}$ content of the groundwater and basal ice at ' $N$ ' glacier. Corresponding $\delta \mathrm{D}$ ranges for each end-member water source were calculated directly from these $\delta^{18} \mathrm{O}$ values using the global meteoric waterline $\left(\delta \mathrm{D}=8 \delta^{18} \mathrm{O}+10\right)$. The range of potential ${ }^{222} \mathrm{Rn}$ activities in the delayed-flow end-member was defined using the maximum activity measured in the ' $N$ ' outflow stream as the lower bound and the lowest groundwater radon activity measured in this study as an upper bound. A better estimate of the ${ }^{222} \mathrm{Rn}$ activity in the delayed-flow waters could be attained by sampling outflow waters during the early season before they are diluted by any surface input. This could be achieved with standard automated continuous radon monitors that measure the ${ }^{222} \mathrm{Rn}$ activity of the outflow stream (e.g. Dulaiova and others, 2005; Schmidt and others, 2008). 


\subsection{Transit time model}

The surface snow and glacial ice fraction results $\left(f_{1}\right.$ and $\left.f_{2}\right)$ from the isotope model were used to estimate a transit time for snowmelt from the surface to its exit at the glacier front using ${ }^{7} \mathrm{Be} .{ }^{7} \mathrm{Be}$ is continuously produced in the atmosphere and is deposited to the surface environment (e.g. the icesheet surface) via wet (precipitation events) and dry (aerosol) deposition (Nimz, 1998). Its unique atmospheric source in combination with its short half-life $\left(\tau_{1 / 2}=53.3\right.$ days $)$ suggests that ${ }^{7}$ Be should be present in the surface snow end-member, while occurring below detection levels in glacial ice and delayed-flow waters that are older than $\sim 300$ days. Thus, assuming constant production on the surface and no ${ }^{7} \mathrm{Be}$ in the delayed-flow reservoir $\left(f_{3}\right)$, the ${ }^{7}$ Be activity in the outflow stream can be described using a steady-state model:

$$
{ }^{7} \mathrm{Be}:\left(f_{1}{ }^{7} \mathrm{Be}_{1, t 0}+f_{2}{ }^{7} \mathrm{Be}_{2}\right)_{t 0} \mathrm{e}^{-\lambda t}={ }^{7} \mathrm{Be}_{4 \mathrm{eff}, t}
$$

where $t$ is time (days), $\lambda$ is the decay constant for ${ }^{7} \mathrm{Be}$ $\left(0.013 \mathrm{~d}^{-1}\right),{ }^{7} \mathrm{Be}_{1, t 0}$ is the ${ }^{7} \mathrm{Be}$ activity of the surface snow end-member water source, ${ }^{7} \mathrm{Be}_{2}$ is the ${ }^{7} \mathrm{Be}$ activity of the glacial ice, and ${ }^{7} \mathrm{Be}_{4 \text { eff, } t}$ is the effective ${ }^{7}$ Be activity in the ${ }^{N} \mathrm{~N}^{\prime}$ glacier outflow stream. ${ }^{7} \mathrm{Be}_{4 \mathrm{eff}, t}$ accounts for any scavenging of ${ }^{7} \mathrm{Be}$ onto subglacial particles and is calculated as the sum of the ${ }^{7} \mathrm{Be}$ in the ${ }^{N} \mathrm{~N}^{\prime}$ glacier outflow stream $\left({ }^{7}\right.$ Be $\left.\mathrm{e}_{\text {dissolved }}\right)$ and the ${ }^{7} \mathrm{Be}$ scavenged by particles in the subglacial environment $\left({ }^{7} \mathrm{Be}_{\text {particulate }}\right)$. The former was measured in the ${ }^{\prime} \mathrm{N}$ ' outflow stream on 21 May, and the latter was estimated using

$$
{ }^{7} \mathrm{Be}_{\text {particulate }}=K_{\mathrm{d}} C_{\mathrm{p}} \cdot{ }^{7} \mathrm{Be}_{\text {dissolved }}
$$

where $K_{\mathrm{d}}$ is particle-water coefficient ( ${ }^{7} \mathrm{Be} / \mathrm{mass}$ of particles $) /\left({ }^{7} \mathrm{Be} / \mathrm{mass}\right.$ of water $\left.)\right)$ and $C_{\mathrm{p}}$ is suspended sediment concentration $\left(\mathrm{mg} \mathrm{mL}^{-1}\right)$ measured in May. A $K_{\mathrm{d}}$ value of 5000 was assumed, which is within the range of previously published ${ }^{7}$ Be $K_{d}$ values $\left(10^{3}-10^{4}\right)$ (Olsen and others, 1986). Rearranging Equation (5) to solve for time yields

$$
t=-1 / \lambda \ln \left(\frac{{ }^{7} \mathrm{Be}_{4 \mathrm{eff}, t}}{f_{1} \cdot{ }^{7} \mathrm{Be}_{1, t 0}+f_{2} \cdot{ }^{7} \mathrm{Be}_{2, t 0}}\right) .
$$

Here time is defined as the transit time from the glacier surface to the front since ${ }^{7} \mathrm{Be}$ is only produced on the surface, and we have accounted for any sinks (scavenging) in the subglacial environment.

\section{RESULTS AND DISCUSSION}

\subsection{Climatology and discharge}

' $N$ ' glacier discharge was highly sensitive to air-temperature fluctuations, with the two clearly co-varying throughout the melt season (Fig. 2a and b). We did not capture the melt onset, as there was already meltwater discharge on our arrival at the field site on 19 May. Nonetheless, a cold period towards the beginning of our record (days 142-144), characterized by subfreezing air temperatures, reduced discharge almost to zero. Following this cold period, air temperature and discharge increased from mid-May to early June as the melt season progressed. Daily-average temperatures at the ice edge then generally remained above $6^{\circ} \mathrm{C}$ for the remainder of the study period. Daily-average discharge also stabilized around $1.6-1.8 \mathrm{~m}^{3} \mathrm{~s}^{-1}$ until late July, when a cold period precipitated a drop in discharge back towards early-season values. We also observed a strong diurnal cycle in subglacial stream discharge that was highly responsive to, although offset from, the insolation-driven diurnal temperature cycle. Peak discharge lagged peak air temperature by an average of 2.4 hours (range $1-5.6$ hours), while the average lag in minimum discharge was 2.7 hours (range 0.35 4.7 hours) from the minimum temperature. The mean diurnal amplitude in the temperature and discharge records was $7.3^{\circ} \mathrm{C}$ and $0.39 \mathrm{~m}^{3} \mathrm{~s}^{-1}$, with maximum and minimum daily discharges occurring between 15:00 and 21:00 and 4:00 and 8:00, respectively.

\subsection{Radon as a tracer for delayed-flow waters}

We did not detect any radon in a sample from a supraglacial meltwater pond on the surface of ' $\mathrm{N}$ ' glacier, thus confirming our assumption that surface snow and glacial ice would be devoid of radon due to negligible sediment inventories on the ice-sheet surface. Conversely, as expected, radon activities in the groundwater samples were very high $\left(1626 \pm 48.8\right.$ and $\left.2750 \pm 63.3 \mathrm{dpm} \mathrm{L} \mathrm{L}^{-1}\right)$. These activities were consistent with the laboratory-derived pore-water radon activities (range $1285 \pm 43.3$ to $3045 \pm 132 \mathrm{dpm} \mathrm{L}^{-1}$ ), thus indicating that the groundwater samples collected in this study represent saturated flow. We observed seasonal differences in the amount of radon detected in the ' $N$ ' glacier outflow stream waters. The mean activity of the May samples was much higher $\left(75.6 \mathrm{dpm} \mathrm{\textrm {L } ^ { - 1 }}\right)$

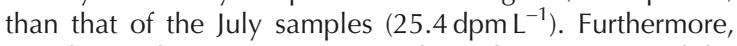
we observed a greater range in the radon activities of the outflow stream in May (16.9-210 dpm $\mathrm{L}^{-1}$ ) compared to July (10.4-35.7 dpm L $\mathrm{L}^{-1}$ ) (Fig. 2c). Thus, during at least some periods in the late spring, the ' $\mathrm{N}$ ' stream outflow waters had high radon activities, whereas at the height of the summer melt season the outflow waters had universally low radon activities. For comparison, the open ocean has an average radon activity of $\sim 0.01 \mathrm{dpm} \mathrm{L} \mathrm{L}^{-1}$ (Broecker and Peng, 1982). In groundwater, radon activities can vary greatly, but, in general, activities range from hundreds to thousands of $\mathrm{dpm} \mathrm{L} \mathrm{L}^{-1}$ (Charette and others, 2008 and references therein). We were not able to resolve a diurnal cycle in the ' $N$ ' outflow radon activity during the 12 July high-resolution time series due to the low activities measured throughout this day (27.3-31.8 dpm $\left.\mathrm{L}^{-1}\right)$. Earlier in the season, however, we found that the maximum daily radon activity on 31 May (75.5 dpm $\mathrm{L}^{-1}$ at 06:45) occurs within the period when daily discharge was at a minimum (although we lack continuous discharge measurements during that time). Moreover, we observed the lowest radon activity $\left(47.5 \mathrm{dpm} \mathrm{L}^{-1}\right)$ at 18:25, when daily discharge was at a maximum. These preliminary data indicate that radon may be useful in resolving the diurnal contribution of delayed-flow waters to total outflow in the early season, but this application requires more frequent sampling. Thus, we limit further discussion of radon to seasonal trends.

Radon in water that is physically decoupled from its sediment or rock source is subject to decay on a timescale determined by its half-life (Kraemer and Genereux, 1998). Thus, subglacial outflow radon activities in line with published groundwater values require substantial steadystate sediment-water interaction. To quantify the potential for suspended sediment to explain the observed radon values, we collected replicate unfiltered samples from the mouth of the ' $\mathrm{N}$ ' outflow; one sample was analyzed immediately, while the other was measured after one radon half-life. The decay-corrected activities of the samples were 

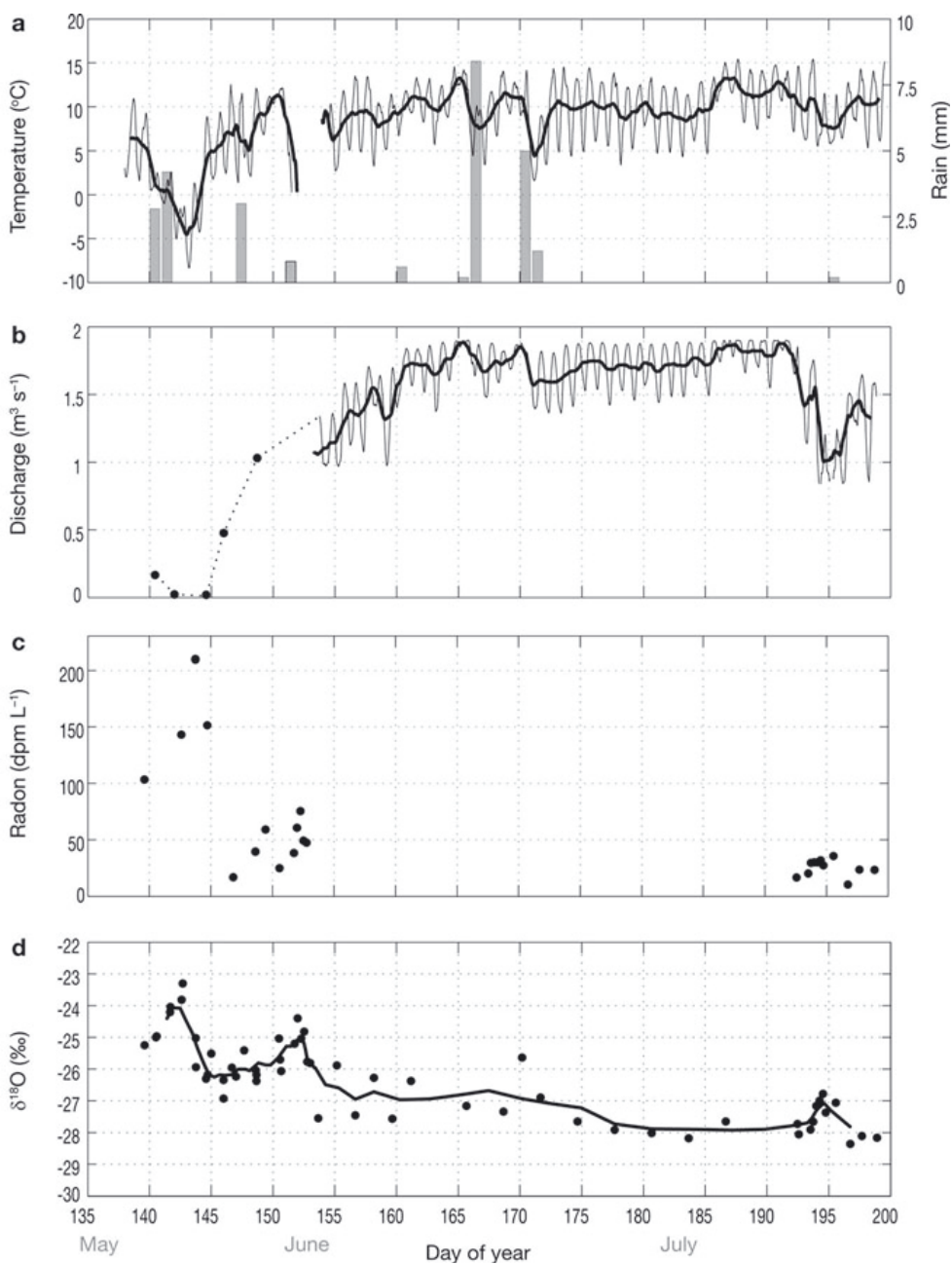

Fig. 2. (a) Plot of 3 hour (thin black line) and daily (thick black line) average air temperatures, with total daily rainfall in the gray bars (b) Three-hour (thin black line) and daily (thick black line) average discharge at ' $\mathrm{N}^{\prime}$ glacier. (c) Radon activities. (d) $\delta^{18} \mathrm{O}$ content (black dots) and five-point moving average (black line) in the ' $\mathrm{N}$ ' glacier outflow stream. The discharge record is confined to point measurements from 19 to 31 May. Discontinuous lines in the temperature and discharge records reflect gaps in the data.

the same, indicating that ${ }^{226} \mathrm{Ra}$ in the stored sample sediment was not a significant source of radon. We therefore conclude that the presence of radon in bulk outflow waters necessitates some delayed-flow component that has had substantial interaction with the bed. As further evidence of this idea, the regression (model II, geometric mean) of radon and EC was significant $\left(r^{2}=0.87\right.$, $p<0.01$ ) (Fig. 3). However, unlike EC, radon is not subject to the dissolution chemistries of a wide range of solutes and thus can potentially be utilized for quantitative hydrograph separation.

\subsection{Radon evasion in subglacial channels}

Although radon is water-soluble, the radon will partition into the air phase in an air-water system (Kraemer and Genereux, 1998). Loss due to evasion is a function of temperature and the amount of radon present in the air, so evasion could be problematic late in the melt season when subglacial channels may not be entirely water-full. Moreover, water flow in the subglacial channels is often faster

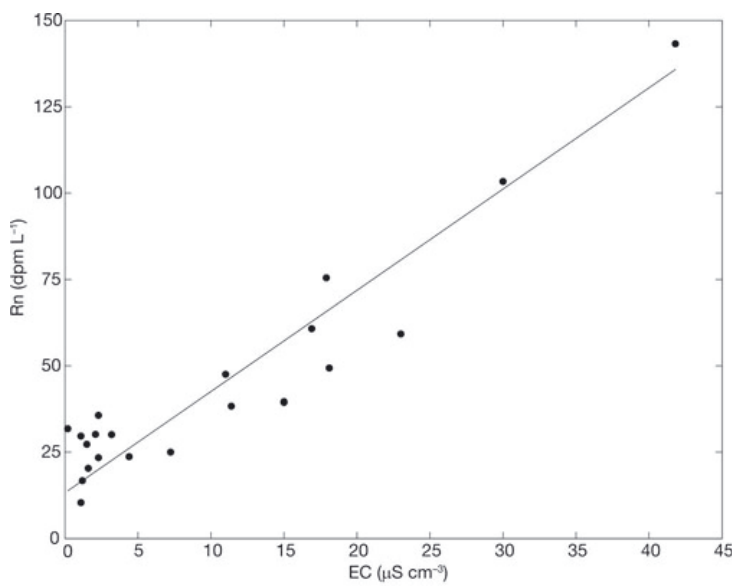

Fig. 3. Model II regression (geometric mean) of EC and radon activity in the ' $\mathrm{N}$ ' glacier outflow stream waters. 
Table 3. ${ }^{222} \mathrm{Rn}$ activities in the ' $\mathrm{N}$ ' glacier outflow stream on falling and rising discharge limbs from 10 to 16 July 2008

\begin{tabular}{lccc}
\hline Julian day & Discharge observations & $\begin{array}{c}\text { Mean daily discharge } \\
\mathrm{m}^{3} \mathrm{~s}^{-1}\end{array}$ & $\begin{array}{c}{ }^{222} \mathrm{Rn} \\
\mathrm{dpm} \mathrm{L} \mathrm{L}^{-1}\end{array}$ \\
\hline 192 & Start of falling limb & 1.7 & 16.7 \\
193 & Falling limb & 1.5 & 20.3 \\
194 & Falling limb & 1.2 & 31.8 \\
195 & Bottom of falling limb & 1.0 & 35.7 \\
196 & Rising limb & 1.2 & 10.4 \\
197 & Top of rising limb & 1.4 & 23.7 \\
198 & Falling limb & 1.3 & 23.4 \\
\end{tabular}

and more turbulent at the peak of the summer melt season, which may enhance gas exchange loss (Kraemer and Genereux, 1998). Thus, if evasion were the dominant process influencing radon in the ' $\mathrm{N}$ ' glacier outflow stream we would expect to find lower radon activities toward the end of a falling discharge limb. Instead we observed increases in radon during times when discharge was decreasing and subglacial channels were less full (e.g. days 192-195), and the largest radon activities occurred at the discharge minimum (Table 3). Thus, dilution of the delayed-flow waters with radon-free surface input appears to have had the greatest effect on radon values in the ' $\mathrm{N}$ ' outflow stream.

6.4. Water isotopes as a tracer in a GrIS outlet glacier We found distinct $\delta^{18} \mathrm{O}$ values for the surface-snow $(-11$ to $-13 \%$ ) and glacial-ice ( -26 to $-30 \%$ ) end-members measured across our study region (Table 4). This difference means that the snow and glacial ice reservoir $\delta^{18} \mathrm{O}$ values do not overlap and thus are useful as passive flow tracers. Conversely, our 'basal-ice' (ice collected at $100 \mathrm{~m}$ elevation at the glacier margin) sample values (-29.6\%) were not sufficiently isotopically distinct from glacial ice values estimated across the surface of the catchment $(-25.5$ to $-28.2 \%$ ) to separate the delayed-flow water source from the glacier ice reservoir. Thus it was necessary to delineate these reservoirs from each other with the radon end-member mixing equation. An additional groundwater sample near the front of ' $\mathrm{N}$ ' glacier also possessed a depleted $\delta^{18} \mathrm{O}$ signature $(-27.8 \%$ ), suggesting that groundwater in this region is derived primarily from glacial ice melt. Although we limit our discussion to the $\delta^{18} \mathrm{O}$ values, the trends observed in the oxygen isotope values are also applicable to the deuterium data, since $\delta^{18} \mathrm{O}$ and $\delta \mathrm{D}$ covary on a global scale (Craig, 1961).

\subsection{Isotope-mixing model}

The end-member mixing equations used in this study assume a simplified drainage system limited to three conceptual end-member water sources: (1) surface snow, (2) glacial ice and (3) delayed-flow waters. This was necessary to determine the applicability of radon as a hydrological tracer in a glacial setting, and to produce an initial chemical mixing model, although we recognize that we have oversimplified the subglacial drainage system by categorizing glacial flow components into three broad water source reservoirs (Sharp and others, 1995).

Model results showed that the snowmelt and delayedflow waters comprised a greater fraction of the total outflow
Table 4. Measured and estimated $\left({ }^{*}\right) \delta^{18} \mathrm{O}$ ratios of surface-snow, glacial-ice and groundwater samples

\begin{tabular}{lcccc}
\hline Water source & \multicolumn{4}{c}{$\delta^{18} \mathrm{O}$} \\
& $100 \mathrm{~m}$ elev. & $300 \mathrm{~m}$ elev. & $500 \mathrm{~m}$ elev. & $1000 \mathrm{~m}$ elev. \\
\hline Surface snow & $-11 \% 0^{*}$ & $\begin{array}{c}-12.3 \% 0 \\
(n=1)\end{array}$ & $-13 \%^{*}$ & \\
Glacial ice & $\begin{array}{c}-29.6 \% 0 \\
(n=2)\end{array}$ & $\begin{array}{c}-28.2 \% 0 \\
(n=3)\end{array}$ & $-25.5 \% 0^{*}$ & $-23.9 \%$ \\
Groundwater & $\begin{array}{c}-27.8 \% \\
(n=1)\end{array}$ & & \\
& & & \\
\end{tabular}

in May (Fig. 4a) than in July (Fig. 4b). In May, delayed flow dominated the discharge (mean $41 \%$ ), followed by nearly equal contributions from surface snowmelt (mean 23\%) and glacial ice melt (mean 26\%). In July, however, the mean fractional contributions from the surface snowmelt and delayed-flow reservoirs decreased to $6 \%$ and $12 \%$, respectively, while the mean glacial ice contribution rose to $82 \%$. This finding was likely due to the removal of seasonal snow from the glacier surface by this time, and dilution of delayed-flow reservoirs with increased glacial ice melt. Scaling the model results with the measured discharge allowed us to compare the discharge contribution of surface snow, glacial ice and delayed flow to the total ' $N$ ' stream discharge from 18 May to 1 June (Fig. 4c) and 11 to 17 July (Fig. 4d). The average snow component $(n=11)$ of total discharge decreased by more than half from May (mean $0.17 \pm 0.04 \mathrm{~m}^{3} \mathrm{~s}^{-1} ; 1$ standard error) to July (mean $0.07 \pm 0.01 \mathrm{~m}^{3} \mathrm{~s}^{-1}$ ), whereas the average glacial ice component $(n=11)$ more than doubled from May (mean $0.43 \pm 0.10 \mathrm{~m}^{3} \mathrm{~s}^{-1}$ ) to July (mean $1.1 \pm 0.09 \mathrm{~m}^{3} \mathrm{~s}^{-1}$ ). By comparison, the average delayed-flow component $(n=11)$ remained a relatively constant contribution between May $\left(0.19 \pm 0.05 \mathrm{~m}^{3} \mathrm{~s}^{-1}\right)$ and July $\left(0.16 \pm 0.01 \mathrm{~m}^{3} \mathrm{~s}^{-1}\right)$.

The results of our isotope-mixing model were a direct consequence of the shifts we observed in the ${ }^{222} \mathrm{Rn}$ activities and $\delta{ }^{18} \mathrm{O}$ and $\delta \mathrm{D}$ ratios of the ' $\mathrm{N}$ ' outflow stream composition from May to July. The highest radon activities were found during times of lowest discharge (Fig. 5a). During the 3 day subfreezing period in May when discharge dropped to near zero, radon activities in the ' $\mathrm{N}$ ' outflow stream peaked at $>100 \mathrm{dpm} \mathrm{L} \mathrm{L}^{-1}$ (Fig. 5a). In July, even though the radon activities were overall much lower than in May, elevated radon (35.7 dpm L $\mathrm{L}^{-1}$ ) coincides with a prominent drop in discharge on day 195 (Fig. 5b). This behavior can best be explained by varying levels of dilution of the delayed-flow waters with a supraglacial water source devoid of radon. This reasoning is consistent with a seasonal evolution of the subglacial drainage structure from a distributed system characterized by chemically enriched outflow waters to a channelized system that facilitates rapid transit of dilute glacial ice melt.

The difference between the stable-isotope signatures of the snow and ice reservoirs at ' $N$ ' glacier is sufficiently large that a change in $\delta^{18} \mathrm{O}$ runoff composition can likely be attributed to a water source change. In late spring when dischargeis low, and snowmelt feeds a predominantly distributed subglacial drainage system, we measured enriched $\delta^{18} \mathrm{O}$ values in the ' $\mathrm{N}$ ' outflow stream, compared to 

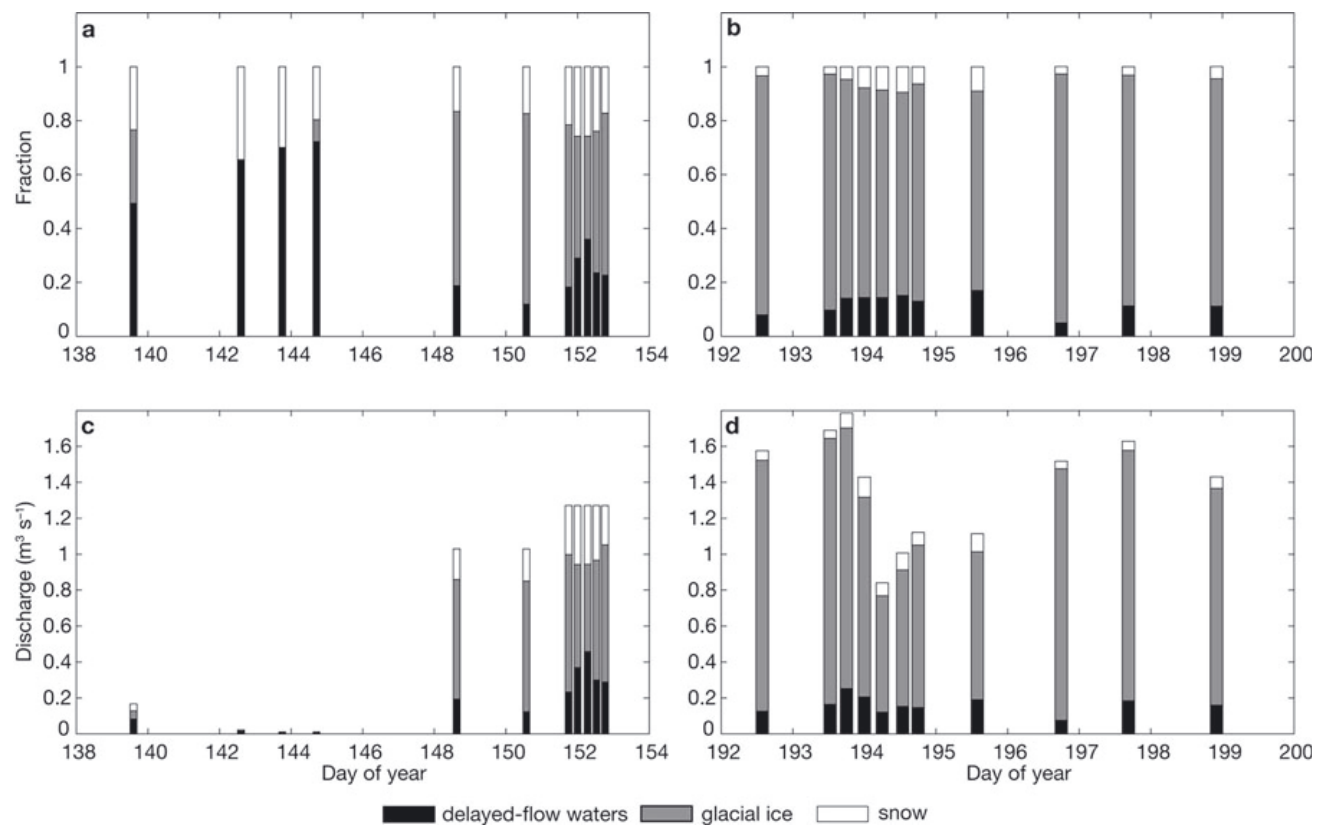

Fig. 4. Stacked bar plots of isotope-mixing model solutions for the fractions of surface snow, glacial ice and delayed-flow waters comprising the ' $\mathrm{N}$ ' glacier outflow stream waters from (a) 18 May to 1 June and (b) 11 to 17 July, and scaled contributions from each reservoir in (c) May and (d) July.

later in the season (Fig. 2d). Indeed, the most enriched values occurred over the 3 day span that discharge dropped to near zero. Subsequently there is a decrease in the stableisotope signature of the ' $\mathrm{N}$ ' glacier discharge as the melt season progresses from late spring to the summer. This trend is consistent with a seasonal shift in water source reservoirs from a snow and ice contribution in late spring to a purely glacial ice contribution at the height of the summer melt season.

In addition to the overall seasonal decline, our $\delta^{18} \mathrm{O}$ record exhibited higher-frequency variability, suggesting that changes in meltwater source contributions and/or drainage system evolution may also have occurred during synoptic-scale events. Although we lacked the temporal resolution required to explore this variability in full, one such event late in the melt season is reasonably well resolved. On day 195 there was a notable spike in the ' $N$ ' glacier subglacial stream $\delta^{18} \mathrm{O}$ values above the late-season mean coincident with a prominent drop in air temperature and discharge, and an increase in radon activity (Fig. 2). One possible explanation for this event is cooling air temperatures across the glacier surface leading to a decrease in $\delta^{18} \mathrm{O}$-depleted glacier ice melt. This decrease in total surface meltwater input to the subglacial resulted in a relatively higher base flow contribution (characterized by residual stored $\delta^{18} \mathrm{O}$-enriched snowmelt) to the bulk runoff during this event. Another possible explanation for this isotopic excursion is a rainfall event $(0.2 \mathrm{~mm})$ recorded that day (Fig. 2a) which would also yield an enriched $\delta^{18} \mathrm{O}$ signature. Larger rainfall events in our record (e.g. $8.4 \mathrm{~mm}$ on day 166), however, did not correspond to enriched $\delta^{18} \mathrm{O}$ runoff values. Furthermore, rainfall events should increase stream discharge, whereas we observed a decrease in stream discharge during this event.

\subsection{Mixing-model sensitivity analysis}

The sensitivity analysis revealed that for the entire dataset (May and July) the contribution from the surface snow reservoir to the total outflow varied from a mean maximum of $26 \%$ to a mean minimum of $0.9 \%$. Similarly, the delayedflow fraction varied from a mean maximum of $26 \%$ to a slightly higher mean minimum of $3.4 \%$. Not surprisingly, the glacial ice fraction exhibited the highest mean maximum and minimum values, varying from $97 \%$ to $49 \%$. Results of the sensitivity analysis are also displayed as the maximum and minimum flow contributions $\left(\mathrm{m}^{3} \mathrm{~s}^{-1}\right)$ from the surface snow, glacial ice and delayed-flow reservoirs from May (Fig. 6a) and July (Fig. 6b). In order to identify meaningful estimates, we constrained the sensitivity analysis so that no flow contribution was permitted to fluctuate below zero. When discharge was very low, we were not able to differentiate the flow contribution $\left(\mathrm{m}^{3} \mathrm{~s}^{-1}\right)$ from the different component reservoirs accurately (Fig. 6a). Additionally, though we were able to drive the snow contribution to zero, there was always a delayed-flow component that is diluted by an increasing ice component throughout the season. This analysis illustrates that we are currently able to determine the flow contribution from each of the defined water source reservoirs within an absolute maximum and minimum value. Further improvements to the flow estimates would benefit most from better characterization of the delayed-flow radon end-member.

\section{TRANSIT TIME ESTIMATES}

We observed detectable ${ }^{7}$ Be activity $\left(7.7 \mathrm{dpm} \mathrm{L}^{-1}\right)$ in the ' $\mathrm{N}$ ' supraglacial pond in May, which we use as an analogue for the potential ${ }^{7} \mathrm{Be}$ activity of surface snow in this study. This 

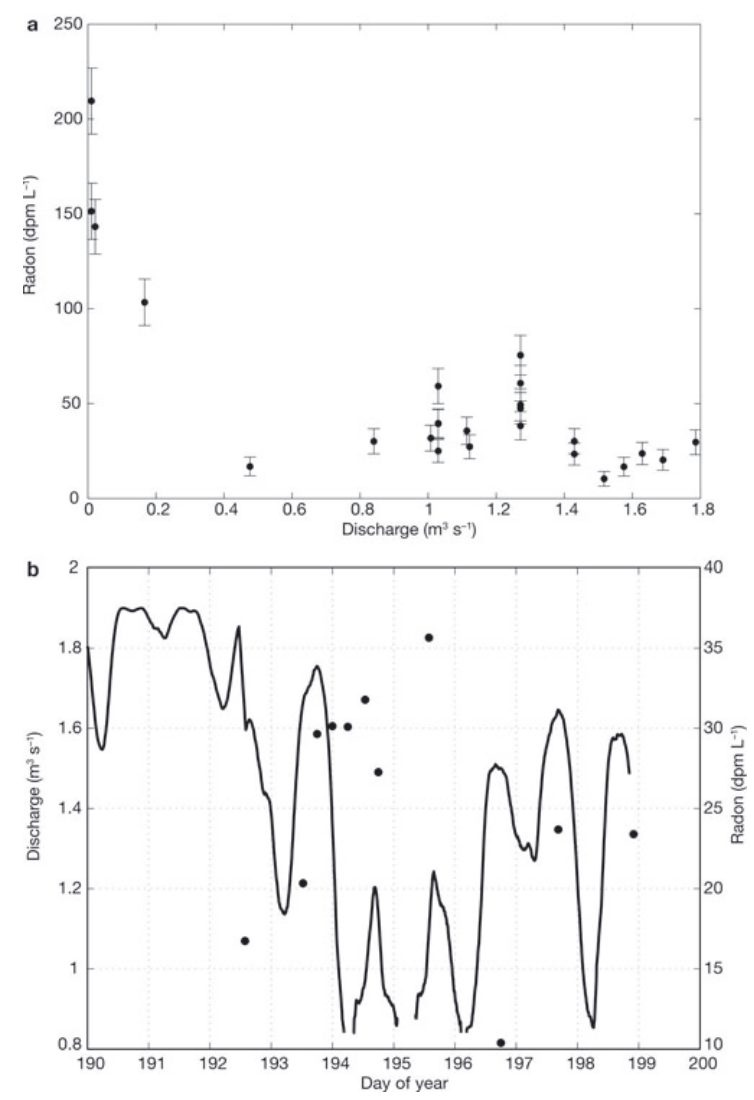

Fig. 5. (a) Radon activities ( \pm one standard error) in the ' $N$ ' glacier outflow stream plotted against daily average discharge, and (b) 3 hour average discharge and measured radon activities in the ' $\mathrm{N}$ ' glacier outflow stream from 11 to 17 July. Discontinuous lines in the discharge record reflect gaps in the data. activity is within the range of previously reported ${ }^{7} \mathrm{Be}$ activities in fresh snow at Summit, Greenland (2.67$76.5 \mathrm{dpm} \mathrm{L} \mathrm{L}^{-1}$ ), but below the reported median $(15.3 \mathrm{dpm}$ $\mathrm{L}^{-1}$ ) (Dibb, 1990). The wide variability in reported freshsnow ${ }^{7} \mathrm{Be}$ activities likely reflects atmospheric inventory depletion and wet deposition-related dilution effects of precipitation-event frequency and duration (Nimz, 1998). For example, high ${ }^{7} \mathrm{Be}$ activities may result from a short snowfall event following a period of minimal precipitation. Conversely, lower snow activities may be explained by a relatively large snowfall event following a series of recent precipitation events. Our sample may have had lower ${ }^{7} \mathrm{Be}$ activity compared to the fresh snow collected at Summit because it represents a composite of fresh and older snow on the surface of ' $\mathrm{N}$ ' glacier. Comparatively, meltwater derived from recent glacial ice melt measured at the inland site in July had an extremely low ${ }^{7}$ Be activity $\left(0.04 \mathrm{dpm} \mathrm{L}^{-1}\right)$, an indication that its original ${ }^{7} \mathrm{Be}$ inventory had been lost via decay. Thus, ${ }^{7} \mathrm{Be}$ in outflow water can only be derived from a young supraglacial source that has originated at the surface $<1$ year before. On 21 May the ${ }^{7}$ Be activity of the ${ }^{\prime} \mathrm{N}^{\prime}$ glacier outflow stream was $1.05 \mathrm{dpm} \mathrm{L}^{-1}$, and on 11 July the ${ }^{7} \mathrm{Be}$ activity was $0.03 \mathrm{dpm} \mathrm{L}^{-1}$. The low July ${ }^{7} \mathrm{Be}$ signal was similar to the recent glacial ice-melt ${ }^{7} \mathrm{Be}$ signal, and most likely represented a switch in end-member contribution from snowmelt to ice melt. The May value, however, was consistent with a hydrological connection between surface melt and subsurface discharge at this point in the season. However, we cannot rule out the possibility that the May ${ }^{7}$ Be signal in the ' $\mathrm{N}$ ' glacier outflow stream resulted from the release of supraglacial waters that had been stored at the bed for $<300$ days or in basal crevasses (Harper and others, 2010).

We used the fractions from the isotope-mixing model for the surface snow and glacial ice contributions on 21 May to solve for a transit time (Equation (7)). Since ${ }^{7} \mathrm{Be}$ is particlereactive (Hawley and others, 1986; Olsen and others, 1986)
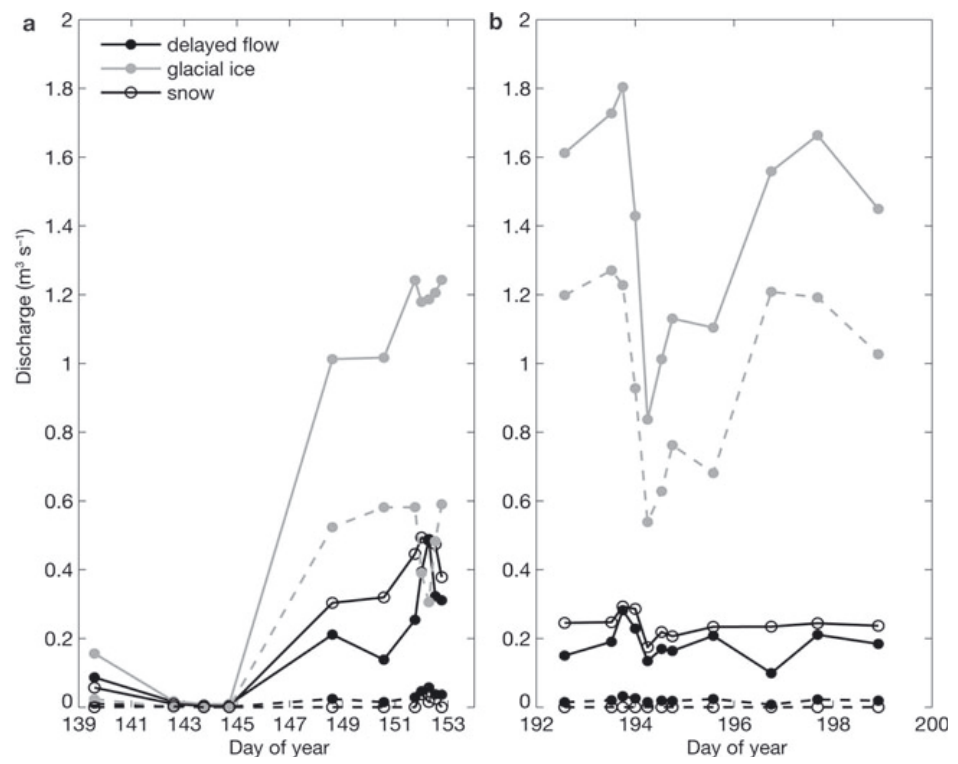

Fig. 6. Sensitivity analysis illustrating maximum (solid lines) and minimum (dashed lines) flow contributions from the surface snow, glacial ice and delayed-flow water sources from (a) 18 May to 1 June and (b) 11 to 17 July. 
and thus could have adsorbed to solids during travel through the subglacial environment, we also included a correction that describes scavenging of ${ }^{7} \mathrm{Be}$ onto particles in the subglacial environment (Equation (6)). Given these assumptions, we estimated that supraglacial waters took $\sim 7.5$ days to travel from the surface to the glacier mouth. For comparison, distributed drainage-system transit times (estimated using velocities from dye-tracing experiments in Nienow and others, 1998) at Haut Glacier d'Arolla, Switzerland, which has a similar catchment size to ' $\mathrm{N}$ ' glacier, range from $\sim 6$ to $<1$ day(s) for a $5 \mathrm{~km}$ flow path. However, we should note that our calculated time estimate depends on the accuracy of our assumed partition coefficient, $K_{\mathrm{d}}$, and the surface ${ }^{7}$ Be activity. Nonetheless, ${ }^{7}$ Be may hold promise as a tracer for snowmelt in early-season distributed drainage systems with similar or longer transit times.

\section{SYNTHESIS}

Results from our multi-component isotope-mixing model provide broad separation of water reservoir contributions, thus providing a potential new direction in the application of chemical mixing models to study glacier hydrology. Based on the results from this study, we furthermore suggest that these methods could be successfully scaled up to investigate the subglacial hydrology of the much larger outlet glaciers that drain the bulk of the GrIS. Some practical and technological challenges remain to be solved in regularly sampling discharge and radon at large land-terminating glaciers (e.g. in flood plains, large channels or braided river environments) and in large marine-terminating glaciers (tidewater environments). This effort would also require comprehensive sampling of the glacial ice end-member water isotope values across each of these larger catchments.

Focusing our study on a small land-terminating glacier on the southwestern margin of the GrIS, we show that there is a relatively constant and chemically enriched delayed (basal) flow component present throughout the melt season. These delayed-flow waters comprise a greater fraction of the total discharge in May compared to July, and are diluted first by snowmelt and then by increasing amounts of rapidly flowing ice melt as the season progresses. In alpine glaciers, chemically enriched delayed-flow waters (e.g. snowmelt, basal melt, groundwater) are characteristic of distributed drainage systems, which transmit meltwater slowly through the glacier via a hydraulically inefficient network. As the snowline retreats and surface meltwater input to the bed increases, the subglacial drainage system structure evolves to a channelized drainage system, which can more efficiently export the surface glacial ice melt. Though such seasonal subglacial drainage evolution is well documented in alpine systems (Hubbard and Nienow, 1997; Nienow and others, 1998; Cuffey and Paterson, 2010), its existence under land-terminating sectors of the GrIS has only recently been hypothesized (Shepherd and others, 2009; Bartholomew and others, 2010) and has not been directly observed. The findings from this study offer a hydrochemical line of evidence for this hypothesis, albeit at a comparatively much smaller outlet glacier, and bolster the need to incorporate these dynamically significant subglacial processes into GrIS modeling efforts.

From a biogeochemical perspective, knowledge of the seasonal controls on end-member water-source contributors to bulk discharge provides greater understanding of the potential for high temporal variability of carbon, nutrient and metal export from subglacial environments to downstream marine ecosystems. Previous studies have suggested that water draining a distributed drainage system contains much greater concentrations of these biogeochemically important species, compared to the waters draining a channelized system (Tranter and others, 2005). Thus, total annual flux calculations of carbon, nutrient and metal export require knowledge of the base flow $\left(\mathrm{m}^{3} \mathrm{a}^{-1}\right)$ exiting a glacier. Our isotope-mixing model shows promise at being able to provide reasonable quantitative estimates of snow, ice and delayed-flow components comprising bulk meltwater discharge from a land-terminating GrIS glacier. These flow estimates can be used as a first-order approximation of base flow emanating from similar catchments around the GrlS throughout the year.

\section{ACKNOWLEDGEMENTS}

This research was supported by the WHOI Clark Arctic Research Initiative (E.B.K., S.B.D., M.A.C.), the WHOI Ocean Ventures Fund (M.P.B.), the US National Science Foundation ARC-05200077 (S.B.D.), NASA (S.B.D.), the Natural Sciences and Engineering Research Council of Canada (M.P.B.) and the WHOI Climate Change Institute (M.P.B.). We acknowledge I. Joughin for kindly providing InSAR velocity data. We are very grateful to $M$. Behn and D. Glover for assistance with data analysis, to M. Sharp and $\mathrm{K}$. Longnecker for comments and advice that improved the manuscript, and to B. Gready, M. Behn, I. Joughin, M. Evans, A. Criscitello and R. Harris for assistance in the field.

\section{REFERENCES}

Andrews, J.E., C. Hartin and K.O. Buesseler. 2008. ${ }^{7}$ Be analyses in seawater by low background gamma-spectroscopy. J. Radioanal. Nucl. Chem., 277(1), 253-259.

Bartholomew, I., P. Nienow, D. Mair, A. Hubbard, M.A. King and A. Sole. 2010. Seasonal evolution of subglacial drainage and acceleration in a Greenland outlet glacier. Nature Geosci., 3(6), $408-411$.

Benn, D.I. and D.J.A. Evans. 1998. Glaciers and glaciation. London, Arnold.

Bhatia, M.P. S.B. Das, K. Longnecker, M.A. Charette and E.B. Kujawinski. 2010. Molecular characterization of dissolved organic matter associated with the Greenland ice sheet. Geochim. Cosmochim. Acta, 74(13), 3768-3784.

Box, J.E. and K. Ski. 2007. Remote sounding of Greenland supraglacial melt lakes: implications for subglacial hydraulics. J. Glaciol., 53(181), 257-265.

Box, J.E. and 8 others. 2006. Greenland ice sheet surface mass balance variability (1988-2004) from calibrated Polar MM5 output. J. Climate, 19(12), 2783-2800.

Broecker, W.S. and T.H. Peng. 1982. Tracers in the sea. New York, Eldigio Press.

Brown, G.H. 2002. Glacier meltwater hydrochemistry. Appl. Geochem., 17(7), 855-883.

Brown, G.H., M.J. Sharp, M. Tranter, A.M. Gurnell and P.W. Nienow. 1994. Impact of post-mixing chemical reactions on the major ion chemistry of bulk meltwaters draining the Haut Glacier d'Arolla, Valais, Switzerland. Hydrol. Process., 8(5), 465-480.

Burnett, W.C. and H. Dulaiova. 2003. Estimating the dynamics of groundwater input into the coastal zone via continuous radon222 measurements. J. Environ. Radioactiv., 69(1-2), 21-35. 
Cable, J.E., W.C. Burnett, J.P. Chanton and G.L. Weatherly. 1996. Estimating groundwater discharge into the northeastern Gulf of Mexico using radon-222. Earth Planet. Sci. Lett., 144(3-4), 591-604.

Charette, M.A., W.S. Moore and W.C. Burnett. 2008. Uraniumand thorium-series nuclides as tracers of submarine groundwater discharge. In Krishnaswami, S. and J. Kirk Cochran, eds. $U$-Th series nuclides in aquatic systems. Amsterdam, Elsevier, 155-191. (Radioactivity in the Environment 13.)

Clark, I.D. and P. Fritz. 1997. Environmental isotopes in hydrogeology. Boca Raton, FL, CRC Lewis.

Collins, D.N. 1979. Quantitative determination of the subglacial hydrology of two Alpine glaciers. J. Glaciol., 23(89), 347-362.

Cooper, L.W. 1998. Isotopic fractionation in snow cover. In Kendall, C. and J.J. McDonnell, eds. Isotope tracers in catchment hydrology. New York, Elsevier, 119-136.

Corbett, D.R., W.C. Burnett, P.H. Cable and S.B. Clark. 1997. Radon tracing of groundwater input into Par Pond, Savannah River Site. J. Hydrol., 203(1-4), 209-227.

Craig, H. 1961. Isotopic variations in meteoric waters. Science, 133(3465), 1702-1703.

Cuffey, K.M. and W.S.B. Paterson. 2010. The physics of glaciers. Fourth edition. Oxford, Butterworth-Heinemann.

Dansgaard, W., S.J. Johnsen, H.B. Clausen and N. Gundestrup. 1973. Stable isotope glaciology. Medd. Grønl., 197(2), 1-53.

Das, S.B. and 6 others. 2008. Fracture propagation to the base of the Greenland Ice Sheet during supraglacial lake drainage. Science, 320(5877), 778-781.

Dibb, J.E. 1990. Beryllium-7 and lead-210 in the atmosphere and surface snow over the Greenland ice sheet in the summer of 1989. J. Geophys. Res., 95(D13), 22,407-22,415

Dingman, S.L. 2002. Physical hydrology. Second edition. Long Grove, IL, Waveland Press.

Dulaiova, H., R. Peterson, W.C. Burnett and D. Lane-Smith. 2005. A multi-detector continuous monitor for assessment of ${ }^{222} \mathrm{Rn}$ in the coastal ocean. J. Radioanal. Nucl. Chem., 263(2), 361-363.

Dulaiova, H., M.E. Gonneea, P.B. Henderson and M.A. Charette. 2008. Geochemical and physical sources of radon variation in a subterranean estuary - implications for groundwater radon activities in submarine groundwater discharge studies. Mar. Chem., 110(1-2), 120-127.

Gurnell, A.M. and C.R. Fenn. 1984. Flow separation, sediment source areas and suspended sediment transport in a pro-glacial stream. Catena, Suppl. 5, 109-119.

Harper, J.T., J.H. Bradford, N.F. Humphrey and T.W. Meierbachtol. 2010. Vertical extension of the subglacial drainage system into basal crevasses. Nature, 467(7315), 579-582.

Hawley, N., J.A. Robbins and B.J. Eadie. 1986. The partitioning of ${ }^{7}$ beryllium in fresh water. Geochim. Cosmochim. Acta, 50(6), 1127-1131.

Hood, E. and D. Scott. 2008. Riverine organic matter and nutrients in southeast Alaska affected by glacial coverage. Nature Geosci., 1(9), 583-587.

Hood, E. and 6 others. 2009. Glaciers as a source of ancient and labile organic matter to the marine environment. Nature, 462(7276), 1044-1047.

Hubbard, B. and P. Nienow. 1997. Alpine subglacial hydrology. Quat. Sci. Rev., 16(9), 939-955.

Joughin, I., S.B. Das, M.A. King, B.E. Smith, I.M. Howat and T. Moon. 2008. Seasonal speedup along the western flank of the Greenland Ice Sheet. Science, 320(5877), 781-783.

Jouzel, J. and 12 others. 1997. Validity of the temperature reconstruction from water isotopes in ice cores. J. Geophys. Res., 102(C12), 26,471-26,487.

Kies, A., O. Hengesch, Z. Tosheva, J. Jania and A. Nawrot. 2010. Natural radioactive isotopes in glacier studies. In Barnet, I. and P. Pacherová, eds. Proceedings of the 10th International Workshop on the Geological Aspects of Radon Risk Mapping, 22-25 September 2010, Prague, Czech Republic. Prague, Czech Geological Survey, 162-172.
Kraemer, T.F. and D.P. Genereux. 1998. Applications of uraniumand thorium-series radionuclides in catchment hydrology studies. In Kendall, C. and J.J. McDonnell, eds. Isotope tracers in catchment hydrology. New York, Elsevier, 679-722.

Krawczynski, M.J., M.D. Behn, S.B. Das and I. Joughin. 2009. Constraints on the lake volume required for hydro-fracture through ice sheets. Geophys. Res. Lett., 36(10), L10501. (10.1029/2008GL036765.)

McMillan, M., P. Nienow, A. Shepherd, T. Benham and A. Sole. 2007. Seasonal evolution of supra-glacial lakes on the Greenland Ice Sheet. Earth Planet. Sci. Lett., 262(3-4), 484-492.

Mernild, S.H., G.E. Liston, C.A. Hiemstra, K. Steffen, E. Hanna and J.H. Christensen. 2009. Greenland ice sheet surface massbalance modelling and freshwater flux for 2007, and in a 19952007 perspective. Hydrol. Process., 23(17), 2470-2484.

Mitchell, A., G.H. Brown and R. Fuge. 2001. Minor and trace element export from glacierized Alpine headwater catchment (Haut Glacier d'Arolla, Switzerland). Hydrol. Process., 15(18), 3499-3524.

Nienow, P., M. Sharp and I. Willis. 1998. Seasonal changes in the morphology of the subglacial drainage system, Haut Glacier d'Arolla, Switzerland. Earth Surf. Process. Landf., 23(9), 825-843.

Nimz, G.J. 1998. Lithogenic and cosmogenic tracers in catchment hydrology. In Kendall, C. and J.J. McDonnell, eds. Isotope tracers in catchment hydrology. New York, Elsevier, 247-289.

Olsen, C.R., I.L. Larsen, P.D. Lowry, N.H. Cutshall and M.M. Nichols. 1986. Geochemistry and deposition of ${ }^{7} \mathrm{Be}$ in river-estuarine and coastal waters. J. Geophys. Res., 91(C1), 896-908.

Paterson, W.S.B. 1994. The physics of glaciers. Third edition. Oxford, etc., Elsevier.

Raiswell, R. and 6 others. 2006. Contributions from glacially derived sediment to the global iron (oxyhydr)oxide cycle: implications for iron delivery to the oceans. Geochim. Cosmochim. Acta, 70(11), 2765-2780.

Reeh, N. and H.H. Thomsen. 1993. Using stable isotopes as natural tracers to delineate hydrological drainage basins on the Greenland ice-sheet margin. Chemical Geol., 109(1-4), 281-291.

Richards, K.S. and 9 others. 1996. An integrated approach to modelling hydrology and water quality in glacierized catchments. Hydrol. Process., 10(4), 479-508.

Richter-Menge, J., ed. 2009. The Arctic. Bull. Am. Meteorol. Soc., 90, Special issue, S1-S196.

Ricker, W.E. 1973. Linear regressions in fishery research. J. Fish. Res. Board Can., 30(3), 409-434.

Schmidt, A., M. Schlueter, M. Melles and M. Schubert. 2008. Continuous and discrete on-site detection of radon-222 in ground- and surface waters by means of an extraction module. Appl. Radiat. Isotop., 66(12), 1939-1944.

Sharp, M., G.H. Brown, M. Tranter, I.C. Willis and B. Hubbard. 1995. Comments on the use of chemically based mixing models in glacier hydrology. J. Glaciol., 41(138), 241-246.

Sharp, M., J. Parkes, B. Cragg, I.J. Fairchild, H. Lamb and M. Tranter. 1999. Widespread bacterial populations at glacier beds and their relationship to rock weathering and carbon cycling. Geology, 27(2), 107-110.

Shepherd, A., A. Hubbard, P. Nienow, M. McMillan and I. Joughin 2009. Greenland ice sheet motion coupled with daily melting in late summer. Geophys. Res. Lett., 36(1), L01501. (10.1029/ 2008GL035758.)

Skidmore, M.L., J.M. Foght and M.J. Sharp. 2000. Microbial life beneath a High Arctic glacier. Appl. Environ. Microbiol., 66(8), 3214-3220.

Sokal, R.R. and F.J. Rohlf. 1995. Biometry: the principles and practice of statistics in biological research. Third edition. New York, W.H. Freeman.

Solomon, S. and 7 others, eds. 2007. Climate change 2007: the physical science basis. Contribution of Working Group I to the 
Fourth Assessment Report of the Intergovernmental Panel on Climate Change. Cambridge, etc., Cambridge University Press.

Taylor, S., X. Feng, J.W. Kirchner, R. Osterhuber, B. Klaue and C.C. Renshaw. 2001. Isotopic evolution of a seasonal snowpack and its melt. Water Resour. Res., 37(3), 759-769.

Theakstone, W.H. 2003. Oxygen isotopes in glacier-river water, Austre Okstindbreen, Okstindan, Norway. J. Glaciol., 49(165), 282-298.

Tranter, M. and R. Raiswell. 1991. The composition of the englacial and subglacial component in bulk meltwaters draining the Gornergletscher, Switzerland. J. Glaciol., 37(125), 59-66.

Tranter, M. and 9 others. 1997. Variability in the chemical composition of in situ subglacial meltwaters. Hydrol. Process., 11(1), 59-78.
Tranter, M., M.J. Sharp, H.R. Lamb, G.H. Brown, B.P. Hubbard and I.C. Willis. 2002. Geochemical weathering at the bed of Haut Glacier d'Arolla, Switzerland - a new model. Hydrol. Process., 16(5), 959-993.

Tranter, M., M. Skidmore and J. Wadham. 2005. Hydrological controls on microbial communities in subglacial environments. Hydrol. Process., 19(4), 995-998.

Tsai, V.C. and J.R. Rice. 2010. A model for turbulent hydraulic fracture and application to crack propagation at glacier beds. J. Geophys. Res., 115(F3), F03007. (10.1029/2009JF001474.)

Wadham, J.L., M. Tranter, S. Tulaczyk and M. Sharp. 2008. Subglacial methanogenesis: a potential climatic amplifier? Global Biogeochem. Cycles, 22(2), GB2021. (10.1029/ 2007GB002951.)

MS received 30 November 2010 and accepted in revised form 23 July 2011 


\title{
Chapter 3
}

Molecular-level characterization of dissolved organic matter associated with the Greenland ice sheet*

\begin{abstract}
Subsurface microbial oxidation of overridden soils and vegetation beneath glaciers and ice sheets may affect global carbon budgets on glacial-interglacial timescales. The likelihood and magnitude of this process depends on the chemical nature and reactivity of the subglacial organic carbon stores. We examined the composition of carbon pools associated with different regions of the Greenland ice sheet (subglacial, supraglacial, proglacial) in order to elucidate the type of dissolved organic matter (DOM) present in the subglacial discharge over a melt season. Electrospray ionization (ESI) Fourier transform ion cyclotron resonance (FT-ICR) mass spectrometry coupled to multivariate statistics permitted unprecedented molecular level characterization of this material and revealed that carbon pools associated with discrete glacial regions are comprised of different compound classes. Specifically, a larger proportion of protein-like compounds were observed in the supraglacial samples and in the early melt season (spring) subglacial discharge. In contrast, the late melt season (summer) subglacial discharge contained a greater fraction of lignin-like and other material presumably derived from underlying vegetation and soil. These results suggest (1) that the majority of supraglacial DOM originates from autochthonous microbial processes on the ice sheet surface, (2) that the subglacial DOM contains allochthonous carbon derived from overridden soils and vegetation as well as autochthonous carbon derived from in situ microbial metabolism, and (3) that the relative contribution of allochthonous and autochthonous material in subglacial discharge varies during the melt season. These conclusions are consistent with the hypothesis that, given sufficient time (e.g., overwinter storage), resident subglacial microbial communities may oxidize terrestrial material beneath the Greenland ice sheet.
\end{abstract}

* Published as: Bhatia, M., S.B. Das, K.L. Longnecker, M.A. Charette, and E.B. Kujawinski (2010). Molecular-level characterization of dissolved organic matter associated with the Greenland ice sheet, Geochimica et Cosmochimica Acta, 74(2010): 3468-3784. 


\title{
Molecular characterization of dissolved organic matter associated with the Greenland ice sheet
}

\author{
Maya P. Bhatia ${ }^{a}$, Sarah B. Das ${ }^{b}$, Krista Longnecker ${ }^{c}$, Matthew A. Charette ${ }^{\text {, }}$ \\ Elizabeth B. Kujawinski ${ }^{\mathrm{c}, *}$ \\ ${ }^{a}$ MIT/WHOI Joint Program in Oceanography/Applied Ocean Sciences and Engineering, Department of Geology and Geophysics, \\ Woods Hole Oceanographic Institution, Woods Hole, MA 02543, USA \\ ${ }^{\mathrm{b}}$ Department of Geology and Geophysics, Woods Hole Oceanographic Institution, Woods Hole, MA 02543, USA \\ ${ }^{\mathrm{c}}$ Department of Marine Chemistry and Geochemistry, Woods Hole Oceanographic Institution, Woods Hole, MA 02543, USA
}

Received 3 November 2009; accepted in revised form 9 March 2010; available online 7 April 2010

\begin{abstract}
Subsurface microbial oxidation of overridden soils and vegetation beneath glaciers and ice sheets may affect global carbon budgets on glacial-interglacial timescales. The likelihood and magnitude of this process depends on the chemical nature and reactivity of the subglacial organic carbon stores. We examined the composition of carbon pools associated with different regions of the Greenland ice sheet (subglacial, supraglacial, proglacial) in order to elucidate the type of dissolved organic matter (DOM) present in the subglacial discharge over a melt season. Electrospray ionization (ESI) Fourier transform ion cyclotron resonance (FT-ICR) mass spectrometry coupled to multivariate statistics permitted unprecedented molecular level characterization of this material and revealed that carbon pools associated with discrete glacial regions are comprised of different compound classes. Specifically, a larger proportion of protein-like compounds were observed in the supraglacial samples and in the early melt season (spring) subglacial discharge. In contrast, the late melt season (summer) subglacial discharge contained a greater fraction of lignin-like and other material presumably derived from underlying vegetation and soil. These results suggest (1) that the majority of supraglacial DOM originates from autochthonous microbial processes on the ice sheet surface, (2) that the subglacial DOM contains allochthonous carbon derived from overridden soils and vegetation as well as autochthonous carbon derived from in situ microbial metabolism, and (3) that the relative contribution of allochthonous and autochthonous material in subglacial discharge varies during the melt season. These conclusions are consistent with the hypothesis that, given sufficient time (e.g., overwinter storage), resident subglacial microbial communities may oxidize terrestrial material beneath the Greenland ice sheet.
\end{abstract}

(C) 2010 Elsevier Ltd. All rights reserved.

\section{INTRODUCTION}

Anticipating how carbon flux patterns might respond to climate change is a principal motivation for understanding the different sources and reservoirs contributing to the global carbon cycle. In aquatic systems, carbon flux patterns

\footnotetext{
${ }^{*}$ Corresponding author. Address: Department of Marine Chemistry and Geochemistry, Woods Hole Oceanographic Institution, 360 Woods Hole Rd. MS\#4, Woods Hole, MA 02543, USA. Tel.: +15082893493.

E-mail address: ekujawinski@whoi.edu (E.B. Kujawinski).
}

result from complex metabolic interactions of diverse biota with a pool of organic matter (Azam, 1998). Previously it was believed that glacial environments were devoid of life and thus, that carbon dynamics in these systems should be dominated by abiotic processes (Raiswell, 1984; Chillrud et al., 1994). However, the recent discovery of large, active microbial communities beneath glaciers and ice sheets has enlightened our understanding of biogeochemical reactions and organic carbon cycling in glaciated regions, namely that subglacial microbial communities may play an active role in the carbon cycle through oxidation of organic carbon stores beneath ice masses (Sharp et al., 1999; Tranter 
et al., 2002; Lanoil et al., 2009). On glacial-interglacial timescales, microbial activity might provide an important source of acidity to fuel chemical weathering of silicate rocks, a long-term control on atmospheric $\mathrm{CO}_{2}$ levels (Berner et al., 1983; Brown, 2002). In addition, microbes may respire or ferment soil organic carbon (to $\mathrm{CO}_{2}$ or to $\mathrm{CH}_{4}$, respectively), previously considered inert until deglaciation (Sharp et al., 1999). Wadham et al. (2008) estimated that between 418 and $610 \mathrm{Pg}$ of organic carbon was present beneath ice sheets during the last glacial period, of which 63 $\mathrm{Pg} \mathrm{C}$ was available for conversion to methane over a glacial cycle. Additionally, Skidmore et al. (2000) calculated that aerobic respiration of subglacial organic carbon could convert $8.1 \mathrm{Pg} \mathrm{C}$ to carbon dioxide over a glacial cycle. These calculations, however, are constrained by a lack of knowledge concerning the availability of the subglacial organic carbon stores to microbial degradation. This is a potentially large limitation, given the range in biological reactivity within all other organic carbon stores (Hedges et al., 2000; Eglinton and Repeta, 2003). In order to examine the impact of microbial oxidation on subglacial organic carbon stores, it is critical to assess the composition and reactivity of this material.

Carbon is derived from two distinct regions of the glacial environment: (1) on the glacier surface (i.e., the supraglacial environment) from inorganic and organic carbon in snow and ice; and (2) at the glacier base (i.e., the subglacial environment) where carbon is derived from the underlying bedrock, sediments, and ice. These two regions are linked by a hydrological network that becomes activated during the summer melt season when accumulated surface meltwaters drain through crevasses, moulins, and englacial channels to the bed (e.g. Nienow et al., 1998; Das et al., 2008). Once at the bed, the supraglacial meltwaters become connected to a broad subglacial hydrological drainage network, in contact with the underlying till and bedrock (Nienow et al., 1998). Generally, dissolved organic carbon (DOC) concentrations in supraglacial snow and meltwater are very low $(\sim 10-40 \mu \mathrm{M})$ (Lafreniere and Sharp, 2004; Lyons et al., 2007). In contrast, available organic carbon sources in subglacial environments have variable DOC concentrations ranging from 60 to $700 \mu \mathrm{M}$ as reflected in subglacial outflow waters (Lafreniere and Sharp, 2004; Skidmore et al., 2005) and concentrations up to $\sim 4 \mathrm{mM}$ (Dry Valleys, Antarctica) and $\sim 20 \mathrm{mM}$ (Ellesmere Island, Canada) in basal ice samples (Barker et al., 2006; Bhatia et al., 2006). Although measurements are limited, this variability observed among subglacial DOC concentrations is likely a function of sampling time and/or of different physical characteristics (e.g. lithologies, sediment content, proximity to land) between and within specific field sites.

While bulk DOC abundance studies are useful as firstorder investigations, they offer little information regarding the provenance, reactivity and bioavailability of the glacial organic carbon pools. In an effort to address these issues, Lafreniere and Sharp (2004) and Barker et al. (2006) used spectrofluorometric techniques to distinguish subglacial fulvic acids (the portion of humic material which is water-soluble at any $\mathrm{pH}$ ) derived from terrestrial precursor material from those of microbial origin. Terrestrially derived dis- solved organic matter (DOM) would contain fulvic acids from plant and soil organic matter, which are typically more aromatic, due to the presence of compounds such as lignins (McKnight et al., 2001). Alternatively, microbiallyderived DOM would contain fulvic acids from microbial cell components and metabolism, and are typically less aromatic (McKnight et al., 1994; McKnight et al., 2001). Both Lafreniere and Sharp (2004) and Barker et al. (2006) found that supraglacial samples contained microbially-derived fulvic acids, which they attributed to primary productivity of algae and bacteria in the snow, ice, and meltwater on the glacial surface. However, results from the subglacial runoff were more variable, with both studies finding sources of fulvic acids with both microbial and terrestrial provenance. These findings were attributed to changing subglacial flow-routing regimes throughout the melt season that access different carbon pools as well as to in situ subglacial microbial metabolisms that alter the subglacial carbon pools.

Though an important first step in compositional assessment of glacial organic carbon pools, fluorescence spectroscopy studies are limited because (1) they can only assess one fraction of DOM (fulvic acids), and (2) they do not directly identify the presence of specific compounds within the DOM pool, thus permitting only broad distinctions between 'microbial' and 'terrestrial' components. In contrast, electrospray ionization (ESI) coupled to Fourier transform ion cyclotron resonance mass spectrometers (FT-ICR MS) provides an opportunity to study a larger portion of the DOC pool (intact polar molecules), and to characterize the reactivity of specific molecules in biogeochemical processes. ESI is a 'soft' (low-fragmentation) ionization technique that detects polar molecules with acidic and basic functional groups. When coupled to a mass spectrometer, such as FT-ICR MS which is capable of ultrahigh mass resolution $(>100,000)$ and mass accuracy $(<1 \mathrm{ppm})$, tens of molecules can be accurately resolved at each nominal mass (Kujawinski, 2002; Marshall and Rodgers, 2008). The mass accuracy achievable is the key to this technique as it enables the assignment of elemental formulae solely from the mass measurement (Kim et al., 2006; Kujawinski and Behn, 2006). Therefore, ESI FT-ICR MS can be used to identify compositional differences among pools of DOM, as well as to determine the elemental compositions of specific molecules within DOM. Recently, ESI FT-ICR MS has been utilized to characterize DOM in a range of diverse environments, including freshwater systems (Sleighter and Hatcher, 2008), marine systems (Koch et al., 2005), and ice cores (Grannas et al., 2006).

The goal of this study was to investigate the compositional nature of carbon pools associated with different regions of the Greenland ice sheet in order to elucidate the type of dissolved organic matter present in the subglacial discharge over a melt season. The carbon pools explored were (1) the supraglacial environment: snow and meltwater on the ice surface, (2) the subglacial environment: water exiting the base of a land-terminating outlet glacier, and (3) the proglacial tundra environment: non-glacially derived pond water. From a hydrological perspective, these environments are serially connected to each other as the 
majority of the supraglacial meltwater on a glacier surface penetrates to the subglacial environment and eventually exits into the proglacial environment. Thus, the compositional characteristics of the contributing carbon pools as well as physical and microbial processes en route ultimately dictate the composition of the DOM in the subglacial discharge. We employed ESI FT-ICR MS to detect compositional differences among the different carbon pools sampled, and to gain insight into the molecular-level impact of microbial metabolism on subglacial organic carbon. By establishing baseline values of the type of organic carbon present beneath glaciated areas, this study serves as the foundation for broader investigations into the impact of increased meltwater runoff from the Greenland ice sheet to surrounding marine environments, and into the extent of subglacial microbial oxidation of overridden soils and vegetation.

\section{METHODS}

\subsection{Field sites}

This study was conducted at two locations along the western margin of the Greenland ice sheet in 2007 and 2008. In July 2007 two snow samples and one supraglacial meltwater sample were collected from the ablation zone on the ice sheet surface, at $980-\mathrm{m}$ elevation approximately $40 \mathrm{~km}$ inland from the edge of the ice sheet (Fig. 1). By July most of the seasonal snow deposited the previous winter had already melted, thus our samples were collected from isolated pockets of heavily metamorphosed and colored snow from drifts along the banks of relict stream channels. Of the two snow samples analyzed for this study, one exhibited a yellow and green hue (Yellow Snow) and the other a red and black hue (Red Snow). The supraglacial meltwater sample (Supraglacial Inland) was collected from the edge of a large meltwater lake ( $\sim 1 \mathrm{~km}$ in diameter). Given the scarcity of seasonal snow on the ice sheet surface during our sampling period, and the high annual ablation rates we measured at this site $\left(\sim 2-\mathrm{m}\right.$ ice melt $\left.\mathrm{yr}^{-1}\right)$, this meltwater sample is assumed to be derived almost entirely from glacial ice melt rather than from seasonal snow melt or rainfall.

In May and July 2008, samples were collected in the vicinity of a small land-terminating outlet glacier (named glacier 'N' here), approximately $70 \mathrm{~km}$ south of the 2007 site (Fig. 1). In May, one sample was collected from a small supraglacial meltwater pond ( $\sim 20 \mathrm{~m}$ in diameter) within $1 \mathrm{~km}$ of the ice sheet margin (Supraglacial Margin). The water here consisted primarily of snow and ice melt. A second sample was collected from the subglacial stream exiting at the base of glacier 'N' (Subglacial May). A third sample was collected at a proglacial pond (Tarn). In July, two additional samples were collected from the subglacial stream exiting the base of glacier 'N' (Subglacial July-1 and Subglacial July-2, referred to collectively as Subglacial July). A synopsis of the samples collected in this study and the filtration and extraction procedures (details below) is presented in Table 1. Electrical conductivity (EC) measurements were made on-site using a Russell RL060C meter (Thermo Electron) for the Subglacial May and July and
Supraglacial Margin samples, and are also presented in Table 1.

\subsection{Sample collection and filtration}

The snow samples were collected aseptically using sterile plastic bags (WhirlPak; Nasco Products), and melted onsite in a warm water bath; conditions in the field precluded melting the samples at a controlled $4{ }^{\circ} \mathrm{C}$. The water samples were collected in either combusted glass or acid-cleaned Teflon bottles. All samples were filtered on-site through $0.2-\mu \mathrm{m}$ filters prior to extraction, except for the Red Snow sample, which was processed back in the laboratory. Most samples (Yellow Snow, Supraglacial Inland, Supraglacial Margin, Subglacial May, Tarn) were filtered using $0.2-\mu \mathrm{m}$ Sterivex cartridges (Millipore), that had been pre-cleaned by soaking in a $10 \% \mathrm{HCl}$ bath for at least one day, followed by rinsing with $20 \mathrm{~L}$ of Milli-Q water. The background DOC concentration of the pre-cleaned units was approximately $9 \mu \mathrm{M}$. Due to limited availability of pre-cleaned Sterivex units in the field, the remaining samples (Red Snow, Subglacial July-1, Subglacial July-2) were filtered through a combusted GFF (Whatman) pre-filter and a combusted 0.2- $\mu \mathrm{m}$ Anodisc membrane (Whatman). All solvents were purchased from Thermo Fisher Scientific (Waltham, MA) and were Optima grade or better. Concentrated $\mathrm{HCl}$ was Trace-Metal grade. The final volumes of $0.2-\mu \mathrm{m}$ filtrate (Table 1) differed to accommodate a range of anticipated DOC contents as well as the difficulties encountered with filtering some samples (for example, Subglacial May contained a significant amount of rock flour that quickly clogged the filters). An aliquot of the $0.2-\mu \mathrm{m}$ filtrate was acidified and stored in a combusted vial for DOC analysis.

\subsection{Solvent extraction}

Immediately following $0.2-\mu \mathrm{m}$ filtration, all samples were acidified to $\mathrm{pH} 3$ with $12 \mathrm{M} \mathrm{HCl}$ and dissolved organic matter (DOM) was extracted with either $\mathrm{C}_{18}$ cartridges (Mega Bond Elut, UTC) or $\mathrm{C}_{18}$ extraction discs (3 M) (Table 1). All of the solvent extractions except for the Subglacial July and Red Snow samples were done on-site. The Subglacial July and Red Snow samples were kept as cold as possible, and extracted approximately two months later. The solvent extraction protocol employed was modified from Kim et al. (2003b). Briefly, the cartridges or discs were pre-cleaned according to manufacturer's instructions. The acidified sample was then passed through the cleaned cartridge/disc and the cartridge/disc was left to dry for 15 min prior to solvent extraction with methanol $(\mathrm{MeOH})$ (Table 1). Extracts were evaporated to dryness under vacuum at $30^{\circ} \mathrm{C}$. For Red Snow, the $70 \%$ and $100 \% \mathrm{MeOH}$ aliquots were combined prior to vacuum evaporation. A procedural blank $(\mathrm{MeOH})$ was also evaporated to dryness under vacuum. The samples and solvent blank were stored dry at $-20{ }^{\circ} \mathrm{C}$ until further analysis. We estimated our DOM extraction efficiency by drying an aliquot of the solvent extract on a pre-weighed combusted GFF, and measuring the carbon by dynamic flash combustion on a ThermoQuest EA1112 Carbon/Nitrogen Analyzer. The 


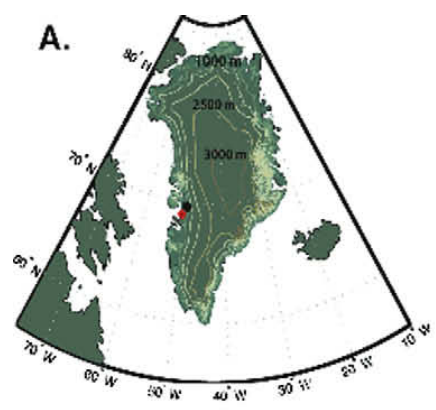

B.
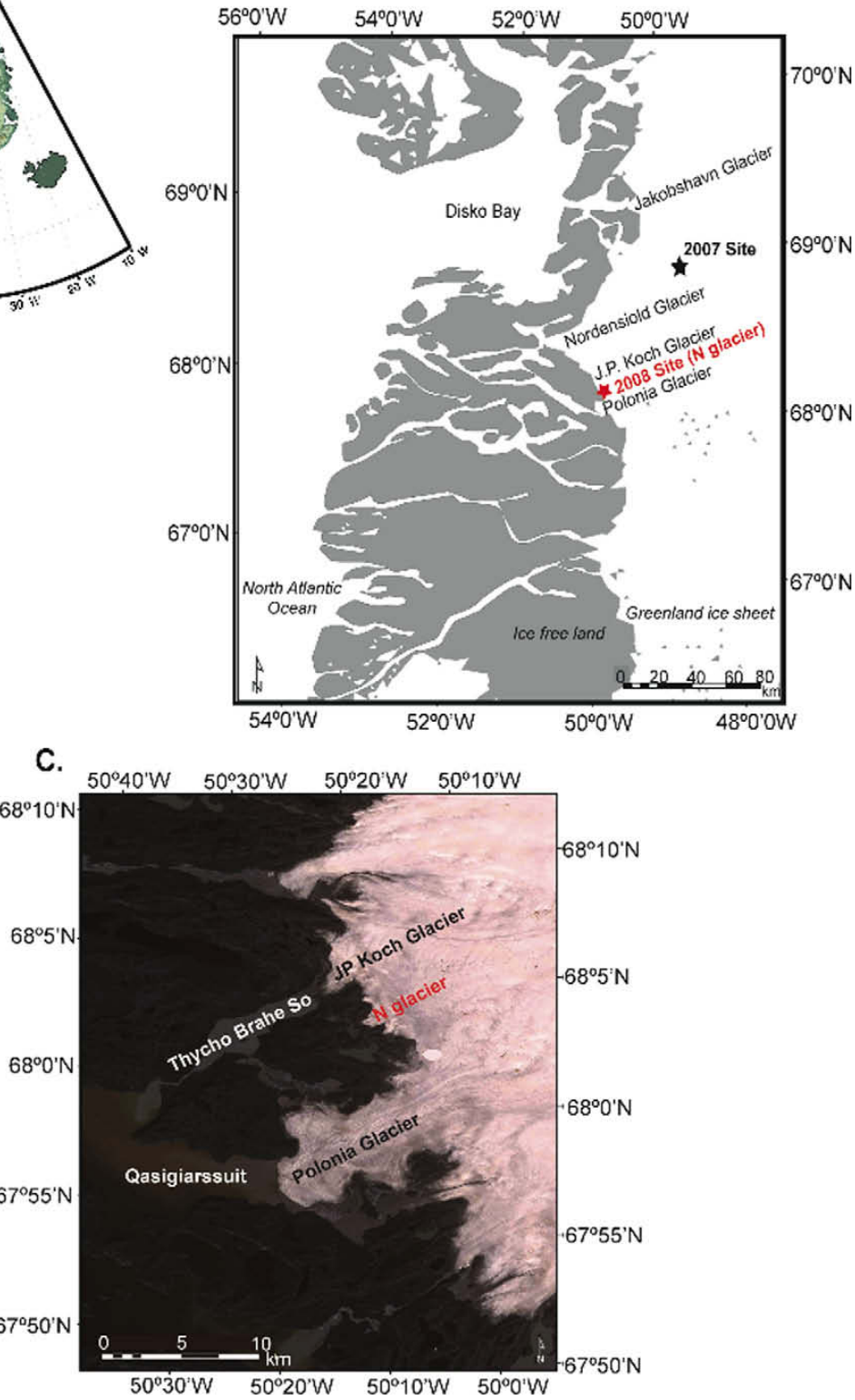

Fig. 1. Locations of the 2007 and 2008 sample sites. (A) A map of Greenland, with the black circle representing the 2007 field site and the red circle representing the 2008 field site. The green contour lines represent the surface elevation (5-km DEM from Bamber et al., 2001; Layberry and Bamber, 2001). (B) An expanded image of the two field sites. The 2007 ice surface field site is $\sim 40 \mathrm{~km}$ inland from the ice sheet edge, and approximately $70 \mathrm{~km}$ north of the 2008 field site, located at the glacier margin. (C) A Landsat image of the 2008 ice marginal sample location (named ' $\mathrm{N}$ ' glacier in this study). (For interpretation of the references to colour in this figure legend, the reader is referred to the web version of this article.)

extraction efficiency for each sample was calculated as the percent of carbon recovered from the solvent extract relative to the total amount of carbon in the sample (as determined by TOC analysis). The extraction efficiencies (Table 1) ranged from $10 \%$ to $94 \%$, with a mean of $44 \%$ and a median of $28 \%$. Although we obtained a low extrac- tion efficiency ( $10 \%)$ for the Subglacial July-2 sample, we do not anticipate being limited in our conclusions since this sample is duplicated by Subglacial July-1 and the mass spectral characteristics of the two samples are nearly identical (see Section 3.2 and Fig. 3). The Tarn sample was the one most similar to previously described freshwater 
Table 1

Synopsis of the samples collected in this study in preparation for DOM extraction and mass spectrometry analysis. $(*)-$ The [DOC] reported for Subglacial July-1 is from a sample collected $6 \mathrm{~h}$ prior to the sample analyzed for DOM composition in this study. N/A = data not available.

\begin{tabular}{|c|c|c|c|c|c|c|c|c|c|}
\hline Region & Sample & $\begin{array}{l}\text { Collection } \\
\text { date }\end{array}$ & Location & $\begin{array}{l}\text { Volume } \\
\text { filtered }\end{array}$ & $\begin{array}{l}\mathrm{C}_{18} \mathrm{DOM} \\
\text { extraction }\end{array}$ & $\begin{array}{l}\text { Solvent } \\
\text { extract }\end{array}$ & $\begin{array}{l}\text { DOC } \\
\text { concentration }(\mu \mathrm{M})\end{array}$ & $\begin{array}{l}\text { Electrical } \\
\text { conductivity } \\
\left(\mu \mathrm{S} / \mathrm{cm}^{3}\right)\end{array}$ & $\begin{array}{l}\text { Extraction } \\
\text { efficiencies } \\
(\%)\end{array}$ \\
\hline Snow & $\begin{array}{l}\text { Yellow } \\
\text { Snow }\end{array}$ & $\begin{array}{l}\text { July } 17 \\
2007\end{array}$ & $68^{\circ} 33^{\prime} \mathrm{N} 49^{\circ} 23^{\prime} \mathrm{W}$ & $2 \mathrm{~L}$ & Cartridge & $\begin{array}{l}40 \mathrm{~mL} \\
100 \% \\
\mathrm{MeOH}\end{array}$ & N/A & N/A & N/A \\
\hline Snow & Red Snow & $\begin{array}{l}\text { July } 17 \\
2007\end{array}$ & $68^{\circ} 34^{\prime} \mathrm{N} 49^{\circ} 22^{\prime} \mathrm{W}$ & $87 \mathrm{~mL}$ & Discs & $\begin{array}{l}5 \mathrm{~mL} \\
70 \% \\
5 \mathrm{~mL} \\
100 \% \\
\mathrm{MeOH}\end{array}$ & N/A & N/A & N/A \\
\hline Supraglacial & $\begin{array}{l}\text { Supraglacial } \\
\text { Inland }\end{array}$ & $\begin{array}{l}\text { July } 14 \\
2007\end{array}$ & $68^{\circ} 34^{\prime} \mathrm{N} 49^{\circ} 21^{\prime} \mathrm{W}$ & $15 \mathrm{~L}$ & Cartridge & $\begin{array}{l}40 \mathrm{~mL} \\
100 \% \\
\mathrm{MeOH}\end{array}$ & N/A & N/A & N/A \\
\hline Supraglacial & $\begin{array}{l}\text { Supraglacial } \\
\text { Margin }\end{array}$ & $\begin{array}{l}\text { May } 31 \\
2008\end{array}$ & $68^{\circ} 02^{\prime} \mathrm{N} 50^{\circ} 15^{\prime} \mathrm{W}$ & $4 \mathrm{~L}$ & Cartridge & $\begin{array}{l}15 \mathrm{~mL} \\
100 \% \\
\mathrm{MeOH}\end{array}$ & $16 \pm 0.7$ & 0.2 & 28 \\
\hline Subglacial & $\begin{array}{l}\text { Subglacial } \\
\text { May }\end{array}$ & $\begin{array}{l}\text { May } 31 \\
2008\end{array}$ & $68^{\circ} 02^{\prime} \mathrm{N} 50^{\circ} 16^{\prime} \mathrm{W}$ & $500 \mathrm{~mL}$ & Cartridge & $\begin{array}{l}15 \mathrm{~mL} \\
100 \% \\
\mathrm{MeOH}\end{array}$ & $28 \pm 0.2$ & 17 & 94 \\
\hline Proglacial & Tarn & $\begin{array}{l}\text { May } \\
292008\end{array}$ & $68^{\circ} 02^{\prime} \mathrm{N} 50^{\circ} 17^{\prime} \mathrm{W}$ & $1 \mathrm{~L}$ & Cartridge & $\begin{array}{l}15 \mathrm{~mL} \\
100 \% \\
\mathrm{MeOH}\end{array}$ & $406 \pm 3$ & N/A & 57 \\
\hline Subglacial & $\begin{array}{l}\text { Subglacial } \\
\text { July-1 }\end{array}$ & $\begin{array}{l}\text { July } \\
122008\end{array}$ & $68^{\circ} 02^{\prime} \mathrm{N} 50^{\circ} 16^{\prime} \mathrm{W}$ & $4.5 \mathrm{~L}$ & Cartridge & $\begin{array}{l}15 \mathrm{~mL} \\
100 \% \\
\mathrm{MeOH}\end{array}$ & $* 15 \pm 0.4$ & 3.2 & 28 \\
\hline Subglacial & $\begin{array}{l}\text { Subglacial } \\
\text { July-2 }\end{array}$ & $\begin{array}{l}\text { July } \\
162008\end{array}$ & $68^{\circ} 02^{\prime} \mathrm{N} 50^{\circ} 16^{\prime} \mathrm{W}$ & $3.45 \mathrm{~L}$ & Cartridge & $\begin{array}{l}15 \mathrm{~mL} \\
100 \% \\
\mathrm{MeOH}\end{array}$ & $51 \pm 0.3$ & 2.3 & 10 \\
\hline
\end{tabular}

samples and the extraction efficiency of this sample $(60 \%)$ is well within the range documented to other freshwater studies (Kim et al., 2003b; Dittmar et al., 2008).

\subsection{DOC concentrations}

Total and dissolved organic carbon (TOC, DOC) concentrations were quantified as non-purgeable organic carbon (NPOC) by high temperature combustion $\left(680^{\circ} \mathrm{C}\right)$ with a Shimadzu TOC- $\mathrm{V}_{\mathrm{CSH}}$ analyzer equipped with a high sensitivity platinum catalyst (Shimadzu Scientific Instruments). Samples were quantified using a 5-point standard curve made with potassium hydrogen phthalate (KHP). Blanks and reference standards were analyzed routinely within each sample run. Reference standards for low carbon water and deep-sea water were obtained from the Consensus Reference Materials Project, Hansell Laboratory, University of Miami. DOC was not quantified for the 2007 samples due to post-acquisition contamination in Greenland.

\subsection{FT-MS data acquisition}

All samples and the solvent blank were analyzed on a 7-T ESI FT-ICR mass spectrometer (LTQ-FT-MS, Thermo Fisher Scientific, Waltham, MA). For positive ion mode analyses, sample aliquots were reconstituted in $80 \% \mathrm{MeOH}$ with $0.1 \%$ acetic acid (final concentration). Acetic acid promoted positive ion formation. For negative ion mode analyses, reconstituted sample aliquots were reconstituted in $70 \% \mathrm{MeOH}$. The solvents used to dilute the samples were also analyzed as instrument blanks $(100 \% \mathrm{MeOH}$ in positive ion mode and $70 \% \mathrm{MeOH}$ in negative ion mode).

For both positive and negative ion modes, samples were infused into the ESI interface at $4 \mu \mathrm{L} \mathrm{min}^{-1}$, and instrument parameters were optimized for each sample. Samples were diluted to optimize spray conditions; dilutions ranged from 1:5 to 1:40. The capillary temperature was set at $250{ }^{\circ} \mathrm{C}$, and the spray voltage varied between 4.40 and $4.60 \mathrm{kV}$. About 200 scans were collected for each sample, a sufficient number of scans for peak reproducibility in our samples. The mass ranges for full-scan collection were $200<m / z<1200$ and $200<m / z<1000$ in positive and negative ion modes, respectively. Weekly mass calibrations were performed with an external standard (Thermo Calibration Mix), and resulted in mass accuracy errors $<1 \mathrm{ppm}$. The target average resolving power was 400,000 at $\mathrm{m} / \mathrm{z} 400$ (where resolving power is defined as $\mathrm{m} / \Delta \mathrm{m}_{50 \%}$ where $\Delta \mathrm{m}_{50 \%}$ is the width at half-height of peak m). Good quality data could not be collected for the Subglacial July-2 sample in positive ion mode, nor for the Red Snow sample in negative ion mode. This was due to unacceptable spray stabilities in the former and fluctuating ion currents in the latter. 


\subsection{FT-MS data analysis}

\subsubsection{Peak detection and blank correction}

We collected individual transients as well as a combined raw file using $x$ Calibur 2.0. Transients were co-added and processed with custom-written MATLAB code provided by Southam et al. (2007). This code was used as provided with the following parameters. Within each sample, only those transients whose total ion current (TIC) was greater than $20 \%$ of the maximal TIC were co-added and then processed with Hanning apodisation, and zero-filled once prior to fast Fourier transformation. We retained all $\mathrm{m} / \mathrm{z}$ values with a signal-to-noise ratio above 5 (as calculated in Southam et al. (2007)). The individual sample and solvent blank peak lists were then aligned using MATLAB code provided by Mantini et al. (2007). Positive and negative ion mode data were aligned separately in MATLAB with an error tolerance of $1 \mathrm{ppm}$. Following alignment, all peaks found in each mode's solvent blanks were removed from the appropriate master list. These blank-corrected master peak lists in each sample were used in all downstream statistical analyses and elemental formula assignments.

\subsubsection{Calibration}

Positive and negative ion mode spectra were internally re-calibrated using a short list of $\mathrm{m} / \mathrm{z}$ values present in a majority of samples. This list of calibrants was chosen according to the following criteria: (1) presence in the majority of samples; (2) elemental formulae could be assigned with $\mathrm{C}, \mathrm{H}, \mathrm{O}$ and $\mathrm{N}$; (3) similar mass errors for all; and (4) distribution along the $m / z$ range of each spectrum. The resulting calibrants and their elemental formulae are provided in EA Table 1a and b. After internal re-calibration, the root mean square (RMS) errors for the calibrants ranged from 0.09 to 0.12 in positive ion mode and 0.04 to 0.69 in negative ion mode.

\subsubsection{Elemental formula assignments}

Elemental formulae were assigned to the aligned blankcorrected peaks ( $\mathrm{m} / \mathrm{z}$ values) using the Compound Identification Algorithm (CIA), described by Kujawinski and Behn (2006) and modified in Kujawinski et al. (2009). In the CIA, we set the following parameters: (a) formula error was $1 \mathrm{ppm}$, (b) the relationship error was $20 \mathrm{ppm}$, and (c) the mass limit above which elemental formulae were only assigned by functional group relationships was $500 \mathrm{Da}$. For this study, elemental formulae were determined for $\mathrm{m} / \mathrm{z}$ values below $500 \mathrm{Da}$ by comparison to an in-house database of mathematically and chemically legitimate formulae within the $1 \mathrm{ppm}$ error window. Elemental formula assignments were constrained to ${ }^{12} \mathrm{C},{ }^{13} \mathrm{C},{ }^{1} \mathrm{H},{ }^{16} \mathrm{O},{ }^{14} \mathrm{~N},{ }^{34} \mathrm{~S}$, and ${ }^{31} \mathrm{P}$. Error testing for formula assignments containing these elements was done using synthetic datasets and is documented in Kujawinski and Behn (2006). Accuracy of formula assignments ranges from $78 \%$ to $100 \%$, depending on included elements (Kujawinski and Behn, 2006). These elemental formulae were extended to $\mathrm{m} / \mathrm{z}$ values above $500 \mathrm{Da}$ through identification of functional group relationships. The functional group relationships used by CIA are common to refractory dissolved organic matter (e.g. humic acids); CIA does not presently include many functional group relationships resulting from metabolic (biological) reactions (Kujawinski and Behn, 2006). Isotopomers with a ${ }^{13} \mathrm{C}$ atom are identified in the last step of CIA and elemental formulae are corrected to reflect ${ }^{13} \mathrm{C}$ content. In order to identify terrestrially-derived components of our samples, we compared the elemental formulae for our Greenland samples with those assigned to Suwannee River Fulvic Acid Standard I (Suwannee River - International Humic Substances Society, Stock \#1S101F), previously analyzed in our laboratory with negative ion mode ESI FT-ICR MS. Magnitude-averaged elemental ratios and double bond equivalencies were calculated (Sleighter and Hatcher, 2008).

\subsubsection{Assessment of potential contamination}

Analysis of the negative and positive ion mode mass spectra revealed potential contamination likely originating from plasticizers or the $\mathrm{C}_{18}$ extraction cartridges/discs. In negative ion mode, potential contamination was most prevalent in the Yellow Snow sample. We assigned elemental formulae to the contaminated $\mathrm{m} / \mathrm{z}$ values (18 peaks) and identified peaks belonging to this series in other negative ion mode spectra. Contaminated peaks did not occupy any particular region of the van Krevelen diagram (EA Fig. 1). We realize that any contamination may skew the overall composition of the DOM through ion suppression; nonetheless, we believe we attained an adequate representation of DOM composition within our samples because the maximum percentage of peaks represented by the suspected plasticizer contamination was less than $0.6 \%$ in any one sample. In addition, to further minimize the potential impact of this contamination, we based our statistical analyses and subsequent conclusions on the diversity of resolved peaks (presence/absence) rather than on their relative peak heights. In positive ion mode, the potential contamination was more pervasive. Inspection of the raw mass spectra revealed likely contamination in the Yellow Snow, Subglacial May, and Tarn samples. Given this observation, we focused our statistical analyses and interpretations on the negative ion mode dataset.

\subsubsection{Multivariate statistics}

We assessed differences in our samples in negative ion mode with cluster analysis as described in Kujawinski et al. (2009). In our analysis, we transformed all relative peak heights to presence (peak height $=1$ ) or absence (peak height $=0$ ). We recognize that ESI is not quantitative and that differences in ionization efficiencies among compounds can lead to misrepresentations of ion peak height, relative to the abundance of the parent molecule in neutral solution (Stenson et al., 2003). To circumvent this known problem, we have used presence/absence comparisons rather than those that rely on relative peak height.

The presence/absence transformation allows assessment of how samples differ based solely on peak diversity. A distance matrix was calculated between all the samples in each mode using the Bray-Curtis distance measure (MATLAB code written by David Jones, University of Miami, as part of the Fathom toolbox); a distance measure of 0 indicates samples are identical with regards to peak diversity, 
whereas a distance measure of 1 indicates that samples share none of their peaks. Ward's linkage method was used to group the samples followed by presentation of the results as a dendrogram.

\subsubsection{Indicator species analysis}

We identified specific $\mathrm{m} / \mathrm{z}$ values characteristic of the observed negative ion mode cluster groupings with indicator species analysis (ISA - as implemented in Kujawinski et al., 2009). ISA combines the relative abundance and relative frequency of a peak within a pre-defined group of samples to assign an indicator value (IV) to each peak (McCune and Grace, 2002). A perfect IV (equal to 100) of a particular group would constitute an $\mathrm{m} / \mathrm{z}$ value that was present exclusively in the samples comprising that group (McCune and Grace, 2002). Statistical significance of IVs is calculated by comparison with Monte-Carlo simulations of randomized data. ISA requires a priori assignment of samples to groups; this was achieved using the protocol and criteria described in McCune and Grace (2002). The best number of groups occurred when we used four groups of samples: Group $1=$ Yellow Snow; Group $2=$ Supraglacial Inland; Group 3 = 'N' glacier May samples (Subglacial May and Supraglacial Margin); and Group $4={ }^{\text {N' }}$ ' glacier July and Tarn samples (Subglacial July-1, 2 and Tarn). This group assignment was used to find indicator $m / z$ values for Groups 3 and 4; use of ISA is restricted to those groups with more than one sample, thus no 'indicator peaks' were identified for Groups 1 and 2. The final list of indicator $\mathrm{m} / \mathrm{z}$ values for each group was manually curated using the criteria outlined in Kujawinski et al. (2009).

\section{RESULTS AND DISCUSSION}

\subsection{Sample overview}

The eight samples analyzed in this study represent carbon pools associated with different regions of a glacier sys- tem. The supraglacial pools are represented by snow (Yellow Snow, Red Snow) and meltwater (Supraglacial Inland) samples from the inland ice surface as well as the meltwater sample collected on the surface of ' $\mathrm{N}$ ' glacier (Supraglacial Margin). The subglacial pool at the glacier base is represented by samples collected from the subglacial stream exiting at the base of 'N' glacier (Subglacial May, Subglacial July-1, 2). Since surface ice melting is minimal in May, the Subglacial May water sample most likely represents early/spring discharge waters that have been stored at the bed overwinter. These waters likely drain a more distributed subglacial hydrological system with relatively slower flow rates, but they may access a greater areal extent of the subglacial bed (Nienow et al., 1998; Sharp et al., 1999). Conversely, the July subglacial water samples represent late/summer discharge waters fed primarily by supraglacial inflow. These waters likely drain through a channelized hydrological system characterized by relatively much higher flow rates, but they may access a more limited part of the bed (Bingham et al., 2005; Nienow et al., 1998). The electrical conductivity (EC) measurements (Table 1) support this interpretation. The Subglacial May sample has a greater content of dissolved solutes compared to the Subglacial July samples. Finally, a proglacial tarn (Tarn) represents a terrestrial carbon end-member, comprised of non-glacial water, situated in the deglaciated arctic tundra and likely containing a large terrestrial contribution from the surrounding vegetation.

\subsection{Comparison of ultra-high resolution mass spectra}

All of the samples contained highly complex DOM with numerous peaks per nominal mass in both positive and negative ion modes. The total numbers of peaks resolved in each sample in negative ion mode following blank correction are presented in Table 2. Qualitative differences among the raw mass spectra illustrate that samples representing different regions of the Greenland ice sheet have distinct

Table 2

Synopsis of general parameters regarding negative ion mode formula assignments. Elemental ratios were calculated as magnitude-averaged values (Sleighter and Hatcher, 2008) for $\mathrm{m} / \mathrm{z}$ values with assigned elemental formulae.

\begin{tabular}{|c|c|c|c|c|c|c|c|c|c|c|c|c|}
\hline Sample & $\begin{array}{l}\text { Total } \\
\text { number } \\
\text { of peaks }\end{array}$ & $\begin{array}{l}\text { Number } \\
\text { of } \\
\text { formulas } \\
\text { assigned }\end{array}$ & $\begin{array}{l}\% \\
\text { Formulas } \\
\text { assigned }\end{array}$ & $\mathrm{H}: \mathrm{C}_{\mathrm{w}}$ & $\mathrm{O}: \mathrm{C}_{\mathrm{w}}$ & $\mathrm{N}: \mathrm{C}_{\mathrm{w}}$ & $\mathrm{S}: \mathrm{C}_{\mathrm{w}}$ & $\mathrm{P}: \mathrm{C}_{\mathrm{w}}$ & $\mathrm{DBE}_{\mathrm{w}}$ & $\begin{array}{l}\text { \% } \\
\text { Formulae } \\
\text { with } \\
\text { CHO }\end{array}$ & $\begin{array}{l}\% \\
\text { Formulae } \\
\text { with } \\
\text { CHON }\end{array}$ & $\begin{array}{l}\% \text { Formulae with } \\
\text { CHONP, } \\
\text { CHONS, } \\
\text { CHONSP }\end{array}$ \\
\hline $\begin{array}{l}\text { Yellow } \\
\text { Snow }\end{array}$ & 5113 & 4380 & 85.7 & 1.22 & 0.41 & 0.30 & 0.04 & 0.05 & 9.79 & 17.4 & 23.4 & 42.5 \\
\hline $\begin{array}{l}\text { Supraglacial } \\
\text { Inland }\end{array}$ & 1865 & 1169 & 62.7 & 1.16 & 0.40 & 0.33 & 0.03 & 0.05 & 12.15 & 1.7 & 32.0 & 50.1 \\
\hline $\begin{array}{l}\text { Supraglacial } \\
\text { Margin }\end{array}$ & 2331 & 1980 & 84.9 & 1.68 & 0.27 & 0.27 & 0.01 & 0.03 & 6.21 & 23.3 & 34.7 & 25.0 \\
\hline $\begin{array}{l}\text { Subglacial } \\
\text { May }\end{array}$ & 1737 & 1662 & 95.7 & 1.56 & 0.38 & 0.17 & 0.00 & 0.01 & 6.66 & 55.6 & 26.1 & 11.3 \\
\hline $\begin{array}{l}\text { Subglacial } \\
\text { July-1 }\end{array}$ & 3330 & 3249 & 97.6 & 1.26 & 0.38 & 0.16 & 0.00 & 0.02 & 9.62 & 69.2 & 8.1 & 18.9 \\
\hline $\begin{array}{l}\text { Subglacial } \\
\text { July-2 }\end{array}$ & 3048 & 2800 & 91.9 & 1.24 & 0.38 & 0.21 & 0.00 & 0.02 & 10.08 & 58.9 & 10.8 & 26.2 \\
\hline Tarn & 5958 & 5826 & 97.8 & 1.27 & 0.43 & 0.12 & 0.00 & 0.01 & 10.28 & 65.7 & 12.3 & 17.5 \\
\hline $\begin{array}{l}\text { Suwannee } \\
\text { River }\end{array}$ & 2092 & 2079 & 99.4 & 1.05 & 0.55 & 0.03 & 0.00 & 0.01 & 10.85 & 91.3 & 2.0 & 4.5 \\
\hline
\end{tabular}


DOM compositions (Fig. 2). Although ultra-high resolution mass spectrometry has not been used to date to compare DOM from different glacial sub-environments, this result is not surprising since both bulk DOC concentrations and in situ microbial communities can differ vastly among glacial sub-environments (Bhatia et al., 2006).

Cluster analysis based on the presence/absence of resolved peaks in negative ion mode (Fig. 3) revealed that the samples collected on the inland ice sheet (Yellow Snow, Supraglacial Inland) were distinct from each other as well as from those collected at the ice sheet margin (Subglacial May, Supraglacial Margin, Tarn, Subglacial July-1, 2). Indeed, the Yellow Snow and Supraglacial Inland samples share very few peaks $(<20 \%)$ with any of the samples col- lected at the ice margin (Table 3). The cluster analysis for positive ion mode data (not shown) confirmed that the three samples from the inland ice sheet surface (Yellow Snow, Red Snow, and Supraglacial Inland) were distinct from the ice margin samples (Subglacial May, Supraglacial Margin, Tarn, Subglacial July-1). Differentiation between these sample groups is expected since the Yellow Snow and Red Snow should represent very different, localized regions on the ice sheet surface with unique algal and microbial communities. The lack of similarity between the supraglacial meltwater samples (Supraglacial Inland and Supraglacial Margin, only sharing $13 \%$ and $10 \%$ of their peaks respectively, Table 3) could be attributed to geographical, seasonal and water source differences. For

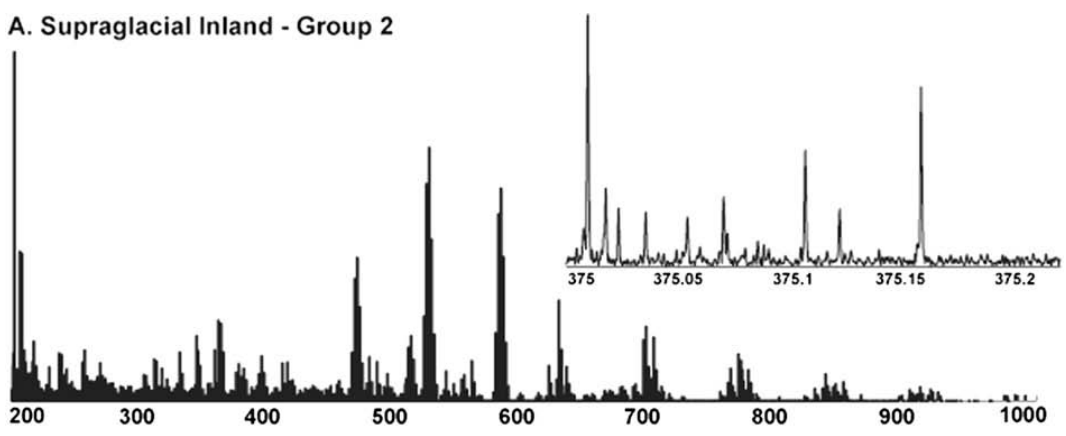

B. Subglacial May - Group 3
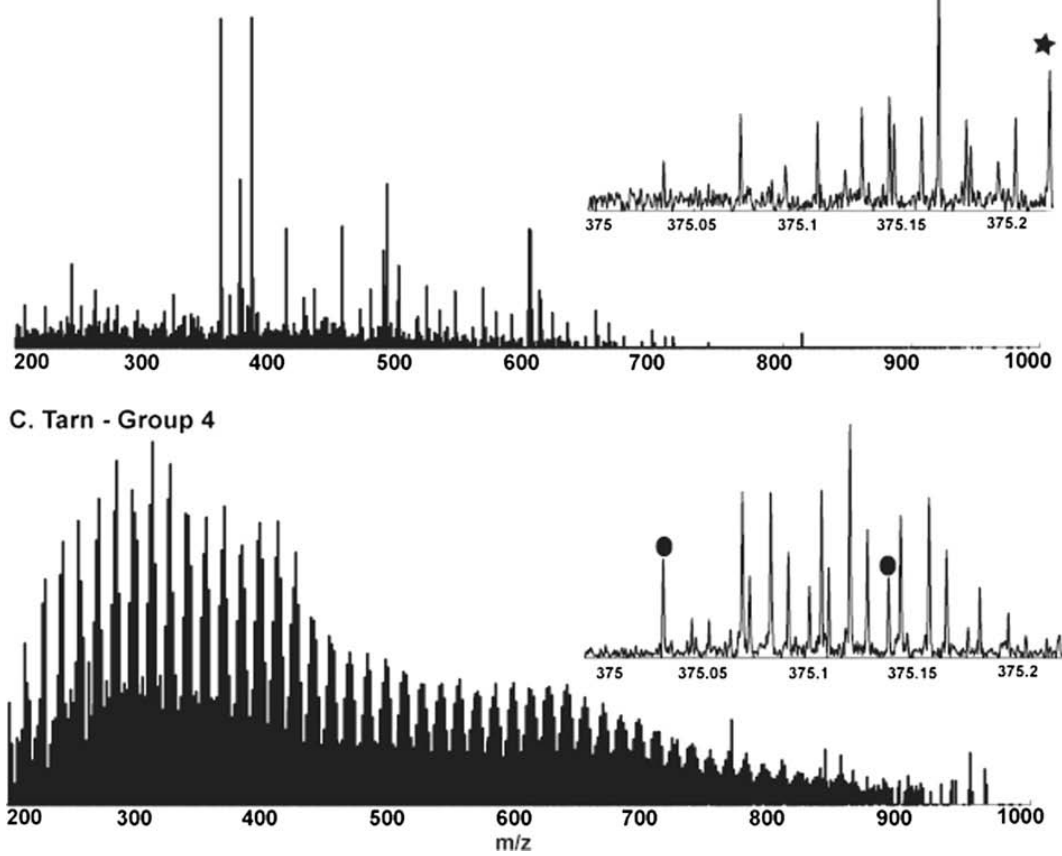

Fig. 2. Negative ion mode blank-corrected, calibrated mass spectra from the groups identified in indicator species and cluster analysis. Group 1: Yellow Snow (not shown); Group 2: Supraglacial Inland; Group 3: N glacier May (Subglacial May and Supraglacial Margin); and Group 4: terrestrial/N glacier July (Tarn and Subglacial July-1,2). The inset shows the region $375.0 \leqslant \mathrm{~m} / \mathrm{z} \leqslant 375.2$ and the indicator $\mathrm{m} / \mathrm{z}$ values for Group 3 (black stars) and Group 4 (black ovals). 
Cluster diagram of negative ion mode presence/absence data

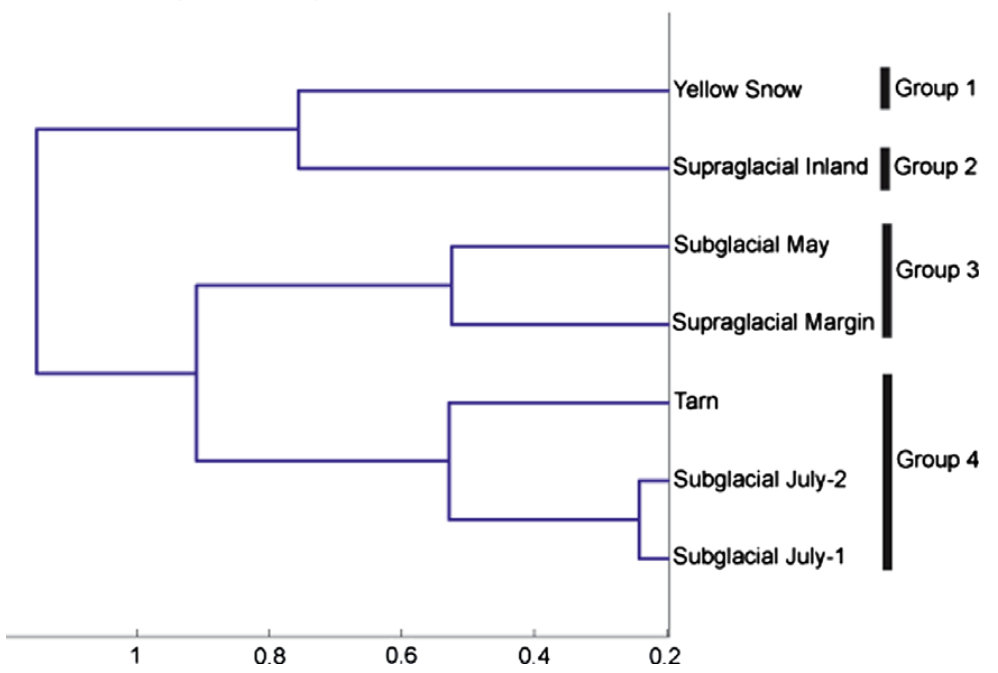

Fig. 3. Cluster diagram of the seven negative ion mode samples, based on Bray-Curtis distance measure and Ward's linkage method.

Table 3

Percentage of negative ion mode peaks shared between the different samples analyzed in this study and Suwannee River.

\begin{tabular}{|c|c|c|c|c|c|c|c|c|}
\hline Sample & $\begin{array}{l}\text { Yellow } \\
\text { Snow }\end{array}$ & $\begin{array}{l}\text { Supraglacial } \\
\text { Inland }\end{array}$ & $\begin{array}{l}\text { Supraglacial } \\
\text { Margin }\end{array}$ & $\begin{array}{l}\text { Subglacial } \\
\text { May }\end{array}$ & $\begin{array}{l}\text { Subglacial } \\
\text { July-1 }\end{array}$ & $\begin{array}{l}\text { Subglacial } \\
\text { July-2 }\end{array}$ & Tarn & $\begin{array}{l}\text { Suwannee } \\
\text { River }\end{array}$ \\
\hline $\begin{array}{l}\% \text { Yellow Snow shared } \\
\text { with }\end{array}$ & 100 & 17 & 16 & 13 & 15 & 15 & 18 & 9 \\
\hline $\begin{array}{l}\% \text { Supraglacial Inland } \\
\text { shared with }\end{array}$ & 46 & 100 & 13 & 7 & 11 & 14 & 9 & 4 \\
\hline $\begin{array}{l}\% \text { Supraglacial Margin } \\
\text { shared with }\end{array}$ & 35 & 11 & 100 & 42 & 39 & 35 & 35 & 11 \\
\hline $\begin{array}{l}\% \text { Subglacial May shared } \\
\text { with }\end{array}$ & 39 & 7 & 56 & 100 & 61 & 56 & 60 & 36 \\
\hline $\begin{array}{l}\% \text { Subglacial July-1 shared } \\
\text { with }\end{array}$ & 23 & 6 & 27 & 32 & 100 & 73 & 79 & 39 \\
\hline $\begin{array}{l}\% \text { Subglacial July-2 shared } \\
\text { with }\end{array}$ & 24 & 9 & 27 & 32 & 79 & 100 & 73 & 39 \\
\hline$\%$ Tarn shared with & 16 & 3 & 14 & 18 & 44 & 37 & 100 & 25 \\
\hline $\begin{array}{l}\% \text { Suwannee River shared } \\
\text { with }\end{array}$ & 22 & 4 & 12 & 29 & 62 & 57 & 70 & 100 \\
\hline
\end{tabular}

example, the Supraglacial Inland sample was collected from a large supraglacial lake composed almost entirely of inland ice melt. In contrast, the Supraglacial Margin sample was collected from a small meltwater pool closer to the ice edge and much earlier in the melt season, and thus is comprised of a mixture of marginal snow and ice melt.

Among the margin-site samples, results from the cluster analyses for positive and negative ion modes indicate that the DOM composition in the subglacial runoff changes during the melt season. Specifically, the negative ion mode cluster analysis illustrates that the ' $\mathrm{N}$ ' glacier May samples (Supraglacial Margin and Subglacial May) were grouped (sharing $42 \%$ and $56 \%$ of their peaks respectively, Table 3 ) as were the Subglacial July-1, 2 and Tarn samples (Subglacial July samples sharing $73-79 \%$ of their peaks with the Tarn sample, Table 3). Interestingly, the Subglacial July samples are quite distinct from the Subglacial May sample even though the two samples were collected from the same location. In addition, there is significant peak overlap between Suwannee River and the Tarn sample $(70 \%)$ and between the Subglacial July samples (57-62\%), but much less between Suwannee River and the Subglacial May sample $(30 \%)$. Thus, although our samples are temporally limited (May and July), we infer that the type of DOM in subglacial discharge changed during the 2008 melt season.

\subsection{Elemental formula assignments and indicator species analysis}

We were able to assign formulae to over $90 \%$ of the resolved peaks in the Suwannee River and the Tarn, Subglacial July-1, 2, and Subglacial May samples. We achieved slightly lower percentages of formulae assigned to the Yellow Snow $(86 \%)$ and Supraglacial Margin $(85 \%)$ samples, with the 
lowest percentage of formulae found for the Supraglacial Inland sample $(63 \%)$. In an effort to increase the percentage of formula assignments in this sample, we made two temporary modifications to CIA. First, we included halogens $(\mathrm{F}, \mathrm{Cl}, \mathrm{Br}$, and I) in our formula assignments; and second, we attempted to account for multiply-charged molecules. Inclusion of halogens did not increase our formula assignment rate appreciably. In contrast, corrections for doubly- and triply-charged molecules produced a marked increase in the Supraglacial Inland formula assignment percentage (up to 98\%), suggesting that a good portion of our $\mathrm{m} / \mathrm{z}$ values represented multiplycharged molecules with multiple de-protonation sites. We discarded these improvements, however, because the modified CIA lowered the formula assignment accuracy when tested with Suwannee River formulae and because multiply-charged isotopomers were rarely available for reliable charge-state determination. Thus, we were forced to retain the original lower formula assignment percentages made to the Supraglacial Inland sample.

Elemental formulae containing only $\mathrm{C}, \mathrm{H}$, and $\mathrm{O}$ dominated the formula assignments for the Tarn and subglacial samples (Subglacial May and Subglacial July-1, 2) (Table 2). Conversely, the supraglacial samples were dominated by formulae containing $\mathrm{C}, \mathrm{H}, \mathrm{O}$, and $\mathrm{N}$ (Supraglacial Margin), or $\mathrm{C}, \mathrm{H}, \mathrm{O}, \mathrm{N}$, and S/P (Yellow Snow, Supraglacial Inland) (Table 2). We should note that this result differs from analysis of other supraglacial organic material in ice cores collected from Russia where formulae containing C, $\mathrm{H}$, and $\mathrm{O}$ were the most abundant (Grannas et al., 2006). However, the snow and meltwater samples analyzed in this study (i.e., collected from marginal areas where there is snow melt and water in the residual snowpack) are quite different from bulk ice core material (i.e., collected from inland areas where ice is formed in the dry snow zone), so it is not surprising that we resolved different compounds.

For comparison with other DOM compositional studies, we calculated the magnitude-averaged bulk elemental ratios and double-bond equivalency (DBE) for all samples (Table 2) (Koch et al., 2008; Sleighter and Hatcher, 2008). Molecular $\mathrm{H}: \mathrm{C}$ and $\mathrm{O}: \mathrm{C}$ ratios have been reported previously to range broadly from 0.3 to 1.8 and 0 to 0.8 , respectively (Koch et al., 2008; Sleighter and Hatcher, 2008; Stenson et al., 2003). The elemental ratios of all of our samples fall within this range (Table 2), with Suwannee River being the most aromatic $(\mathrm{H}: \mathrm{C}=1.05)$, and the Subglacial May and Supraglacial Margin samples being the most aliphatic (H:C $=1.68$ and 1.56, respectively). The low DBE of the Supraglacial Margin and Subglacial May samples also imply that DOM in these samples is relatively aliphatic. The DBE was the highest in the Supraglacial Inland sample. This fact, combined with the relatively lower $\mathrm{H}: \mathrm{C}$ ratio (1.16) and relatively higher $\mathrm{N}: \mathrm{C}$ ratio $(0.33)$ of this sample (Table 2), suggest that molecules within this sample may contain condensed nitrogen functionalities (i.e., aromatic nitrogen or nitro groups). Finally, the supraglacial samples (Yellow Snow, Supraglacial Inland, Supraglacial Margin) generally had relatively high $\mathrm{N}: \mathrm{C}$ ratios $(0.30,0.33,0.27$, respectively, Table 2), suggesting that nitrogen-containing molecules could be major contributors to DOM in these samples (Reemtsma et al., 2008).
Van Krevelen diagrams were generated for all Greenland samples and Suwannee River in order to compare DOM composition across our samples (representative sample plots in Fig. 4). Van Krevelen diagrams illustrate the $\mathrm{O}: \mathrm{C}$ molar ratio and the $\mathrm{H}: \mathrm{C}$ molar ratio of each elemental formula on the $x$ - and $y$-axes, respectively. Generally, major biogeochemical compound classes (such as condensed hydrocarbons, lipids, proteins, lignins, and carbohydrates) have characteristic $\mathrm{H}: \mathrm{C}$ and/or O:C molar ratios, and thus should occupy specific regions of the plot (Kim et al., 2003a; Wu et al., 2004; Kujawinski and Behn, 2006). The percentages of negative ion mode formula assignments located in the different regions of the van Krevelen diagram are presented in Table 4. However, we should note that van Krevelen diagrams should be interpreted with caution as inconsistent definitions of particular compound classes across the literature (e.g., lipid), and variable O:C or $\mathrm{H}: \mathrm{C}$ ratios within particular compound classes (e.g., proteins) may lead to exclusion of elemental formulae from the prescribed compound class regions (Kujawinski and Behn, 2006). Nonetheless, at present, they remain the best way to graphically depict elemental formula assignments for mass spectra comprised of thousands of peaks.

The van Krevelen plot of the negative ion mode Suwannee River sample (not shown) is consistent with previous work (Stenson et al., 2003). Over $99 \%$ of formulae were assigned and most occur in the region associated with ligninderived materials (Stenson et al., 2003). Very few formulae are present in the regions associated with proteins and lipids (Table 4). Because of these results and the fact that Suwannee River is well-cited as a terrestrial DOM endmember (e.g. McKnight et al., 2001; Stenson et al., 2003), we label the region encompassing the majority of its elemental formula assignments as "terrestrial" (shown in Figs. 4 and 5), and use this information to aid our analyses of our negative ion mode spectra.

The van Krevelen diagrams may explain the observed cluster groupings in Fig. 3. In negative ion mode, the separation between the samples collected on the ice sheet surface and those collected at the margin may be the result of the Yellow Snow and Supraglacial Inland samples having a greater representation in the condensed hydrocarbon region and a lower proportion in the lignin region (Table 4). The grouping of the Subglacial May and Supraglacial Margin samples may be due to greater proportions of protein-like and lipid-like material in these samples compared to the remainder of the dataset (Table 4). The grouping of the Tarn and Subglacial July samples results from a commonality in every region of the van Krevelen plot, particularly in the terrestrial Suwannee River and lignin regions (Table 4).

Apart from these general trends, each sample also has some noteworthy features on the van Krevelen diagram. In addition to a large protein-like component, the Supraglacial Margin sample also contains more formulae in the lipid and the condensed hydrocarbon regions than the Subglacial May sample (Table 4). Even though both the Supraglacial Margin and Subglacial May samples contain lignin-like molecules, the Subglacial May sample has a larger proportion of formulae in the "terrestrial" Suwannee 


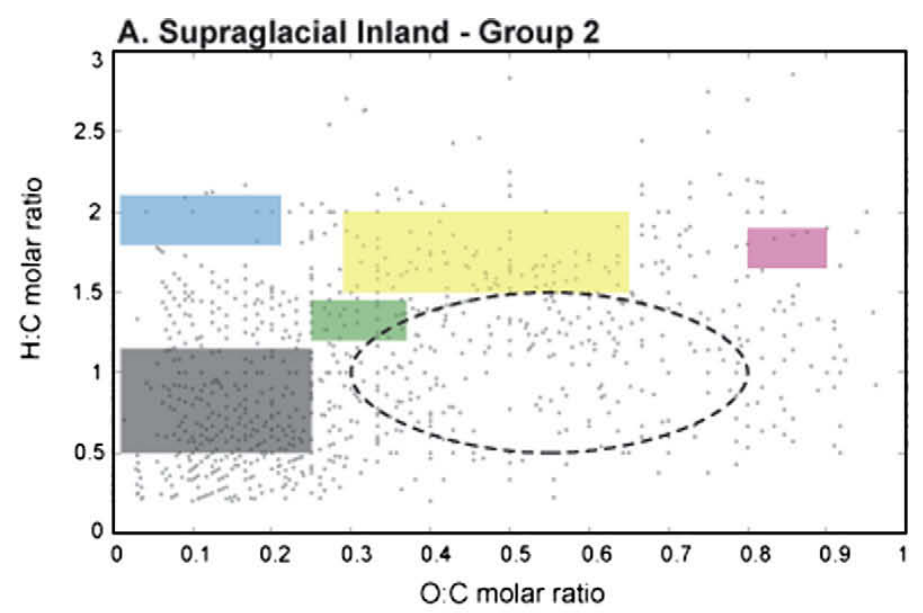

B. Subglacial May - Group 3

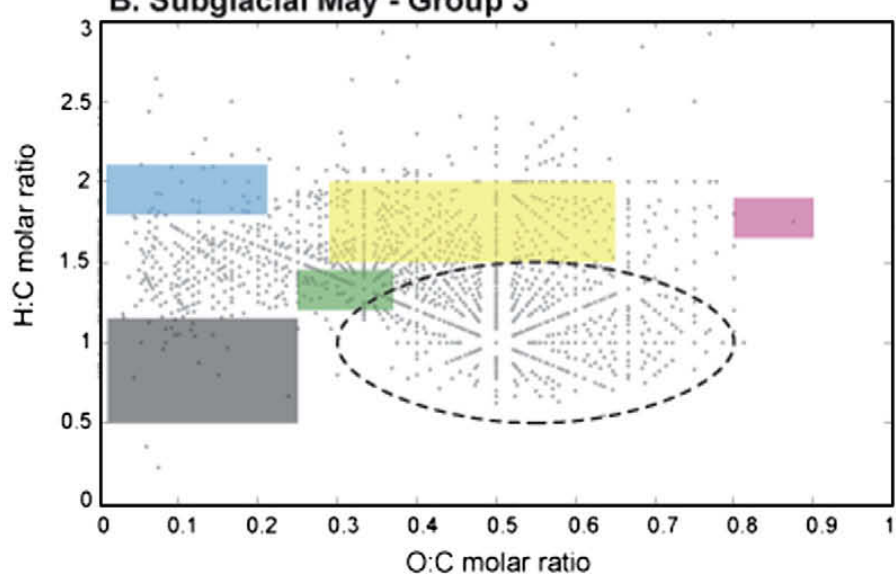

C. Tarn - Group 4

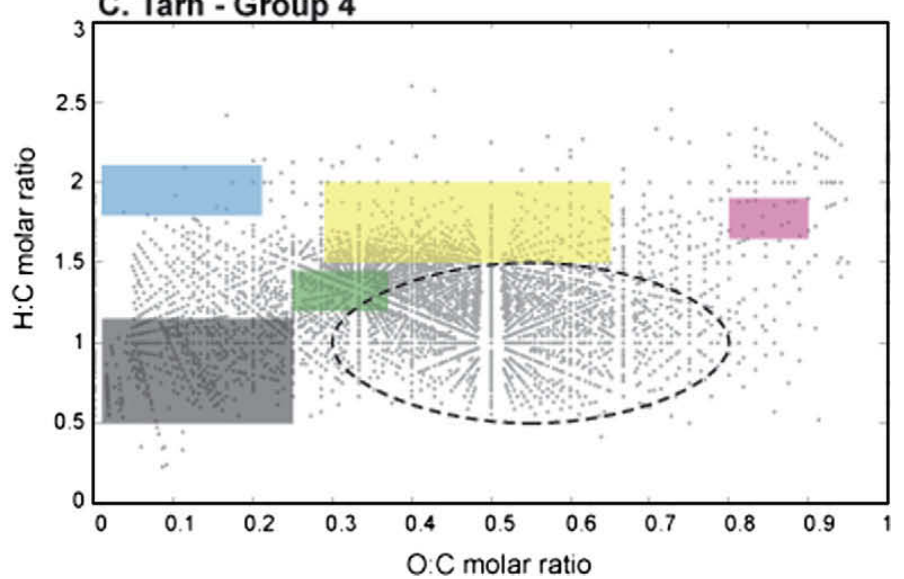

Fig. 4. Van Krevelen diagrams of all formulae assigned (grey dots) to negative ion mode peaks detected within the Supraglacial Inland (A), Subglacial May (B), and Tarn (C) samples. The colored boxes represent elemental compositions for some major compound classes, as approximated from Kim et al. (2003) and Hedges (1990). The grey box represents condensed hydrocarbons, the blue box represents lipids, the green box represents lignin, the yellow box represents proteins, and the pink box represents carbohydrates. The black oval represents elemental formula assignments made for a sample of Suwannee River Fulvic Acid. (For interpretation of the references to colour in this figure legend, the reader is referred to the web version of this article.) 
Table 4

Percentage of negative ion mode formula assignments located in different regions of the van Krevelen diagram. Group numbers refer to groups determined by indicator species analysis (see text for details).

\begin{tabular}{|c|c|c|c|c|c|c|}
\hline Sample & Condensed hydrocarbons & Lipids & Lignin & Protein & Carbohydrate & Terrestrial \\
\hline Yellow Snow (Group 1) & 12.6 & 1.1 & 3.0 & 12.7 & 0.6 & 29.2 \\
\hline Supraglacial Inland (Group 2) & 16.0 & 0.5 & 2.4 & 9.2 & 0.6 & 23.5 \\
\hline Supraglacial Margin (Group 3) & 6.8 & 4.7 & 3.6 & 27.0 & 0.3 & 14.3 \\
\hline Subglacial May (Group 3) & 1.1 & 1.5 & 5.5 & 25.5 & 0.1 & 39.2 \\
\hline Subglacial July-1 (Group 4) & 6.9 & 0.9 & 10.2 & 10.4 & 0.1 & 55.6 \\
\hline Subglacial July-2 (Group 4) & 7.8 & 1.1 & 8.5 & 8.4 & 0.0 & 55.8 \\
\hline Tarn (Group 4) & 9.8 & 0.1 & 7.5 & 13.3 & 0.3 & 59.3 \\
\hline Suwannee River & 2.0 & 0.0 & 4.5 & 1.9 & 0.0 & 85.6 \\
\hline
\end{tabular}

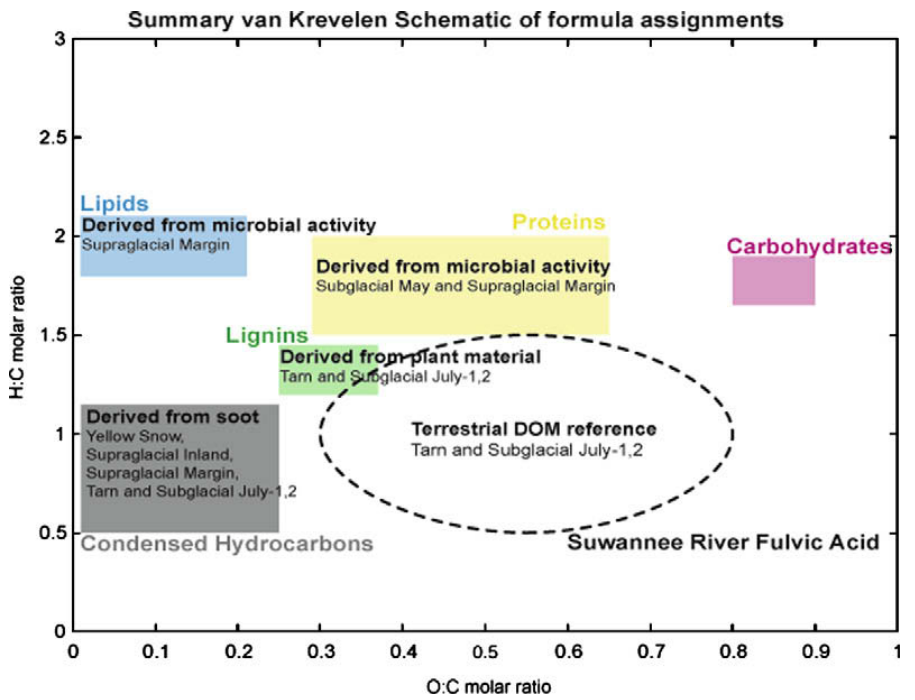

Fig. 5. Van Krevelen diagram summarizing the formula assignments for the negative ion mode samples. The samples/groups containing a high proportion of peaks in the different compound classes are named.

River region (Table 4). The Tarn and Subglacial July samples all contain a larger proportion of formulae in the condensed hydrocarbon and protein regions than the Suwannee River sample (Table 4). The results of our analyses of the van Krevelen plots for each of the samples are summarized in Fig. 5.

Indicator species analysis revealed that a higher content of biologically-derived elemental formulae is responsible for the differentiation of the Subglacial May and Supraglacial Margin samples (Group 3) from the Tarn and Subglacial July samples (Group 4). Indicator $m / z$ values for the Group 3 samples are dominated by high $\mathrm{H}: \mathrm{C}$ compounds occupying the protein region of the van Krevelen diagram (Fig. 6A). Conversely, the indicator $\mathrm{m} / \mathrm{z}$ values for the Group 4 samples are dominated by low $\mathrm{H}: \mathrm{C}$ compounds found in the terrestrial Suwannee River region. There is a significant terrestrial component within all the ice margin samples, as evidenced by the presence of indicator $\mathrm{m} / \mathrm{z}$ values common to Groups 3 and 4 (yellow dots, Fig. 6B) in this region. This component is absent in the samples collected on the inland ice sheet surface (Yellow Snow and Supraglacial Inland, Groups 1 and 2).

\subsection{Potential sources of observed peaks}

\subsubsection{Microbially-derived material (lipid-like and protein- like signatures)}

Similar to previous fluorescence studies (Lafreniere and Sharp, 2004; Barker et al., 2006), the distinct microbial character of the Supraglacial Margin sample (reflected by its high proportion of protein-like formulae) is likely derived from photosynthetic algae and bacteria communities widely observed to be present in supraglacial environments (Carpenter et al., 2000; Grannas et al., 2004; Foreman et al., 2007). The presence of lipid-like material in the Supraglacial Margin sample also correlates well with previous work identifying biologically-derived lipids in organic matter from snow collected at Summit atop the Greenland ice sheet (Grannas et al., 2004; Grannas et al., 2006).

Early season (spring) subglacial waters have also been observed to have a microbial fluorescence signature (Lafreniere and Sharp, 2004; Barker et al., 2006), despite the fact that terrestrial carbon from overridden soils and vegetation is also present at the glacier base (Sharp et al., 1999). The larger proportion of protein-like formulae in 

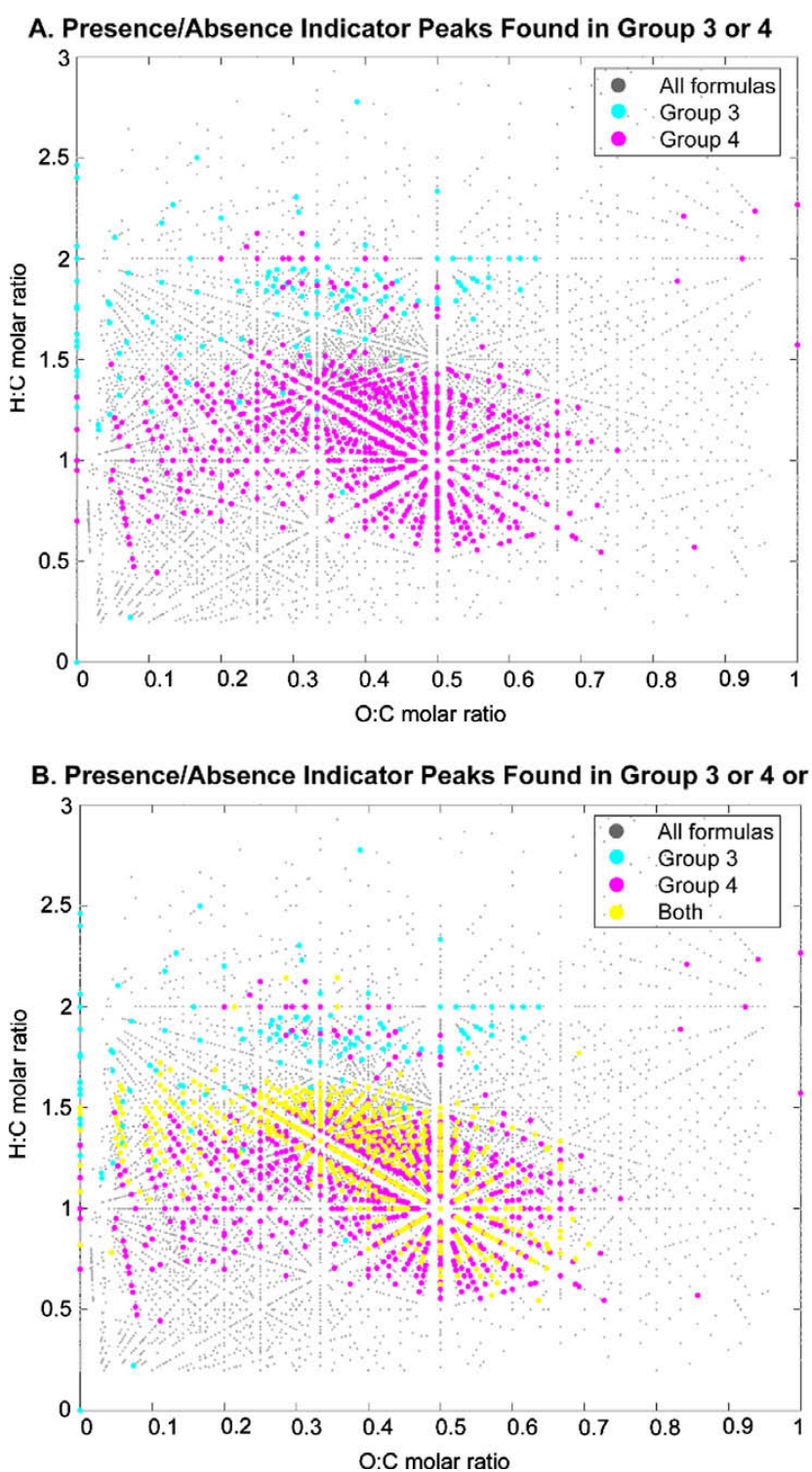

Fig. 6. Van Krevelen negative ion mode diagrams with indicator peaks determined by Indicator Species Analysis. In (A), indicator peaks exclusive to either Group 3 (N glacier May (Subglacial May and Supraglacial Margin)) or Group 4 (terrestrial/N glacier July (Tarn and Subglacial July-1, 2)) are shown; in (B), peaks from (A) are shown as well as indicator peaks found in both Groups 3 and 4.

the early season subglacial waters (Subglacial May) may reflect in situ subglacial microbial metabolism of some component of the subglacial organic carbon stores during over winter storage (Tranter et al., 2005). The May subglacial water likely drains a broad distributed hydrological network along the ice-bed interface, and consequently experiences prolonged storage at the bed where active subglacial microbial communities are thought to be present (Tranter et al., 2005). Although no study has documented the presence of subglacial communities beneath the Greenland ice sheet specifically, a mounting body of literature indicates that large, active microbial communities are present beneath glaciers in diverse regions on varying lithologies (the Swiss Alps, southern New Zealand Alps, Alaska, Svalbard, Antarctica, and the Canadian high Arctic) (Sharp et al., 1999; Skidmore et al., 2000; Lanoil et al., 2009; Mikucki et al., 2009). Furthermore, studies show that the abundances of subglacial communities (as high as $1.8 \times 10^{9}$ cells $\mathrm{g}^{-1}$ ) are similar to the highest microbial abundances in permafrost $\left(10^{7}-10^{9}\right.$ cells $\mathrm{g}^{-1}$ ) (Sharp et al., 1999). Documented subglacial communities include heterotrophic bacteria (e.g., aerobic respires, nitrate- and sulfate- 
reducers) as well as autotrophic bacteria (e.g., methanogens) (Skidmore et al., 2000; Foght et al., 2004; Cheng and Foght, 2007). The existence of numerically-abundant, enduring biological communities implies that any microbially-mediated biogeochemical activities occur on a continuous temporal basis. The diverse DOM composition in the Subglacial May sample is consistent with the idea of high subglacial microbial activity due in particular to its significant protein and terrestrial components (Table 4).

\subsubsection{Terrestrial-derived material (lignins and Suwannee River-like components)}

Lignins and formulae located in the "terrestrial" region of our van Krevelen plots are likely derived from previously overridden soils and vegetation (subglacial samples) or surrounding terrestrial soils and vegetation (Tarn). The large component of terrestrially-derived DOM in the Tarn sample (overlap between Suwannee River and the Tarn sample is $70 \%$ ), is likely derived from its location in the developed soils and vegetation at our study site. In contrast, the subglacial samples contain terrestrially-derived DOM, present in both May and July, that is most likely derived from previously overridden soils and vegetation during glacial advance. The lack of lignin material in the samples collected on the inland ice sheet surface (Yellow Snow, Supraglacial Inland) suggests that organic matter from these environments is not influenced significantly by non-charred terrestrial inputs. This is in contrast to Grannas et al. (2004) who noted the presence of vascular plant tissue (i.e., lignin) in snow collected from Summit, Greenland.

\subsubsection{Condensed hydrocarbons}

Condensed hydrocarbons are generally compounds with a deficiency in both oxygen and hydrogen and often contain aromatic ring structures. Previous studies have illustrated that these compounds originate from black carbon-like molecules (Kim et al., 2004), and could be derived from atmospheric deposition of soot particles (Slater et al., 2002). Evidence of these compound types is present in all ice sheet surface samples (Yellow Snow, Supraglacial Inland, Supraglacial Margin) and the late/summer discharge samples (Subglacial July-1, 2). On the ice sheet surface, this material likely originates from atmospheric deposition of combustion products. We do not anticipate a novel source of condensed hydrocarbons in the subglacial environment. Rather, the presence of condensed hydrocarbons in late season subglacial waters (Subglacial July-1,2) may reflect either (1) the increased contribution of supraglacial meltwater to the subglacial outflow at the peak of the summer melt season, or (2) an increased flux of condensed hydrocarbons from the ice sheet surface after the snow cover has melted. Support for this second hypothesis may be provided by Clarke and Noone (1985), who found that soot may be enriched in Arctic snowmelt compared to the snowpack.

\subsection{Implications for understanding subglacial flow regimes}

The fact that the late season subglacial waters still possess an overwhelming terrestrial signature may reflect the ability of the summer hydrological flow regime to mobilize subglacial organic carbon stores. As the melt season progresses on the Greenland ice sheet, meltwater from seasonal snow and ice collects in streams and lakes on the ice sheet surface. The majority of this surface meltwater is thought to descend to the bed via crevasses and moulins at the peak of the summer melt season (Das et al., 2008; Krawczynski et al., 2009). Thus, the late season subglacial waters are primarily comprised of supraglacial inflow passing rapidly through the subglacial environment. Over the course of a melt season, the ice sheet subglacial drainage system is predicted to evolve from a distributed to a more channelized network facilitating rapid water flow to the glacier front, similar to what has been observed in alpine glacier systems (Nienow et al., 1998). The faster flow rates characteristic of this channelized system do not permit extensive water-sediment interaction, thus minimizing the impact of in situ microbial metabolism (Tranter et al., 2005). Additionally, the larger volumes of water passing through the subglacial system may facilitate turbulent incidental contact that allows the meltwaters to mobilize terrestrial sources of DOC at the glacier base (i.e., previously overridden soil and vegetation). Previous work in alpine catchments has illustrated that suspended sediment concentrations increase throughout a melt season as sediment sources are accessed by an extending and integrating subglacial drainage network (Clifford et al., 1995; Richards et al., 1996). This reasoning is also consistent with previous fluorescence spectroscopy work by Barker et al. (2006) at a polythermal Canadian high Arctic glacier, which showed that the late season subglacial meltwaters bear a terrestrially-derived signature. The change in subglacial flow rate may explain why condensed hydrocarbons are not present in the early season subglacial waters. Increased residence times of these waters at the glacier bed throughout the preceding winter would permit non-polar hydrocarbon-like, soot-derived compounds to adsorb quantitatively to organic particles in the subglacial environment (Kramer et al., 2004) and thus to be removed from discharge waters. At the peak of the summer melt season, the higher meltwater flow rates and potentially elevated hydrocarbon concentrations would preclude quantitative removal by adsorption, allowing the subglacial waters to retain these compounds in the late season subglacial runoff.

\subsection{Implications for understanding glacial organic matter cycling}

The microbial signatures of the subglacial discharge samples analyzed in our study support the suggestion that glacial systems supply labile material to downstream marine and terrestrial environments (Lafreniere and Sharp, 2004; Barker et al., 2006; Hood et al., 2009) extending these results to an ice sheet environment for the first time. This hypothesis follows earlier discoveries of abundant, active microbial communities associated with supraglacial, subglacial, and proglacial environments (Sharp et al., 1999; Anesio et al., 2009; Bhatia et al., 2006). It has been substantiated by direct investigations of glacially-derived DOM, including fluorescence spectrometry (Lafreniere and Sharp, 2004; Barker et al., 2006), compound specific analyses (i.e. 
lignin phenols) (Hood et al., 2009), and bulk organic carbon characterizations ( $\mathrm{C}: \mathrm{N}$ ratios, $\delta^{13} \mathrm{C}$ values) (Hood and Scott, 2008; Hood et al., 2009). Most recently, Hood et al. (2009) demonstrated that the bioavailability of glacial organic carbon is indirectly correlated with age, so that DOM from glaciated catchments is labile despite having ancient $\Delta^{14} \mathrm{C}$ ages. Thus, meltwater streams and rivers draining glaciated areas may potentially provide a significant, previously overlooked source of labile reduced carbon to downstream ecosystems (Barker et al., 2006; Hood et al., 2009). Our study corroborates these findings through a comprehensive molecular-level description of glacially-derived DOM in meltwater runoff from the Greenland ice sheet and offers a novel line of evidence that glacial DOM has a microbial source.

\section{CONCLUSIONS}

Previous studies illustrate that the majority of supraglacial DOM likely originates from autochthonous microbial processes, whereas subglacial DOM contains both allochthonous carbon derived from previously overridden soils and vegetation, and autochthonous carbon derived from in situ microbial metabolism. Our findings support these provenances. Generally the supraglacial and early season subglacial discharge had a higher proportion of protein-like and lipid-like elemental formulae, whereas the tarn and late season subglacial water DOM had a higher proportion of lignin and terrestrial Suwannee River-like materials. However, evolving subglacial flow regimes also likely exert a heavy influence on the type of DOM present in the subglacial outflow at different times of the year. In this study, this influence is reflected in a smaller terrestrial component in the early season subglacial waters, and the detection of condensed hydrocarbon-like material in late season subglacial waters. Based on the samples analyzed, the DOM composition of subglacial outflow shifts from a terrestrial to microbial signature over winter storage and then back to a terrestrial signature through a melt season. We propose that this shift is dependent on the degree of subglacial microbial metabolism that has occurred. However, additional samples and measurements constraining the subglacial flow regime and resident microbial communities are required to fully test the validity of this conjecture.

This study represents the first molecular-level analyses of subglacial organic carbon stores, and as such, has illustrated that ultra-high resolution mass spectrometry can provide unprecedented compositional information regarding the interplay among different glacial carbon pools. In addition to these qualitative results, further work with both bulk and compound-specific measurements will be required to confirm that specific compound classes (e.g., proteins, lipids) are present and to constrain the temporal provenances of these pools. Nevertheless, our results suggest that a much more complex and reactive carbon system is associated with glacial environments than previously thought and merit further investigation, given the extent and frequency of glaciation events through Earth's history.

\section{ACKNOWLEDGEMENTS}

This research was supported by: the National Science Foundation (CAREER-OCE-0529101 (E.B.K.), ARC-0520077 (S.B.D.)), National Atmospheric and Space Administration (S.B.D.), the WHOI Clark Arctic Research Initiative (E.B.K., S.B.D., M.A.C.), the WHOI Ocean Ventures Fund (M.P.B.), and the National and Science Engineering Research Council of Canada (M.P.B.). We acknowledge M. Kido Soule for assistance with data collection and the funding sources of the WHOI FT-MS Users' facility (National Science Foundation OCE-0619608 and the Gordon and Betty Moore Foundation). We are grateful to I. Joughin, M. Behn, R. Harris, B. Gready, P. Henderson, A. Criscitiello, and M. Evans for their assistance in the field, to P. Henderson for conducting the carbon/nitrogen analyses, and to G. Wolken for his assistance in constructing maps of our field site. We also thank three anonymous reviewers whose comments improved the manuscript.

\section{APPENDIX A. SUPPLEMENTARY DATA}

Supplementary data associated with this article can be found, in the online version, at doi:10.1016/j.gca.2010.03. 035 .

\section{REFERENCES}

Anesio A. M., Hodson A. J., Fritz A., Psenner R. and Sattler B. (2009) High microbial activity on glaciers: importance to the global carbon cycle. Global Change Biol. 15, 955-960.

Azam F. (1998) Microbial control of oceanic carbon flux: the plot thickens. Science 280, 694-696.

Bamber J. L., Layberry R. L. and Gogineni S. (2001) A new ice thickness and bed data set for the Greenland ice sheet 1 . Measurement, data reduction, and errors. J. Geophys. Res. D: Atmos. 106, 33773-33780.

Barker J. D., Sharp M. J., Fitzsimons S. J. and Turner R. J. (2006) Abundance and dynamics of dissolved organic carbon in glacier systems. Arct. Antarct. Alp. Res. 38, 163-172.

Berner R. A., Lasaga A. C. and Garrels R. M. (1983) The carbonate-silicate geochemical cycle and its effect on atmospheric carbon-dioxide over the past 100 million years. Am. J. Sci. 283, 641-683.

Bhatia M., Sharp M. and Foght J. (2006) Distinct bacterial communities exist beneath a high arctic polythermal glacier. Appl. Environ. Microbiol. 72, 5838-5845.

Bingham R. G., Nienow P. W., Sharp M. J. and Boon S. (2005) Subglacial drainage processes at a high Arctic polythermal valley glacier. J. Glaciol. 51, 15-24.

Brown G. H. (2002) Glacier meltwater hydrochemistry. Appl. Geochem. 17, 855-883.

Carpenter E., Lin S. and Capone D. (2000) Bacterial activity in South Pole snow. Appl. Environ. Microbiol. 66, 4514-4517.

Cheng S. M. and Foght J. M. (2007) Cultivation-independent and dependent characterization of bacteria resident beneath John Evans Glacier. FEMS Microbiol. Ecol. 59, 318-330.

Chillrud S. N., Pedrozo F. L., Temporetti P. F., Planas H. F. and Froelich P. N. (1994) Chemical weathering of phosphate and germanium in glacial meltwaters: effects of subglacial pyrite oxidation. Limnol. Oceanogr. 39, 1130-1140.

Clarke A. D. and Noone K. J. (1985) Soot in the Arctic snowpack: a cause for perturbations in radiative transfer. Atmos. Environ. 19, 2045-2053. 
Clifford N. J., Richards K. S., Brown R. A. and Lane S. N. (1995) Scales of variation of suspended sediment concentration and turbidity in a glacial meltwater stream. Geogr. Ann. Ser. APhys. Geogr. 77A, 45-65.

Das S. B., Joughin I., Behn M. D., Howat I. M., King M. A., Lizarralde D. and Bhatia M. P. (2008) Fracture propagation to the base of the Greenland Ice Sheet during supraglacial lake drainage. Science 320, 778-781.

Dittmar T., Koch B., Hertkorn N. and Kattner G. (2008) A simple and efficient method for the solid-phase extraction of dissolved organic matter (SPE-DOM) from seawater. Limnol. Oceanogr. Methods 6, 230-235.

Eglinton T. I. and Repeta D. J. (2003) Organic matter in the contemporary ocean. In Treatise on Geochemistry: Marine Organic Geochemistry, vol. 6 (ed. H. Elderfield). Elsevier, pp. 145-180.

Foght J., Aislabie J., Turner S., Brown C. E., Ryburn J., Saul D. J. and Lawson W. (2004) Culturable bacteria in subglacial sediments and ice from two Southern Hemisphere glaciers. Microbiol. Ecol. 47, 329-340.

Foreman C. M., Sattler B., Mikucki J. A., Porazinska D. L. and Priscu J. C. (2007) Metabolic activity and diversity of cryoconites in the Taylor Valley, Antarctica. J. Geophys. Res. Biogeosci. 112, 11.

Grannas A. M., Hockaday W. C., Hatcher P. G., Thompson L. G. and Mosley-Thompson E. (2006) New revelations on the nature of organic matter in ice cores. J. Geophys. Res. D: Atmos. 111, D04304.

Grannas A. M., Shepson P. B. and Filley T. R. (2004) Photochemistry and nature of organic matter in Arctic and Antarctic snow. Global Biogeochem. Cycles 18, GB1006.

Hedges J. I. (1990) Compositional indicators of organic acid sources and reactions in natural environments. In Organic Acids in Aquatic Ecosystems (eds. E. M. Perdue and E. T. Gjessing). John Wiley \& Sons, Ltd..

Hedges J. I., Eglinton G., Hatcher P. G., Kirchman D. L., Arnosti C., Derenne S., Evershed R. P., Kogel-Knabner I., de Leeuw J. W., Littke R., Michaelis W. and Rullkotter J. (2000) The molecularly-uncharacterized component of nonliving organic matter in natural environments. Org. Geochem. 31, 945-958.

Hood E., Fellman J., Spencer R. G. M., Hernes P. J., Edwards R., D'Amore D. and Scott D. (2009) Glaciers as a source of ancient and labile organic matter to the marine environment. Nature 462, 1044-1047.

Hood E. and Scott D. (2008) Riverine organic matter and nutrients in southeast Alaska affected by glacial coverage. Nat. Geosci. 1, 583-587.

Kim S., Kaplan L. A., Benner R. and Hatcher P. G. (2004) Hydrogen-deficient molecules in natural riverine water samples - evidence for the existence of black carbon in DOM. Mar. Chem. 92, 225-234.

Kim S., Kramer R. W. and Hatcher P. G. (2003a) Graphical method for analysis of ultrahigh-resolution broadband mass spectra of natural organic matter, the Van Krevelen diagram. Anal. Chem. 75, 5336-5344.

Kim S., Rodgers R. P. and Marshall A. G. (2006) Truly "exact" mass: elemental composition can be determined uniquely from molecular mass measurement at similar to $0.1 \mathrm{mDa}$ accuracy for molecules up to similar to $500 \mathrm{Da}$. Int. J. Mass Spectrom. 251, 260-265

Kim S., Simpson A. J., Kujawinski E. B., Freitas M. A. and Hatcher P. G. (2003b) High resolution electrospray ionization mass spectrometry and 2D solution NMR for the analysis of DOM extracted by C-18 solid phase disk. Org. Geochem. 34, 1325-1335.
Koch B. P., Ludwichowski K. U., Kattner G., Dittmar T. and Witt M. (2008) Advanced characterization of marine dissolved organic matter by combining reversed-phase liquid chromatography and FT-ICR-MS. Mar. Chem. 111, 233-241.

Koch B. P., Witt M. R., Engbrodt R., Dittmar T. and Kattner G. (2005) Molecular formulae of marine and terrigenous dissolved organic matter detected by electrospray ionization Fourier transform ion cyclotron resonance mass spectrometry. Geochim. Cosmochim. Acta 69, 3299-3308.

Kramer R. W., Kujawinski E. B. and Hatcher P. G. (2004) Identification of black carbon derived structures in a volcanic ash soil humic acid by Fourier transform ion cyclotron resonance mass spectrometry. Environ. Sci. Technol. 38, $3387-$ 3395.

Krawczynski M. J., Behn M. D., Das S. B. and Joughin I. (2009) Constraints on the lake volume required for hydro-fracture through ice sheets. Geophys. Res. Lett. 36, L10501.

Kujawinski E. B. (2002) Electrospray ionization Fourier transform ion cyclotron resonance mass spectrometry (ESI FT-ICR MS): characterization of complex environmental mixtures. Environ. Forensics 3, 207-216.

Kujawinski E. B. and Behn M. D. (2006) Automated analysis of electrospray ionization Fourier transform ion cyclotron resonance mass spectra of natural organic matter. Anal. Chem. $\mathbf{7 8}$, 4363-4373.

Kujawinski E. B., Longnecker K., Blough N. V., Vecchio R. D., Finlay L., Kitner J. B. and Giovannoni S. J. (2009) Identification of possible source markers in marine dissolved organic matter using ultrahigh resolution mass spectrometry. Geochim. Cosmochim. Acta 73, 4384-4399.

Lafreniere M. J. and Sharp M. J. (2004) The concentration and fluorescence of dissolved organic carbon (DOC) in glacial and nonglacial catchments: interpreting hydrological flow routing and DOC sources. Arct. Antarct. Alp. Res. 36, $156-165$

Lanoil B., Skidmore M., Priscu J. C., Han S., Foo W., Vogel S. W., Tulaczyk S. and Engelhardt H. (2009) Bacteria beneath the West Antarctic Ice Sheet. Environ. Microbiol. 11, 609-615.

Layberry R. L. and Bamber J. L. (2001) A new ice thickness and bed data set for the Greenland ice sheet 2. Relationship between dynamics and basal topography. J. Geophys. Res. D: Atmos. 106, 33781-33788.

Lyons W. B., Welch K. A. and Doggett J. K. (2007) Organic carbon in Antarctic snow. Geophys. Res. Lett. 34

Mantini D., Petrucci F., Pieragostino D., Del Boccio P., Di Nicola M., Di Ilio C., Federici G., Sacchetta P., Comani S. and Urbani A. (2007) LIMPIC: a computational method for the separation of protein MALDI-TOF-MS signals from noise. BMC Bioinf. 8

Marshall A. G. and Rodgers R. P. (2008) Petroleomics: chemistry of the underworld. Proc. Nat. Acad. Sci. USA 105, 18090 18095 .

McCune B. and Grace J. 2002. Analysis of Ecological Communities. MjM Software Design, Gleneden Beach, Oregon.

McKnight D. M., Andrews E. D., Spaulding S. A. and Aiken G. R. (1994) Aquatic fulvic acids in algal rich antarctic ponds. Limnol. Oceanogr. 39, 1972-1979.

McKnight D. M., Boyer E. W., Westerhoff P. K., Doran P. T., Kulbe T. and Andersen D. T. (2001) Spectrofluorometric characterization of dissolved organic matter for indication of precursor organic material and aromaticity. Limnol. Oceanogr. 46, 38-48.

Mikucki J. A., Pearson A., Johnston D. T., Turchyn A. V., Farquhar J., Schrag D. P., Anbar A. D., Priscu J. C. and Lee P. A. (2009) A contemporary microbially maintained subglacial ferrous "ocean". Science 324, 397-400. 
Nienow P., Sharp M. and Willis I. C. (1998) Seasonal changes in the morphology of the subglacial drainage system, Haut Glacier d'Arolla, Switzerland. Earth Surf. Process. Landf. 23, 825-843.

Raiswell R. (1984) Chemical models of solute acquisition in glacial meltwaters. J. Glaciol. 30, 49-57.

Reemtsma T., These A., Linscheid M., Leenheer J. and Spitzy A. (2008) Molecular and structural characterization of dissolved organic matter from the deep ocean by FTICR-MS, including hydrophilic nitrogenous organic molecules. Environ. Sci. Technol. 42, 1430-1437.

Richards K., Sharp M., Arnold N., Gurnell A., Clark M., Tranter M., Nienow P., Brown G., Willis I. and Lawson W. (1996) An integrated approach to modelling hydrology and water quality in glacierized catchments. Hydrol. Processes 10, 479-508.

Sharp M., Parkes J., Cragg B., Fairchild I. J., Lamb H. and Tranter M. (1999) Widespread bacterial populations at glacier beds and their relationship to rock weathering and carbon cycling. Geology 27, 107-110.

Skidmore M., Anderson S. P., Sharp M., Foght J. and Lanoil B. D. (2005) Comparison of microbial community compositions of two subglacial environments reveals a possible role for microbes in chemical weathering processes. Appl. Environ. Microbiol. 71, 6986-6997.

Skidmore M. L., Foght J. M. and Sharp M. J. (2000) Microbial life beneath a high Arctic glacier. Appl. Environ. Microbiol. 66, 3214-3220.

Slater J. F., Currie L. A., Dibb J. E. and Benner B. A. (2002) Distinguishing the relative contribution of fossil fuel and biomass combustion aerosols deposited at Summit, Greenland through isotopic and molecular characterization of insoluble carbon. Atmos. Environ. 36, 4463-4477.

Sleighter R. L. and Hatcher P. G. (2008) Molecular characterization of dissolved organic matter (DOM) along a river to ocean transect of the lower Chesapeake Bay by ultrahigh resolution electrospray ionization Fourier transform ion cyclotron resonance mass spectrometry. Mar. Chem. 110, 140-152.

Southam A. D., Payne T. G., Cooper H. J., Arvanitis T. N. and Viant M. R. (2007) Dynamic range and mass accuracy of widescan direct infusion nanoelectrospray Fourier transform ion cyclotron resonance mass spectrometry-based metabolomics increased by the spectral stitching method. Anal. Chem. 79, 4595-4602.

Stenson A. C., Marshall A. G. and Cooper W. T. (2003) Exact masses and chemical formulas of individual Suwannee River fulvic acids from ultrahigh resolution electrospray ionization Fourier transform ion cyclotron resonance mass spectra. Anal. Chem. 75, 1275-1284.

Tranter M., Sharp M. J., Lamb H. R., Brown G. H., Hubbard B. P. and Willis I. C. (2002) Geochemical weathering at the bed of Haut Glacier d'Arolla, Switzerland - a new model. Hydrol. Processes 16, 959-993.

Tranter M., Skidmore M. and Wadham J. (2005) Hydrological controls on microbial communities in subglacial environments. Hydrol. Processes 19, 995-998.

Wadham J. L., Tranter M., Tulaczyk S. and Sharp M. (2008) Subglacial methanogenesis: a potential climatic amplifier? Global Biogeochem. Cycles 22, GB2021.

Wu Z., Rodgers R. P. and Marshall A. G. (2004) Two- and threedimensional van krevelen diagrams: a graphical analysis complementary to the kendrick mass plot for sorting elemental compositions of complex organic mixtures based on ultrahighresolution broadband fourier transform ion cyclotron resonance mass measurements. Anal. Chem. 76, 2511-2516.

Associate editor: Carol Arnosti 


\title{
Chapter 4
}

\section{Organic carbon export from the Greenland ice sheet}

\begin{abstract}
Rivers fed primarily by glacial meltwater potentially export a unique type of organic carbon to marine systems, distinct from non-glacially derived riverine export. Here we build on our earlier results that identified a high degree of temporal and spatial variability in the molecular-level composition of dissolved organic matter associated with the Greenland ice sheet (GrIS). We describe for the first time the bulk-level carbon composition of glacial meltwater from the GrIS. We investigate the dissolved (DOC) and particulate organic carbon (POC) concentration, age, and lability in the subglacial discharge throughout the melt season. By then scaling our measurements up across the ice sheet we suggest that the annual DOC flux $(0.16 \mathrm{Tg} / \mathrm{y})$ from the GrIS may be equivalent to that from a small Arctic river (e.g. Yana), and that the annual POC flux (1.9 Tg/y) may be comparable to that of a large Arctic river (e.g. Mackenzie). The DOC flux is derived primarily from the glacier base $(>75 \%$ ) in the early season, and from ice-melt (up to $100 \%$ ) at the peak of the meltseason. The POC flux is primarily derived from the subglacial environment throughout the meltseason. The early season glacier discharge contains higher dissolved organic carbon concentrations $(0.5-4.1 \mathrm{mg} / \mathrm{L})$, and exports younger carbon ( $\mathrm{DO} \Delta{ }^{14} \mathrm{C} \sim-250 \%$ ) compared to the peak season discharge, when the concentrations are lower $(0.1-0.6 \mathrm{mg} / \mathrm{L})$ and the $\Delta^{14} \mathrm{C}$ is more depleted $\left(\mathrm{DO} \Delta{ }^{14} \mathrm{C} \sim-400 \%\right)$. Conversely, the POC export $(1.4-13.2 \mathrm{mg} / \mathrm{L}$, $\mathrm{PO} \Delta{ }^{14} \mathrm{C} \sim-250 \%$ ) shows no temporal variation in either concentration or radiocarbon content throughout the meltseason. The dissolved carbon:nitrogen $(\mathrm{C} / \mathrm{N})$ ratios are also invariant with time, but are low ( 4-25), indicative of labile carbon, despite the antiquity of the DOC. The particulate $\mathrm{C} / \mathrm{N}$ ratios are more variable, but are similarly low $(\sim 8-21)$ during peak discharge. We use the dissolved ion loads in the glacial outflow to test the hypothesis that the type of DOC exported shifts with the seasonal evolution of the subglacial drainage system. These results illustrate that (1) different mechanisms control the DOC and POC flux from glacial systems; (2) chemically-distinct DOC pools are accessed by seasonally-evolving hydrological flow-paths; and (3) the GrIS can deliver labile, old carbon to downstream proglacial and marine environments.
\end{abstract}




\section{Introduction}

4 2009; Hood and Scott, 2008; Pautler et al., 2011). From a glacial-interglacial perspective,

5 in situ microbial metabolism of subglacial organic carbon beneath the Laurentide ice

6 sheet could produce $\mathrm{CO}_{2}$ and $\mathrm{CH}_{4}$ (Skidmore et al., 2000; Wadham et al., 2008) that may

7 have been released following deglaciation. From a present-day perspective, Hood et al.

8 (2010) has recently shown that glacier runoff along the Gulf of Alaska (GOA) is capable

9 of exporting ancient, labile dissolved organic carbon to surrounding coastal ecosystems.

10 This hypothesis has important implications for the coastal waters surrounding Greenland,

11 where glacier runoff contributes $\sim 500 \mathrm{~km}^{3}$ per year (Mernild et al., 2009), comparable to

12 the average annual discharge from the Lena River (Siberia) $\left(524-533 \mathrm{~km}^{3} / \mathrm{y}\right.$ ), the second

13 largest river contributor to the Arctic Ocean (Dittmar and Kattner, 2003). Yet, there are

14 very few studies of organic carbon export from these large ice sheets.

15 Extant studies have focused primarily on end-member carbon pools found on the

16 ice sheet surface and the bed, rather than on bulk meltwater runoff. These studies reveal

17 that in comparison to riverine, marine, and estuarine environments, organic carbon from

18 the ice sheet surface (i.e. supraglacial snow, ice, and meltwater) and base (basal ice) is

19 nitrogen-rich, containing proteinaceous and other biologically-derived compounds

20 (Bhatia et al., 2010; Dubnick et al., 2010; Pautler et al., 2011). The source of these

21 compounds is presumed to be in situ microbial communities on the glacier surface and at

22 the ice-bed interface (Bhatia et al., 2006; Carpenter et al., 2000; Hodson et al., 2008;

23 Skidmore et al., 2000).

24 Recent studies have shown that the majority of the meltwater draining the

25 Greenland ice sheet drains first to the bed, and is then discharged via a seasonally-

26 evolving subglacial (beneath the ice) drainage system (Bartholomew et al., 2010; Bhatia

27 et al., 2011; Das et al., 2008). Thus, an understanding of the meltwater outflow

28 (hydrology and volume) is essential to determine the ice sheet carbon contribution to

29 surrounding coastal oceans. Previous work in glacial systems indicates that transit 
30 through the subglacial environment alters the original character of ice-derived organic 31 carbon by adding a radiocarbon- $\left({ }^{14} \mathrm{C}\right)$ depleted, terrestrial-like component to the runoff

32 organic carbon (Barker et al., 2006; Bhatia et al., 2010; Dubnick et al., 2010; Hood et al.,

33 2009). However, the presence of abundant, uniquely-adapted subglacial microbes hints

34 that additional in situ microbial metabolism occurs at the glacier bed (Cheng and Foght,

35 2007; Sharp et al., 1999; Skidmore et al., 2005). Such subglacial microbial activity may

36 be able to utilize old organic carbon sources (Petsch et al., 2001), and add its own unique

37 brand of ${ }^{14} \mathrm{C}$-depleted, proteinaceous material to the organic carbon exported in glacial

38 runoff.

39 Previously, we investigated glacially-derived organic carbon using molecular-

40 level analyses (i.e. ultra-high resolution mass spectrometry) (Bhatia et al., 2010). Here,

41 we combine these observations with bulk-level analyses of abundance, age, and lability

42 of organic carbon in glacial meltwater draining a land-terminating GrIS outlet glacier. A

43 general consideration in the combination of bulk- and molecular-level analyses is that

44 each of these approaches has intrinsic advantages and disadvantages. Bulk measurements

45 such as $\mathrm{C} / \mathrm{N}$ ratios, stable isotopic compositions, and radiocarbon content provide

46 information on the major components comprising the organic carbon pool. However,

47 they are limited because they are not particularly sensitive to subsidiary constituents, and

48 can only differentiate broad source perspectives (Hedges et al., 1997). Conversely,

49 though molecular-level analyses are highly sensitive to specific components of the

50 organic carbon pool, they necessarily offer perspective on only select constituents or can

51 be biased by trace component contributions. By combining bulk- and molecular-level

52 approaches we aim to establish a comprehensive description of cycling and export of

53 organic carbon from the Greenland ice sheet.

In this study we investigate whether meltwater draining a land-terminating GrIS

55 outlet glacier exports chemically distinct organic carbon driven by seasonally-evolving

56 flow-paths, and whether processing in the proglacial environment alters the organic

57 carbon prior to export to a surrounding fjord. We utilize the major ion chemistry to gain

58 insight into the evolution of the subglacial drainage system, and the dominant subglacial 
59 chemical weathering regimes. We hypothesize that different temporal and spatial controls

60 act on glacially-derived organic carbon, with temporal controls dictating the type

61 (concentration, age, source, lability) of organic matter initially released from glacial

62 systems, and spatial controls influencing the organic matter alteration prior to export to

63 downstream environments. We investigate both the dissolved and particulate organic

64 carbon (DOC, POC) pools, since they are likely influenced by different dynamics in the

65 subglacial system, and have different fates in the marine environment. By definition,

66 POC sinks through the water column, transferring carbon from the surface to the deep

67 ocean, whereas DOC is concomitant with a water parcel, and is among the largest

68 exchangeable carbon pools on Earth (Hansell, 2002). Results from this study provide the

69 first radiocarbon measurements of organic carbon exported from the Greenland ice sheet,

70 and reveal new insight about carbon export from glacial environments.

\section{Field Site Description and Sampling Overview}

Our study site is located on the southwestern margin of the Greenland ice sheet

75 (Figure 1), approximately 125-km south of Jaokobshavn Isbrae and 120-km north of

76 Sondre Stromfjord. Our field area consists of three land-terminating outlet glaciers

77 (identified here as glaciers ' $\mathrm{M}$ ', ' $\mathrm{N}$ ', and ' $\mathrm{O}$ ') that drain into a large ( $\sim 10-\mathrm{km}$ in length)

78 proglacial lake (Thycho Brahe So / Qasigiatsigit), which discharges into Arfersiorfik

79 Fjord. The bedrock geology of this area consists primarily of quartz diorite rocks of the

80 Nagssugtqidian Orogenic Complex (K/Ar age 1790-1650 m.y.), most likely from an

81 intrusive sheet metamorphosed in its outer parts (Escher, 1971).

82 Daily stream samples were collected from the ' $\mathrm{N}$ ' glacier outflow during the late

83 spring (May 16 to June 1) and at the height of the summer melt season (July 10 to July

84 17) in 2008. Samples were generally collected in the afternoon (between 1 and 5 pm,

85 local Greenland time), but the precise collection times vary throughout the sampling

86 periods. Additional proglacial point samples were collected from the ' $\mathrm{M}$ ' and ' $\mathrm{O}$ ' glacier

87 floodplains; from a small closed basin in front of ' $N$ ' glacier (rain-water fed tarn, 
abbreviated 'Proglacial Tarn'); from the eastern shore of Qasigiatsigit Lake (abbreviated

89 'Proglacial Lake'); and from the lake outflow channel (abbreviated 'Lake Outflow').

90 Additional supraglacial point samples were collected from pooled meltwater on the

91 surface of 'N' glacier (300-m a.s.1., abbreviated 'N' Supraglacial) as well as from an

92 inland site (980-m, abbreviated 'Inland Supraglacial', 980-m) 70-km north-east of our

93 primary field site.

94 ' $\mathrm{N}$ ' glacier $\left(68^{\circ} 02^{\prime} 34^{\prime \prime} \mathrm{N}, 50^{\circ} 16^{\prime} 08^{\prime \prime} \mathrm{W}\right)$ is a small $\left(\sim 5 \mathrm{~km}^{2}\right.$ catchment $)$ outlet

95 glacier, whose physical characteristics, local meteorology, and hydrology have been

96 described in detail elsewhere (Bhatia et al., 2011). In brief, we proposed that the

97 subglacial drainage at ' $N$ ' glacier seasonally evolves from a distributed to channelized

98 flow system, in which the 'Early May' runoff drains a delayed flow dominated,

99 hydraulically inefficient network and the 'Late May' and 'July' runoff drains an

100 increasingly glacial ice-melt dominated, hydraulically efficient network [Bhatia et al.,

101 2011]. Based on results from this model, we identified three time periods throughout the

102 melt season, named 'Early May’ (May 18-24; JD 138-144), 'Late May’ (May 25-June 1;

103 JD 145-152), and 'July' (July 10-16; JD 191-198), with distinct hydrological regimes.

104 The Early May waters were comprised of $\geq 49 \%$ contribution from delayed flow waters,

105 whereas the Late May and July waters had between $12-36 \%$ and 5-17\% respective

106 contributions from delayed flow (Bhatia et al., 2011). These time periods have distinct

107 ion and carbon signatures as well, and so we retain usage of these terms throughout this

108 study.

109

110 3. Methods

111

112 All glassware was combusted at $450^{\circ} \mathrm{C}$ for at least 4 hours and all Teflon- and plastic113 ware was soaked overnight in $10 \%$ hydrochloric $(\mathrm{HCl})$ acid and rinsed extensively with

114 Milli-Q water. All samples were collected in bottles that were rinsed three times with

115 sample (or filtrate, as appropriate) prior to collection. All chemicals were obtained from

116 Thermo Fisher Scientific. Organic solvents were Optima grade or better. Concentrated 
117 acids were trace-metal grade or better. Samples for major ions, dissolved organic carbon 118 (DOC), total dissolved nitrogen (TDN), particulate organic carbon (POC), particulate 119 organic nitrogen (PON), and bulk organic radiocarbon were collected at approximately 120 the same time.

126 through $0.22 \mu \mathrm{m}$ cellulose acetate membranes (GE) with a polypropylene vacuum

127 filtration apparatus (Nalgene). Filtrate was collected, with minimal headspace, in 20-mL

128 HDPE scintillation vials (Nalgene). Samples were kept as cold as possible in the field,

129 and frozen upon return to the laboratory. $\mathrm{pH}( \pm 0.2$ units) was measured on-site

130 immediately following filtration with an YSI 556MPS hand-held meter. Dissolved

131 inorganic and organic anions and cations were measured by ion chromatography at

132 Queen's University's Facility for Biogeochemical Research on Environmental Change 133 and the Cryosphere (Fa.B.R.E.C.C.) (Kingston, ON, Canada). Anions and cations were 134 determined simultaneously on separate systems using a Dionex ICS 3000, following the 135 methods in Lafreniere and Lamoureux (2008). Analytical error for most analyses was less 136 than $10 \%$, based on replicate analyses of samples. Alkalinity (as $\mathrm{HCO}_{3}{ }^{-}$) was calculated 137 from the ionic charge deficit using the ion chromatography data. All cations (excluding $138 \mathrm{NH}_{4}^{+}$) and sulfate concentrations were corrected for their sea-salt derived components 139 using standard ratios to $\mathrm{Cl}^{-}$reported for these ions in seawater (Holland, 1978). The 140 residual crustal-derived component is denoted with an asterisk (*). Dissolved inorganic 141 nitrogen (DIN) is reported as the sum of $\mathrm{NO}_{3}{ }^{-} \mathrm{N}, \mathrm{NO}_{2}{ }^{-} \mathrm{N}$, and $\mathrm{NH}_{4}{ }^{+}-\mathrm{N}$. Phosphate $\left(\mathrm{PO}_{4}{ }^{3-}\right.$ 142 ) and silicate were measured on a Lachat QuickChem 8000 flow injection analyzer at the 143 Woods Hole Oceanographic Institution Nutrient Facility (Woods Hole, MA). Blanks 144 (Milli-Q water) and standards were analyzed routinely within each sample run. Standards 145 were made fresh daily using ACS certified chemicals (potassium phosphate and sodium 
146 fluorosilicate), and were compared daily to inter-calibration performance standards

147 (Quasiaeme and GEOTRACES). The coefficient of variability between replicate

148 standards was $<1 \%$ for both phosphate and silicate.

3.2. Dissolved Organic Carbon (DOC) and Total Dissolved Nitrogen (TDN)

151 Analyses

152 Samples for DOC and TDN analyses were collected in 250-mL glass bottles. All

153 samples were filtered on-site, within 24-h of collection, using a combusted glass filtration

154 apparatus, through a combusted pre-weighed glass-fiber pre-filter (GF/F; Whatman;

155 nominal pore-size 0.7- $\mu \mathrm{m}$ ) and a combusted 0.2- $\mu \mathrm{m}$ Anodisc membrane (Whatman). The

156 GFF pre-filter was stored for particulate organic carbon (POC) analyses. The 0.2- $\mu \mathrm{m}$

157 filtrate was acidified to $\mathrm{pH} 2$ with concentrated $\mathrm{HCl}$, and stored in a $40-\mathrm{mL}$ glass vial.

158 Samples were kept as cold as possible in the field and stored at $4^{\circ} \mathrm{C}$ upon return the

159 laboratory. DOC and TDN concentrations were quantified simultaneously as non-

160 purgeable organic carbon (NPOC) and total nitrogen by high temperature combustion

$161\left(680^{\circ} \mathrm{C}\right)$ with NDIR and chemiluminescent detection on a Shimadzu TOC-V $\mathrm{V}_{\mathrm{CSH}} / \mathrm{TNM}$

162 system equipped with a high sensitivity platinum catalyst (Shimadzu Scientific

163 Instruments). Samples were quantified using 5-point standard curves made with

164 potassium hydrogen phthalate and potassium nitrate. Blanks (Milli-Q water) and deep-sea

165 reference standards (provided by Prof. D. Hansell, University of Miami) were analyzed

166 routinely within each sample run, and reported concentrations are corrected for the mean

167 Milli-Q blank concentration. The limit of detection (based on instrument blanks) was

$168 \sim 0.02 \mathrm{mg} / \mathrm{L}$. Analytical error was less than $2 \%( \pm 0.01 \mathrm{mg} / \mathrm{L})$ for DOC, and typically less

169 than $5 \%( \pm 0.004 \mathrm{mg} / \mathrm{L})$ for TDN based on replicate injections. Dissolved organic

170 nitrogen (DON) was calculated as the difference between TDN and DIN $\left(\mathrm{NO}_{3}^{-}{ }^{-} \mathrm{N}^{-} \mathrm{NO}_{2}^{-}-\right.$

$171 \mathrm{~N}$, and $\mathrm{NH}_{4}{ }^{+}-\mathrm{N}$ ) (propagated error in DON was $\pm 0.006 \mathrm{mg} / \mathrm{L}$ ). DON concentrations less

172 than twice the propagated DON error were excluded from further analysis. This criterion

173 excluded four of the ' $N$ ' glacier outflow samples. DOC to DON ratios were then

174 calculated from division between these two parameters. 
3.3. Particulate Organic Carbon (POC) and Nitrogen (PON) Analyses Analyzer (ThermoQuest) at the Woods Hole Oceanographic Institution Nutrient Facility (Woods Hole, MA). An acetanilide certified standard (Microanalysis Limited) was used to make 9-point standard curve, and blanks (empty high purity tin discs) and standards were analyzed routinely within each sample run. Analytical error is less than $.01 \%$, based

\section{4 for nitrogen.}

185 The average discharge-weighted POC and DOC concentrations were calculated using the measured discharge at the time closest to the sample collection. The flux $(\mathrm{kg}$ $\mathrm{km}^{-2} \mathrm{~d}^{-1}$ ) of POC and DOC from ' $\mathrm{N}$ ' glacier was calculated as the product of the measured concentrations and the 24-h moving average discharge at the time closest to the collection time (from (Bhatia et al., 2011)).

\subsection{Bulk Organic Radiocarbon Analyses}

Samples for dissolved and particulate organic radiocarbon $\left(\mathrm{DO}^{14} \mathrm{C}\right.$ and $\mathrm{PO}^{14} \mathrm{C}$, respectively) analyses were collected in two 2-L Teflon bottles. One of the 2-L aliquots was used for $\mathrm{DO}^{14} \mathrm{C}$, and the second was used for $\mathrm{PO}^{14} \mathrm{C}$. The majority of the $\mathrm{DO}^{14} \mathrm{C}$ samples were filtered on-site immediately after collection, using the DOC protocol described above. The $0.2-\mu \mathrm{m}$ filtrate was stored in 1.25-L Teflon bottles. Aqueous samples were acidified to $\mathrm{pH}$ 2-3 with concentrated phosphoric acid $\left(\mathrm{H}_{3} \mathrm{PO}_{4}\right)$, kept as cold as possible in the field, and frozen upon return to the laboratory until analysis. The aliquot collected for $\mathrm{PO}^{14} \mathrm{C}$ was not filtered in the field, but was acidified, and frozen upon return to the laboratory.

Prior to radiocarbon analysis, $\mathrm{DO}^{14} \mathrm{C}$ and $\mathrm{PO}^{14} \mathrm{C}$ samples were thawed at $4{ }^{\circ} \mathrm{C}$, and analyzed at the National Ocean Sciences Accelerator Mass Spectrometry (NOSAMS) Facility (Woods Hole, MA). DOC was converted into carbon dioxide $\left(\mathrm{CO}_{2}\right)$ for $\Delta^{14} \mathrm{C}$ 
204 analysis using an ultraviolet (UV) oxidation and vacuum line system similar to that 205 described by Beaupre et al., (2007). Analytical blanks (UV-oxidized acidified milli-Q

206 water) and reference standards (oxalic acid II (modern ${ }^{14} \mathrm{C}$ ) and glycine hydrochloride

$207\left({ }^{14} \mathrm{C}\right.$ dead $\left.)\right)$ were analyzed routinely between samples. The analytical blank was $<0.3 \mu \mathrm{M}$.

208 The $\mathrm{PO}^{14} \mathrm{C}$ aliquots were thawed at room temperature, and filtered in the laboratory

209 through a combusted GFF pre-filter. The POC on the GFF pre-filter was converted into

$210 \mathrm{CO}_{2}$ for ${ }^{14} \mathrm{C}$ analysis using high temperature combustion at NOSAMS. For both $\mathrm{DO}^{14} \mathrm{C}$ 211 and $\mathrm{PO}^{14} \mathrm{C}$, a split of $\mathrm{CO}_{2}$ gas was taken for analysis of $\delta^{13} \mathrm{C}$ on a VG Prism-II Stable

212 Isotope Ratio Mass Spectrometer. The remaining $\mathrm{CO}_{2}$ gas was converted to graphite by

213 heating it in the presence of $\mathrm{H}_{2}$ gas and an iron catalyst. The graphite was pressed into

214 target cartridges and its ${ }^{14} \mathrm{C} /{ }^{12} \mathrm{C}$ was measured on the accelerator mass spectrometer at

215 NOSAMS. Radiocarbon results are normalized to a $\delta^{13} \mathrm{C}=-25 \%$ and are reported as

216 Fraction modern $\left(\mathrm{F}_{\mathrm{m}}\right)$, where 'modern' is defined as $95 \%$ of the $1950 \mathrm{AD}$ radiocarbon

217 concentration of NBS Oxalic Acid I (NIST-SRM-4990) normalized to a $\delta^{13} \mathrm{C}=-19 \%$

218 (see NOSAMS data reporting protocol for more details). The activity $\left(\Delta^{14} \mathrm{C}\right)$ is a measure

219 of the relative difference between the NBS Oxalic Acid I international standard and a

220 sample's radiocarbon activity after correction for both $\delta^{13} \mathrm{C}$ and radioactive decay

221 between 1950 and the year of measurement. On average, an enriched $\Delta^{14} \mathrm{C}$ signature

222 represents newly formed (younger) organic carbon, whereas a depleted $\Delta^{14} \mathrm{C}$ signature

223 represents relatively older organic carbon.

\section{Results} cations $\left(\mathrm{Na}^{+}, \mathrm{K}^{+}, \mathrm{Mg}^{+}, \mathrm{Ca}^{+}\right)$in the ' $\mathrm{N}$ ' glacier outflow stream are distinct in the three

230 periods of our isotope-mixing model (Figure 2), with the Early May samples being 231 markedly higher $(408-746 \mu \mathrm{eq} / \mathrm{L})$, compared to Late May $(125-329 \mu \mathrm{eq} / \mathrm{L})$ and July

$232(39.3-79.2 \mu \mathrm{eq} / \mathrm{L})$. Over the entire meltseason, the sum of crustal cation equivalents 
$233\left(\Sigma^{+}{ }_{\text {avg }}\right)$ averaged to $121 \mu \mathrm{eq} / \mathrm{L}$. However, the Early May samples are distinctly more

234 concentrated $\left(\Sigma_{\text {avg }}^{+}=282 \mu \mathrm{eq} / \mathrm{L}\right)$ compared to Late May $\left(\Sigma_{\text {avg }}^{+}=112 \mu \mathrm{eq} / \mathrm{L}\right)$ and July

$235\left(\Sigma^{+}{ }_{\text {avg }}=29 \mu \mathrm{eq} / \mathrm{L}\right)$. The silicate concentrations in the ' $\mathrm{N}$ ' glacier outflow stream mirrored 236 the trends seen in the major ion data in that the Early May waters had generally higher

237 concentrations $(23.1 \pm 7.9 \mu \mathrm{M})$, whereas the July waters were more dilute $(5.1 \pm 0.1 \mu \mathrm{M})$.

238 However, the Late May silicate concentrations were more variable $(15.4 \pm 8.7 \mu \mathrm{M})$, and

239 did not fit the temporal evolution pattern established by major ion data. An outlier sample

240 (excluded from Figure 2 for scaling purposes) that drained the lowest discharge waters on

241 May $21^{\text {st }}$, and had the greatest delayed flow contribution according to our isotope mixing-

242 model, had an especially high dissolved ion $(2354 \mu \mathrm{eq} / \mathrm{L})$, crustal cation $\operatorname{sum}\left(\Sigma^{+}=1161\right.$

$243 \mu \mathrm{eq} / \mathrm{L})$, and silicate $(45.4 \mu \mathrm{M})$ load.

244 Generally, sulfate $\left(\mathrm{SO}_{4}{ }^{2-*}\right)$ and bicarbonate $\left(\mathrm{HCO}_{3}{ }^{-*}\right)$ were the major $(5-45 \%)$

245 anionic contributors in all of the ' $\mathrm{N}$ ' stream waters, with nitrate $\left(\mathrm{NO}_{3}{ }^{-}\right)$and chloride $\left(\mathrm{Cl}^{-}\right)$

246 being minor $(\leq 2 \%)$ contributors (Table 1$)$. Notably, the Early May waters had a greater

247 percentage contribution of $\mathrm{SO}_{4}{ }^{2-*}(21 \%)$ compared to the Late May $(10 \%)$ and July

248 waters $(5 \%)$. Among the cations, calcium $\left(\mathrm{Ca}^{2+}\right)$ was the major $(16-21 \%)$ contributor

249 across the different time periods, followed by magnesium $\left(\mathrm{Mg}^{2+} *\right)$, sodium $\left(\mathrm{Na}^{+*}\right)$, and

250 potassium $\left(\mathrm{K}^{+} *\right) \cdot \mathrm{Mg}^{2+} *$ and $\mathrm{Na}^{+} *$ had generally consistent contributions in all the ' $\mathrm{N}$ '

251 glacier waters, between $13-14 \%$ and $8-10 \%$ respectively. However, $\mathrm{K}^{+} *$ was a

252 notably smaller contributor to the Early May waters (6\%), than to the Late May (10\%), 253 and July (11\%) waters.

254 We used associations between different ions to gain insight into the nature of the 255 subglacial chemical weathering regime, following Wadham et al., (2010b). The specific 256 ionic indices used were (i) the ratio of monovalent to divalent crustal cations in order to 257 assess the relative contributions of carbonate and silicate weathering (Figure 3a), (ii)

258 associations between $* \mathrm{SO}_{4}{ }^{2-}$ $\mathrm{vs}^{-} \mathrm{HCO}_{3}{ }^{-}$(Figure $3 \mathrm{~b}$ ) to examine whether microbial 259 oxidation of organic matter is occurring, and (iii) linear regressions between $\left(* \mathrm{Mg}^{2+}+\right.$ $\left.260 * \mathrm{Ca}^{2+}\right) \mathrm{vs} * \mathrm{SO}_{4}{ }^{2-}$ and $\mathrm{HCO}_{3}{ }^{-}$(Figure $\left.3 \mathrm{c}, \mathrm{d}\right)$ to estimate the extent to which sulfide 261 oxidation is coupled to carbonate dissolution. 


\section{2. $\quad$ DOC and POC concentrations}

The DOC concentrations at ' $\mathrm{N}$ ' glacier are generally dilute throughout the melt season (Figure 4a,b), with the exception of the May 21 outlier sample, which had a DOC

266 concentration of $4.1 \mathrm{mg} / \mathrm{L}$ (not shown in Figure 4a). Excluding this outlier, on average,

267 the DOC concentrations were slightly higher in Early May $(0.61 \pm 0.09 \mathrm{mg} / \mathrm{L})$, compared

268 to Late May $(0.39 \pm 0.08 \mathrm{mg} / \mathrm{L})$ and July $(0.27 \pm 0.15 \mathrm{mg} / \mathrm{L})$. However an elevated pulse

269 of DOC (0.62 mg/L), similar to concentrations found in Early May, was measured on

270 July 16 . There was no evident temporal trend in the POC concentrations of the ' $N$ '

271 outflow waters (average concentration $=3.5 \pm 1.1 \mathrm{mg} / \mathrm{L}$, or $1.0 \pm 0.5 \%$ organic carbon).

272 This average value excludes the May 21 outlier (excluded from Figure 4), which also had 273 a high POC concentration (13.2 mg/L, which equates to $9.9 \%$ organic carbon).

274 The DOC concentrations of the point samples collected from the proglacial area

275 in May and July, along with average ' $N$ ' and ' $M$ ' glacier outflow and ' $N$ ' supraglacial

276 samples are shown in Table 2. The 'N' supraglacial samples exhibited the lowest

277 concentration, whereas the proglacial samples (i.e. 'O' Glacier Floodplain, Proglacial

278 Lake, and Lake Outflow) were more concentrated. The Proglacial Lake sample had a

279 particularly high DOC concentration in the Early May point sample, though this

280 decreased substantially on June 1 and even further on July $13^{\text {th }}$. The POC concentrations

281 in the proglacial samples collected were generally lower than that in the glacier runoff

282 (Table 2).

4.3. Bulk Organic Radiocarbon

The $\delta^{13} \mathrm{C}$ and $\Delta^{14} \mathrm{C}$ signatures of a subset of supraglacial, subglacial, and 287 end-member sample, which was enriched in both $\delta^{13} \mathrm{C}$ and $\Delta^{14} \mathrm{C}$, the $\mathrm{DO} \delta^{13} \mathrm{C}$ values 288 range from -21.08 to $-28.49 \%$, whereas the $\operatorname{PO} \delta^{13} \mathrm{C}$ values only range over $\sim 2 \%$ ( $(-24.82$ 289 to $-26.96 \%$ ). The $\mathrm{DO} \Delta{ }^{14} \mathrm{C}$ range is ${ }^{14} \mathrm{C}$ depleted and similar (-210.7 to $-400.9 \%$ o) to the $290 \mathrm{PO} \Delta{ }^{14} \mathrm{C}$ range (-109.4 to $-351.7 \%$ ) with the exception of an enriched $\mathrm{DO} \Delta{ }^{14} \mathrm{C}$ sample 
$291(0.4 \%)$ from the 'O' glacier floodplain. Focusing on the subset of samples collected from 292 'N' glacier and its end-members (Figure 6), we noted that the 'N' supraglacial, 'N' 293 subglacial May, and proglacial tarn samples all fall on the 1:1 line between dissolved and 294 particulate radiocarbon, indicating that the dissolved and particle carbon dynamics are 295 coupled for these samples. Conversely, the ' $N$ ' subglacial July samples have depleted $296 \mathrm{DO} \Delta{ }^{14} \mathrm{C}$ values relative to their PO $\Delta{ }^{14} \mathrm{C}$ values, suggesting de-coupled dynamics. De297 coupling is also evident in the proglacial lake outflow (depleted $\mathrm{DO} \Delta{ }^{14} \mathrm{C}$ ) and ' $\mathrm{O}$ ' glacier 298 floodplain (enriched $\mathrm{DO} \Delta{ }^{14} \mathrm{C}$ ) samples (Figure 5).

299 In order to determine the DOC contribution and $\mathrm{DO} \Delta{ }^{14} \mathrm{C}$ signature of the basal 300 material exported in the ' $N$ ' glacier outflow, we employ our previous estimates of the 301 snow, ice, and delayed flow (basal) mass contributions to the ' $\mathrm{N}$ ' glacier outflow (Bhatia 302 et al., 2011). Combining this information with the DOC concentrations, we can solve for 303 the fractional DOC contribution of the snow, ice, and basal components using:

$$
f_{c}=q_{c} \times[D O C]_{c} /[D O C]_{o}
$$

304 where $f_{c}$ is the fractional DOC for a component (snow, ice, basal), $q_{c}$ is the proportional

305 flow contribution of a component (from the isotope mixing model), and [DOC] are the 306 respective DOC concentrations in a component $\left([\mathrm{DOC}]_{\mathrm{c}}\right)$ and the outflow $\left([\mathrm{DOC}]_{\mathrm{o}}\right)$. For 307 the ice and snow fractions, we did not have a complete dataset of coupled DOC and 308 radiocarbon values. Consequently, we solved for the ice fraction an average ice DOC 309 concentration from the surface of ' $\mathrm{N}$ ' glacier $(0.19 \pm 0.01 \mathrm{mg} / \mathrm{L})$ and the average $\mathrm{DO} \Delta{ }^{14} \mathrm{C}$ 310 of ice-melt from the 'Inland Supraglacial' site $(-233.9 \pm 32.7 \%)$. To calculate the snow

311 fraction, we assumed that the snow DOC concentration was similar to that of the average 312 glacial ice, and used the $\mathrm{DO} \Delta{ }^{14} \mathrm{C}$ of pooled early-season (frozen) meltwater on the 313 surface of ' $\mathrm{N}$ ' glacier (-340.1\%). Using the calculated fractional DOC contributions

314 (Figure 7a), the basal DO $\Delta{ }^{14} \mathrm{C}$ was estimated for the days when we had a bulk

315 radiocarbon value of the ' $\mathrm{N}$ ' outflow stream (May 19, July 12, and July 16). We defined 316 the mass-balance equation as follows:

$$
D O \Delta \Delta^{14} C_{\mathrm{o}}=\mathrm{f}_{\mathrm{s}} \times D O \Delta \Delta^{14} C_{\mathrm{s}}+\mathrm{f}_{\mathrm{i}} \times D O \Delta \Delta^{14} C_{\mathrm{i}}+\mathrm{f}_{\mathrm{b}} \times D O \Delta \Delta^{14} C_{\mathrm{b}}
$$


318 where the subscripts ' $\mathrm{o}$ ', 's', ' $\mathrm{i}$ ', and 'b' refer to the outflow, snow, ice, and basal

319 components respectively. We re-arranged this equation to solve for the $\mathrm{DO} \Delta{ }^{14} \mathrm{C}_{\mathrm{b}}$ term.

320 This yielded $\Delta{ }^{14} \mathrm{C}$-depleted basal DOC signatures on May 19 (-238.0\%) and July 16 (-

$321714.8 \%$ ), and a radiocarbon dead signature ( $\leq-1000 \%$ ) on July 12. Performing an

322 analogous calculation for the POC, we used $[\mathrm{POC}]_{\mathrm{i}}=0.43 \pm 0.19 \mathrm{mg} / \mathrm{L}, \mathrm{PO} \Delta \Delta^{14} \mathrm{C}_{\mathrm{i}}=-111.4$

$323 \pm 2.8 \%$, and $\mathrm{PO} \Delta{ }^{14} \mathrm{C}_{\mathrm{s}}=-351.7 \%$ to solve for the fractional contributions from the snow,

324 ice, and basal reservoirs to the runoff POC (Figure 7b). Solving for the basal PO $\Delta^{14} \mathrm{C}$,

325 we find depleted basal POC signatures on May 19 (-258.6\%), July 12 (-288.6\%), and

326 July $14(-281.1 \%)$.

\subsection{Carbon:Nitrogen Ratios}

The DOC:DON ratios among the ' $\mathrm{N}$ ' glacier outflow samples range widely from 4.3 to 24.5 , and there is no evident temporal trend between the early May, late May, and July samples (data not shown). The supraglacial and proglacial data is primarily limited to only a few samples, but based on these few values, we observe a general increase in the DOC:DON ratios from the ice edge to the lake outflow (Figure 8). However, we should note that where we have multiple measurements across temporal periods, the range of values is large (e.g. 4.5 to 16.2 for the 'N' Supraglacial, 6.0 to 30.7 for the ' $\mathrm{M}$ ' glacier outflow, 4.3 to 24.5 for the ' $\mathrm{N}$ ' glacier outflow, and 9.5 to 50.0 for the proglacial lake). The POC:PON ratios of the ' $N$ ' glacier outflow show a clearer temporal trend, in that the May samples are variable (range: 7.9 to 66.4 ), whereas the July samples are more consistently lower (range: 8.4 to 21.1 ; Figure 8 ). The PON of the ' $\mathrm{N}$ ' supraglacial ice and ' $\mathrm{O}$ ' glacier floodplain samples were below the limit of detection. The ' $\mathrm{M}$ ' glacier outflow POC:PON values ranged from 8.9 to 15.5 .

\section{Discussion}


The major ion hydrochemistry of the ' $\mathrm{N}$ ' glacier runoff is broadly similar in

348 composition to that previously reported from other glacial systems, but is much more

349 dilute $\left(\Sigma_{\text {avg }}^{+} 121 \mu \mathrm{eq} / \mathrm{L}\right)$ than typical glacier runoff $\left(\Sigma_{\text {avg }}^{+} \sim 700 \mu \mathrm{eq} / \mathrm{L}\right)$ (Skidmore et al.,

350 2010), suggesting a comparatively unreactive bedrock on shorter subglacial residence

351 times. For comparison, the $\Sigma^{+}$avg of river waters in the Mackenzie River basin is 2900

$352 \mu \mathrm{eq} / \mathrm{L}$ (Millot et al., 2003). Generally, glacial runoff is a dilute $\mathrm{Ca}^{2+}-\mathrm{HCO}_{3}{ }^{-}-\mathrm{SO}_{4}{ }^{2-}$

353 dominated mixture, with varying contributions from $\mathrm{Na}^{+}$and $\mathrm{Cl}^{-}\left(\Sigma^{+}\right.$ranging from 10 to

$3543500 \mu \mathrm{eq} / \mathrm{L})$ (Tranter, 2003). This composition reflects the fact that subglacial chemical

355 weathering is typically dominated by carbonate (calcite) hydrolysis followed by sulfide

356 oxidation coupled to carbonate dissolution (Tranter, 2003). Previous studies in alpine

357 catchments have shown that even when a bedrock is dominated by silicates, trace

358 carbonates are still preferentially weathered, generating a high ratio of carbonate to

359 silicate dissolution ( 5:1 in glacial catchments (Tranter, 2003)). We calculated the ratio

360 of divalent $\left(* \mathrm{Ca}^{2+}+* \mathrm{Mg}^{2+}\right)$ to monovalent $\left(* \mathrm{Na}^{+}+* \mathrm{~K}^{+}\right)$crustal cations (Figure $3 \mathrm{a}$ ) because

$361 \mathrm{Na}^{+}$and $\mathrm{K}^{+}$are pre-dominantly derived from silicate dissolution (Wadham et al., 2010b)

362 and thus ratio values $<1$ indicate preferential silicate dissolution. Although ' $\mathrm{N}$ ' glacier

363 drains a silicate-dominated bedrock, the average divalent:monovalent ratio is 1.8 ,

364 suggesting that trace carbonates are being weathered preferentially over the silicate

365 bedrock. This is consistent with previous work (Wadham et al., 2010b), although 'N'

366 glacier has a greater silicate weathering index (lower divalent:monovalent ion ratio)

367 compared to other glacial catchments (Wadham et al., 2010b), particularly in late May

368 and July $\left(\left(* \mathrm{Ca}^{2+}+* \mathrm{Mg}^{2+}\right) /\left(* \mathrm{Na}^{+}+* \mathrm{~K}^{+}\right)_{\text {avg }}=1.5\right)$. The higher divalent:monovalent ion ratio

369 in the Early May runoff $\left(\left(* \mathrm{Ca}^{2+}+* \mathrm{Mg}^{2+}\right) /\left(* \mathrm{Na}^{+}+* \mathrm{~K}^{+}\right)\right.$avg $\left.=2.6\right)$ hints that these waters may

370 drain a different subglacial environment, in which proportionally greater carbonate

371 dissolution occurs. This hypothesis is reinforced by the strong relationship between

$372 * \mathrm{SO}_{4}{ }^{2-}$ and $\left(* \mathrm{Mg}^{2+}+* \mathrm{Ca}^{2+}\right)$ for the Early May waters (Figure 3c) which are indicative of

373 sulfate derived from saturated porewaters along the ice/land margin (Wadham et al.,

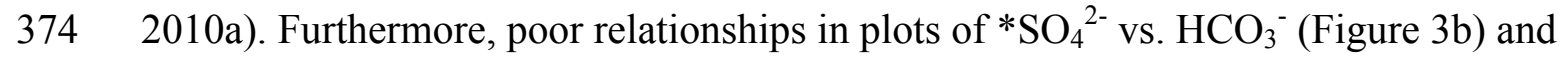

$375 \mathrm{HCO}_{3}{ }^{-}$vs. $\left(* \mathrm{Mg}^{2+}+* \mathrm{Ca}^{2+}\right)($ Figure $3 \mathrm{~d})$ in Early May waters compared to the stronger 
376 relationships in the late May and July waters indicate that later discharge waters are not

377 draining saturated marginal porewaters (Wadham et al., 2010a) but instead may be

378 accessing unsaturated headward regions.

\subsubsection{Carbon export over a meltseason}

The organic carbon concentrations measured in the ' $\mathrm{N}$ ' glacier runoff (Figure 4) are dilute, but within the range $\left(<1 \mathrm{~m} \mathrm{C} \mathrm{L}^{-1}\right)$ previously reported for runoff from other glacial systems (Barker et al., 2006; Hood et al., 2009; Lafreniere and Sharp, 2004). The organic carbon in the ' $\mathrm{N}$ ' glacier runoff is an amalgamation of supraglacial, englacial, and subglacial sources. Using our model results (Bhatia et al., 2011) in combination with the organic carbon concentrations (section 4.3), we can estimate the mass contributions from the snow, ice, and basal pools to the runoff DOC and POC (Figure 7). Since the supraglacial (snow, ice) and englacial environments share ice-melt as their primary carbon source, we can roughly assume a similar mass contribution from the englacial source as found in the supraglacial samples. Doing this we find that approximately $>75 \%$ of the DOC, on average, in the early May samples is likely derived from the subglacial environment. In contrast in late May this contribution decreases to $\sim 30 \%$, with the remaining majority from supraglacial and englacial sources. The July runoff, on average, could be entirely derived from the supraglacial and englacial sources. However, individual July samples with DOC concentrations above $0.2 \mathrm{mg} / \mathrm{L}$ are an exception, and likely have some subglacial contribution (between $\sim 10-30 \%$ ). We should also note that the May 21 outlier sample $([\mathrm{DOC}]=4.1 \mathrm{mg} / \mathrm{L})$ is a clear exception, as the carbon mass observed on that day almost certainly has a large subglacial component. From a POC mass balance perspective, since the supraglacial and englacial sources contribute, on average, only $\sim 10 \%$ of the mean ' $N$ ' glacial runoff POC concentration, we conclude that the majority $(\sim 90 \%)$ of the runoff POC originates in the subglacial environment

404 subglacial in origin. 
The seasonal flux of DOC and POC generally mimics the discharge curve (Figure $4 \mathrm{c}, \mathrm{d})$, illustrating that discharge, rather than concentrations, drives the mass flux of DOC and POC from ' $\mathrm{N}$ ' glacier. Thus, the majority of glacially-derived organic carbon is annually released in a relatively small period of time (i.e. a few months), during the peak of the summer melt-season. Generally, the POC fraction is the quantitatively important pool as it comprises, on average, between 84 and 93\% of the total organic carbon mass flux. The proportional average contribution from the DOC pool diminishes from Early May (16\%) to Late May (11\%) and July (7\%), as discharge increases. This is the opposite of major riverine systems (e.g. the Amazon), where the DOC is exported in excess of the POC (e.g. DOC/POC 1.8) (Hedges et al., 1997). However, since a portion of the POC pool likely quickly settles out upon exit from the glacier terminus, the DOC pool, as the mobile phase, may still have important downstream effects depending on its lability.

\subsubsection{Mobilization of subglacial organic carbon pools over a meltseason} outflow samples analyzed in this study were all depleted in radiocarbon in both May and July (Figure 5), suggesting relict carbon sources or new microbial production based on depleted in/organic carbon stores. Few studies exist for robust comparison with these data

424 into the Gulf of Alaska. The radiocarbon values for DOC exported in the 'N' glacier

425 runoff were more depleted in $\Delta^{14} \mathrm{C}$ than those from large Arctic rivers, but within the 426 range of $\mathrm{DO} \Delta^{14} \mathrm{C}$ signatures previously reported from runoff draining glaciers along the

427 Gulf of Alaska (Figure 5). Comparatively, the ' $\mathrm{N}$ ' glacier runoff $\mathrm{PO} \Delta{ }^{14} \mathrm{C}$ signatures were 428 within the range of previously reported POC from small mountainous rivers (Figure 5). In 429 riverine systems, DOC is derived from recently fixed plant organic matter or is generated 430 during chemical weathering of near surface soil horizons (Benner et al., 2004; Raymond 431 and Bauer, 2001b). Conversely, POC generally enters through mechanical weathering of 432 underlying soil and rock material (Raymond and Bauer, 2001b). Since chemical 433 weathering is a process generally associated with new production, DOC is often younger 
434 than POC in river systems, being enriched in radiocarbon or only mildly depleted 435 (Raymond and Bauer, 2001b). In contrast, POC is often considerably depleted in 436 radiocarbon due to contribution from antiquated carbon sources such as old soil horizons, 437 sedimentary fossil carbon, and sorbed petroleum (Raymond and Bauer, 2001b). Our data 438 contrast with river systems in that the $\mathrm{DO} \Delta{ }^{14} \mathrm{C}$ is more depleted than $\mathrm{PO} \Delta{ }^{14} \mathrm{C}$ and grows 439 increasingly so over the meltseason. Thus we must invoke a different mechanism to 440 explain the glacial runoff $\mathrm{DO} \triangle{ }^{14} \mathrm{C}$ values.

441 We hypothesize that the different $\mathrm{DO} \triangle{ }^{14} \mathrm{C}$ signatures in the May and July runoff

442 is a function of seasonally-evolving subglacial hydrological conditions, whereas the 443 constant $\mathrm{PO} \Delta{ }^{14} \mathrm{C}$ signature is that of the bulk material overridden by the ice mass. For the 444 DOC pool, this hypothesis is consistent with our previous work at ' $N$ ' glacier speculating 445 that the seasonal head-ward evolution of the subglacial drainage system resulted in 446 quickly transiting meltwaters accessing relict subglacial organic carbon stores in July 447 (Bhatia et al., 2010). A mass-balance calculation of the July basal $\mathrm{DO} \Delta{ }^{14} \mathrm{C}$ (see section 448 4.3) further supports this hypothesis, revealing that the late-season waters are accessing 449 antiquated, radiocarbon-dead basal material and/or contain radiocarbon-dead surface450 derived hydrocarbons. Since July runoff waters are characterized by very low DOC 451 concentrations, even a small mass contribution of $\Delta{ }^{14} \mathrm{C}$-dead material would yield a more 452 depleted bulk DO $\Delta{ }^{14} \mathrm{C}$ signature. Conversely, in May, when the subglacial drainage 453 system contains a large delayed flow component, and is potentially draining saturated 454 porewaters, the basal $\mathrm{DO} \Delta{ }^{14} \mathrm{C}(-243.6 \%)$ is similar to that of the outflow signature ($455245.9 \%$ ), indicating that the $\mathrm{DO} \triangle{ }^{14} \mathrm{C}$ exported in the May outflow is derived primarily 456 from marginal porewaters. Thus, the DOC pool is sensitive to shifts between the 457 distributed and channelized drainage systems because its contents are mobile, and its 458 concentrations are very low.

459 The majority of the ' $\mathrm{N}$ ' runoff $\mathrm{PO} \Delta{ }^{14} \mathrm{C}$ signatures are within the range of 460 previously reported $\Delta{ }^{14} \mathrm{C}-\mathrm{POC}$ from small mountainous rivers. Thus, we propose that, 461 akin to small mountainous rivers, a relict soil/rock contribution from the subglacial 462 environment, in this case, yields the depleted glacial runoff $\mathrm{PO} \Delta{ }^{14} \mathrm{C}$ signature (Raymond 
463 and Bauer, 2001b). A mass balance calculation of the basal $\mathrm{PO} \Delta{ }^{14} \mathrm{C}$ pool (-262 to -

$464299 \%$ ) confirms that the bulk runoff $\mathrm{PO} \Delta{ }^{14} \mathrm{C}$ signature (-257 to $-263 \%$ ) is primarily

465 driven by the subglacial contribution. In comparison to the DOC pool, the runoff POC

466 pool is much larger (in mass), and thus is less susceptible to variable mass contributions

467 resulting from changes in the subglacial drainage system. As a result, its radiocarbon

468 content is invariant with hydrology and the POC in general is affected more by regional-

469 scale glacier advance and/or retreat than by hydrology.

\subsubsection{Organic carbon source and lability}

The bulk-level $\Delta{ }^{14} \mathrm{C}$ differences between the May and July ' $\mathrm{N}$ ' outflow samples

474 exported in late May and July differs on a molecular level (Bhatia et al., 2010). Using

475 ultra-high resolution mass spectrometry we showed that the July (12 and 16) samples had

476 a higher proportion of lignin and terrestrial-like material, consistent with the flushing of

477 relict organic carbon from overridden soil and vegetation, as discharge increases

478 throughout the summer meltseason. Comparatively, the organic carbon in a May 31

479 outflow, though still possessing terrestrial-like compounds, had a distinct protein-like and

480 lipid-like signature. We previously ascribed these signatures to microbial metabolic

481 influence on DOC composition (Bhatia et al., 2010). However, this differentiation

482 between the May and July runoff was not evident from the bulk $\delta^{13} \mathrm{C}$ signature, which

483 can also be used to glean source information. The $\mathrm{DO}^{13} \mathrm{C}$ signatures of ' $\mathrm{N}$ ' glacier

484 runoff sampled on May 19, July 12, and July 14 (-23.7\% to $-25.8 \%$, Figure 3 ) all fell

485 within the range of a terrestrial (C3 plant) derivation (Hedges et al., 1997).

486 Regardless of source, the dissolved and particulate $\mathrm{C}: \mathrm{N}$ ratios can be used to

487 give a broad perspective on the lability of organic carbon. Generally, proteins,

488 carbohydrates/sugars, and plant tissues have C:N ratios of $\sim 4, \sim 15-20$, and $\sim 20-500$,

489 respectively (Hedges et al., 1986). Since material such as proteins and carbohydrates is

490 generally more reactive to microbial metabolism, lower ratios typically correlate with

491 more labile material (Hunt et al., 2000). Although there is no temporal trend among the 
'N' glacier outflow samples with respect to the DOC:DON ratios, the overall range is

493 relatively low ( 4-25). The DOC:DON ratios reported here from ' $N$ ' glacier are

494 consistent with previous results from runoff draining glaciers along the GOA (DOC:DON

$495<20$ ), suggesting that glaciers generally may be a source of nitrogen-rich DOC (Hood

496 and Berner, 2009). Although it is difficult to assess lability at the bulk-level based solely

497 on DOC:DON ratios, this hypothesis is bolstered by our previous work using ultra-high

498 resolution mass spectrometry, showing that (i) protein-like and lipid-like compounds are

499 present in both the May and July 'N' glacier outflow samples, and (ii) that nitrogen-

500 containing molecules may be major contributors to glacial DOM, compared to riverine

501 and open ocean DOM (Bhatia et al., 2010; Kujawinski et al., 2009). Finally, though we

502 have lack complementary mass spectrometry analysis of the POC fraction, similar

503 POC:PON ratios in the July runoff (range: 8.3 to 21.1 ) hints that the bulk material from

504 which the dissolved load is derived may be nitrogen-rich (Figure 8). However, the

505 variability within the May runoff POC:PON ratios (range: 7.9 to 66.4) is perplexing, and

506 requires additional class-specific analyses (e.g. lipid biomarkers) of the POC pool to

507 more fully determine its composition.

5.1.5. Evidence for microbially-mediated subglacial chemical weathering?

Previous studies have suggested that nitrogen-rich DOM in glacial systems

511 originates from proteinaceous material associated with subglacial microbial communities

512 (Barker et al., 2006; Hood and Scott, 2008; Lafreniere and Sharp, 2004). To investigate

513 this hypothesis in our system we examined the bulk runoff hydrochemistry for evidence

514 of widespread microbial activity facilitating subglacial chemical weathering beneath ' $N$ '

515 glacier. This approach relies heavily on the supposition that subglacial weathering at ' $\mathrm{N}$ '

516 glacier is similar to that of other glacial systems, and can be challenging due to

517 differential impact of competing subglacial chemical weathering reactions on the bulk

518 runoff ion chemistry. Nonetheless, previous studies in glacial environments have shown

519 that a runoff signature significantly perturbed from that expected from a purely abiotic

520 system can be indicative of active microbial communities. Two reactions which have 
521 been previously documented to be microbially-mediated in subglacial environments are 522 (i) oxidation of organic matter, and (ii) sulfide oxidation (Wadham et al., 2010b).

523 Carbonate hydrolysis is generally the first reaction to occur when dilute 524 supraglacial meltwater interacts with the glacier bed, and results in the rapid generation 525 of $\mathrm{HCO}_{3}{ }^{-}$and $* \mathrm{Ca}^{2+}$ independently of sulfate (Wadham et al., 2010b). Thus, a plot of $526 * \mathrm{SO}_{4}{ }^{2-}$ vs $\mathrm{HCO}_{3}{ }^{-}$would ideally have a y-intercept of $\sim 220 \mu \mathrm{eq} / \mathrm{L}$ (Wadham et al., 2010b), 527 the theoretical solubility of calcite in pure water at $0^{\circ} \mathrm{C}$ (Tranter et al., 2002). A y528 intercept above $220 \mu \mathrm{eq} / \mathrm{L}$ suggests an additional source of $\mathrm{CO}_{2}$ to the subglacial 529 meltwaters, most likely from microbial oxidation of organic matter (Wadham et al., 530 2010b). Among the 'N' outflow samples, only the Late May and July samples have 531 significant linear relationships between $* \mathrm{SO}_{4}{ }^{2-}$ and $\mathrm{HCO}_{3}{ }^{-}$and both have y-intercepts 532 well below $220 \mu \mathrm{eq} / \mathrm{L}$ (Figure 3a). These low y-intercepts indicate little (or no) 533 micobially-generated $\mathrm{CO}_{2}$ and suggest that the silicate bedrock underneath ' $\mathrm{N}$ ' glacier is 534 not favorable to microbial colonization. This result is not unexpected considering that 535 hard bed-rock (e.g. silicate) systems are less amenable to large-scale microbial 536 colonization than systems with softer bedrocks (e.g. carbonate) (Wadham et al., 2010b).

537 However, the higher DOC concentrations in early May, and in the May 21 outlier sample 538 particularly, hint that an available organic carbon source for microbial oxidation is 539 present in the ' $\mathrm{N}$ ' subglacial environment, particularly in the early season.

$540 \quad$ High sulfate concentrations in glacial runoff have previously been found to be a 541 consequence of microbially-mediated anoxic sulfide oxidation. In oxic sulfide oxidation 542 the typical rate-limiting step is the oxidation of $\mathrm{Fe}^{2+}$ to $\mathrm{Fe}^{3+}$ but since this step can be 543 microbially mediated, the rate of sulfide oxidation can thereby be exponentially increased 544 above that of abiotic systems (Sharp et al., 1999). Sulfide oxidation consumes oxygen, 545 and microbial mediation hastens this process, thus driving regions of the subglacial 546 system anoxic. The maximum sulfate concentration that can be generated from sulfide 547 oxidation using oxygen-saturated waters at $0^{\circ} \mathrm{C}$ is $\sim 400 \mu$ eq/L (Tranter et al., 2002).

548 Thus, runoff $\mathrm{SO}_{4}{ }^{2-}$ concentrations well above this value suggest alternative oxidizing 549 agents (e.g. $\mathrm{Fe}^{3+}$ ) are present at the glacier bed, and additional sulfate contributions may 
550 be generated via microbially-mediated anoxic sulfide oxidation (Tranter et al., 2002).

551 The 'N' glacier outflow waters exhibit sulfate concentrations (1.5 - $162 \mu \mathrm{eq} / \mathrm{L})$ well

552 below $400 \mu \mathrm{eq} / \mathrm{L}$, thereby providing no evidence for microbially-mediated anoxic sulfide

553 oxidation. However, Tranter (2003) noted that it is difficult to ascertain the subglacial

554 biogeochemical environment solely from bulk runoff waters. For example, at Haut

555 Glacier d'Arolla, a similarly-sized Swiss Alps glacier with a schist-gneiss-amphibolite

556 bedrock, sulfate concentrations in the bulk runoff are typically less than $200 \mu \mathrm{eq} / \mathrm{L}$, but

557 borehole waters sampled at the bed could have a sulfate concentrations up to $1200 \mu \mathrm{eq} / \mathrm{L}$

558 (Tranter et al., 2002). An exception to dilute sulfate concentrations in the ' $N$ ' glacier

559 runoff was the May $21^{\text {st }}$ sample which drained the lowest measured discharge waters with

560 the largest modeled delayed (basal) flow component (Bhatia et al., 2011). The sulfate

561 concentration in this sample was $929 \mu \mathrm{eq} / \mathrm{L}$, thus hinting that some component of the ' $\mathrm{N}$ '

562 subglacial hydrological system may drain regions that support microbially-mediated

563 anoxic sulfide oxidation.

564 In summary, if a microbially community is present, there does not appear to be

565 sufficient activity to impact the bulk signature of the major ion chemistry in a similar

566 fashion to that previously observed in some glacial systems. Thus, any subglacial

567 microbial community at ' $N$ ' glacier is likely not large enough to mediate large-scale

568 subglacial weathering processes. Yet, the lack of such a hydrochemical signal, does not

569 negate the possibility that a microbial community exists beneath ' $N$ ' glacier. The

570 hydrochemistry and DOC concentrations observed in the base flow (May $21^{\text {st }}$ ) sample is

571 compelling evidence that microbial activity is able to influence subglacial DOM

572 character in specific micro-environments (e.g. saturated porewaters), which only impact

573 the bulk runoff signature in the early (low discharge) season. This supposition is further

574 supported by our molecular-level composition analysis of runoff DOM, which revealed a

575 discernable microbial signature in the May runoff that was swamped by an overwhelming

576 terrestrial signature in July runoff (Bhatia et al., 2010).

577

578 5.1.6. Decoupling of radiocarbon and lability in glacial systems? 
An alternative hypothesis for the low $\mathrm{C}: \mathrm{N}$ ratios, and proteinaceous material typical of glacial rivers is that labile DOM fractions remain from the soils and vegetation initially overrun during past periods of glacial advance. This hypothesis explains both the depleted DO $\Delta^{14} \mathrm{C}$, typical of glacial systems (Hood et al., 2009), and the observed C:N ratios. In oxygenated systems, radiocarbon signature and lability are coupled concepts, since material depleted in radiocarbon is considered to be old, or relict, organic carbon whose labile components have long-since been consumed (Raymond and Bauer, 2001a). However, in glacial systems, we propose that these concepts may be decoupled. Although the organic matter may be depleted in radiocarbon, owing to its ultimate derivation from previously overridden soils and vegetation, it may still possess labile components since the ice cover could inhibit the full range of metabolic reactions present in oxygenated soil environments. In effect, the glacier or ice sheet acts as a freezer, preserving the labile components of the organic matter, which are then exported in the runoff.

\subsection{Proglacial processing of glacially-derived organic carbon}

Though we possess limited proglacial samples, they are intriguing as they hint

595 that glacially derived DOC undergoes significant transformation in land-terminating GrIS systems prior to export to the surrounding marine environments. Our field site is typical of many land-terminating glacier systems along the western margin of the ice sheet where several glacial rivers transmit through a floodplain/proglacial region, into a large proglacial lake, before eventually emptying into a fjord. The general increase in the

600 dissolved C:N ratios from the ice surface to the proglacial lake outflow (Figure 8) may 601 broadly indicate that glacially-derived DOM becomes less labile as it traverses through 602 the proglacial environment. However, the range of DOC:DON ratios observed within 603 each sample type indicates that variability can be large, and thus more frequent sampling 604 would be needed to confirm this trend. In this study the 'O' glacier floodplain sample 605 represents our best analogue for the processing that occurs in glacial runoff prior to entry 606 into the proglacial lake. From this sample, it appears that floodplain processing adds 607 newly produced DOC, evidenced by a significantly more enriched radiocarbon content 
$608\left(\Delta^{14} \mathrm{C}-\mathrm{DOC}>0\right)$. The DOC undergoes further transformation in the proglacial lake. Our 609 analysis of the proglacial lake dynamics was limited to two samples (Proglacial Lake and 610 the Lake Outflow), but from these, it seems that the most labile fractions of DOC was 611 consumed in the lake, as the concentrations decreased and the $\mathrm{DO} \Delta{ }^{14} \mathrm{C}$ became more 612 depleted down the lake length. Interestingly, the PO $\Delta{ }^{14} \mathrm{C}$ signature between the 613 Proglacial Lake and Lake Outflow becomes more enriched, perhaps suggesting that as 614 the labile DOC fractions are consumed, new production adds enriched POC. This 615 contention is also supported by the low POC:PON ratios, where the nitrogen could be 616 derived from new production. 5.3 Delivery of glacially-derived organic carbon to the oceans The surface runoff from the Greenland ice sheet is estimated to be on the order of $620 \sim 500 \mathrm{~km}^{3} / \mathrm{y}$ (Mernild et al., 2009) which is comparable to the combined annual discharge 621 from the four major pan-Arctic North American rivers (Mackenzie, Yukon, Peel, Beck) 622 as averaged over 1970-2008 (Shiklomanov, 2009). Using this discharge estimate and the 623 average discharge-weighted DOC $(0.32 \mathrm{mg} / \mathrm{L})$ and POC $(3.7 \mathrm{mg} / \mathrm{L})$ concentrations 624 measured at ' $\mathrm{N}$ ' glacier, we can estimate an annual export of $0.16 \mathrm{Tg}$ of DOC and $1.9 \mathrm{Tg}$ 625 of POC from the Greenland ice sheet. This DOC flux is equivalent to a recent estimate 626 from the Gulf of Alaska glaciers ( $0.13 \mathrm{Tg}$ /year) and smaller Arctic rivers (e.g. Olenek: $6270.32 \mathrm{Tg} / \mathrm{y}$, Yana: $0.09 \mathrm{Tg} / \mathrm{y}$ ), but lower than that from the four major rivers draining into 628 the Arctic Ocean (Yenisey: 4.1-4.9 Tg/y, Lena: 3.4-4.7 Tg/y, Ob: 3.1-3.2 Tg/y, 629 Mackenzie: $1.3 \mathrm{Tg} / \mathrm{y}$ ) (Dittmar and Kattner, 2003). Conversely, our estimated Greenland 630 ice sheet POC flux is equivalent to that from the Mackenzie (1.8-2.1 Tg/y), the principal 631 river POC contributor to the Arctic ocean (Dittmar and Kattner, 2003). Thus, DOC flux 632 from the Greenland ice sheet is similar to that of a minor Arctic river, whereas the POC 633 flux is comparable to that from the major river contributor.

634 Similar to Arctic river systems, the majority of the annual organic carbon exported 635 by glacial systems occurs during a short time period, when discharge is at its peak.

636 However, in contrast to river systems (Benner et al., 2004), the base flow exports 
637 comparatively younger, but still ${ }^{14} \mathrm{C}$-depleted DOC (-245.9\%), whereas the peak flow 638 exports older, more ${ }^{14} \mathrm{C}$-depleted DOC (-395.3 to $-400.9 \%$ ). The average surface

$639 \mathrm{DO} \Delta{ }^{14} \mathrm{C}$ signature in surface ocean waters is between $-150 \%$ and $-400 \%$; in deep ocean

640 waters $\mathrm{DO} \triangle{ }^{14} \mathrm{C}$ becomes more depleted, down to $-540 \%$ in North Pacific Deep Water

641 (McNichol and Aluwihare, 2007). Glacial systems also export a ${ }^{14} \mathrm{C}$ depleted POC pool (-

$642257 \%$ to $-263 \%$ ) compared to the surface ocean $\mathrm{PO} \Delta{ }^{14} \mathrm{C}$ signature, which is generally

643 enriched in $\Delta^{14} \mathrm{C}$ (Druffel and Bauer, 2000; McNichol and Aluwihare, 2007), and the

644 deep ocean $\mathrm{PO} \Delta{ }^{14} \mathrm{C}$ (e.g. - $111 \%$ in the Southern Ocean) (Druffel and Bauer, 2000). Thus,

645 peak flow glacial runoff may contribute a pre-aged end-member to the oceanic DOC and

646 POC pools. On a global scale, any glacial contribution is likely orders of magnitude too

647 small in comparison to the standing surface organic carbon inventory to influence the

648 oceanic $\mathrm{DO} \Delta{ }^{14} \mathrm{C} / \mathrm{PO} \Delta{ }^{14} \mathrm{C}$ signatures. However, export of glacially-derived organic

649 carbon from land-terminating Greenland ice sheet glaciers may still have localized

650 impact in the coastal North Atlantic and Arctic Oceans. The likelihood and broader

651 implications of this export depend on whether the labile fractions of glacial organic

652 carbon survive biogeochemical processing in the proglacial and estuarine regions. Our

653 results hint that a significant proglacial transition zone is present and that the most labile

654 components are likely consumed; but further study is required to confirm this

655 interpretation. However, we should note, that the majority of surface meltwater runoff

656 from the Greenland ice sheet is evacuated by large marine-terminating glaciers, as

657 opposed to land-terminating systems (Rignot and Kanagaratnam, 2006). Such systems

658 would export subglacially-routed meltwater and associated organic carbon directly to the

659 coastal ocean, thus circumventing any proglacial processing.

6. Conclusions

662

Glacial runoff draining the Greenland ice sheet exports a unique brand of organic

664 carbon, distinct from riverine organic carbon. Glacial organic carbon has low DOC

665 concentrations, higher POC concentrations, relatively low DOC/DON ratios ( $\sim 4-25)$ a 
terrestrial $\delta^{13} \mathrm{C}$ signature, is depleted in $\mathrm{DO} \Delta^{14} \mathrm{C}$, and is nitrogen-rich. Conversely,

667 riverine organic carbon though possessing a terrestrial $\delta^{13} \mathrm{C}$ signature, has high DOC

668 concentrations, a larger DOC/POC ratio, high DOC/DON ratios $(>30)$, is enriched in

$669 \mathrm{DO} \Delta^{14} \mathrm{C}$, and is nitrogen-rich (Hedges et al., 1997). Current organic carbon export from

670 the Greenland ice sheet is not insignificant, estimated to be equivalent to the DOC flux

671 from a small Arctic river and the POC flux from a major Arctic river. These fluxes will

672 only increase as surface melt on the ice sheet surface increases. Furthermore, the DOC

673 flux may disproportionally increase as the subglacial drainage system extends and

674 develops, perhaps resulting in a constant winter flux of more concentrated, basally-

675 derived DOC. Further study is needed in order to fully determine the mechanisms which

676 cause glacial organic carbon to be paradoxically radiocarbon depleted, yet also still retain

677 some labile components. Here we propose two potential mechanisms: (1) in situ

678 microbial activity utilizing radiocarbon depleted organic carbon stores, and thereby

679 producing ${ }^{14} \mathrm{C}$-depleted proteinaceous material, or (2) labile components of the original

680 overridden organic matter remain that have been preserved under the ice sheet.

681 Conceivably, both of these processes could be occurring simultaneously, with regions

682 populated by subglacial microbial communities accessed by the distributed drainage

683 system during low flow periods, and isolated organic carbon stores tapped by headward

684 progression of the subglacial drainage system at the peak summer meltseason.

686 Acknowledgements. This research was supported by: the WHOI Clark Arctic Research

687 Initiative (EBK, SBD, MAC), the National Science and Engineering Research Council of

688 Canada (MPB), the WHOI Climate Change Institute (MPB), and a Horton Hydrology

689 Grant from the American Geophysical Union (MPB). I am grateful to P. Henderson for

690 conducting the POC/PON and nutrient analyses, to M. Lafreniere and Steve Koziar for

691 assistance with the ion chromatography analyses, to M. Nieto-Cid and J. Becker for

692 assistance with the dissolved organic carbon analyses, to Ann McNichol and the

693 NOSAMS prep lab staff for assistance with the radiocarbon analyses, to D. Griffith and J.

694 Saenz for helpful conversations, to K. Longnecker for comments that improved the

695 manuscript, to M. Behn, I. Joughin, and K. Ponair for assistance in sampling the inland

696 ice, and to B. Gready, P. Henderson, A. Criscitiello, and M. Evans for their valuable

697 assistance in the field.

698 


\section{References}

700 Barker, J.D., Sharp, M.J., Fitzsimons, S.J., Turner, R.J., 2006. Abundance and dynamics

Bhatia, M., Sharp, M., Foght, J., 2006. Distinct bacterial communities exist beneath a high arctic polythermal glacier. Appl. Environ. Microbiol. 72, 5838-5845.

Carpenter, E.J., Lin, S.J., Capone, D.G., 2000. Bacterial activity in South Pole snow. Appl. Environ. Microbiol. 66, 4514-4517.

Cheng, S.M., Foght, J.M., 2007. Cultivation-independent and -dependent characterization of Bacteria resident beneath John Evans Glacier. FEMS Microbiol. Ecol. 59, 318330 .

Das, S.B., Joughin, I., Behn, M.D., Howat, I.M., King, M.A., Lizarralde, D., Bhatia, M.P., 2008. Fracture propagation to the base of the Greenland Ice Sheet during supraglacial lake drainage. Science 320, 778-781.

Dittmar, T., Kattner, G., 2003. The biogeochemistry of the river and shelf ecosystem of the Arctic Ocean: a review. Mar. Chem. 83, 103-120.

Druffel, E.R.M., Bauer, J.E., 2000. Radiocarbon distributions in Southern Ocean dissolved and particulate organic matter. Geophys. Res. Lett. 27, 1495-1498.

Dubnick, A., Barker, J., Sharp, M., Wadham, J., Lis, G., Telling, J., Fitzsimons, S., Jackson, M., 2010. Characterization of dissolved organic matter (DOM) from 
glacial environments using total fluorescence spectroscopy and parallel factor analysis. Ann. Glaciol. 51, 111-122.

Escher, A., 1971. Map Sheet no. 3 Sondre Stromfjord - Nugssu aq Geological Maps of Greenland 1:500,000. Geological Survey of Denmark and Greenland (GEUS), Copenhagen.

Hansell, D., 2002. in: Hansell, D., Carlson, C. (Eds.), Biogeochemistry of Marine Dissolved Organic Matter. Academic Press, New York.

Hedges, J.I., Clark, W.A., Quay, P.D., Richey, J.E., Devol, A.H., Santos, U.D., 1986. Compsitions and fluxes of particulate organic material in the amazon river Limnol. Oceanogr. 31, 717-738.

Hedges, J.I., Keil, R.G., Benner, R., 1997. What happens to terrestrial organic matter in the ocean? Org. Geochem. 27, 195-212.

Hodson, A., Anesio, A.M., Tranter, M., Fountain, A., Osborn, M., Priscu, J., LaybournParry, J., Sattler, B., 2008. Glacial ecosystems. Ecological Monographs 78, 41-67.

Hood, E., Berner, L., 2009. Effects of changing glacial coverage on the physical and biogeochemical properties of coastal streams in southeastern Alaska. J. Geophys. Res.-Biogeosci. 114.

Hood, E., Fellman, J., Spencer, R.G.M., Hernes, P.J., Edwards, R., D'Amore, D., Scott, D., 2009. Glaciers as a source of ancient and labile organic matter to the marine environment. Nature 462, 1044-U1100.

Hood, E., Scott, D., 2008. Riverine organic matter and nutrients in southeast Alaska affected by glacial coverage. Nat. Geosci. 1, 583-587.

Hunt, A.P., Parry, J.D., Hamilton-Taylor, J., 2000. Further evidence of elemental composition as an indicator of the bioavailability of humic substances to bacteria. Limnol. Oceanogr. 45, 237-241.

Kujawinski, E.B., Longnecker, K., Blough, N.V., Vecchio, R.D., Finlay, L., Kitner, J.B., Giovannoni, S.J., 2009. Identification of possible source markers in marine dissolved organic matter using ultrahigh resolution mass spectrometry. Geochim. Cosmochim. Acta 73, 4384-4399.

Lafreniere, M.J., Sharp, M.J., 2004. The concentration and fluorescence of dissolved organic carbon (DOC) in glacial and nonglacial catchments: Interpreting hydrological flow routing and DOC sources. Arct. Antarct. Alp. Res. 36, 156-165. 
McNichol, A.P., Aluwihare, L.I., 2007. The power of radiocarbon in biogeochemical studies of the marine carbon cycle: Insights from studies of dissolved and particulate organic carbon (DOC and POC). Chem. Rev. 107, 443-466.

Mernild, S.H., Liston, G.E., Hiemstra, C.A., Steffen, K., Hanna, E., Christensen, J.H., 2009. Greenland Ice Sheet surface mass-balance modelling and freshwater flux for 2007, and in a 1995-2007 perspective. Hydrol. Processes 23, 2470-2484.

Millot, R., Gaillardet, J., Dupre, B., Allegre, C.J., 2003. Northern latitude chemical weathering rates: clues from the Mackenzie River Basin, Canada. Geochim. Cosmochim. Acta 67, 1305-1329.

Pautler, B.G., Simpson, A.J., Simpson, M.J., Tseng, L.-H., Spraul, M., Dubnick, A., Sharp, M.J., Fitzsimons, S.J., 2011. Detection and Structural Identification of Dissolved Organic Matter in Antarctic Glacial Ice at Natural Abundance by SPRW5-WATERGATE (1)H NMR Spectroscopy. Environ. Sci. Technol. 45, 47104717.

Petsch, S.T., Eglinton, T.I., Edwards, K.J., 2001. C-14-dead living biomass: Evidence for microbial assimilation of ancient organic carbon during share weathering. Science $292,1127-1131$.

Raymond, P.A., Bauer, J.E., 2001a. Riverine export of aged terrestrial organic matter to the North Atlantic Ocean. Nature 409, 497-500.

Raymond, P.A., Bauer, J.E., 2001b. Use of $14 \mathrm{C}$ and $13 \mathrm{C}$ natural abundances for evaluating riverine, estuarine, and coastal DOC and POC sources and cycling: a review and synthesis. Org. Geochem. 32, 469-485.

Rignot, E., Kanagaratnam, P., 2006. Changes in the Velocity Structure of the Greenland Ice Sheet. Science 311, 986-990.

Sharp, M., Parkes, J., Cragg, B., Fairchild, I.J., Lamb, H., Tranter, M., 1999. Widespread bacterial populations at glacier beds and their relationship to rock weathering and carbon cycling. Geology 27, 107-110.

Shiklomanov, A., 2009. River Discharge, in: Richter-Menge, J., Peterson, T.C., Baringer, M.O. (Eds.), Arctic Report Card 2009. NOAA, pp. 28-29.

Skidmore, M., Anderson, S.P., Sharp, M., Foght, J., Lanoil, B.D., 2005. Comparison of microbial community compositions of two subglacial environments reveals a possible role for microbes in chemical weathering processes. Appl. Environ. Microbiol. 71, 6986-6997. 
828 Skidmore, M., Tranter, M., Tulaczyk, S., Lanoil, B., 2010. Hydrochemistry of ice stream beds - evaporitic or microbial effects? Hydrol. Processes 24, 517-523.

Skidmore, M.L., Foght, J.M., Sharp, M.J., 2000. Microbial life beneath a high Arctic glacier. Appl. Environ. Microbiol. 66, 3214-3220.

Tranter, M., 2003. Geochemical Weathering in Glacial and Proglacial Environments, in: Drever, J.I. (Ed.). Elsevier, pp. p.189-205.

Tranter, M., Sharp, M.J., Lamb, H.R., Brown, G.H., Hubbard, B.P., Willis, I.C., 2002. Geochemical weathering at the bed of Haut Glacier d'Arolla, Switzerland - a new model. Hydrol. Processes 16, 959-993.

Wadham, J.L., Tranter, M., Hodson, A.J., Hodgkins, R., Bottrell, S., Cooper, R., Raiswell, R., 2010a. Hydro-biogeochemical coupling beneath a large polythermal Arctic glacier: Implications for subice sheet biogeochemistry. Journal of Geophysical Research-Earth Surface 115.

Wadham, J.L., Tranter, M., Skidmore, M., Hodson, A.J., Priscu, J., Lyons, W.B., Sharp, M., Wynn, P., Jackson, M., 2010b. Biogeochemical weathering under ice: Size matters. Global Biogeochem. Cycles 24.

Wadham, J.L., Tranter, M., Tulaczyk, S., Sharp, M., 2008. Subglacial methanogenesis: A potential climatic amplifier? Global Biogeochem. Cycles 22. 
Table 1. Average percent ionic contributions (rounded to whole percent) from major dissolved anions and cations in the 'N' glacier outflow waters in Early May (May 18 to 24), Late May (May 25 to 31) and July (July 10 to 16). Errors represent standard

859 deviation from the mean value. Mean values exclude the May 21 outlier sample, whose

860 percent ionic contributions and absolute concentrations in $\mu \mathrm{M}$ (in parentheses) are shown 861 in the last row.

862

\begin{tabular}{|l|l|l|l|l|l|l|l|l|}
\hline Time & ${ }^{*} \mathbf{C a}^{2+}$ & $* \mathbf{M g}^{2+}$ & $* \mathbf{N a}^{+}$ & ${ }^{*} \mathbf{K}^{+}$ & ${ }^{2} \mathbf{S O}_{4}{ }^{2-}$ & $\mathbf{N O}_{3}{ }^{-}$ & $\mathbf{C l}^{-}$ & $\mathbf{H C O}_{3}{ }^{-}$ \\
\hline Early May & $21 \pm 1$ & $14 \pm 0$ & $8 \pm 1$ & $6 \pm 1$ & $21 \pm 4$ & $1 \pm 0$ & $2 \pm 0$ & $28 \pm 4$ \\
\hline Late May & $16 \pm 2$ & $13 \pm 0$ & $10 \pm 2$ & $10 \pm 1$ & $10 \pm 3$ & $0 \pm 0$ & $2 \pm 0$ & $39 \pm 3$ \\
\hline July & $17 \pm 1$ & $13 \pm 1$ & $8 \pm 1$ & $11 \pm 1$ & $5 \pm 1$ & $0 \pm 0$ & $2 \pm 1$ & $45 \pm 1$ \\
\hline May 21 outlier & $28(666)$ & $15(357)$ & $3(60.4)$ & $3(77.4)$ & $39(929)$ & $2(38.7)$ & $1(29.4)$ & $8(196)$ \\
\hline
\end{tabular}

864 Table 2. Mean DOC and POC concentrations ( $\mathrm{mg} / \mathrm{L})$ in supraglacial, subglacial, and 865 proglacial samples collected in 'Early May' (May 18-24), 'Late May (May 25-June 1), 866 and 'July' (July 10-16). The 'Early May' average does not include the concentrated May 86721 outlier sample $([\mathrm{DOC}]=4.1 \mathrm{mg} / \mathrm{L},[\mathrm{POC}]=13.2 \mathrm{mg} / \mathrm{L})$. The notation '--' indicates no 868 measurement was taken.

869

870

\begin{tabular}{|c|c|c|c|c|c|c|c|c|c|}
\hline Sample Type & \multicolumn{3}{|c|}{ 'Early May' } & \multicolumn{3}{c|}{ 'Late May' } & \multicolumn{3}{c|}{ 'July' } \\
\hline & $\mathbf{n}$ & DOC & POC & n & DOC & POC & n & DOC & POC \\
\hline Supraglacial & 1 & 0.2 & 0.30 & 1 & 0.2 & 0.57 & 0 & -- & -- \\
\hline 'N' Glacier Outflow & 7 & $0.6 \pm 0.1$ & $3.4 \pm 1.0$ & 10 & $0.4 \pm 0.1$ & $3.6 \pm 1.3$ & 12 & $0.3 \pm 0.2$ & $3.5 \pm 1.1$ \\
\hline 'M' Glacier Outflow & 1 & 0.8 & 2.8 & 1 & 1.2 & 3.9 & 1 & 0.2 & 2.2 \\
\hline 'O' Glacier Floodplain & 1 & 1.7 & 0.76 & 0 & -- & -- & 0 & -- & -- \\
\hline Proglacial Lake & 1 & 7.4 & 1.0 & 1 & 0.7 & 1.7 & 1 & 0.4 & -- \\
\hline Lake Outflow & 1 & 2.7 & 0.5 & 0 & -- & -- & 0 & -- & -- \\
\hline May 21 outlier & 1 & 4.1 & 13.23 & -- & -- & -- & -- & -- & -- \\
\hline
\end{tabular}




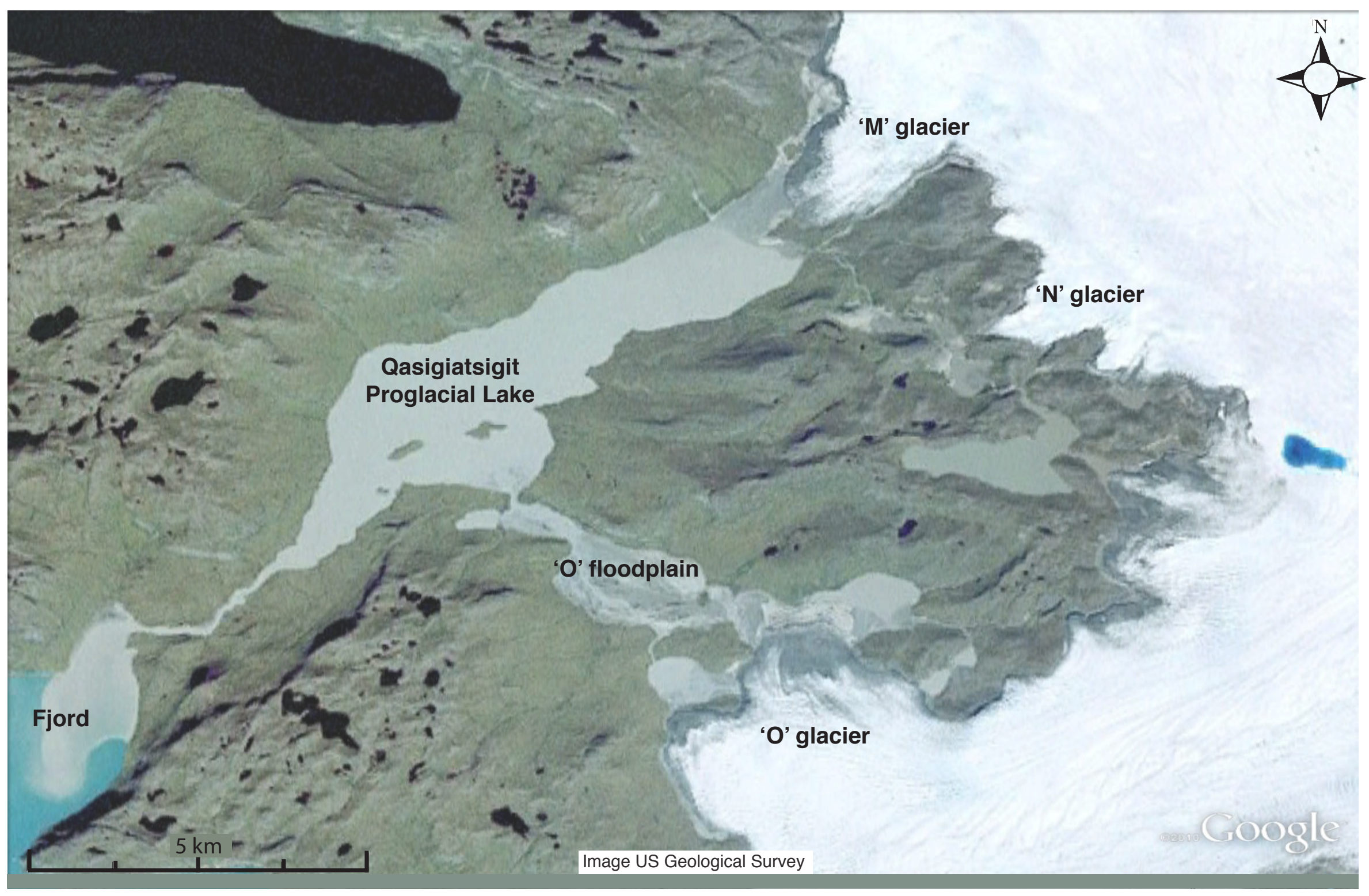

Figure 1. Map of field site on the southwestern margin of the Greenland ice sheet. 


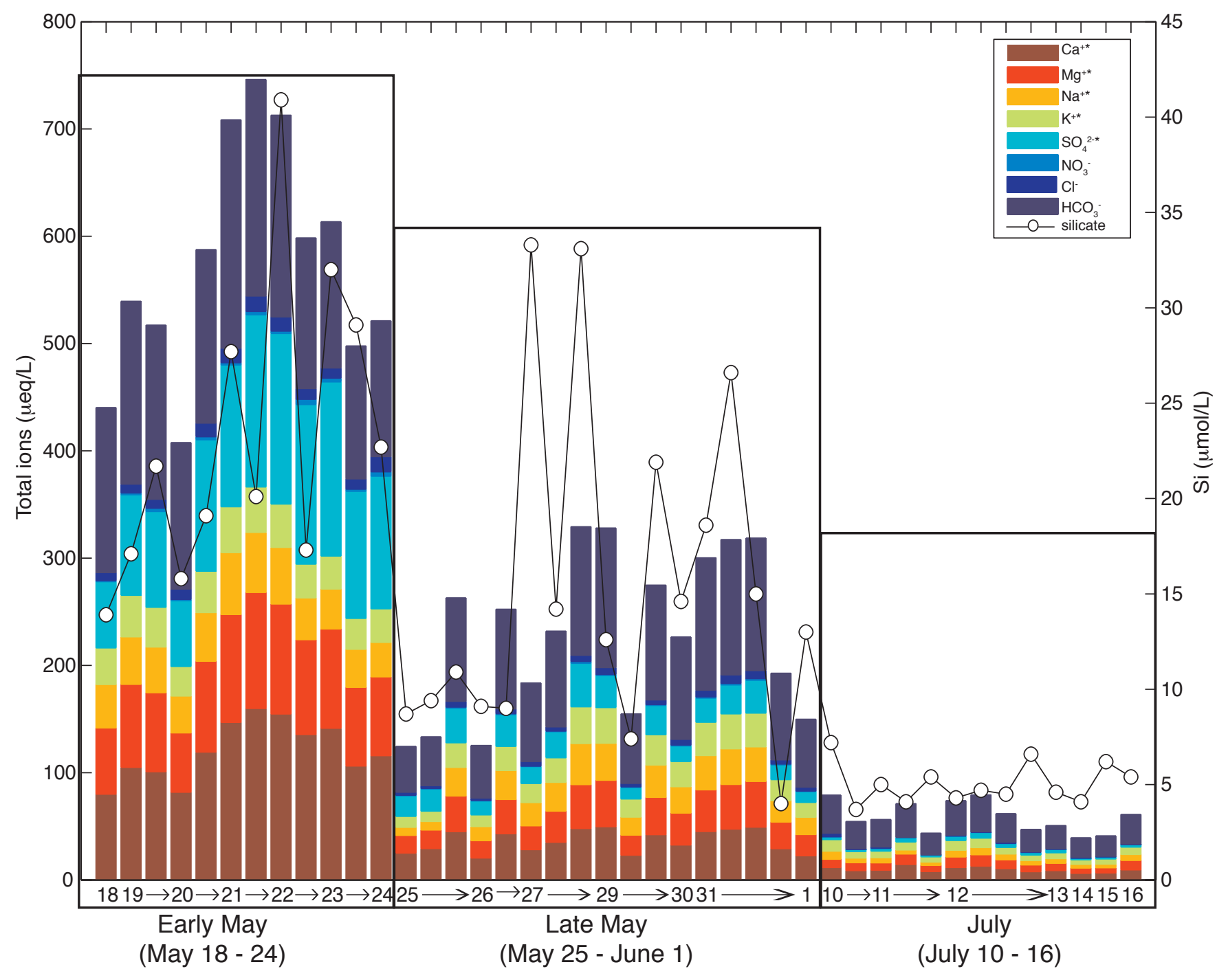

Figure 2. Total ionic concentrations of major dissolved anions and cations (left y-axis) and dissolved silicate (right y-axis) in the $\mathrm{N}$ glacier outflow waters from May 18 to July 16, 2008. The (*) indicates crustal contributions (see text for details). 


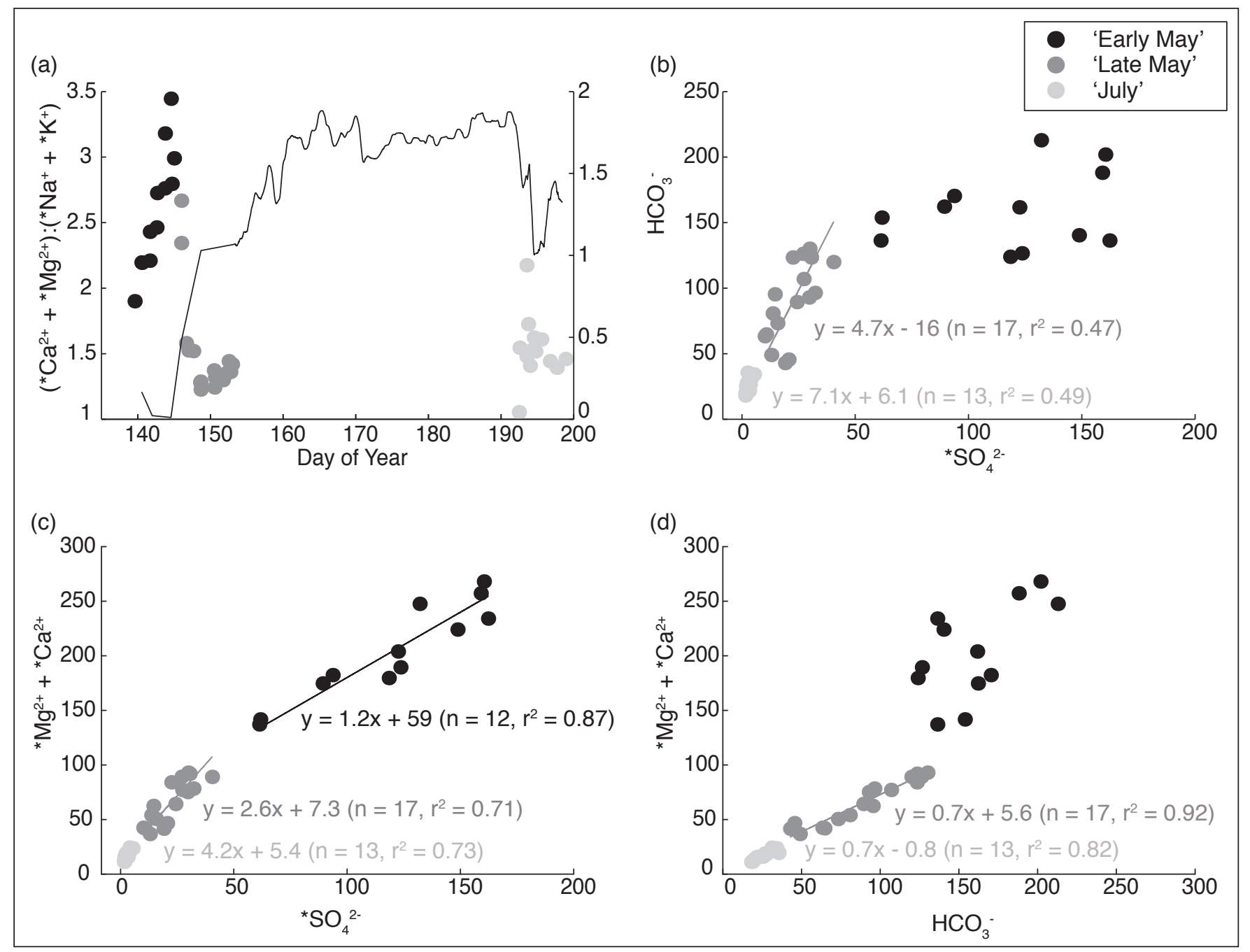

Figure 3. (a) Ratio of monovalent to divalent crustal cations, (b) linear regressions (Model II, geometric mean) between $\mathrm{HCO} 3$ - and *SO42-, (c) linear regressions (Model II, geometric mean) between $(* \mathrm{Mg} 2++* \mathrm{Ca} 2+)$ and $* \mathrm{SO} 42-$ and (d) HCO3- for the 'N' glacier runoff in the 'Early May' (May 18-24), 'Late May' (May 25-June 1) and 'July' (July 10-16) time periods. In (a) measured discharge at ' $N$ ' glacier is shown on the right y-axis. All regressions presented are significant to the $99 \%$ confidence levels. Associations not shown did not meet this criterion. The Early May (May 21) outlier sample was excluded. 

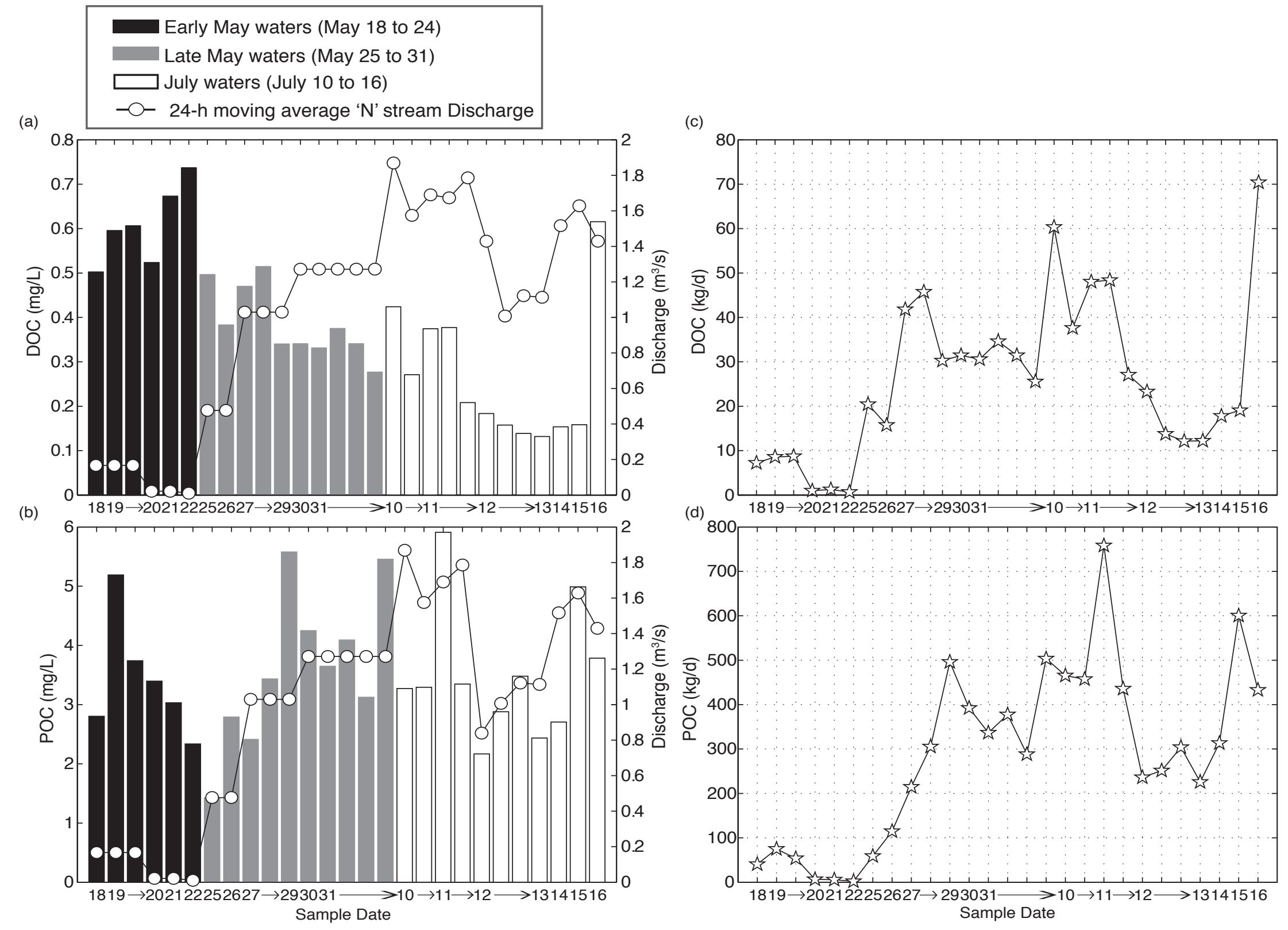

Figure 4. (a) DOC and (b) POC concentrations in point samples collected from the ' $N$ ' glacier outflow in May and July 2008, with the discharge measured at the time closest to that of the sample collection time shown on the right y-axis. In May the discharge data is limited to point measurements. The daily DOC and POC flux are shown in (c) and (d). 


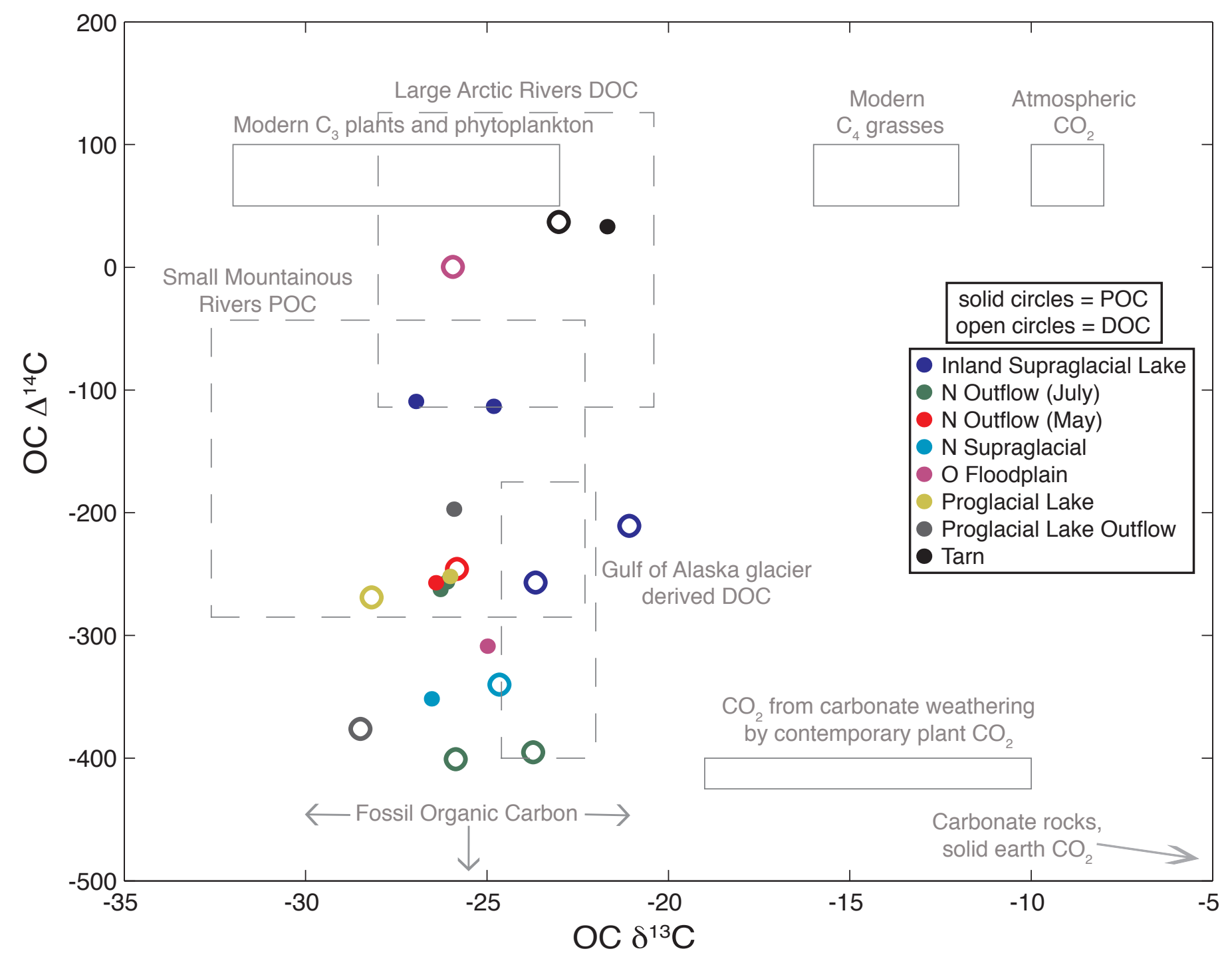

Figure 5. Dissolved and particulate organic $\Delta 14 \mathrm{C}$ and $\delta 13 \mathrm{C}$ in glacial and proglacial samples collected on the western margin of the Greenland ice sheet. Solid grey boxes illustrate isotopic ranges of endmember carbon sources (Mayorga et al., 2005), whereas dashed grey boxes illustrate literature values for large Arctic rivers DOC (Raymond et al., 2007), small mountainous rivers POC (Raymond and Bauer, 2001), and Gulf of Alaska (GOA) glacially-derived DOC (Hood et al., 2009). The fossil organic carbon source is radiocarbon dead $(\Delta 14 \mathrm{C} \leq-1000 \%)$, and can have $\delta 13 \mathrm{C}$ values ranging from $-15 \%$ o to $-35 \%$. 


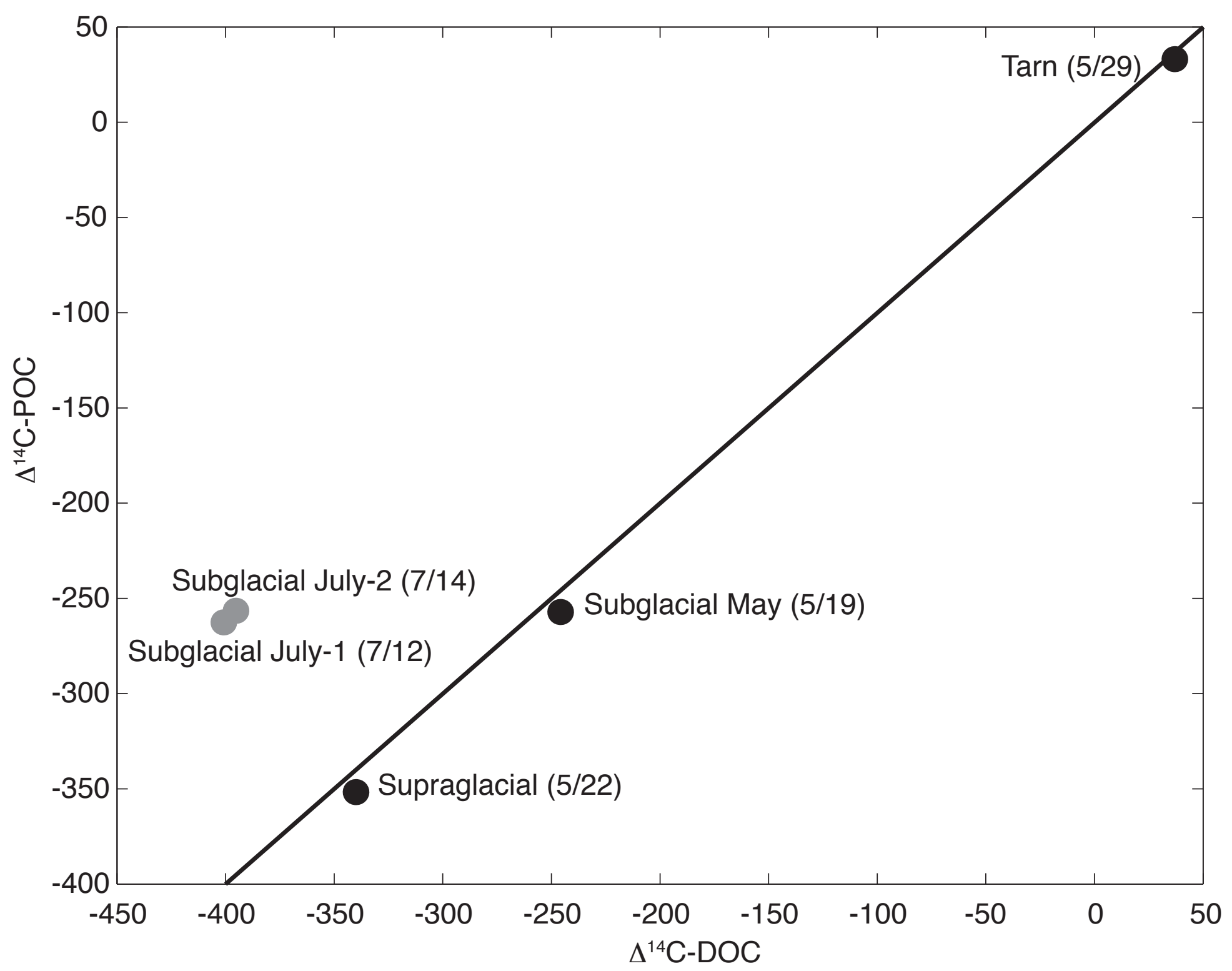

Figure 6. Dissolved and particulate organic radiocarbon in the ' $N$ ' glacier outflow samples collected in May and July as well as end-member samples from ' $\mathrm{N}$ ' supraglacial water and a proglacial tarn. For clarity, dates of collection (in 2008) and a 1:1 line (black) are also shown. 


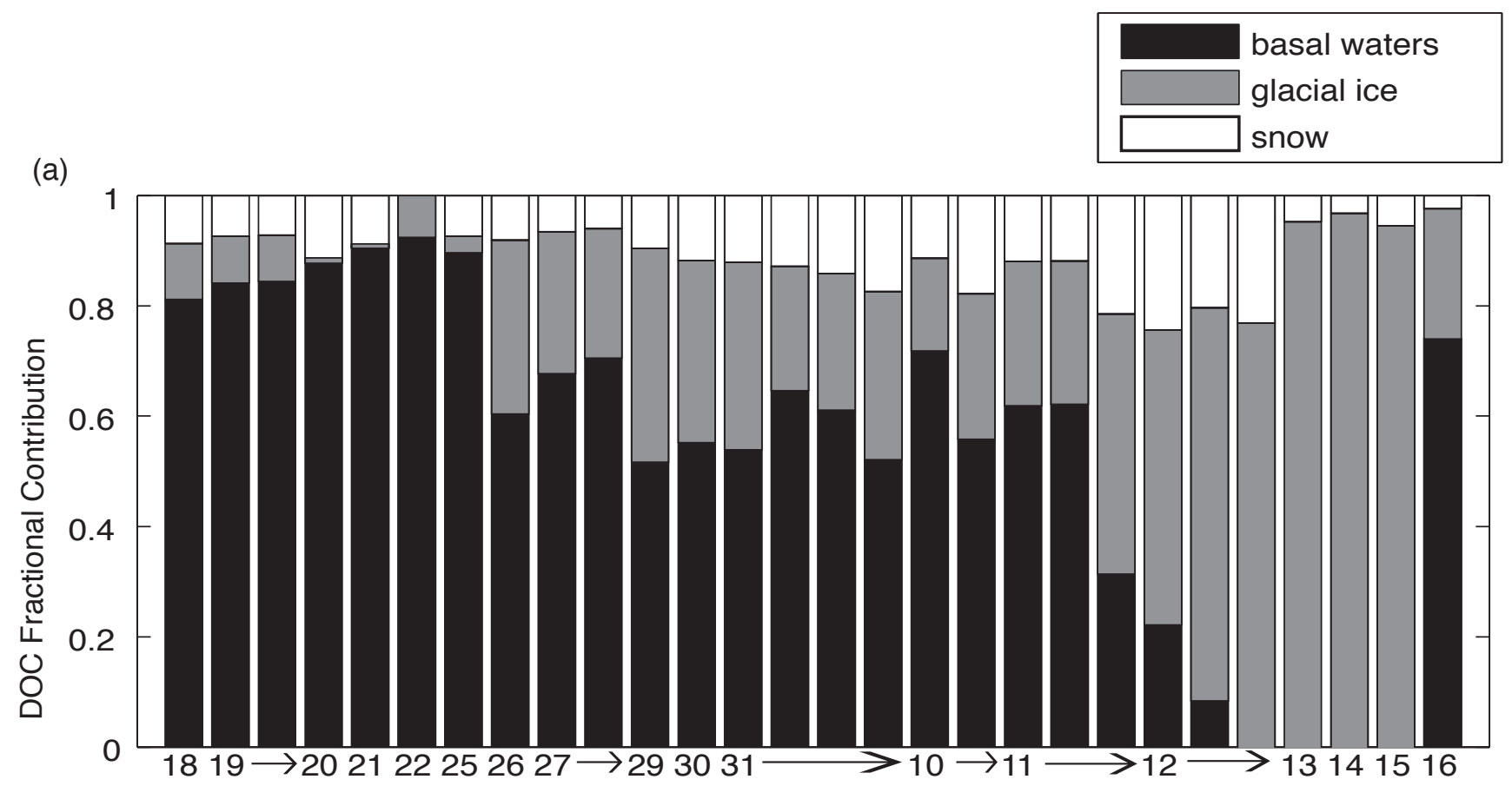

(b)

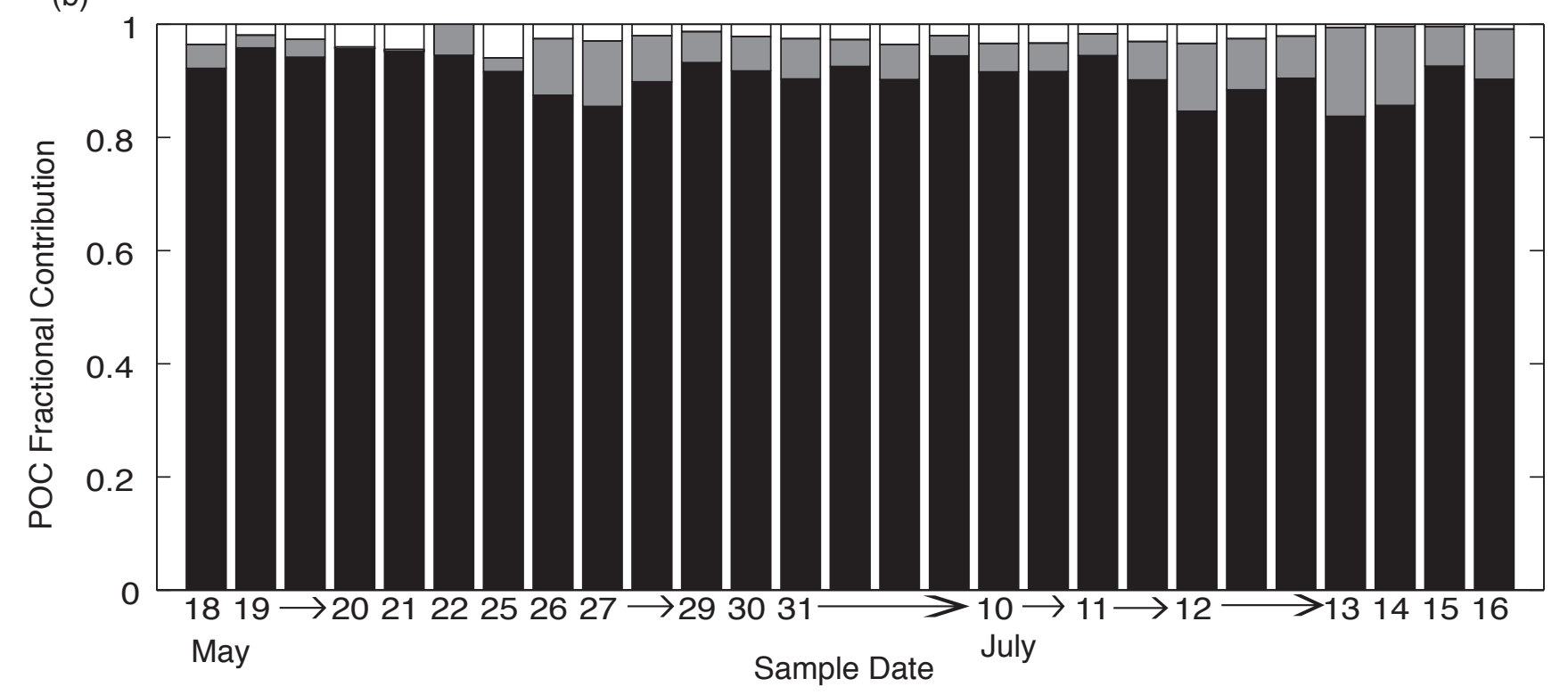

Figure 7. Estimates of proportional contributions from the basal waters, glacial ice, and snow end-member pools to the total runoff DOC and POC. 

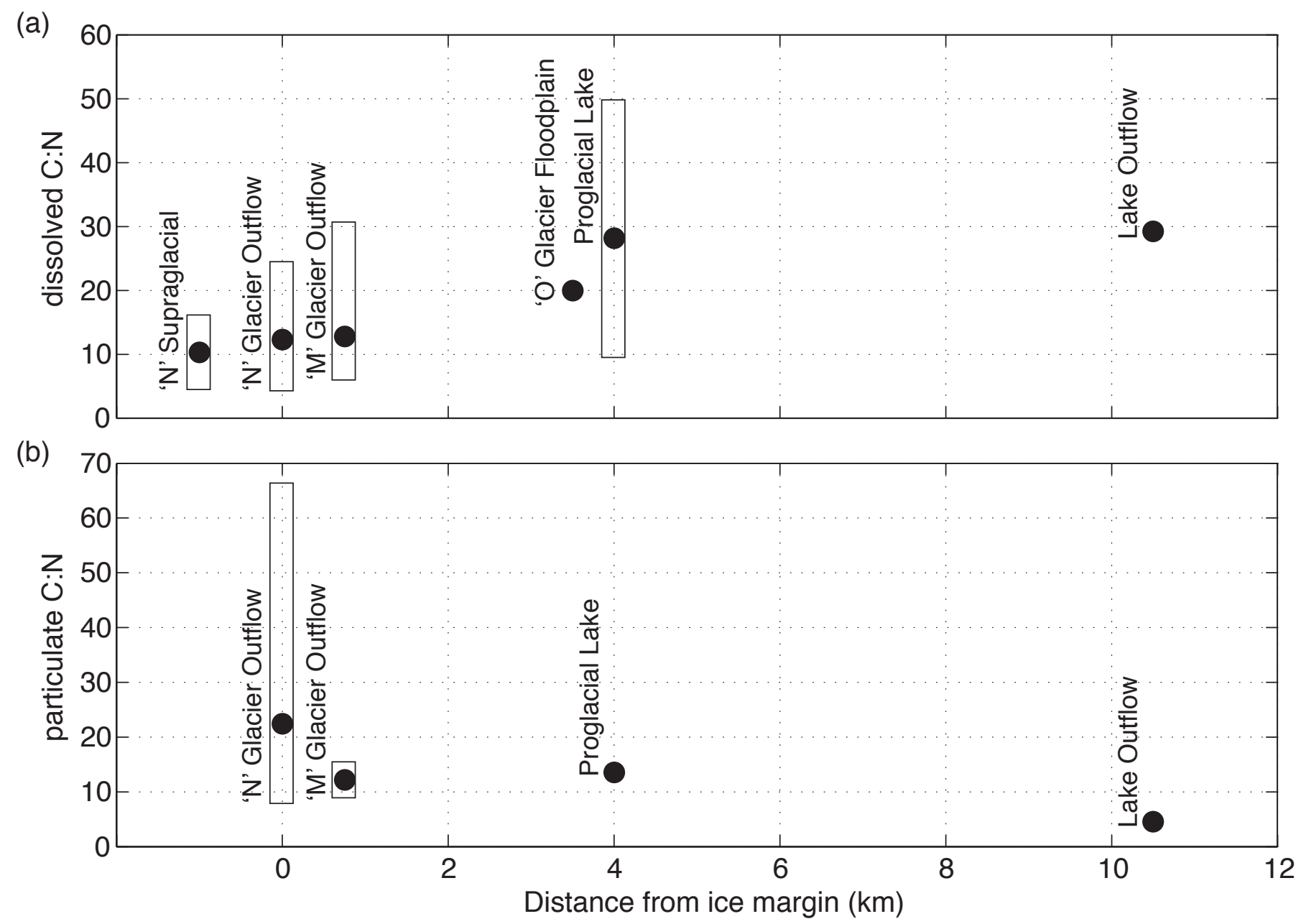

Figure 8. (a) Mean dissolved C: $N$ ratios of ' $N$ ' supraglacial ice $(n=2)$, ' $N$ ' glacier outflow $(n=26)$, 'M' glacier floodplain ( $\mathrm{n}=4)$, 'O' glacier floodplain $(\mathrm{n}=1)$, proglacial lake $(\mathrm{n}=3)$, and lake outflow $(\mathrm{n}=1)$. (b) Mean particulate C:N ratios of the ' $\mathrm{N}$ ' glacier outflow $(\mathrm{n}=18)$, 'M' glacier floodplain $(\mathrm{n}=2)$, proglacial lake $(\mathrm{n}=1)$, and lake outflow $(\mathrm{n}=1)$ samples. Particulate $\mathrm{C}: \mathrm{N}$ ratios for the ' $\mathrm{N}$ ' supraglacial and ' $\mathrm{O}$ ' glacier floodplain were below detection. Observed ranges for both the dissolved and particulate $\mathrm{C}: \mathrm{N}$ ratios are shown by the rectangles. 


\title{
Chapter 5
}

Iron export from the Greenland ice sheet

\begin{abstract}
Here we report dissolved $(<0.2 \mu \mathrm{m})$ and suspended sediment particulate $(>0.7 \mu \mathrm{m}) \mathrm{Fe}$ concentrations in glacial meltwater runoff from the southwest margin of the Greenland ice sheet and across the surrounding proglacial region. Seasonal variability was evident in both the dissolved and particulate Fe fractions, and is likely tied to the seasonal evolution of the subglacial drainage system. Two sequential leaches were used to dissolve the particulate (oxyhydr)oxide $\mathrm{Fe}$, and on average, a large fraction $(50 \%)$ of the particulate $\mathrm{Fe}$ in glacial runoff was labile. We report average discharge-weighted dissolved $(\mathrm{dFe})$ and labile particulate $\left(\mathrm{pFe}_{1}\right)$ Fe concentrations of $3.7 \mu \mathrm{M}$ and $94.6 \mu \mathrm{M}$, respectively. Using these concentrations, we estimate an annual dFe flux from the Greenland ice sheet of $\sim 1.5 \times 10^{9}$ moles/year $(0.01 \mathrm{Tg} / \mathrm{y})$, and annual $\mathrm{pFe} \mathrm{e}_{1}$ of $3.6 \times 10^{10}$ moles/year $(0.20$ $\mathrm{Tg} / \mathrm{y})$. Correcting for estuarine removal $(90 \%)$, this yields a combined dissolved and labile particulate flux of $\sim 3.8 \times 10^{9}$ moles/year $(0.21 \mathrm{Tg} / \mathrm{y})$. This flux estimate is of the same order of magnitude of the annual soluble Fe dust flux to the North Atlantic Ocean; thus, glacial meltwater runoff from the Greenland ice sheet may provide labile Fe capable of fueling primary productivity to downstream high latitude marine ecosystems during the summer meltseason.
\end{abstract}




\section{Introduction}

Glacial runoff from the Greenland and Antarctic ice sheets provides a significant annual freshwater input to high latitude oceans, capable of delivering associated sediment, carbon and trace metals to coastal ecosystems (Bhatia et al., in prep; Raiswell et al., 2006; Statham et al., 2008). Primary productivity in large regions of the oceans is believed to be limited by a deficiency of biologically obligate micronutrients, such as iron (Fe) (e.g. Moore et al., 2001). The Southern Ocean is one of the most prominent examples of Fe limitation on phytoplankton primary production (Martin, 1990; Martin et al., 1990). Although Fe is not considered to be principally limiting in the North Atlantic or Arctic Ocean waters surrounding the Greenland ice sheet (GrIS) (Martin et al., 1993), previous work suggests that it may be a co-limiting nutrient in the northeast Atlantic (Blain et al., 2004; Mills et al., 2004). Other work suggests that aeolian Fe supply may limit the maximum potential of primary productivity in the North Atlantic at particular times of the year, such as during or after the spring phytoplankton bloom period (Moore et al., 2006; Nielsdottir et al., 2009). Recently, studies have illustrated that sediment at the base of calved ice-bergs (Raiswell et al., 2008; Raiswell et al., 2006) or associated with glacial runoff (Statham et al., 2008), and glacially-derived dust (Crusius et al., 2011) can supply bioavailable Fe to the coastal and open ocean, potentially fueling primary productivity at high latitudes. In Greenland, peak glacial runoff occurs at the height of the summer melt-season when primary production is limited by a depletion of upwelled nutrients in the preceding months during the spring bloom. Thus, glacial discharge from the Greenland ice sheet may annually supply critical Fe at a time when solar radiation is at its maximum, sustaining primary production during the summer (Statham et al., 2008). The supply of such glacially-sourced Fe may also be expected to increase as climatic warming intensifies melting of the GrIS.

The majority of meltwater discharged from the Greenland ice sheet first drains from the surface (supraglacial) to the ice sheet bed (subglacial), where it can interact with the basal sediment and bedrock material on various timescales before exiting at the base 
of land- and marine-terminating outlet glaciers (Bartholomew et al., 2010; Das et al., 2008). Mechanical and chemical weathering beneath glaciers may produce nanoparticulate iron (oxyhydr)oxides from reactive iron-bearing phases (e.g. sulfides, carbonates, olivines, and pyroxenes) (Raiswell et al., 2006). Furthermore, subglacial microbial activity may yield secondary Fe minerals that are more labile than the original silicate rock matrix, and thus supply dissolved Fe to the runoff waters (Statham et al., 2008). Finally, the presence of organic carbon and anoxic regions at the bed may serve to maintain a portion of the comminuted Fe in solution. In this study we present dissolved $(<0.2 \mu \mathrm{m})$ and particulate $(>0.7 \mu \mathrm{m})$ Fe concentrations in glacial runoff draining the GrIS, as well as from the surrounding proglacial region. Our study site is typical of many land-terminating regions along the western margin of the ice sheet, in that there are several outlet glaciers whose runoff collects in a single large proglacial lake that then empties into a fjord. Thus, the effects of proglacial processing on the ultimate magnitude and type of glacial Fe exported is likely typical of other land-terminating Greenland glacial systems.

\section{Methods}

\subsection{Field Site Description}

The primary sampling region for this study was a three land-terminating outlet glaciers on the southwestern margin of the Greenland ice sheet $\left(\sim 68^{\circ} 02^{\prime} 34^{\prime \prime} \mathrm{N}\right.$, $50^{\circ} 16^{\prime} 08^{\prime \prime} \mathrm{W}$ ), approximately $125-\mathrm{km}$ south of Jakobshavn Isbrae (Figure 1). This region is underlain by quartz diorite rocks of the Nagssugtqidian Orogenic Complex (K/Ar age: 1790-1650 m.y.) (Escher, 1971). Runoff from the three outlet glaciers (named here, 'M', 'N', and ' $\mathrm{O}$ ') drained into a large $\left(\sim 24 \mathrm{~km}^{2}\right)$ proglacial lake (Qasigiatsigit lake) before emptying into a fjord. The proglacial lake was ice-covered at the beginning of our sampling period in May and was ice-free in July. Sampling was conducted during a 2week period in May (18 to 31) and 1-week period in July (10 to 16) 2008. A higher resolution time-series of daily and sub-daily samples was taken at the 'N' glacier outflow, 
and point samples were collected from the ' $\mathrm{M}$ ' glacier outflow, ' $\mathrm{O}$ ' glacier floodplain ( $4.5 \mathrm{~km}$ downstream of stream outflow mouth), a stream (named 'Waterfall stream') draining the marginal ice area between ' $\mathrm{N}$ ' and ' $\mathrm{O}$ ' glaciers, the proglacial lake, and the lake outflow to the fjord. The outflow streams draining the ' $\mathrm{N}$ ', 'M', and 'O' glaciers were all subglacially routed, exiting at the base of the glaciers. However, our field inspection of the 'Waterfall stream' did not reveal a subglacial water source, indicating that this stream may primarily consist of supraglacial marginal melt; this hypothesis is bolstered by the low electrical conductivity $\left(4.6 \mu \mathrm{S} / \mathrm{cm}^{3}\right)$ of this sample (Table 1). Endmember samples were also collected from a meltwater pond on the surface of ' $N$ ' glacier ('Supraglacial'), and from groundwater at the ' $M$ ' glacier floodplain and the bank of ' $N$ ' glacier. Groundwater samples were taken using a stainless steel piezometer. Additional end-member samples from a fjord were collected from a secondary sampling region $\left(\sim 68^{\circ} 55^{\prime} 70^{\prime \prime} \mathrm{N}, 50^{\circ} 17^{\prime} 84^{\prime \prime} \mathrm{W}\right)$ along the western margin of the ice sheet, approximately $100-\mathrm{km}$ north of our primary sampling region. At this site, one sample was taken near the shore at the confluence of a glacial marginal runoff stream and the fjord water (named "glacial runoff in fjord", and a second sample was taken offshore, with no visible glacial meltwater inputs (named "fjord water"). Both samples were taken at the surface.

Discharge measurements from ' $N$ ' glacier are reported in a previous study where we described the hydrology and subglacial drainage system evolution (Bhatia et al., 2011). Briefly, the subglacial drainage system beneath ' $N$ ' glacier seasonally evolves from a distributed system in early May where a large proportion ( $\geq 49 \%$ ) of the runoff is from delayed flow waters stored at the bed, to a channelized drainage system in late May (12-36\% delayed flow contribution) and July (5-17\% delayed flow contribution), in which the runoff is comprised of increasing amounts of dilute ice-melt with limited basal contact (Bhatia et al., 2011). In the present study, discharge was also measured at the 'Waterfall Stream'. The size of the catchment of the 'Waterfall stream' was estimated using the total measured discharge $\left(\mathrm{m}^{3} / 46\right.$ days) and the range of estimated melt-rates over this period at ' $\mathrm{N}$ ' glacier $\left(2.09-0.9 \mathrm{~m} / 46\right.$ days), where discharge ( $\mathrm{m}^{3} / 46$ days) is equal to area $\left(\mathrm{m}^{2}\right) \times$ melt-rate $(\mathrm{m} / \mathrm{y})$ (Bhatia et al., 2011). The range of estimated melt- 
rates at ' $\mathrm{N}$ ' glacier was determined as the product of the discharge at ' $N$ ' glacier and range of potential catchment areas using the catchment delineation method described in Bhatia et al. (2011). Using this same method we were able to determine a reasonable range of catchment areas for ' $M$ ' glacier, which we combined with the melt-rate from ' $N$ ' glacier ( $1.28 \mathrm{~m} / 46$ days) associated with our best catchment area estimate for ' $\mathrm{N}$ ' glacier $\left(5 \mathrm{~km}^{2}\right)$ to determine potential discharge from ' $\mathrm{M}$ ' glacier.

\subsection{Sample Collection}

All LDPE plastic-ware used in trace Fe sample collection and analysis was cleaned using the following procedure: MilliQ rinse followed by a 5 -day soak in $0.1 \%$ citronox, 7x rinse with MilliQ, 5-day soak in 10\% trace metal grade HCL, and a final 3x MilliQ rinse.

Samples were collected for both dissolved and particulate Fe analyses. For the dissolved samples, glacial meltwater was collected directly from the streams/ponds using new 60 -mL plastic syringes. Sample water was filtered through $0.2 \mu \mathrm{m}$ Sterivex filters (Millipore). Filters were rinsed with a full syringe volume prior to sample collection. Filtered samples were stored in trace metal clean 20-mL LDPE bottles spiked with 40 $\mu \mathrm{L}$ of $8 \mathrm{~N}$ Optima trace metal grade nitric acid at room temperature until analysis. Particulate samples were collected on a pre-weighed, combusted $0.7 \mu \mathrm{m}$ glass fiber filters (GFF) using a combusted glass filtration apparatus. The volume of runoff filtered through each GFF filter, and the after-filtration weight (filter + suspended sediment) was also recorded. A GFF filter was used because these samples were originally collected for particulate organic carbon analyses. However, the observed particulate Fe concentrations were substantially higher than a filter process blank (see below) such that we were able to utilize these samples for Fe analyses.

\subsection{Leachable particulate Fe}

The concentrations of the Fe (oxyhydr)oxides in the suspended sediments on a weighed fraction of the $0.7 \mu \mathrm{m}$ GFF filter (particulate Fe) were determined using the 
117 selective dissolution protocol described Charette et al. (2005), which was adopted from

118 Hall et al. (1996). The only modification made to the protocol described in Charette et al.

119 (2005) was that the leach and sediments were centrifuged post-leach in HDPE centrifuge

120 tubes to ensure no sediment contamination during liquid sampling. Following Charette et

121 al. (2005), we used the L3 leach (0.25M hydroxlyamine hydrochloride $0.05 \mathrm{M} \mathrm{HCl}$ acid)

122 to extract "amorphous (oxy)hydroxides of iron", followed by the L4 leach (1M

123 hydroxylamine in $25 \%$ acetic acid) on the same filter fraction to extract "crystalline Fe

124 (hydr)oxides". In this study, we define the Fe released from the L3 leach as "labile Fe",

125 the Fe from the L4 leach as "crystalline Fe", and the Fe released from the sum of the L3

126 and L4 leaches as "total (oxyhydr)oxides". The caveats cited by Charette et al. (2005)

127 regarding the difficulty in quantifying the specific Fe fractions dissolved by each leach

128 are applicable here. Thus, the type of Fe extracted in different dissolution leaches is likely

129 quite broad and the results are method-dependent. To constrain our results, we also

130 extracted the Fe from a marine sediment reference standard (MESS-3, National Research

131 Council of Canada) using the L3 and L4 leaches. Among four replicates, our total \%

132 recovery for the MESS-3 standard ranged between 62-69\% after the L4 leach. Aliquots of

133 the L3 and L4 samples were diluted with 5\% optima grade nitric acid ( 1:20 to 1:600)

134 prior to Fe concentration analyses.

135

136

137

138

139

140

141

142

143

144

145

\subsection{Dissolved and leachate particulate Fe ICP-MS analysis and blank} corrections

Samples were measured for dissolved and particulate Fe using a Thermo-Electron Element 2 high-resolution single collector inductively coupled plasma mass spectrometry (ICP-MS) (Woods Hole Oceanographic Institution Plasma Mass Spectrometry facility), run in medium-resolution mode for ${ }^{56} \mathrm{Fe}$. All solution preparations and standard/sample/blank dilutions for ICP-MS analysis were performed in a class 100 trace-metal clean laboratory. Aliquots of the dissolved and particulate samples were diluted and spiked with an internal standard solution (5\% optima grade nitric acid, $3 \mathrm{ppb}$ $\left.{ }^{115} \mathrm{In}\right)$. The same standard solution was used for all samples, blanks and standards. To 
146 correct for instrument drift, the ${ }^{56} \mathrm{Fe}$ count rate was normalized to $\operatorname{In}^{115}$ and the instrument 147 response was quantified using a standard curve that matched the sample concentration 148 range. Fe standards were prepared from a stock solution created from a certified 1000149 ppm reference standard (Specpure, AlfaAeser). The Fe signal was corrected for the mean 150 blank count rate. Final Fe concentrations for the dissolved samples were a product of the measured concentration from the ICP-MS analysis $(\mathrm{g} / \mathrm{g})$ and the dilution factor, and are reported in $\mu \mathrm{M}$. Final Fe concentrations for the labile and crystalline Fe fractions were a product of the ICP-MS concentration $(\mathrm{g} / \mathrm{g})$, the dilution factor, and the weight of the L3/L4 solution divided by the proportion each analyzed filter fraction represented of the whole filter. The volume of water filtered through each GFF was then used to report the final particulate concentrations in $\mu \mathrm{M}$. It should be noted that this approach of scaling the filter fraction ICP-MS concentration up to the whole filter assumes an even distribution of sediment across the filter.

Sample concentrations were corrected for possible blank contributions from materials and filters by measuring process blanks. For the dissolved samples, the average Fe concentration of two MilliQ-water samples $(0.0155 \mu \mathrm{M})$ processed in the laboratory analogously to the field samples was subtracted from the final measured sample Fe concentrations. Three additional process blanks were processed in the laboratory by filtering MilliQ-water with syringes and Sterivex filters similar to those used in the field. However, the Fe concentrations in these laboratory process blanks were extremely low, less than the mean $\mathrm{HNO}_{3}-\mathrm{In}^{115}$ blank run on the ICP-MS. For the particulate samples, fractions of six pre-weighed, combusted GFF's prepared identically to those utilized for the samples were processed using the sequential L3 and L4 leaches. The average total GFF L3/L4 leach blank (L3: $5.06 \times 10^{-6} \mathrm{~g}$; L4: $1.31 \times 10^{-5} \mathrm{~g}$ ) was then multiplied by the sample filter fraction and subtracted from the measured Fe concentration of the filter fraction for each leach. Generally, the GFF leach blanks were low relative to the amount of Fe from the sample, approximately $1.7 \%$ on average of the total (oxyhydr)oxide Fe for both the L3 and L4 leach procedures. 


\section{Results}

The dissolved and particulate Fe concentrations for the end-member samples (supraglacial ice, groundwater), glacial runoff samples ('N', 'M', and 'O' glacier streams, Waterfall stream), proglacial samples (Proglacial lake, Lake outflow), and fjord samples are shown in Figure 1. The corresponding ranges of dissolved and particulate Fe concentrations are shown in Table 1. The highest dissolved $\mathrm{Fe}(\mathrm{dFe})$ concentrations were observed in groundwater collected along the bank of ' $N$ ' glacier outflow stream (1.65 $431 \mu \mathrm{M})$. However, the range of concentrations within the groundwater collected was variable, as a sample collected from the 'M' glacier floodplain was quite low in $\mathrm{dFe}(0.3$ $\mu \mathrm{M})$. The dFe concentrations from the mouth of ' $\mathrm{N}$ ' (mean =3.7 $\mu \mathrm{M})$ and ' $\mathrm{M}$ ' $(3.8 \mu \mathrm{M})$ glaciers were similar, and much larger than the dFe concentration in the supraglacial ice $(0.11 \mu \mathrm{M})$ and in the Waterfall Stream $(0.19 \mu \mathrm{M})$. The range of $\mathrm{dFe}$ concentrations observed in the ' $\mathrm{N}$ ' glacier runoff, where we had a greater seasonal coverage, encapsulated the range found in the ' $\mathrm{M}$ ' glacier runoff. In the proglacial area the $\mathrm{dFe}$ concentrations steadily increased along a transect from the ice margin ' $M$ ' glacier to the proglacial lake outflow in May (Figure 2). However, it is important to emphasize that this trend was limited to our observations along a single transect from ' $\mathrm{M}$ ' glacier to the lake outflow. Indeed, the highest $\mathrm{dFe}$ concentration measured in the ' $\mathrm{N}$ ' glacier runoff $(9.32$ $\mu \mathrm{M})$ is equivalent to the concentrations in the ' $\mathrm{O}$ ' glacier floodplain. The fjord samples collected at our second field site showed that the glacial runoff in the fjord had dFe concentrations $(2.3-2.9 \mu \mathrm{M})$ within the range of that observed in the ' $\mathrm{N}$ ' glacier runoff, but the fjord water itself had a substantially lower dFe concentration $(0.04 \mu \mathrm{M})$.

The particulate $\mathrm{Fe}(\mathrm{pFe})$ concentrations were higher for each sample type compared to the $\mathrm{dFe}$ concentrations (Figure 1 and Table 1). The highest total (oxyhydr)oxide pFe concentrations were observed in the ' $N$ ' glacier runoff and the proglacial lake. Interestingly, both the ' $\mathrm{M}$ ' and ' $\mathrm{O}$ ' glacier runoff $\mathrm{pFe}$ concentrations were lower than the observed range for the ' $N$ ' glacier runoff. The fjord water had the lowest total (oxyhydr)oxide Fe concentration. The percent contribution from the 'labile 
204 Fe' and 'crystalline Fe' fractions to the total (oxyhydr)oxides extracted is also shown in 205 Table 1. The \%labile and \%crystalline contributions in the 'N', 'M', and 'O' glacier 206 runoff is generally split evenly between the two fractions, with some exceptions among 207 the 'N' glacier samples. The proglacial lake and lake outflow total (oxyhydr)oxide Fe 208 also has approximately equal contributions from the labile and crystalline fractions. 209 However, the supraglacial sample had a much greater contribution from the cyrstailline 210 fraction (84.6\%) compared to the labile fraction (15.4\%). Conversely, in the fjord sample, 211 all of the leachable pFe was extracted in the labile fraction. The Fe concentration and \% $212 \mathrm{Fe}(\mathrm{g} / \mathrm{g})$ extracted in each particulate fraction is presented in Table 2. Generally, the 213 average $\% \mathrm{Fe}$ is higher in the crystalline fraction compared to the labile fraction for all 214 the sample types (excluding the fjord sample). The highest \% Fe values were observed in 215 the proglacial lake and lake outflow, and the lowest values were observed in the fjord 216 sample.

A higher resolution time-series at ' $N$ ' glacier revealed seasonal variability in both the $\mathrm{dFe}$ and $\mathrm{pFe}$ concentrations (Figure 3). Generally, the four May runoff samples had higher $\mathrm{dFe}$ concentrations $(3.21-9.32 \mu \mathrm{M})$ compared to the July runoff $(2.20-4.27$ $\mu \mathrm{M})$ (Figure 3c). The dFe concentrations generally corresponded with previously reported dissolved organic carbon (DOC) concentrations, except for the late May runoff waters, which had lower DOC concentrations but high $\mathrm{dFe}$ concentrations. The $\mathrm{pFe}$ concentrations were more variable; the lowest discharge (day 142) coincided with one of the lowest pFe concentrations, but the later May samples (days 146 - 153) generally had higher pFe concentrations than the July samples (Figure 3e). The total suspended sediment (TSS) in the N glacier runoff waters sampled is shown in Figure 3d. Generally, the $\mathrm{pFe}$ concentrations correlated with the TSS; however, the highest $\mathrm{pFe}$ concentrations were observed in late May, whereas the highest TSS concentrations occurred in the July runoff waters. The dissolved and particulate Fe concentrations generally varied in tandem (i.e. higher $\mathrm{dFe}$ correlated with higher $\mathrm{pFe}$ ), with the exception of a sample taken on the lowest discharge day, when the $\mathrm{dFe}(7.06 \mu \mathrm{M})$ was among the highest recorded for the 'N' outflow waters, and the pFe was the lowest. The flux of both dissolved (Figure 4) and 
particulate (Figure 4) Fe was calculated on days with complementary discharge and concentration data. Generally, both the $\mathrm{dFe}$ and $\mathrm{pFe}$ fluxes were driven by the discharge rather than by the Fe concentration. Finally, estimates for the dissolved and labile particulate Fe fluxes for subglacially-derived runoff streams exiting ' $M$ ' and ' $N$ ' glacier, and the supraglacially-sourced Waterfall stream are presented in Table 3. Total annual dissolved and labile particulate $\left(\mathrm{pFe}_{1)}\right.$ Fe fluxes were calculated for the Greenland ice sheet using the discharge-weighted average $\mathrm{dFe}$ and $\mathrm{pFe}_{1}$ concentrations in the ' $\mathrm{N}$ ' glacier runoff (Table 3).

\section{Discussion}

4.1. Seasonal dissolved Fe variability in glacial meltwater runoff The seasonal discharge-weighted average dFe concentration for ' $\mathrm{N}$ ' glacier runoff was $3.7 \mu \mathrm{M}$, similar to the average $\mathrm{dFe}$ concentration from the adjacent, larger ' $\mathrm{M}$ ' glacier $(3.8 \mu \mathrm{M})$. This value is higher than that previously reported for Greenland glacial discharge $(\mathrm{dFe}(<0.4 \mu \mathrm{m})=54 \mathrm{nM})$ (Statham et al., 2008), Antarctic basal ice $(\mathrm{dFe}(<0.2$ $\mu \mathrm{m})=0.09-2.0 \mathrm{nM})$ (Raiswell et al., 2008), and average Arctic river dFe concentrations (Ob, Yenisey rivers $(\mathrm{dFe}<0.4 \mu \mathrm{m}): 251-654 \mathrm{nM})$ (Dai, 1995). The subglacially-routed ' $\mathrm{N}$ ' and ' $\mathrm{M}$ ' glacial runoff dFe concentrations were much higher than the $\mathrm{dFe}$ in the supraglacial ice and Waterfall stream (comprised primarily of supraglacially-routed meltwater), thus indicating that passage through the subglacial environment dramatically alters the $\mathrm{dFe}$ signature of glacial runoff relative to its origin as dilute ice-melt. There are several potential controls on the dFe concentrations observed in the ' $\mathrm{N}$ ' glacier runoff. First, the high May dFe concentrations may be a result of the higher dissolved organic carbon (DOC) concentrations observed in these waters (Figure 3b), which can complex both ferrous $\left(\mathrm{Fe}^{2+}\right)$ and ferric $\left(\mathrm{Fe}^{3+}\right)$ iron to keep it in solution (Kuma and Nishioka, 1996; Rue, 1995; Rue and Bruland, 1997). Indeed, the highest ' $N$ ' glacier runoff dFe concentration was on the lowest discharge day when DOC was extremely high ( $\sim 342$ $\mu \mathrm{M})$. Alternatively, in our previous work at ' $\mathrm{N}$ ' glacier, we show that the subglacial 
262 drainage system likely accesses hypoxic or anoxic regions of the bed in the early season, 263 particularly on the lowest discharge day (Bhatia et al., in prep); under such conditions

$264 \mathrm{Fe}^{2+}$ is thermodynamically stable and would be transported passively into the glacier 265 runoff (Achterberg et al., 2001). Either process or a combination of the two could result

266 in the comparatively higher dFe concentrations in May. Finally, it is important to note 267 that our dissolved fraction may include colloidal nanoparticles, and thus, may not be truly 268 “dissolved”(Raiswell et al., 2006). Previous examination of fine-grained sediment 269 fractions from alpine, Arctic, and Antarctic glaciers revealed the universal presence of iron (oxyhydr)oxide nanoparticles . These nanoparticles were generally less than $10 \mathrm{~nm}$ in diameter, and could be present as isolated grains or aggregates and be separated from

272 or attached to (alumino)silicate grains (Raiswell et al., 2006). The inclusion of these nanoparticles in the dissolved load may explain the comparatively high ( $\mu \mathrm{M}$ range) July

$274 \mathrm{dFe}$ concentrations. It is conceivable that this colloidal fraction is also bioavailable 275 (Chen, 2001; Raiswell et al., 2006; Wu, 2001), but such a discussion is beyond the scope 276 of this paper.

277

\subsection{Particulate Fe export in glacial meltwater runoff}

The leachable $\mathrm{pFe}$ fraction lends insight into the Fe content of the underlying bedrock and sediment from which the dFe load in the ' $\mathrm{N}$ ' glacial runoff is ultimately derived. The $\mathrm{pFe}$ concentrations in the ' $\mathrm{N}$ ' glacier runoff were well correlated with the TSS concentrations, indicating that the high $\mathrm{pFe}$ and $\mathrm{dFe}$ concentrations observed may entirely be a function of TSS. However, the fact that the highest $\mathrm{pFe}$ concentrations were observed in late May when TSS was not as high as in July, hints that other hydrological or chemical controls on the observed Fe concentrations may also be present. Within the pFe fraction, the labile Fe component has the most implications for downstream Fe fertilization as, in this study, it best approximates the abundance and export of bioavailable Fe. The \% labile $\mathrm{Fe}(\mathrm{g} / \mathrm{g})$ in the ' $\mathrm{N}$ ' glacial runoff (on average $\sim 1.5 \%$ ) is below the average Fe abundance in continental crust ( $\sim 5.6 \%$ ) (Taylor, 1964), but larger than the percent of highly reactive Fe $(0.25 \%)$ measured by Raiswell et al., (2006) in 
291 subglacial sediments $(<2 \mu \mathrm{m})$ beneath Glacier d'Argentiere (French Alps), which has a

292 similar granite/gneiss bedrock lithology to that beneath the GrIS. In this study Raiswell et

293 al., (2006) used a buffered sodium dithionite solution to extract their highly reactive Fe

$294\left(\mathrm{Fe}_{\mathrm{HR}}\right)$ fraction, equivalent to the leach used in this study to dissolve the labile particulate

295 fraction. However, using a subsequent $\mathrm{HF}-\mathrm{HClO}_{4}-\mathrm{HNO}_{3}$ leach Raiswell et al., (2006)

296 was able to measure a total \%Fe of $2.82 \%$ from the Glacier d'Argentiere subglacial

297 sediments, indicating that most of the Fe was likely comprised of non-labile alumino-

298 silicate Fe. Conversely, suspended sediments from meltwater runoff at

299 Finsterwalderbreen glacier (Svalbard) revealed that the majority (70\%) of the Fe was

300 bioavailable $\left(5.51 \% \mathrm{Fe}_{\mathrm{HR}}\right)$. However, Finsterwalderbreen is unique in that its bedrock

301 lithology is comprised of schists, siltstones, sandstones, and shales. The results from the

302 ' $N$ ' glacier runoff are distinct in that they lie between the values measured at Glacier

303 d'Argnitere and Finsterwalderbreen, with on average $50 \%$ of the total Fe being labile.

304 The fact that the $\mathrm{pFe}$ in the supraglacial ice was primarily comprised of crystalline $\mathrm{Fe}$

305 (85\% (hydr)oxide contribution), indicates that the labile pFe fraction in the ' $N$ ' glacier

306 runoff likely originates from the subglacial environment, instead of from wind-deposited

307 sediment on the glacier surface. Potential subglacial sources of labile pFe could be a by-

308 product of mechanical and/or chemical weathering, or subglacial microbial activities

309 (Raiswell et al., 2006; Sharp et al., 1999; Tranter et al., 2002).

\subsection{Proglacial processing of glacially-derived Fe and export to the coastal}

312 ocean

313 Based on results from the point samples collected in May, we propose that proglacial

314 processing adds dissolved Fe to runoff originally exported at the glacier snout. In

315 particular, processes in the proglacial lake increase $\mathrm{dFe}$, while $\mathrm{pFe}$ decreases along the

316 lake length, implying the dissolved and particulate Fe pools are decoupled in this lake

317 and likely controlled by separate mechanisms. The lake dFe concentration may be

318 elevated in May because regions of the lake may be driven to anoxia beneath the seasonal

319 ice cover, serving to keep $\mathrm{Fe}^{2+}$ in solution. Additionally, organic carbon concentrations 
were very high $(\sim 614 \mu \mathrm{M})$ in the lake in May (Figure 2$)$, and thus, Fe stabilization with organic ligands may also contribute to the high dFe concentrations (Rue and Bruland, 1997). Alternatively, the lower suspended sediment (oxyhydr)oxide concentrations in the lake outflow may also be due to larger particles setting out along the length of the proglacial lake. Since we do not have a sample from the fjord at this site it is difficult to speculate what portion of the Fe load ultimately is exported to the coastal ocean. The fjord samples from our secondary site hint that a significant fraction of both the dissolved and particulate pools may be removed in the near coastal ocean (Boyle et al., 1977). In this way, glacial systems may be akin to river systems, where river Fe is generally depleted in estuaries prior to their entry into the marine environment via removal of the colloidal fraction by aggregation and deposition (Boyle et al., 1977; Raiswell et al., 2006; Wen et al., 1999). Additional transects from the ice sheet terminus to the coastal ocean are needed to confirm this hypothesis, and discover the mechanisms by which glacialderived Fe is removed. However, the dissolved $(40 \mathrm{nM})$ Fe concentration in the fjord water is similar to Arctic river (e.g. Ob, Yenisey) estuary systems (Dai, 1995), is orders of magnitude higher than the average dissolved Fe concentration in the ocean $(0.7 \mathrm{nM})$ (Sarmiento and Gruber, 2006), and the particulate Fe exported is comprised entirely of labile Fe. These observations hint that there is potential for the labile Fe flux to be enhanced in the proglacial region prior to coastal ocean export, and that though a large proportion of the dissolved and particulate Fe load is removed, a comparatively significant fraction may still be exported to the coastal ocean.

4.4. Fe export from the Greenland ice sheet and impact on primary productivity Using the discharge-weighted dissolved and labile particulate $\mathrm{Fe}\left(\mathrm{pFe}_{1}\right)$ concentrations from 'N' glacier and the mean (1995-2007) GrIS estimated annual meltwater runoff of $397 \mathrm{~km}^{3} / \mathrm{y}$ (Mernild et al., 2009) we estimate annual $\mathrm{dFe}$ and $\mathrm{pFe} \mathrm{e}_{1}$ fluxes for the entire GrIS to be $1.5 \times 10^{9}$ moles/year and $3.6 \times 10^{10}$ moles/y, respectively. Previously, Raiswell et al., (2006) hypothesized that the labile Fe in glacial meltwaters would likely 
be removed during estuarine transport, similar to riverine Fe. Thus, if we assume an estuarine removal factor of $90 \%$ (Boyle et al., 1977), our $\mathrm{dFe}$ flux equates to $0.01 \mathrm{Tg} / \mathrm{y}$ of dissolved Fe, an order of magnitude lower than the minimum estimated range for the annual global riverine $\mathrm{dFe}$ flux $(\mathrm{dFe}(<0.45 \mu \mathrm{m}) 0.2-2.0 \mathrm{Tg} / \mathrm{y})(\mathrm{de}$ Baar and de Jong, 2001; Haese, 2000; Raiswell et al., 2006). Comparatively, this estuarine-corrected GrIS annual $\mathrm{dFe}$ flux $\left(1.5 \times 10^{8}\right.$ moles/year $)$ is higher than that estimated by Statham et al., (2008) using the same annual discharge $\left(\mathrm{dFe}(<0.4 \mu \mathrm{m}) \sim 2.1 \times 10^{7} \mathrm{moles} / \mathrm{y}\right)$, due to the higher $\mathrm{dFe}$ concentrations measured in this study. The combined, estuarine-corrected $\mathrm{dFe}$ and $\mathrm{pFe}_{1}$ is $\sim 3.8 \times 10^{9}$ moles/year $(0.21 \mathrm{Tg} / \mathrm{y})$. The global Fe flux from atmospheric dust to the oceans is $\sim 16 \mathrm{Tg} / \mathrm{y}$, and the North Atlantic receives $\sim 43 \%$ of this annual flux, which represents the primary bioavailable Fe input this ocean (Jickells et al., 2005). Assuming a range of solubility proportions from 1 to 10\% (Fan et al., 2006; Sarmiento and Gruber, 2006), this equates to an annual soluble Fe dust flux to the North Atlantic between 0.07-0.7 Tg/y. Thus, our dissolved and particulate labile Fe flux from the GrIS is of the same order of magnitude as the soluble Fe dust estimate, indicating that glaciallysourced $\mathrm{Fe}$ is capable of providing a quantitatively significant portion of labile dissolved and particulate Fe to surrounding coastal oceans. Indeed, a recent study analyzing spring phytoplankton bloom dynamics from 1998-2008 using SeaWiFS satellite ocean chlorophyll data noted a strong correlation between peak bloom magnitude in the north Labrador Sea, off the coast of west Greenland, and GrIS runoff $\left(\mathrm{r}^{2}=0.81\right)$ (FrajkaWilliams and Rhines, 2010). This observation highlights the potential for labile Fe in GrIS runoff to stimulate primary productivity in the North Atlantic.

\section{Conclusions}

In this study, we examined dissolved $(<0.2 \mu \mathrm{m})$ and particulate $(>0.7 \mu \mathrm{m}) \mathrm{Fe}$ in glacial runoff from the GrIS. We find high (micro-molar) Fe concentrations in the dissolved fraction that may be caused by: (1) complexing of Fe with DOC, allowing Fe to remain in solution, (2) colloidal nanoparticles present in the defined dissolved fraction, and (3) anoxic regions at the glacier bed, allowing $\mathrm{Fe}^{2+}$ to be thermodynamically stable. 
378 Furthermore, results from this study hint that reactions in the proglacial region may

379 enhance dissolved Fe concentrations prior to export to the marine environment. We

380 estimate annual dissolved and labile particulate fluxes from the GrIS to be equivalent to

381 that of the annual soluble Fe dust flux to the North Atlantic Ocean, indicating that

382 glacially-sourced Fe may provide a quantitatively significant flux of Fe to surrounding

383 coastal oceans.

384

385 Acknowledgments. This research was supported the: the WHOI Clark Arctic Research

386 Initiative (EBK, SBD, MAC), the National Science Foundation (MAC), the WHOI

387 Climate Change Institute (MPB), and a Horton Hydrology Grant (MPB). I am grateful to

388 Scot Birdwhistell for assistance with the ICP-MS analyses, to Phoebe Lam, Dan

389 Ohnemus, and Ben Gready for helpful conversations, and to Ben Gready, Alison

390 Criscitiello, and Matt Evans for their valuable assistance in the field.

391 


\section{References}

Achterberg, E.P., Holland, T.W., Bowie, A.R., Mantoura, R.F.C., Worsfold, P.J., 2001. Determination of iron in seawater. Analytica Chimica Acta 442, 1-14.

Bartholomew, I., Nienow, P., Mair, D., Hubbard, A., King, M.A., Sole, A., 2010. Seasonal evolution of subglacial drainage and acceleration in a Greenland outlet glacier. Nat. Geosci. 3, 408-411.

Bhatia, M., Das, S.B., Kujawinski, E.B., Henderson, P., Burke, A., Charette, M.A., 2011. Seasonal evolution of water contributions to discharge from a Greenland outlet glacier: Insight from a new isotope-mixing model J. Glaciol. 57, 929-941.

Bhatia, M., Das, S.B., Xu, X.L., Charette, M., Kujawinski, E.B., in prep. Organic carbon export from the Greenland ice sheet

Blain, S., Guieu, C., Claustre, H., Leblanc, K., 2004. Availability of iron and major nutrients for phytoplankton in the northeast Atlantic Ocean. Limnol. Oceanogr.

Boyle, E.A., Edmond, J.M., Sholkovitz, E.R., 1977. The mechanism of iron removal in estuaries. Geochim. Cosmochim. Acta 41, 1313-1324.

Charette, M.A., Sholkovitz, E.R., Hansel, C.M., 2005. Trace element cycling in a subterranean estuary: Part 1. Geochemistry of the permeable sediments. Geochim. Cosmochim. Acta 69, 2095-2109.

Chen, M., 2001. Bioavailability of natural colloid-bound iron to marine plankton: Influences of colloidal size and aging. Limnol. Oceanogr.

Crusius, J., Schroth, A.W., Gasso, S., Moy, C.M., Levy, R.C., Gatica, M., 2011. Glacial flour dust storms in the Gulf of Alaska: Hydrologic and meteorological controls and their importance as a source of bioavailable iron. Geophys. Res. Lett. 38, L06602.

Dai, M.H., 1995. First data on trace metal level and behaviour in two major Arctic riverestuarine systems ( $\mathrm{Ob}$ and Yenisey) and in the adjacent Kara Sea, Russia. Earth Planet. Sci. Lett.

Das, S.B., Joughin, I., Behn, M.D., Howat, I.M., King, M.A., Lizarralde, D., Bhatia, M.P., 2008. Fracture propagation to the base of the Greenland Ice Sheet during supraglacial lake drainage. Science 320, 778-781. 
461

462

463

464

465

466

467

468

469

470

471

472

473

474

475

de Baar, H.J.W., de Jong, J.T.M., 2001. Distribution, sources and sinks of iron in seawater, in: Turner, D.R., Hunter, K.A. (Eds.), The Biogeochemistry of Iron in Seawater. Wiley, New York, pp. 122-153.

Escher, A., 1971. Map Sheet no. 3 Sondre Stromfjord - Nugssu aq Geological Maps of Greenland 1:500,000. Geological Survey of Denmark and Greenland (GEUS), Copenhagen.

Fan, S.M., Moxim, W.J., Levy, H., 2006. Aeolian input of bioavailable iron to the ocean. Geophys. Res. Lett. 33.

Frajka-Williams, E., Rhines, P.B., 2010. Physical controls and interannual variability of the Labrador Sea spring phytoplankton bloom in distinct regions. Deep-Sea Research Part I-Oceanographic Research Papers 57, 541-552.

Haese, R.R., 2000. The reactivity of iron, in: Zabel, M. (Ed.), Marine Geochemistry. Springer-Verlag, Berlin, pp. 233-261.

Hall, G.E.M., Vaive, J.E., Beer, R., Hoashi, M., 1996. Selective leaches revisited, with emphasis on the amorphous Fe oxyhydroxide phase extraction. Journal of Geochemical Exploration 56, 59-78.

Jickells, T.D., An, Z.S., Andersen, K.K., Baker, A.R., Bergametti, G., Brooks, N., Cao, J.J., Boyd, P.W., Duce, R.A., Hunter, K.A., Kawahata, H., Kubilay, N., laRoche, J., Liss, P.S., Mahowald, N., Prospero, J.M., Ridgwell, A.J., Tegen, I., Torres, R., 2005. Global iron connections between desert dust, ocean biogeochemistry, and climate. Science 308, 67-71.

Kuma, K., Nishioka, J., 1996. Controls on iron (III) hydroxide solubility in seawater: The influence of $\mathrm{pH}$ and natural organic chelators. Limnol. Oceanogr.

Martin, J.H., 1990. Glacial-interglacial CO2 change: The iron hypothesis. Paleoceanography.

Martin, J.H., Fitzwater, S.E., Michael Gordon, R., Hunter, C.N., Tanner, S.J., 1993. Iron, primary production and carbon-nitrogen flux studies during the JGOFS North Atlantic bloom experiment. Deep Sea Research Part II: Topical Studies in Oceanography 40, 115-134.

Martin, J.H., Gordon, R.M., Fitzwater, S.E., 1990. Iron in Antarctic waters. Nature 345, 156-158. 
Mernild, S.H., Liston, G.E., Hiemstra, C.A., Steffen, K., Hanna, E., Christensen, J.H., 2009. Greenland Ice Sheet surface mass-balance modelling and freshwater flux for 2007, and in a 1995-2007 perspective. Hydrol. Processes 23, 2470-2484.

Mills, M.M., Ridame, C., Davey, M., La Roche, J., Geider, R.J., 2004. Iron and phosphorus co-limit nitrogen fixation in the eastern tropical North Atlantic. Nature 429, 292-294.

Moore, C.M., Mills, M.M., Milne, A., Langlois, R., Achterberg, E.P., Lochte, K., Geider, R.J., La Roche, J., 2006. Iron limits primary productivity during spring bloom development in the central North Atlantic. Global Change Biol. 12, 626-634.

Moore, J.K., Doney, S.C., Glover, D.M., Fung, I.Y., 2001. Iron cycling and nutrientlimitation patterns in surface waters of the World Ocean. Deep Sea Research Part II: Topical Studies in Oceanography 49, 463-507.

Nielsdottir, M.C., Moore, C.M., Sanders, R., Hinz, D.J., Achterberg, E.P., 2009. Iron limitation of the postbloom phytoplankton communities in the Iceland Basin. Global Biogeochem. Cycles 23, GB3001.

Raiswell, R., Benning, L.G., Tranter, M., Tulaczyk, S., 2008. Bioavailable iron in the Southern Ocean: the significance of the iceberg conveyor belt. Geochem. Trans. 9.

Raiswell, R., Tranter, M., Benning, L.G., Siegert, M., De'ath, R., Huybrechts, P., Payne, T., 2006. Contributions from glacially derived sediment to the global iron (oxyhydr)oxide cycle: Implications for iron delivery to the oceans. Geochim. Cosmochim. Acta 70, 2765-2780.

Rue, E.L., 1995. Complexation of iron (III) by natural organic ligands in the Central North Pacific as determined by a new competitive ligand equilibration/adsorptive cathodic stripping method. Mar. Chem., 117-138.

Rue, E.L., Bruland, K.W., 1997. The role of organic complexation on ambient iron chemistry in the equatorial Pacific Ocean and the response of a mesoscale iron addition experiment. Limnol. Oceanogr. 42, 901-910.

Sarmiento, J., Gruber, N., 2006. Ocean Biogeochemical Dynamics. Princeton University Press, Princeton, NJ.

Sharp, M., Parkes, J., Cragg, B., Fairchild, I.J., Lamb, H., Tranter, M., 1999. Widespread bacterial populations at glacier beds and their relationship to rock weathering and carbon cycling. Geology 27, 107-110. 
Statham, P.J., Skidmore, M., Tranter, M., 2008. Inputs of glacially derived dissolved and colloidal iron to the coastal ocean and implications for primary productivity. Global Biogeochem. Cycles 22.

Taylor, S.R., 1964. Abundance of chemical elements in the continental crust: a new table. Geochim. Cosmochim. Acta.

Tranter, M., Sharp, M.J., Lamb, H.R., Brown, G.H., Hubbard, B.P., Willis, I.C., 2002. Geochemical weathering at the bed of Haut Glacier d'Arolla, Switzerland - a new model. Hydrol. Processes 16, 959-993.

Wen, L.-S., Santschi, P., Gill, G., Paternostro, C., 1999. Estuarine trace metal distributions in Galveston Bay: importance of colloidal forms in the speciation of the dissolved phase. Mar. Chem. 63, 185-212.

Wu, J., 2001. Soluble and Colloidal Iron in the Oligotrophic North Atlantic and North Pacific. Science 293, 847-849. 
Table 1. Ranges of dissolved $(<0.2 \mu \mathrm{m})$ and particulate $(>0.70 \mu \mathrm{m})$ concentrations measured in different samples from the Greenland ice sheet margin. The range of \% contributions from labile and crystalline fractions to the total (oxyhydr)oxide Fe is shown for all the samples, and the average \% labile and crystalline contribution is also shown for the ' $\mathrm{N}$ ' glacier runoff. The fjord samples (*) are from the secondary (northern) field site. The number of samples for each sample type (dissolved (d) and particulate (p)) is shown in the "n" column.

\begin{tabular}{|c|c|c|c|c|c|c|}
\hline \multirow[t]{2}{*}{ Sample Type } & \multirow[t]{2}{*}{$\mathbf{n}_{\mathbf{d}}$} & \multirow{2}{*}{$\begin{array}{l}\text { Dissolved Fe } \\
\text { range }(\mu M) \\
\end{array}$} & \multirow[t]{2}{*}{$\mathbf{n}_{\mathrm{p}}$} & \multicolumn{3}{|c|}{ Particulate Fe range $(\mu \mathrm{M})$} \\
\hline & & & & $\begin{array}{l}\text { Total } \\
\text { (oxyhydr)oxide Fe }\end{array}$ & $\%$ labile & $\%$ crystalline \\
\hline \multicolumn{7}{|l|}{ End-member samples } \\
\hline Supraglacial Ice & 1 & 0.11 & 1 & 27.61 & 15.4 & 84.6 \\
\hline Groundwater & 6 & $0.30-431.2$ & 0 & -- & -- & -- \\
\hline \multicolumn{7}{|l|}{ Runoff samples } \\
\hline 'N' glacier runoff & 13 & $2.2-9.3$ & 17 & $50.39-321.58$ & $\begin{array}{l}35.9-75.3 \\
\text { mean }=49.9\end{array}$ & $\begin{array}{l}20.7-64.1 \\
\text { mean }=50.1\end{array}$ \\
\hline 'M' glacier runoff & 2 & $3.5-4.1$ & 1 & 25.53 & 49.1 & 50.1 \\
\hline 'O' glacier runoff & 1 & 10.0 & 1 & 29.98 & 46.1 & 53.1 \\
\hline Waterfall stream & 1 & 0.19 & 0 & -- & -- & -- \\
\hline \multicolumn{7}{|l|}{ Proglacial samples } \\
\hline Proglacial Lake & 2 & $4.8-5.2$ & 1 & 278.11 & 44.5 & 55.5 \\
\hline Lake Outflow & 1 & 17.4 & 1 & 45.37 & 48.7 & 51.3 \\
\hline \multicolumn{7}{|l|}{ Fjord samples } \\
\hline Glacial runoff in fjord & 2 & $2.3-2.9$ & 0 & -- & -- & -- \\
\hline Fjord water & 1 & 0.04 & 1 & 0.129 & 100 & 0 \\
\hline
\end{tabular}


Table 2. Concentrations $(\mu \mathrm{M})$ and $\% \mathrm{Fe}(\mathrm{g} / \mathrm{g})$ in different particulate $(>0.70 \mu \mathrm{m})$ samples from the Greenland ice sheet margin for the labile and crystalline fractions. For the supraglacial and ' $\mathrm{O}$ ' glacier runoff samples, it was not possible to accurately determine a weight for the total sediment on the filter. The crystalline Fe concentration of the Fjord sample was below the detection limit (BDL) of the mean process blank.

\begin{tabular}{|l|l|l|l|l|}
\hline Sample Type & $\begin{array}{l}\text { Mean labile } \\
\text { concentration }(\boldsymbol{\mu M})\end{array}$ & $\begin{array}{l}\text { Mean crystalline } \\
\text { concentration }(\boldsymbol{\mu M})\end{array}$ & $\begin{array}{l}\text { Mean labile } \\
\mathbf{\%} \text { Fe (g/g) }\end{array}$ & $\begin{array}{l}\text { Mean crystalline } \\
\mathbf{\%} \text { Fe (g/g) }\end{array}$ \\
\hline End-member samples & 23.3667 & -- & - \\
\hline Supraglacial Ice & 4.2429 & $100.4787 \pm 48.9178$ & $1.44 \pm 0.55$ & $1.55 \pm 0.80$ \\
\hline Runoff samples & 13.0074 & 0.30 & 0.35 \\
\hline 'N' glacier runoff & $90.5155 \pm 31.2864$ & -- & -- \\
\hline 'M' glacier runoff & 12.5226 & 16.1523 & \\
\hline 'O' glacier runoff & 13.8272 & 2.09 & 2.71 \\
\hline Proglacial samples & 156.0292 & 2.80 \\
\hline Proglacial Lake & 122.0833 & 23.2849 & 2.66 & BDL \\
\hline Lake Outflow & 22.0821 & & \\
\hline Fjord samples & BDL & 0.03 \\
\hline Fjord water & 0.1290 &
\end{tabular}

Table 3. Dissolved (dFe) and particulate $(\mathrm{pFe})$ Fe fluxes from Greenland glacial runoff streams sampled in this study from May 31 to July 16, 2008 (season), and estimated annual fluxes for the entire Greenland ice sheet. The Fe flux was calculated using the discharge-weighted average dissolved $(3.7 \mu \mathrm{M})$ and particulate labile fraction $(91.8 \mu \mathrm{M})$ Fe concentrations for ' $\mathrm{N}$ ' Glacier, and the average dissolved and particulate $\mathrm{Fe}$ concentrations for ' $\mathrm{M}$ ' Glacier (dissolved: $3.8 \mu \mathrm{M}$; particulate labile fraction: $12.5 \mu \mathrm{M}$ ) and the Waterfall Stream (dissolved: $0.2 \mu \mathrm{M}$ ). Values denoted by * were estimated, see methods for details. The annual Greenland ice sheet $\mathrm{dFe}$ and $\mathrm{pFe}$ fluxes were estimated using the 'N' glacier Fe values.

\begin{tabular}{|c|c|c|c|c|}
\hline Runoff Stream & $\begin{array}{l}\sim \text { Catchment } \\
\text { Area }\left(\mathbf{k m}^{2}\right)\end{array}$ & $\begin{array}{l}\text { Total Discharge } \\
\left(\mathrm{m}^{3} / \text { season }\right)\end{array}$ & $\begin{array}{l}\text { dFe flux } \\
\text { (moles/season) }\end{array}$ & $\begin{array}{l}\text { pFe labile flux } \\
\text { (moles/season) }\end{array}$ \\
\hline 'N' Glacier & 5 & $6.4 \times 10^{6}$ & $2.4 \times 10^{4}$ & $5.9 \times 10^{5}$ \\
\hline 'M' Glacier & $20-24 *$ & $2.3-2.8 \times 10^{7 *}$ & $8.7-10 \times 10^{4}$ & $2.9-3.5 \times 10^{5}$ \\
\hline Waterfall Stream & $14-32 *$ & $3.2 \times 10^{7}$ & $6.2 \times 10^{3}$ & -- \\
\hline & & $\left(\mathrm{m}^{3} /\right.$ year $)$ & (moles/y) & (moles/y) \\
\hline Greenland Ice Sheet & $1.7 \times 10^{6}$ & $523 \times 10^{9}$ & $1.9 \times 10^{9}$ & $4.8 \times 10^{10}$ \\
\hline
\end{tabular}




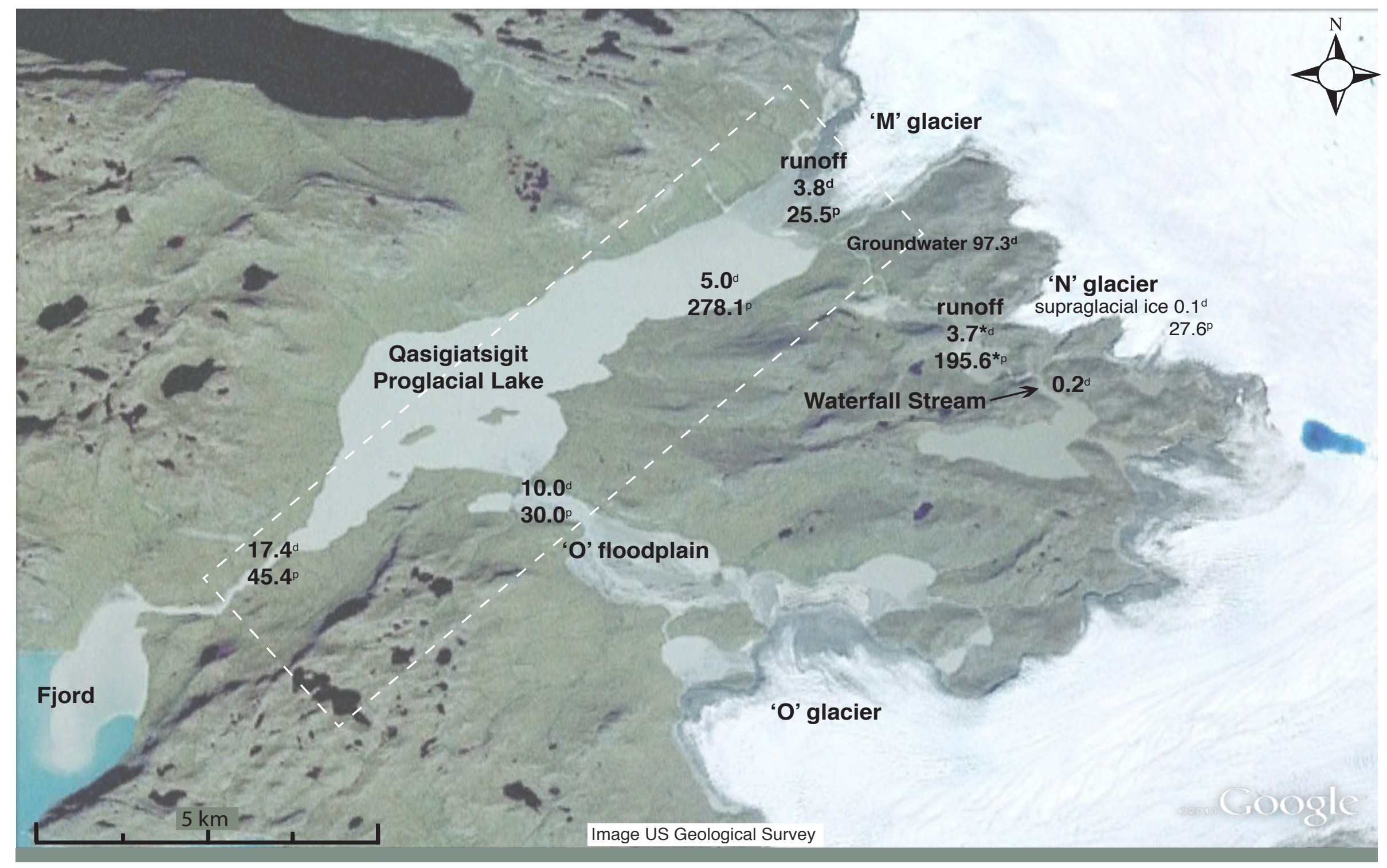

Figure 1. Map of sample locations and average dissolved (denoted by d superscript) $(<0.2 \mu \mathrm{m})$ and particulate (oxyhydr)oxide (denoted by $\mathrm{p}$ superscript) $(>0.70 \mu \mathrm{m}) \mathrm{Fe}$ concentrations in $\mu \mathrm{M}$. The ' $\mathrm{N}$ ' glacier runoff values (denoted by $*$ ) are discharge-weighted average concentrations. The region demarked by the white rectangular box is shown in figure 2 . 
(a)

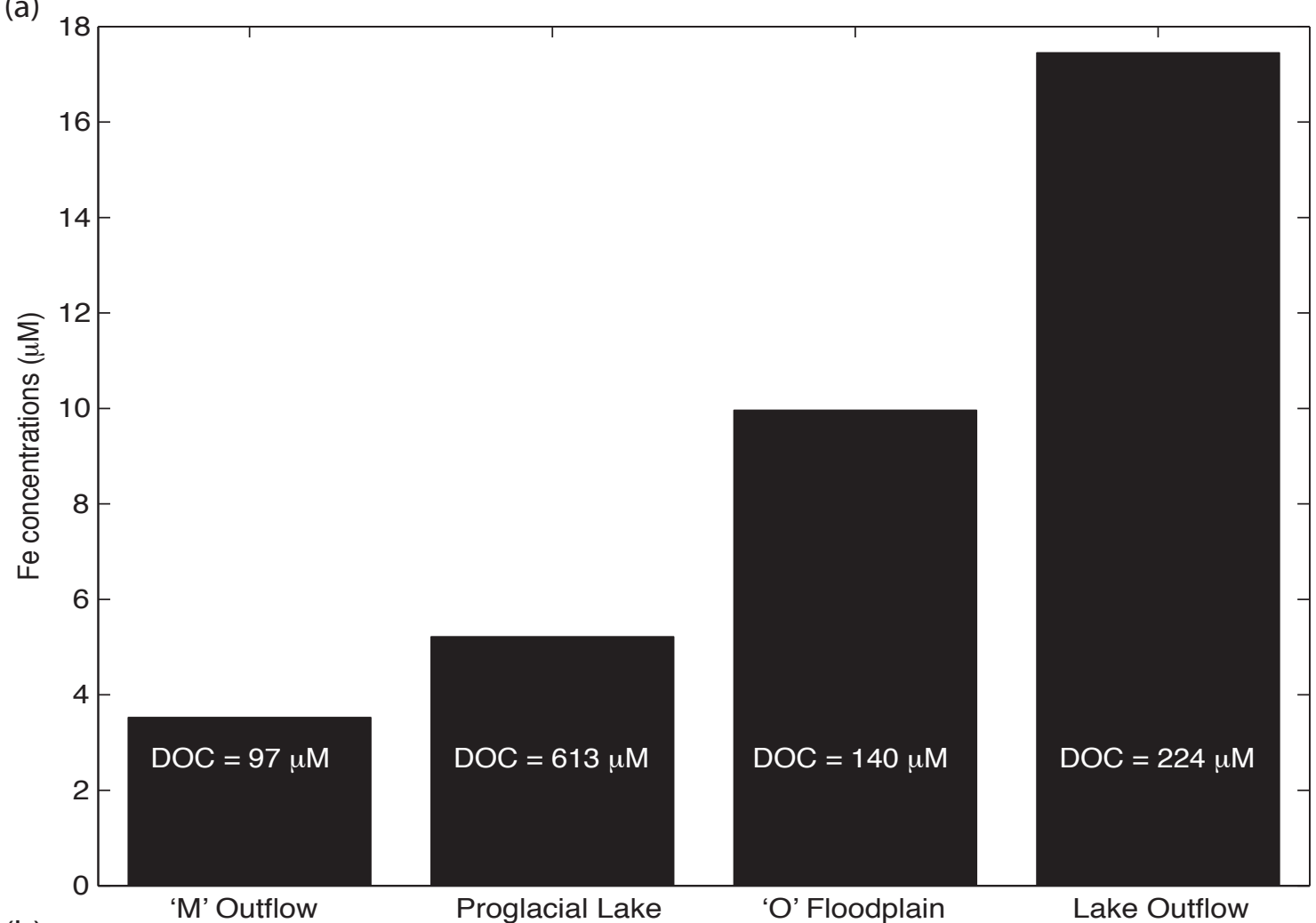

(b)

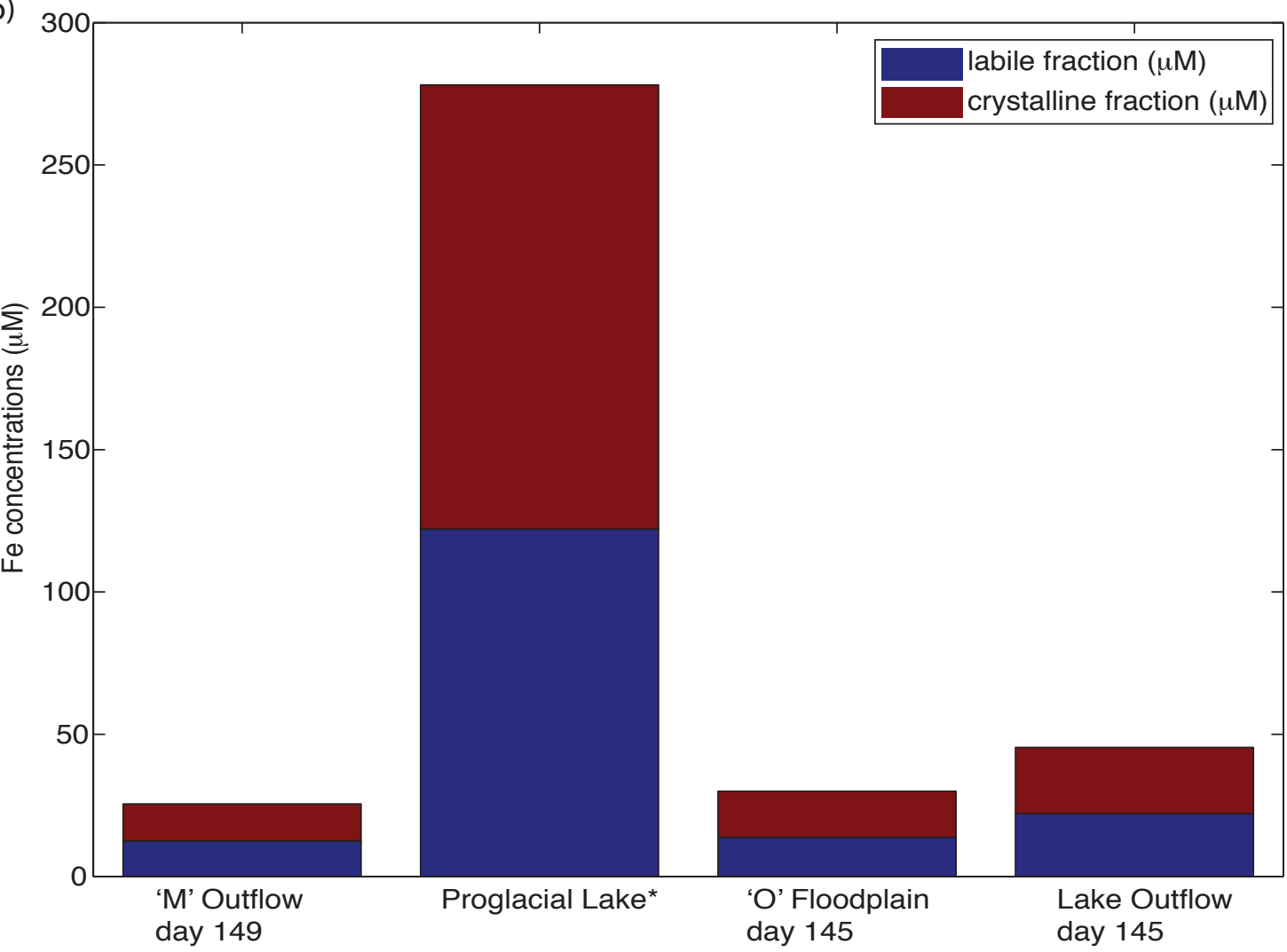

Figure 2. (a) Dissolved $(<0.2 \mathrm{~mm})$ and (b) particulate labile and crystalline fraction $(>0.7 \mathrm{~mm})$ Fe concentrations along a transact from the ' $\mathrm{M}$ ' glacier outflow to the Lake Outflow in May 2008. The dissolved and particulate samples were all taken on the same day, except for the proglacial lake, where the dissolved sample was taken on the day 141 and the particulate on day 153. The DOC concentration measured in each dissolved sample is shown in the white text. 
(a)

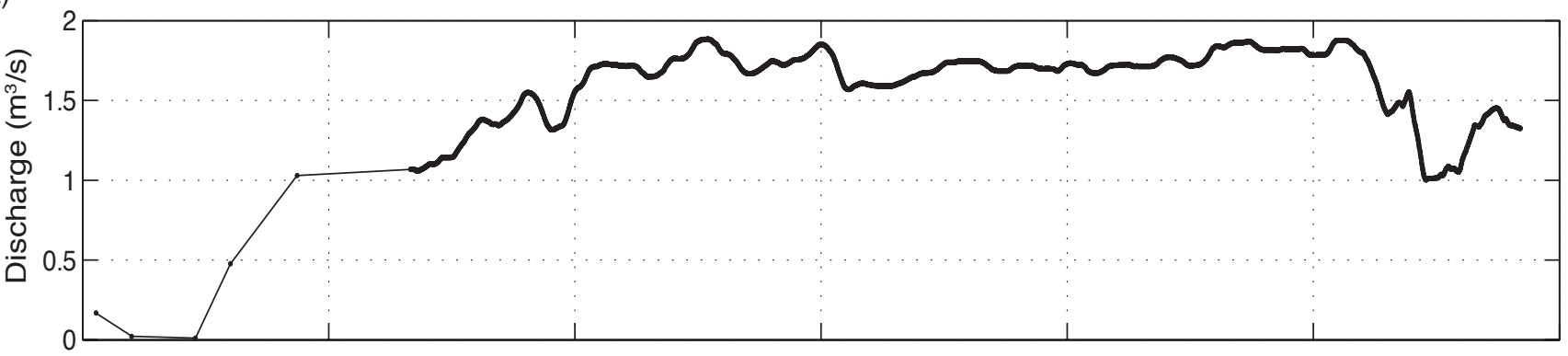

(b)

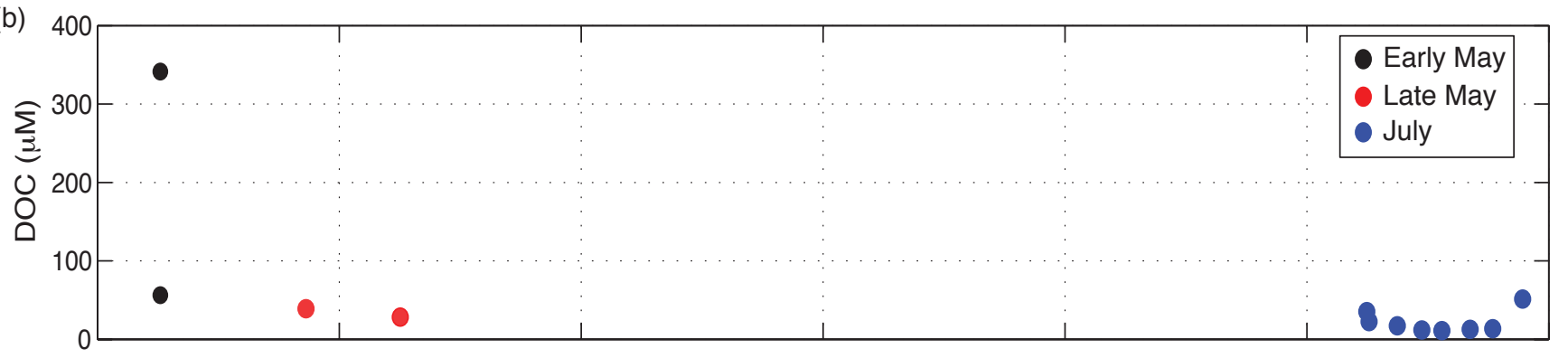

(c)

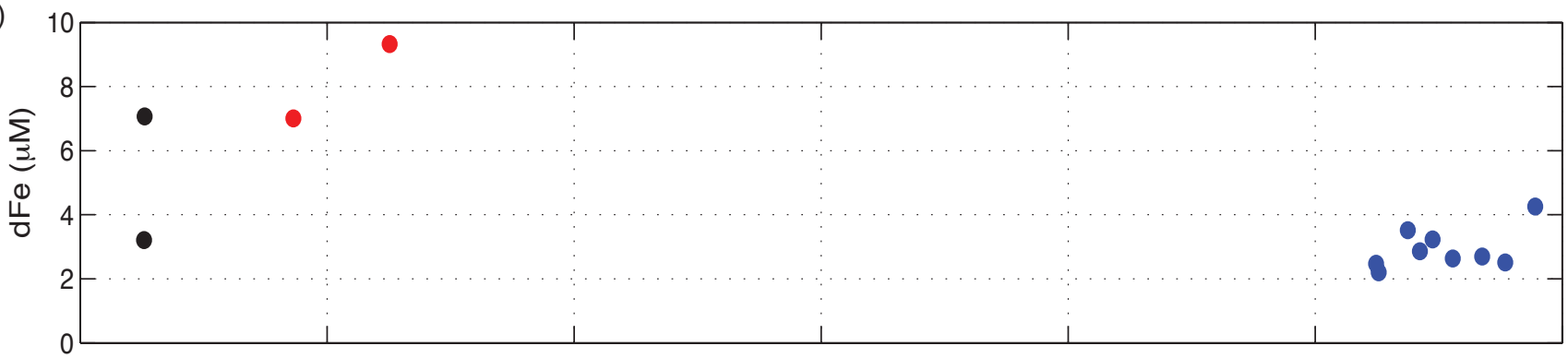

(d)
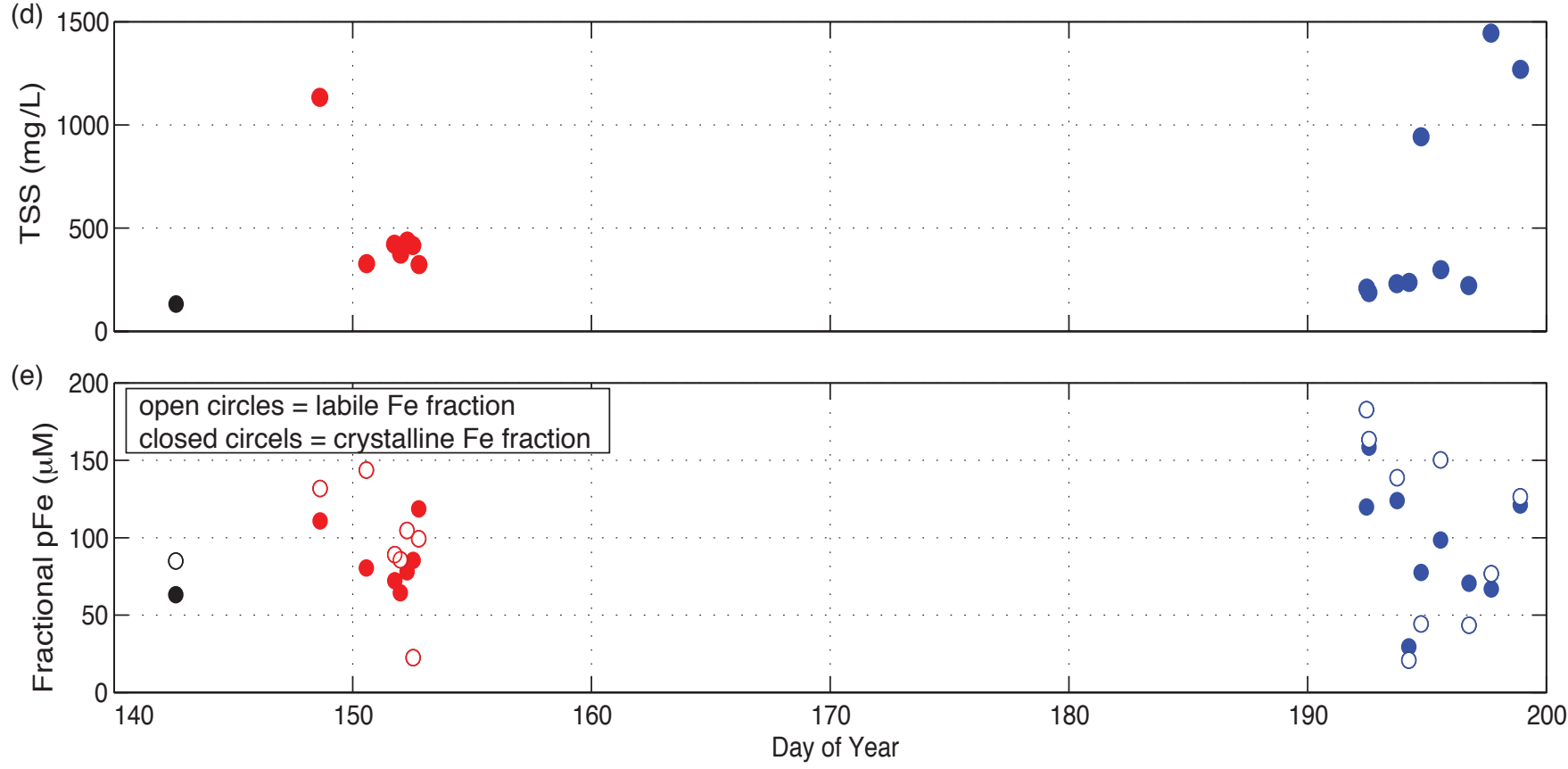

Figure 3. (a) 24-h moving average discharge (thick black line) measured at ' $N$ ' glacier (perviously reported in Bhatia et al., 2011) from May 18 to July 16, 2008; the thin black line (days 140-150) indicates discontinuous discharge . (b) Dissolved organic carbon (DOC) concentrations measured in the ' $N$ ' glacier runoff (previously reported in Bhatia et al., in prep) corresponding to the dissolved $(<0.2 \mathrm{~mm}) \mathrm{Fe}$ concentrations shown in (c). (d) Total suspended sediment (TSS) concentrations measured in the ' $\mathrm{N}$ ' glacier runoff corresponding to the particulate (oxyhydr)oxide $\mathrm{Fe}(<0.7 \mathrm{~mm}$ ) concentrations shown in (e). 

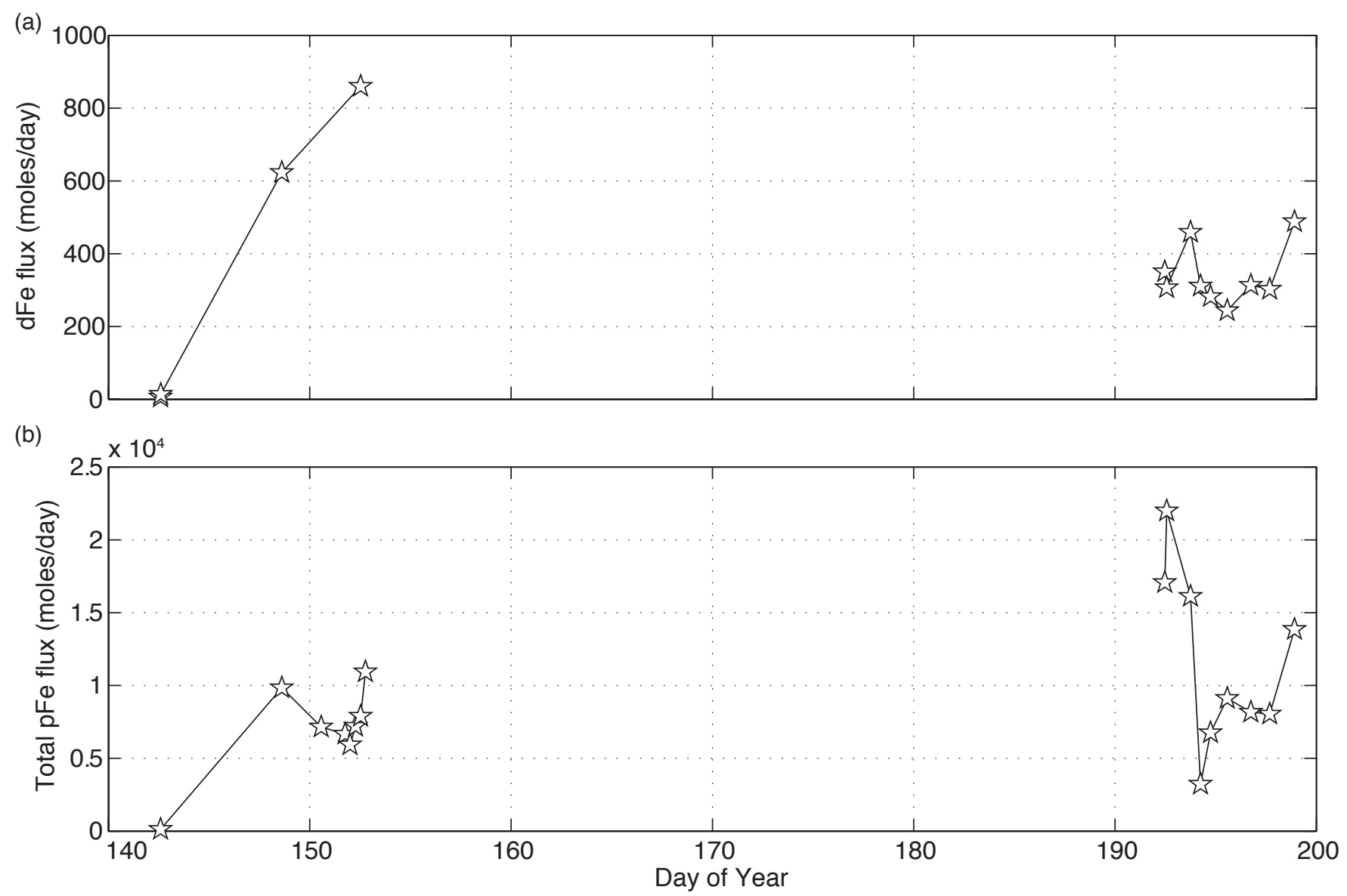

Figure 4. (a) Dissolved $(<0.2 \mathrm{~mm}$ ) and (b) total particulate (oxyhydr)oxide $\mathrm{Fe}(<0.7 \mathrm{~mm})$ flux from ' $\mathrm{N}$ ' glacier for days with complementary concentration and discharge measurements from May 18 to July 16, 2008. 


\section{Appendix A1 \\ Data Tables}

Table A1. List of samples collected from the Greenland ice sheet margin in 2008. The notation 'NM' indicates that the sample was 'not measured', 'NR' indicates that the data was 'not recorded', and 'N/A' indicates the measurement is not applicable to the sample.

Table A2. Hydrochemical parameters ( $\mathrm{pH}$, electrical conductivity (EC), and temperature) measured on-site during the Greenland ice sheet margin 2008 field campaign. The sample descriptions from Table A1 are abbreviated (in the sample type column) as follows: MO is ' $\mathrm{M}$ ' glacier outflow, $\mathrm{PW}$ is proglacial waters, $\mathrm{NO}$ is ' $\mathrm{N}$ ' glacier outflow, $\mathrm{PL}$ is proglacial lake, $\mathrm{MF}$ is ' $\mathrm{M}$ ' glacier floodplain, $\mathrm{MM}$ is marginal melt, $\mathrm{MI}$ is marginal ice, LO is lake outflow, OO is ' $\mathrm{O}$ ' glacier outflow, $\mathrm{SN}$ is snow, B is field blank, GW is groundwater, $\mathrm{T}$ is the proglacial tarn, $\mathrm{F}$ is fjord water from the second margin site, $\mathrm{SWF}$ is subglacial water in the fjord at the second margin site, and IB is ice from an iceberg at the second margin site.

Table A3. Alkalinity measured in Greenland ice sheet margin 2008 samples, using a Hach Alkalinity kit. The samples are described using the abbreviations above.

Table A4. ${ }^{222}$ Radon $(\mathrm{Rn}),{ }^{7}$ Beryllium $(\mathrm{Be})$, and oxygen isotope $\left(\delta^{18} \mathrm{O}, \delta \mathrm{D}\right)$ measurements from Greenland ice sheet inland $(2007,2008)$ and margin (2008) samples. Electrical conductivity (EC) is also shown for comparison. The samples are described using the abbreviations above for the margin site, and the following abbreviations for the inland site: NLS is the north lake stream, NLI is north lake ice, NCY is north lake cryoconite, NNLW is north north lake-water, SLLI is south lake lake-ice, SLI is south lake ice, SCY is south lake cryoconite, SLSNF is south lake fractionated snow, and NLSNF is north lake fractionated snow. Additional samples from the vicinity of Russell Glacier (Russell glacier marginal ice (RMI) and Russell glacier proglacial waters (RPW)) were also collected. Rain-water from a pond in Plymouth, MA (USA) was collected as a comparative sample for the ${ }^{7} \mathrm{Be}$ measurements.

Table A5. Dissolved $(<0.2 \mu \mathrm{m})$ nutrients measured in Greenland ice sheet margin 2008 samples. Samples are described as in above.

Table A6. Dissolved $(<0.2 \mu \mathrm{m})$ Organic Carbon (DOC) and Total Nitrogen (TN) concentrations measured in Greenland ice sheet margin 2008 samples. Samples are described as in above.

Table A7. Particulate ( $>0.7 \mu \mathrm{m})$ Organic Carbon (POC) and Particulate Organic Nitrogen (PON) concentrations in Greenland ice sheet margin 2008 samples. 
Table A8. Dissolved $(<0.2 \mu \mathrm{m})$ and particulate $(>0.7 \mathrm{um})$ radiocarbon for inland lake (2010) and margin (2008) samples.

Table A9. Dissolved $(>0.45 \mu \mathrm{m})$ anions in Greenland ice sheet margin 2008 samples.

Table A10. Dissolved $(>0.45 \mu \mathrm{m})$ cations in Greenland ice sheet margin 2008 samples.

Table A11. Dissolved (>0.2 $\mu \mathrm{m})$ iron in Greenland ice sheet margin 2008 samples.

Table A12. Particulate $(>0.2 \mu \mathrm{m})$ iron in Greenland ice sheet margin 2008 samples. 


\begin{tabular}{|c|c|c|c|c|c|}
\hline \multicolumn{6}{|c|}{ Table A1: Greenland Ice Sheet Margins 2008 Samples } \\
\hline & May Samples & & & & \\
\hline & Sample ID & Description & Latitude & Longitude & Collection Date \\
\hline & GM2 & stream in front of glacier M & $68 \mathrm{deg} 06.431^{\prime}$ & $50 \operatorname{deg} 34.026^{\prime}$ & $5 / 17 / 08 \quad 12: 30$ \\
\hline & G1 & N. margin M glacier outflow; turbid (possibly subglacial) & $68 \operatorname{deg} 04.525^{\prime}$ & $50 \operatorname{deg} 19.640^{\prime}$ & 5/17/08 13:55 \\
\hline & $\mathrm{G} 2$ & N. margin M glacier clear stream & $68 \mathrm{deg} 04.921^{\prime}$ & $50 \operatorname{deg} 20.207^{\prime}$ & 5/17/08 16:04 \\
\hline & G3 & $\mathrm{N}$ glacier stream outflow at mouth; turbid & $68 \operatorname{deg} 02.623^{\prime}$ & $50 \operatorname{deg} 16.139^{\prime}$ & $5 / 18 / 0814: 20$ \\
\hline & G4 & N glacier supraglacial (ice) meltwater at mouth; clear & $68 \operatorname{deg} 04.369^{\prime}$ & $50 \operatorname{deg} 26.921^{\prime}$ & $5 / 18 / 0814: 20$ \\
\hline & $\mathrm{G} 5$ & N glacier stream outflow at mouth; turbid & $68 \operatorname{deg} 02.623^{\prime}$ & $50 \operatorname{deg} 16.139^{\prime}$ & $5 / 19 / 0812: 41$ \\
\hline & G6 & $\mathrm{N}$ glacier stream outflow downstream at ADCP; turbid & $68 \operatorname{deg} 02.601^{1}$ & $50 \operatorname{deg} 16.614^{\prime}$ & 5/19/08 13:55 \\
\hline & G7 & South side of Clark Lake & $68 \operatorname{deg} 03.096^{\prime}$ & $50 \operatorname{deg} 20.165^{\prime}$ & $5 / 20 / 0814: 05$ \\
\hline & G8 & $\mathrm{N}$ glacier stream outflow at mouth; turbid & $68 \mathrm{deg} 02.623^{\prime}$ & $50 \operatorname{deg} 16.139^{\prime}$ & $5 / 20 / 0816: 00$ \\
\hline & G9 & $\mathrm{N}$ glacier stream outflow downstream at ADCP; turbid & $68 \mathrm{deg} 02.601^{\prime}$ & $50 \operatorname{deg} 16.614^{\prime}$ & $5 / 20 / 0816: 30$ \\
\hline & G10 & On M floodplain at intersection of waterfall and $\mathrm{N}$ streams & $68 \mathrm{deg} 03.362^{\prime}$ & $50 \operatorname{deg} 20.054^{\prime}$ & $5 / 20 / 08 \quad 16: 30$ \\
\hline & G11 & N glacier stream outflow at mouth; turbid (middle stream, high flow) & $68 \operatorname{deg} 02.623^{\prime}$ & $50 \operatorname{deg} 16.139^{\prime}$ & $5 / 21 / 0814: 23$ \\
\hline & G12 & N glacier stream outflow at mouth; turbid (right stream, low flow) & $68 \operatorname{deg} 02.623^{\prime}$ & $50 \operatorname{deg} 16.139^{\prime}$ & $5 / 21 / 0814: 10$ \\
\hline 14 & & N glacier stream outflow downstream at ADCP; turbid & $68 \operatorname{deg} 02.601^{\prime}$ & $50 \operatorname{deg} 16.614^{4}$ & $5 / 21 / 0816: 25$ \\
\hline & G14 & Waterfall stream (draining Lake 240) (HOBO site) & $68 \mathrm{deg} 02.606^{\prime}$ & $50 \mathrm{deg} 17.055^{\prime}$ & $5 / 21 / 2008$ \\
\hline & G15 & Supraglacial lake on $\mathrm{N}$ & $68 \mathrm{deg} 02.739^{\prime}$ & $50 \operatorname{deg} 15.487^{\prime}$ & $5 / 22 / 0817: 00$ \\
\hline & G15B & Replicate of G15 & $68 \mathrm{deg} 02.739^{\prime}$ & $50 \operatorname{deg} 15.487^{\prime}$ & $5 / 22 / 0817: 00$ \\
\hline & G16 & $\mathrm{N}$ glacier stream outflow at mouth; turbid & $68 \mathrm{deg} 02.623^{\prime}$ & $50 \operatorname{deg} 16.139^{\prime}$ & $5 / 22 / 0818: 00$ \\
\hline & G17 & N glacier stream outflow downstream at ADCP; turbid & $68 \mathrm{deg} 02.601^{\prime}$ & $50 \operatorname{deg} 16.614^{\prime}$ & $5 / 22 / 0818: 10$ \\
\hline & & $\mathrm{N}$ glacier stream outflow downstream at ADCP; turbid & $68 \mathrm{deg} 02.601^{\prime}$ & $50 \operatorname{deg} 16.614^{\prime}$ & $5 / 23 / 0813: 45$ \\
\hline & & $\mathrm{N}$ glacier stream outflow at mouth; turbid & $68 \operatorname{deg} 02.623^{\prime}$ & $50 \operatorname{deg} 16.139^{\prime}$ & $5 / 23 / 0817: 00$ \\
\hline & G20 & Clark Lake River feeding into fjord & $68 \operatorname{deg} 00.139^{\prime}$ & $50 \operatorname{deg} 31.032^{\prime}$ & $5 / 24 / 0819: 00$ \\
\hline $22 \mathrm{~s}$ & G21 & $\mathrm{O}$ stream on $\mathrm{O}$ floodplain & $68 \operatorname{deg} 00.959^{\prime}$ & $50 \operatorname{deg} 25.785^{\prime}$ & $5 / 24 / 0821: 00$ \\
\hline & G22 & N glacier stream outflow downstream at ADCP; turbid; $\mathrm{v}$. high flow & $68 \mathrm{deg} 02.601^{\prime}$ & $50 \operatorname{deg} 16.614^{\prime}$ & $5 / 25 / 2008$ \\
\hline & G23 & N glacier stream outflow at mouth; turbid; v. high flow & $68 \mathrm{deg} 02.623^{\prime}$ & $50 \operatorname{deg} 16.139^{\prime}$ & $5 / 25 / 2008$ \\
\hline & G24 & Stream flowing down side of $\mathrm{N}$ moraine & close to $\mathrm{N}$ mouth coordinates & close to $\mathrm{N}$ mouth coordinates & $5 / 25 / 2008$ \\
\hline & & Waterfall stream (draining Lake 240) (HOBO site) & $68 \mathrm{deg} 02.606^{\prime}$ & $50 \operatorname{deg} 17.055^{\prime}$ & $5 / 25 / 2008$ \\
\hline & $\mathrm{G} 26$ & Snow sample from N glacier surface (by supraglacial lake) & $68 \operatorname{deg} 02.739^{\prime}$ & $50 \operatorname{deg} 15.487^{\prime}$ & $5 / 22 / 2008$ \\
\hline & G26B & Replicate of G26 & $68 \operatorname{deg} 02.739^{\prime}$ & $50 \operatorname{deg} 15.487^{\prime}$ & $5 / 22 / 2008$ \\
\hline & G27 & composite sample of $5 / 24$ taken by autosampler at ADCP site & $68 \mathrm{deg} 02.601^{\prime}$ & $50 \operatorname{deg} 16.614^{\prime}$ & $5 / 24 / 2008$ \\
\hline & G28 & N glacier stream outflow downstream at ADCP; turbid & $68 \mathrm{deg} 02.601^{\prime}$ & $50 \mathrm{deg} 16.614^{\prime}$ & $5 / 26 / 2008$ \\
\hline & G29 & $\mathrm{N}$ glacier stream outflow at $\sim 2 \mathrm{~m}$ from mouth; turbid & $68 \mathrm{deg} 02.623^{\prime}$ & $50 \operatorname{deg} 16.139^{\prime}$ & $5 / 27 / 0814: 48$ \\
\hline & G29B & N glacier stream outflow at directly at mouth; turbid & $68 \operatorname{deg} 02.623^{\prime}$ & $50 \operatorname{deg} 16.139^{\prime}$ & $5 / 27 / 0814: 55$ \\
\hline & G29C & N glacier stream outflow at directly at mouth; turbid & $68 \mathrm{deg} 02.623^{\prime}$ & $50 \operatorname{deg} 16.139^{\prime}$ & $5 / 27 / 0814: 55$ \\
\hline & G30 & N glacier stream outflow downstream at ADCP; turbid & $68 \operatorname{deg} 02.601^{\prime}$ & $50 \operatorname{deg} 16.614^{\prime}$ & $5 / 27 / 0815: 50$ \\
\hline 32 & G31 & Waterfall stream (draining Lake 240) (HOBO site) & $68 \operatorname{deg} 02.606^{\prime}$ & $50 \operatorname{deg} 17.055^{\prime}$ & $5 / 27 / 0816: 00$ \\
\hline & $\mathrm{G} 32$ & Autosampler bottle 2 collected $5 / 25-\mathrm{N}$ stream at ADCP site & $68 \mathrm{deg} 02.601^{\prime}$ & $50 \operatorname{deg} 16.614^{\prime}$ & $5 / 25 / 0816: 00$ \\
\hline & G33 & Autosampler bottle 4 collected $5 / 26-\mathrm{N}$ stream at ADCP site & $68 \mathrm{deg} 02.601^{\prime}$ & $50 \operatorname{deg} 16.614^{\prime}$ & $5 / 26 / 0816: 00$ \\
\hline & & Autosampler bottle 5 collected $5 / 27$ - N stream at ADCP site & $68 \mathrm{deg} 02.601^{\prime}$ & $50 \operatorname{deg} 16.614^{\prime}$ & $5 / 27 / 0816: 00$ \\
\hline & G35 & North Margin M mouth (same site as G1) & $68 \operatorname{deg} 04.524^{4}$ & $50 \operatorname{deg} 19.754^{\prime}$ & $5 / 28 / 0816: 30$ \\
\hline 37 & G36 & $\mathrm{N}$ glacier stream outflow at mouth; turbid & $68 \mathrm{deg} 02.623^{\prime}$ & $50 \operatorname{deg} 16.139^{\prime}$ & $5 / 28 / 0810: 30$ \\
\hline 38 & G37 & M stream North floodplain just below marginal waterfall (HOBO site) & $68 \operatorname{deg} 04.219^{\prime}$ & $50 \operatorname{deg} 20.443^{\prime}$ & $5 / 28 / 2008$ \\
\hline & G38 & M stream South floodplain, rightside of penisula (HOBO site, but moved this $\mathrm{HOBO}$ to $\mathrm{N})$ & $68 \operatorname{deg} 03.655^{\prime}$ & $50 \operatorname{deg} 20.191^{\prime}$ & $5 / 28 / 2008$ \\
\hline & G39 & Push-point sample at M floodplain & M floodplain & M floodplain & $5 / 28 / 0819: 00$ \\
\hline & G40 & Swimming Pool Tarn & $68 \mathrm{deg} 02.831^{\prime}$ & $50 \operatorname{deg} 17.675^{\prime}$ & $5 / 29 / 0812: 40$ \\
\hline & G41 & Autosampler bottle collected $5 / 28$ - N stream at ADCP site & $68 \mathrm{deg} 02.601^{\prime}$ & $50 \operatorname{deg} 16.614^{\prime}$ & $5 / 29 / 0816: 00$ \\
\hline 43 & G42 & N glacier stream outflow at mouth; turbid & $68 \operatorname{deg} 02.623^{\prime}$ & $50 \operatorname{deg} 16.139^{\prime}$ & $5 / 29 / 0813: 41$ \\
\hline 44 & G43 & Ice Marginal Melt upstream of waterfall stream (feeds into waterfall stream) & $68 \operatorname{deg} 02.290^{\prime}$ & $50 \operatorname{deg} 15.236^{\prime}$ & $5 / 29 / 0816: 30$ \\
\hline & G44 & N glacier stream outflow downstream at ADCP; turbid & $68 \mathrm{deg} 02.601^{\prime}$ & $50 \operatorname{deg} 16.614^{\prime}$ & $5 / 29 / 08 \quad 11: 45$ \\
\hline & & Time-Series 1 - N glacier stream outflow at mouth; turbid & $68 \mathrm{deg} 02.623^{\prime}$ & $50 \operatorname{deg} 16.139^{\prime}$ & $5 / 30 / 0818: 00$ \\
\hline 47 & G46 & $\mathrm{N}$ glacier supraglacial (ice) meltwater at mouth; clear & $68 \operatorname{deg} 04.369^{\prime}$ & $50 \operatorname{deg} 26.921^{\prime}$ & $5 / 30 / 0818: 00$ \\
\hline 48 & G47 & Time-Series 2 - $\mathrm{N}$ glacier stream outflow at mouth; turbid; lower flow than time-series 1 & $68 \mathrm{deg} 02.623^{\prime}$ & $50 \operatorname{deg} 16.139^{\prime}$ & $5 / 31 / 080: 00$ \\
\hline 49 & G48 & Time-Series 3 - N glacier stream outflow at mouth; turbid & $68 \mathrm{deg} 02.623^{\prime}$ & $50 \operatorname{deg} 16.139^{\prime}$ & $5 / 31 / 086: 45$ \\
\hline & G49 & Time-Series 4 - N glacier stream outflow at mouth; turbid & $68 \operatorname{deg} 02.623^{\prime}$ & $50 \operatorname{deg} 16.139^{\prime}$ & $5 / 31 / 0812: 40$ \\
\hline & G50 & Supraglacial lake on N & $68 \operatorname{deg} 02.739^{\prime}$ & $50 \operatorname{deg} 15.487^{\prime}$ & $5 / 31 / 0816: 05$ \\
\hline & G51 & Time-Series 5 - N glacier stream outflow at mouth; turbid & $68 \mathrm{deg} 02.623^{\prime}$ & $50 \operatorname{deg} 16.139^{\prime}$ & $5 / 31 / 0818: 25$ \\
\hline & G52 & $\mathrm{N}$ glacier stream outflow at mouth; turbid & $68 \operatorname{deg} 02.623^{\prime}$ & $50 \operatorname{deg} 16.139^{\prime}$ & $6 / 1 / 2008$ \\
\hline 54 & G53 & Clark Lake & $68 \operatorname{deg} 03.096^{\prime}$ & $50 \operatorname{deg} 20.165^{\prime}$ & $6 / 1 / 2008$ \\
\hline $55 \mid$ & ICE & Ice & on surface of $\mathrm{N}$ ? & on surface of $\mathrm{N}$ ? & $\mathrm{NR}$ \\
\hline
\end{tabular}




\begin{tabular}{|c|c|c|c|c|c|}
\hline & Sample ID & Description & Latitude & Longitude & Collection Date \\
\hline & MiiliQ Blank 1 (May) & Field MQ blank & at camp & at camp & $6 / 1 / 2008$ \\
\hline & MilliQ Blank 2 (May) & Field MQ blank & at camp & at camp & $6 / 1 / 2008$ \\
\hline \multirow{2}{*}{\multicolumn{6}{|c|}{$\begin{array}{ll}38 \\
\text { Groundwater Samples }\end{array}$}} \\
\hline & & & & & \\
\hline & GM50 & $0.4 \mathrm{~m}$ depth at bank of adcp site & $68 \mathrm{deg} 02.601^{\prime}$ & $50 \operatorname{deg} 16.614^{\prime}$ & $5 / 25 / 0815: 00$ \\
\hline 60 & GM51 & $0.38 \mathrm{~m}$ depth, $100 \mathrm{~m}$ downstream & $68 \mathrm{deg} 02.601^{\prime}$ & $50 \mathrm{deg} 16.614^{\prime}$ & $5 / 25 / 0818: 40$ \\
\hline 61 & GM52 & $0.35 \mathrm{~m}$ depth, $100 \mathrm{~m}$ upstream from adcp & $68 \operatorname{deg} 02.601^{\prime}$ & $50 \operatorname{deg} 16.614^{\prime}$ & $5 / 25 / 0819: 00$ \\
\hline & GM53 & $0.42 \mathrm{~m}$ depth, $100 \mathrm{~m}$ upstream from gm 52 & $68 \operatorname{deg} 02.601^{\prime}$ & $50 \operatorname{deg} 16.614^{\prime}$ & $5 / 25 / 0819: 20$ \\
\hline & GM54 & $0.39 \mathrm{~m}$ depth, $100 \mathrm{~m}$ upstream from gm 53 & $68 \mathrm{deg} 02.601^{\prime}$ & $50 \operatorname{deg} 16.614^{\prime}$ & 5/25/08 19:30 \\
\hline \multicolumn{6}{|c|}{ July Samples } \\
\hline & G56 & N glacier stream outflow downstream at ADCP; turbid & $68 \mathrm{deg} 02.601^{\prime}$ & $50 \operatorname{deg} 16.614^{\prime}$ & $7 / 10 / 0811: 23$ \\
\hline 65 & G57 & N glacier stream outflow at mouth; turbid & $68 \operatorname{deg} 02.623^{\prime}$ & $50 \operatorname{deg} 16.139^{\prime}$ & 7/10/08 13:46 \\
\hline 66 & G58 & Waterfall stream (draining Lake 240) (HOBO site) & $68 \mathrm{deg} 02.606^{\prime}$ & $50 \operatorname{deg} 17.055^{\prime}$ & $7 / 10 / 0814: 40$ \\
\hline 67 & G59 & N glacier stream outflow at mouth (left side, fast flow); turbid & $68 \operatorname{deg} 02.623^{\prime}$ & $50 \operatorname{deg} 16.139^{\prime}$ & $7 / 11 / 0812: 30$ \\
\hline 68 & G60 & N glacier stream outflow at mouth (right side, slower flow); turbid & $68 \operatorname{deg} 02.623^{\prime}$ & $50 \operatorname{deg} 16.139^{\prime}$ & $7 / 11 / 0812: 30$ \\
\hline & Be/Ra-July & N glacier stream outflow downstream at ADCP; turbid; collected Be 50 gal; Ra cubi containers & $68 \mathrm{deg} 02.601^{\prime}$ & $50 \operatorname{deg} 16.614^{\prime}$ & $7 / 11 / 0816: 15$ \\
\hline & G61 & N glacier stream outflow at mouth time-series 1 (high flow); turbid & $68 \operatorname{deg} 02.623^{\prime}$ & $50 \operatorname{deg} 16.139^{\prime}$ & 7/11/08 18:00 \\
\hline 71 & G62 & N glacier stream outflow at mouth time-series 2 (v. low flow - ADCP exposed); turbid & $68 \operatorname{deg} 02.623^{\prime}$ & $50 \operatorname{deg} 16.139^{\prime}$ & $7 / 12 / 080: 00$ \\
\hline 72 & G63 & N glacier stream outflow at mouth time-series 3 (low flow); turbid & $68 \mathrm{deg} 02.623^{\prime}$ & $50 \operatorname{deg} 16.139^{\prime}$ & $7 / 12 / 086: 00$ \\
\hline 73 & G64 & N glacier stream outflow at mouth time-series 4; turbid & $68 \mathrm{deg} 02.623^{\prime}$ & $50 \operatorname{deg} 16.139^{\prime}$ & $7 / 12 / 0812: 50$ \\
\hline 74 & G65 & N glacier stream outflow at mouth time-series 5; turbid (low flow - ADCP exposed) & $68 \mathrm{deg} 02.623^{\prime}$ & $50 \operatorname{deg} 16.139^{\prime}$ & $7 / 12 / 0818: 00$ \\
\hline 75 & G66 & $\mathrm{N}$ glacier stream outflow at mouth (left side); turbid; very very low flow (overcast and foggy) & $68 \operatorname{deg} 02.623^{\prime}$ & $50 \operatorname{deg} 16.139^{\prime}$ & $7 / 13 / 0813: 50$ \\
\hline & G67 & Clark Lake (HOBO site) & $68 \operatorname{deg} 03.096^{\prime}$ & $50 \operatorname{deg} 20.165^{\prime}$ & $7 / 13 / 0818: 45$ \\
\hline 77 & G68 & $\mathrm{N}$ glacier stream outflow at mouth; turbid (sunny day) & $68 \operatorname{deg} 02.623^{\prime}$ & $50 \operatorname{deg} 16.139^{\prime}$ & 7/14/08 18:00 \\
\hline & G69 & $\mathrm{N}$ glacier stream outflow at mouth; turbid & $68 \operatorname{deg} 02.623^{\prime}$ & $50 \operatorname{deg} 16.139^{\prime}$ & $7 / 15 / 0816: 30$ \\
\hline & & North M subglacial stream (sampled downstream of mouth) (flow is high) & $68 \mathrm{deg} 04.525^{\prime}$ & $50 \operatorname{deg} 19.640^{\prime}$ & $7 / 15 / 0815: 24$ \\
\hline 80 & & N glacier stream outflow at mouth; turbid (flow is low, but not very very low) & $68 \mathrm{deg} 02.623^{\prime}$ & $50 \operatorname{deg} 16.139^{\prime}$ & $7 / 16 / 0822: 00$ \\
\hline 81 & G72 & Camp 2 Middle of Fjord (in subglacial plume) & $\mathrm{NM}$ & $\mathrm{NM}$ & $7 / 19 / 0820: 00$ \\
\hline 82 & G73 & Camp 2 Middle of Fjord & $68 \operatorname{deg} 55.433^{\prime}$ & $50 \operatorname{deg} 17.339^{\prime}$ & $7 / 22 / 080: 00$ \\
\hline 83 & G74 & Camp 2 subglacial input stream to fjord (stream nearest to camp) & $\mathrm{NM}$ & $\mathrm{NM}$ (b/c GPS in boat for $10 \mathrm{AU}$ transacts) & $7 / 24 / 0814: 15$ \\
\hline & G75 & Camp 2 Fjord water in subglacial plume from other fjord & $\mathrm{NM}$ & $\mathrm{NM}$ (b/c GPS in boat for $10 \mathrm{AU}$ transacts) & $7 / 24 / 0815: 00$ \\
\hline & G76 & Camp 2 at mouth of subglacial outflow to fjord (stream nearest to camp) (trace metals only) & NM & $\mathrm{NM}$ (b/c GPS in boat for $10 \mathrm{AU}$ transacts) & $7 / 24 / 0815: 00$ \\
\hline$\frac{05}{86}$ & G77 & Camp 2 ice from iceberg on shore of other fjord (O/D only) & $\mathrm{NM}$ & NM (b/c GPS in boat for $10 \mathrm{AU}$ transacts) & $7 / 24 / 0815: 00$ \\
\hline 87 & G78 & Camp 2 sediment plume farther from camp 2 at plume mouth where meets fjord water (taken from boat) & $\mathrm{NM}$ & $\mathrm{NM}$ (b/c GPS in boat for $10 \mathrm{AU}$ transacts) & $7 / 26 / 0811: 30$ \\
\hline 88 & G79 & Camp 2 sediment plume mouth into fjord (sed plume near camp 2) & NM & $\mathrm{NM}$ (b/c GPS in boat for $10 \mathrm{AU}$ transacts) & $7 / 26 / 0811: 40$ \\
\hline & G80 & Camp 2 ice sample from iceberg on shore of camp 2 side fjord & $\mathrm{NM}$ & $\mathrm{NM}$ (b/c GPS in boat for $10 \mathrm{AU}$ transacts) & $7 / 26 / 0812: 00$ \\
\hline \multicolumn{6}{|c|}{ June Autosampler Samples } \\
\hline & $\mathrm{A} 1$ & N glacier stream outflow downstream at ADCP; turbid & $68 \mathrm{deg} 02.601^{\prime}$ & $50 \mathrm{deg} 16.614^{\prime}$ & 6/1/08 16:00 \\
\hline 91 & $\mathrm{~A} 2$ & $\mathrm{~N}$ glacier stream outflow downstream at ADCP; turbid & $69 \mathrm{deg} 02.601^{\prime}$ & $51 \operatorname{deg} 16.614^{\prime}$ & $6 / 3 / 084: 00$ \\
\hline & Sample ID & Description & Latitude & Longitude & Collection Date \\
\hline 92 & $\mathrm{~A} 3$ & $\mathrm{~N}$ glacier stream outflow downstream at ADCP; turbid & $70 \operatorname{deg} 02.601^{\prime}$ & $52 \operatorname{deg} 16.614^{\prime}$ & $6 / 4 / 0816: 00$ \\
\hline 93 & A4 & N glacier stream outflow downstream at ADCP; turbid & $71 \operatorname{deg} 02.601^{\prime}$ & $53 \operatorname{deg} 16.614$ & $6 / 6 / 084: 00$ \\
\hline 94 & A5 & N glacier stream outflow downstream at ADCP; turbid & $72 \operatorname{deg} 02.601^{\prime}$ & $54 \operatorname{deg} 16.614^{\prime}$ & $6 / 7 / 0816: 00$ \\
\hline & A6 & N glacier stream outflow downstream at ADCP; turbid & $73 \operatorname{deg} 02.601^{\prime}$ & $55 \operatorname{deg} 16.614^{\prime}$ & 6/9/08 4:00 \\
\hline & A9 & N glacier stream outflow downstream at ADCP; turbid & $76 \operatorname{deg} 02.601^{\prime}$ & $58 \operatorname{deg} 16.614^{\prime}$ & 6/13/08 16:00 \\
\hline 97 & Al1 & N glacier stream outflow downstream at ADCP; turbid & $77 \operatorname{deg} 02.601^{\prime}$ & $59 \operatorname{deg} 16.614^{\prime}$ & 6/16/08 16:00 \\
\hline 98 & A12 & N glacier stream outflow downstream at ADCP; turbid & $78 \operatorname{deg} 02.601^{\prime}$ & $60 \operatorname{deg} 16.614^{\prime}$ & $6 / 18 / 084: 00$ \\
\hline 99 & $\mathrm{~A} 13$ & N glacier stream outflow downstream at ADCP; turbid & $79 \operatorname{deg} 02.601^{\prime}$ & $61 \operatorname{deg} 16.614^{\prime}$ & 6/19/08 16:00 \\
\hline 100 & $\mathrm{~A} 15$ & N glacier stream outflow downstream at ADCP; turbid & $80 \operatorname{deg} 02.601^{\prime}$ & $62 \operatorname{deg} 16.614^{\prime}$ & $6 / 22 / 0816: 00$ \\
\hline 101 & A17 & N glacier stream outflow downstream at ADCP; turbid & $81 \operatorname{deg} 02.601^{\prime}$ & $63 \operatorname{deg} 16.614^{\prime}$ & 6/25/08 16:00 \\
\hline 102 & A19 & $\mathrm{N}$ glacier stream outflow downstream at ADCP; turbid & $82 \operatorname{deg} 02.601^{\prime}$ & $64 \operatorname{deg} 16.614^{\prime}$ & 6/28/08 16:00 \\
\hline 103 & $\mathrm{~A} 21$ & N glacier stream outflow downstream at ADCP; turbid & $83 \operatorname{deg} 02.601^{\prime}$ & $65 \operatorname{deg} 16.614^{\prime}$ & $7 / 1 / 0816: 00$ \\
\hline 104 & $\mathrm{~A} 23$ & N glacier stream outflow downstream at ADCP; turbid & $84 \operatorname{deg} 02.601^{\prime}$ & $66 \operatorname{deg} 16.614^{\prime}$ & $7 / 4 / 0816: 00$ \\
\hline & & & & & \\
\hline & & & & & \\
\hline & & & & & \\
\hline
\end{tabular}




\begin{tabular}{|c|c|c|c|c|}
\hline \multicolumn{5}{|c|}{ Table A2: Greenland Ice Sheet Margins $2008 \mathrm{pH}, \mathrm{EC}$, Temperature } \\
\hline \multicolumn{5}{|c|}{\begin{tabular}{|l|l|l|l|} 
May Samples & & & \\
\end{tabular}} \\
\hline Sample ID & Sample Type & pH & EC $(\mu \mathrm{S} / \mathrm{cm}$, measured on-site $)$ & Temperature (degrees C, measured on-site) \\
\hline GM2 & MO & NM & $\mathrm{NM}$ & $\mathrm{NM}$ \\
\hline G1 & MO & 8.99 & 70.5 & assume just above freezing \\
\hline G2 & PW & 7.80 & 10.4 & assume just above freezing \\
\hline G3 & $\mathrm{NO}$ & 6.75 & 30 & 0.3 \\
\hline $\mathrm{G} 4$ & MI & 6.07 & 6 & 0.6 \\
\hline G5 & $\mathrm{NO}$ & 6.95 & 30.1 & 0.5 \\
\hline G6 & $\mathrm{NO}$ & 6.68 & 31.2 & 1 \\
\hline G7 & $\mathrm{PL}$ & 6.64 & 18.6 & 3.9 \\
\hline G8 & $\mathrm{NO}$ & 7.03 & 38.5 & 0.4 \\
\hline G9 & $\mathrm{NO}$ & 7.02 & 38.9 & 0.9 \\
\hline G10 & MF & 6.49 & NM & assume just above freezing \\
\hline G11 & $\mathrm{NO}$ & 7.68 & 41.8 & 0.3 \\
\hline G12 & $\mathrm{NO}$ & 6.86 & 144.3 & 0.3 \\
\hline G13 & $\mathrm{NO}$ & 6.63 & 45 & 0.8 \\
\hline G14 & MM & 6.83 & 11.5 & 2.5 \\
\hline G15 & MI & 9.25 & 0.4 & 1.1 \\
\hline G15B & MI & $\mathrm{N} / \mathrm{A}$ & $\mathrm{N} / \mathrm{A}$ & $\mathrm{N} / \mathrm{A}$ \\
\hline G16 & $\mathrm{NO}$ & 7.23 & NM & assume just above freezing \\
\hline G17 & $\mathrm{NO}$ & 6.90 & NM & assume just above freezing \\
\hline G18 & $\mathrm{NO}$ & 7.96 & NM & assume just above freezing \\
\hline G19 & $\mathrm{NO}$ & 7.17 & NM & assume just above freezing \\
\hline G20 & LO & 7.83 & 64.9 & 3.9 \\
\hline G21 & $\mathrm{OO}$ & 7.36 & 322 & 8.4 \\
\hline G22 & $\mathrm{NO}$ & 6.97 & 9.1 & 1.4 \\
\hline G23 & $\mathrm{NO}$ & 6.60 & 6.5 & 0.3 \\
\hline $\mathrm{G} 24$ & MM & 5.85 & 33 & 5 \\
\hline $\mathrm{G} 25$ & MM & 6.18 & 10.7 & 5.8 \\
\hline G26 & SN & 5.10 & NM & assume freezing \\
\hline G26B & SN & $\mathrm{N} / \mathrm{A}$ & $\mathrm{N} / \mathrm{A}$ & $\mathrm{N} / \mathrm{A}$ \\
\hline G27 & $\mathrm{NO}$ & 6.03 & NM & assume just above freezing \\
\hline G28 & $\mathrm{NO}$ & 6.72 & 12.9 & 0.9 \\
\hline G29 & $\mathrm{NO}$ & 7.21 & 15 & 0.7 \\
\hline G29B & $\mathrm{NO}$ & NM & 15 & 0.7 \\
\hline G29C & $\mathrm{NO}$ & NM & 15 & 0.7 \\
\hline G30 & $\mathrm{NO}$ & 6.61 & 17.1 & 1.5 \\
\hline G31 & MM & 6.20 & NM & assume just above freezing \\
\hline G32 & $\mathrm{NO}$ & 6.3 & NM & assume just above freezing \\
\hline G33 & $\mathrm{NO}$ & 6.21 & NM & assume just above freezing \\
\hline G34 & $\mathrm{NO}$ & 6.31 & NM & assume just above freezing \\
\hline G35 & MO & 7.03 & 22 & assume just above freezing \\
\hline G36 & $\mathrm{NO}$ & no & 23 & 1 \\
\hline G37 & MO & 7.33 & 22.2 & 3.4 \\
\hline G38 & MO & 6.15 & 5.7 & 2.6 \\
\hline G39 & GW & 6.08 & NM & \\
\hline G40 & $\mathrm{T}$ & 6.21 & NM & NM \\
\hline G41 & $\mathrm{NO}$ & 6.4 & NM & NM \\
\hline G42 & $\mathrm{NO}$ & 5.68 & 7.24 & 0.6 \\
\hline G43 & MM & 5.87 & 5.2 & 2.6 \\
\hline G44 & $\mathrm{NO}$ & 7.04 & 18.4 & 0.9 \\
\hline G45 & $\mathrm{NO}$ & 5.97 & 11.4 & 0.5 \\
\hline G46 & MI & 5.29 & 1.2 & 0.3 \\
\hline G47 & $\mathrm{NO}$ & 6.37 & 16.9 & 0.4 \\
\hline G48 & $\mathrm{NO}$ & 6.04 & 17.9 & 0.5 \\
\hline G49 & $\mathrm{NO}$ & 6.17 & 18.1 & 0.5 \\
\hline G50 & MI & 5.43 & 0.2 & 1.3 \\
\hline G51 & $\mathrm{NO}$ & 6.73 & 11 & 10.5 (measured at camp) \\
\hline G52 & $\mathrm{NO}$ & 6.27 & NM & NM \\
\hline G53 & PL & 6.13 & NM & NM \\
\hline$\overline{\text { ICE }}$ & MI & & NM & $\mathrm{NM}$ \\
\hline MilliQ Blank 1 (May) & $\mathrm{B}$ & & NM & $\mathrm{NM}$ \\
\hline MilliQ Blank 2 (May) & $\mathrm{B}$ & & NM & NM \\
\hline G55 & $\mathrm{NO}$ & & NM & NM \\
\hline \multicolumn{5}{|l|}{ Groundwater Samples } \\
\hline GM50 & GW & & NM & NM \\
\hline GM51 & GW & & NM & NM \\
\hline GM52 & GW & & NM & NM \\
\hline GM53 & GW & & NM & NM \\
\hline GM54 & GW & & NM & NM \\
\hline \multicolumn{5}{|l|}{ July Samples } \\
\hline G56 & $\mathrm{NO}$ & 6.21 & 1.5 & 1.2 \\
\hline G57 & $\mathrm{NO}$ & 6.01 & 1.2 & 0.2 \\
\hline G58 & MM & 6.08 & 4.6 & 1 \\
\hline G59 & $\mathrm{NO}$ & 7.4 & 1.6 & 0.5 \\
\hline G60 & $\mathrm{NO}$ & 6.84 & 3.1 & 0.4 \\
\hline Be/Ra-July & $\mathrm{NO}$ & NM & NM & NM \\
\hline G61 & $\mathrm{NO}$ & 6.45 & 1.1 & 0.4 \\
\hline G62 & $\mathrm{NO}$ & 5.94 & 2.1 & 0.3 \\
\hline
\end{tabular}




\begin{tabular}{|c|c|c|c|c|}
\hline Sample ID & Sample Type & pH & EC $(\mu \mathrm{S} / \mathrm{cm}$, measured on-site $)$ & T (degrees C, measured on-site) \\
\hline G63 & $\mathrm{NO}$ & 8 & 3.2 & 0.5 \\
\hline G64 & $\mathrm{NO}$ & 7.44 & 0.2 & 0.4 \\
\hline G65 & $\mathrm{NO}$ & 7.04 & 1.5 & 0.7 \\
\hline G66 & $\mathrm{NO}$ & 7.74 & 2.3 & 0.3 \\
\hline G67 & PL & 6.75 & 47.7 & 8.9 \\
\hline G68 & $\mathrm{NO}$ & 8.17 & 1.1 & 0.4 \\
\hline G69 & NO & 7.59 & 4.4 (measured at camp) & NM \\
\hline G70 & $\mathrm{MO}$ & 7.01 & te low & 0.9 \\
\hline G71 & $\mathrm{NO}$ & 6.44 & 2.3 & 0.3 \\
\hline G72 & $\mathrm{F}$ & 8.34 & 27.7 & 8.88 \\
\hline G73 & $\mathrm{F}$ & 8.28 & NM & NM \\
\hline G74 & SWF & 8.29 & 4.9 & 1.2 \\
\hline G75 & $\mathrm{F}$ & 7.63 & 30.6 & 4.7 \\
\hline G76 & SWF & NM & NM & NM \\
\hline G77 & IB & NM & NM & $\mathrm{NM}$ \\
\hline G78 & $\mathrm{F}$ & 8.22 & NM & NM \\
\hline G79 & SWF & 8.72 & 165.7 & 5.6 \\
\hline G80 & IB & 5.65 & NM & NM \\
\hline \multicolumn{5}{|c|}{\begin{tabular}{|l|} 
June Autosampler Samples \\
\end{tabular}} \\
\hline A1 & $\mathrm{NO}$ & NM & NM & NM \\
\hline A2 & $\mathrm{NO}$ & NM & NM & NM \\
\hline $\mathrm{A} 3$ & $\mathrm{NO}$ & NM & NM & NM \\
\hline A4 & $\mathrm{NO}$ & NM & NM & NM \\
\hline A5 & $\mathrm{NO}$ & NM & NM & NM \\
\hline A6 & $\mathrm{NO}$ & NM & NM & NM \\
\hline A9 & $\mathrm{NO}$ & NM & NM & NM \\
\hline A11 & $\mathrm{NO}$ & $\mathrm{NM}$ & NM & NM \\
\hline A12 & $\mathrm{NO}$ & NM & NM & NM \\
\hline A13 & $\mathrm{NO}$ & NM & NM & NM \\
\hline A15 & $\mathrm{NO}$ & NM & NM & NM \\
\hline A17 & $\mathrm{NO}$ & NM & NM & NM \\
\hline A19 & $\mathrm{NO}$ & NM & NM & NM \\
\hline $\mathrm{A} 21$ & $\mathrm{NO}$ & NM & NM & NM \\
\hline A23 & $\mathrm{NO}$ & NM & NM & NM \\
\hline
\end{tabular}




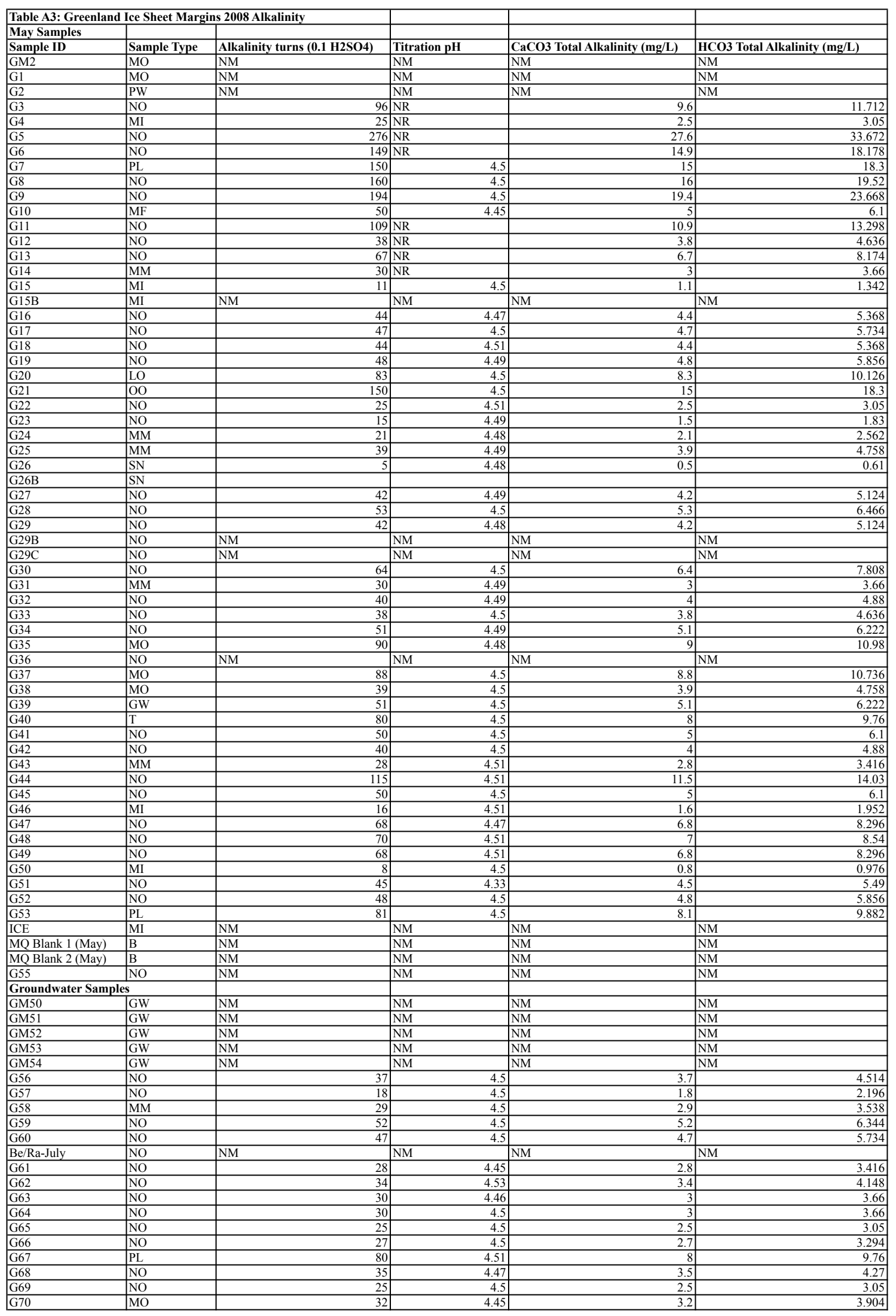




\begin{tabular}{|c|c|c|c|c|c|}
\hline Sample ID & Sample Type & \begin{tabular}{|l} 
Alkalinity turns (0.1 H2SO4) \\
\end{tabular} & Titration pH & CaCO3 Total Alkalinity (mg/L) & HCO3 Total Alkalinity (mg/L) \\
\hline \multicolumn{6}{|c|}{\begin{tabular}{|l|} 
July Samples \\
\end{tabular}} \\
\hline G71 & NO & 25 & 4.5 & 2.5 & 3.05 \\
\hline G72 & $\mathrm{F}$ & 690 & 4.48 & 69 & 84.18 \\
\hline G73 & F & 695 & \begin{tabular}{c|c}
4.45 \\
\end{tabular} & 69.5 & 84.79 \\
\hline $\mathrm{G} 74$ & SWF & 48 & 4.51 & 4.8 & 5.856 \\
\hline G75 & $\mathrm{F}$ & 580 & 4.51 & 58 & 70.76 \\
\hline G76 & SWF & NM & NM & NM & NM \\
\hline G77 & IB & NM & NM & NM & NM \\
\hline G78 & $\mathrm{F}$ & 301 & 4.3 & 30.1 & 36.722 \\
\hline G79 & SWF & 54 & 4.53 & 5.4 & 6.588 \\
\hline G80 & IB & 13 & 4.47 & 1.3 & 1.586 \\
\hline \multicolumn{6}{|c|}{\begin{tabular}{|l|} 
June Autosampler Samples \\
\end{tabular}} \\
\hline $\mathrm{A} 1$ & $\mathrm{NO}$ & NM & NM & NM & NM \\
\hline$\overline{\mathrm{A} 2}$ & $\mathrm{NO}$ & NM & NM & NM & NM \\
\hline A3 & NO & NM & NM & NM & NM \\
\hline$\overline{\mathrm{A} 4}$ & $\mathrm{NO}$ & NM & NM & NM & NM \\
\hline A5 & $\mathrm{NO}$ & $\mathrm{NM}$ & NM & NM & NM \\
\hline \begin{tabular}{|l|} 
A6 \\
\end{tabular} & $\mathrm{NO}$ & NM & NM & NM & NM \\
\hline \begin{tabular}{|l|} 
A99 \\
\end{tabular} & $\mathrm{NO}$ & $\mathrm{NM}$ & NM & NM & NM \\
\hline \begin{tabular}{|l|l} 
A11 \\
\end{tabular} & NO & NM & NM & NM & NM \\
\hline A12 & NO & NM & NM & NM & NM \\
\hline A13 & NO & NM & NM & NM & NM \\
\hline \begin{tabular}{|l|}
$\mathrm{A} 15$ \\
\end{tabular} & $\mathrm{NO}$ & NM & NM & NM & NM \\
\hline \begin{tabular}{|l} 
A17 \\
\end{tabular} & NO & NM & NM & NM & NM \\
\hline \begin{tabular}{|l|}
$\mathrm{A} 19$ \\
\end{tabular} & $\mathrm{NO}$ & NM & NM & NM & NM \\
\hline \begin{tabular}{|l|}
$\mathrm{A} 21$ \\
\end{tabular} & $\mathrm{NO}$ & NM & NM & NM & NM \\
\hline \begin{tabular}{|l}
$\mathrm{A} 23$ \\
\end{tabular} & $\mathrm{NO}$ & NM & NM & NM & NM \\
\hline
\end{tabular}




\begin{tabular}{|c|c|c|c|c|c|c|c|}
\hline \multicolumn{7}{|c|}{ Table A4: Greenland Ice Sheet Inland and Margins Electrical Conductivity (EC), Radon (Rn)-222, Beryllium (Be)-7, Oxygen Isotopes } & \multirow[b]{2}{*}{ SD VSMOW } \\
\hline Sample ID & Sample Type & Collection Date & EC $(\mu \mathrm{S} / \mathrm{cm}$, measured on-site $)$ & $\operatorname{Rn}(d p m / L)$ & $\mathrm{Be}(\mathrm{dpm} / \mathrm{L})$ & \$180 VSMOW & \\
\hline GM2 & MO & 5/17/08 12:30 & & 4.282851021 & & & \\
\hline G1 & MO & $5 / 17 / 0813: 55$ & 70.5 & 57.47262441 & & -27.28 & -201.13 \\
\hline G2 & PW & 5/17/08 16:04 & 10.4 & 4.124877306 & & -17.16 & -132.63 \\
\hline G3 & NO & 5/18/08 14:20 & 30 & 103.3624792 & & -25.25 & -191.33 \\
\hline G4 & MI & $\begin{array}{ll}5 / 18 / 08 ~ 14: 20 \\
\end{array}$ & 6 & 0 & & -29.54 & -227.22 \\
\hline G5 & NO & \begin{tabular}{|l|l|}
$5 / 19 / 08$ & $12: 41$ \\
\end{tabular} & 30.1 & & & -25 & -189.93 \\
\hline G6 & NO & \begin{tabular}{|l|l|}
$5 / 19 / 08$ & $13: 55$ \\
\end{tabular} & 31.2 & 4.054964086 & & -24.97 & -189.62 \\
\hline G7 & PL & 5/20/08 14:05 & 18.6 & 25.17975174 & 0.03 & -21.12 & -162.6 \\
\hline G8 & NO & $5 / 20 / 0816: 00$ & 38.5 & & & -24.21 & -180.3 \\
\hline G9 & NO & $\begin{array}{ll}5 / 20 / 08 & 16: 30\end{array}$ & 38.9 & 0 & & -24.04 & -178.99 \\
\hline G10 & MF & 5/20/08 16:30 & & & & -26.01 & -195.65 \\
\hline G11 & NO & \begin{tabular}{|l|l}
$5 / 21 / 0814: 23$ \\
\end{tabular} & 41.8 & 143.24 & & -23.82 & -178.96 \\
\hline \begin{tabular}{|l|} 
G12 \\
\end{tabular} & NO & $5 / 21 / 0814: 10$ & 144.3 & 8.063867255 & & -21.49 & -164.63 \\
\hline \begin{tabular}{|l|} 
G13 \\
\end{tabular} & NO & $5 / 21 / 08 \quad 16: 25$ & 45 & & 1.05 & -23.3 & -177.23 \\
\hline \begin{tabular}{|l|} 
G14 \\
\end{tabular} & MM & $5 / 21 / 08$ & 11.5 & & & -26.29 & -204.99 \\
\hline G15 & MI & \begin{tabular}{l|l}
$5 / 22 / 08 ~ 17: 00$ \\
\end{tabular} & 0.4 & 0 & 7.68 & -28.23 & -216.05 \\
\hline G15B & MI & $5 / 22 / 08$ 17:00 & & & & & \\
\hline G16 & $\mathrm{NO}$ & \begin{tabular}{l|l}
$5 / 22 / 08 ~ 18: 00$ \\
\end{tabular} & & 209.5031227 & & -25.02 & -187.81 \\
\hline \begin{tabular}{|l|} 
G17 \\
\end{tabular} & NO & $5 / 22 / 08 \quad 18: 10$ & & 12.14304544 & & -25.94 & -196.46 \\
\hline G18 & NO & \begin{tabular}{|l|}
$5 / 23 / 08 ~ 13: 45$ \\
\end{tabular} & & \begin{tabular}{l|}
7.856164195 \\
\end{tabular} & & -26.31 & -198.7 \\
\hline \begin{tabular}{|l|l|} 
G19 \\
\end{tabular} & NO & $5 / 23 / 0817: 00$ & & 151.3936591 & & -26.18 & -198.51 \\
\hline G20 & LO & $\begin{array}{ll}5 / 24 / 08 & 19: 00\end{array}$ & 64.9 & 3.473167231 & & -25.52 & -194.54 \\
\hline G21 & $\mathrm{OO}$ & 5/24/08 21:00 & 322 & 6.6491856 & & -26.25 & -195.73 \\
\hline G22 & NO & $5 / 25 / 08$ & 9.1 & & & -26.35 & -198.85 \\
\hline G23 & NO & $5 / 25 / 08$ & 6.5 & & & -26.93 & -206.27 \\
\hline G24 & MM & $5 / 25 / 08$ & 33 & & & & \\
\hline G25 & MM & $5 / 25 / 08$ & 10.7 & & & -26.93 & -205.94 \\
\hline \begin{tabular}{|l|} 
G26 \\
\end{tabular} & SN & $5 / 22 / 08$ & & & & -12.33 & -89.9 \\
\hline G26B & \begin{tabular}{|l|l|} 
SN \\
\end{tabular} & 5/22/08 & & & & & \\
\hline G27 & NO & $5 / 24 / 08$ & & & & -25.51 & -193.54 \\
\hline G28 & NO & 5/26/08 & 12.9 & & & -26.24 & -199.83 \\
\hline \begin{tabular}{|l|} 
G29 \\
\end{tabular} & NO & 5/27/08 14:48 & 15 & 29.63092664 & & -26.04 & -195.86 \\
\hline G29B & NO & 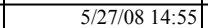 & 15 & 39.36607883 & & -26.04 & -195.86 \\
\hline G29C & NO & \begin{tabular}{|l|}
$5 / 27 / 0814: 55$ \\
\end{tabular} & 15 & 39.6198509 & & & \\
\hline G30 & NO & \begin{tabular}{l|}
$5 / 27 / 0815: 50$ \\
\end{tabular} & 17.1 & & & -26.38 & -198.92 \\
\hline \begin{tabular}{|l|} 
G31 \\
\end{tabular} & MM & $5 / 27 / 0816: 00$ & & & & -26.18 & -199.15 \\
\hline G32 & NO & $5 / 25 / 08 \quad 16: 00$ & & & & -25.96 & -195.44 \\
\hline \begin{tabular}{|l|l|} 
G33 \\
\end{tabular} & NO & $5 / 26 / 08 \quad 16: 00$ & & & & -25.41 & -194.32 \\
\hline G34 & NO & $5 / 27 / 08 \quad 16: 00$ & & & & -26.18 & -198.09 \\
\hline \begin{tabular}{|l|} 
G35 \\
\end{tabular} & MO & $5 / 28 / 0816: 30$ & 22 & 36.81513609 & 0.25 & -25.11 & -188.27 \\
\hline G36 & NO & 5/28/08 10:30 & 23 & 59.20957369 & & & \\
\hline \begin{tabular}{|l|l|} 
G37 \\
\end{tabular} & MO & $5 / 28 / 08$ & 22.2 & & & -24.47 & $-185,77$ \\
\hline \begin{tabular}{|l|l|} 
G38 \\
\end{tabular} & MO & $5 / 28 / 08$ & 5.7 & & & -30.95 & -236.28 \\
\hline \begin{tabular}{|l|} 
G39 \\
\end{tabular} & GW & $5 / 28 / 08 \quad 19: 00$ & & \begin{tabular}{|l|}
1625.770623 \\
\end{tabular} & & -27.86 & -209.2 \\
\hline G40 & T & $5 / 29 / 08 \quad 12: 40$ & & & & -13.34 & -116.26 \\
\hline G41 & NO & \begin{tabular}{l|l}
$5 / 29 / 08$ & $16: 00$
\end{tabular} & & & & -26.07 & -195.13 \\
\hline G42 & NO & 5/29/08 13:41 & 7.24 & 25.0166977 & & -25.7 & -194.95 \\
\hline \begin{tabular}{|l|l}
$\mathrm{G} 42$ \\
$\mathrm{G} 43$
\end{tabular} & MM & 5/29/08 16:30 & $\begin{array}{r}1.24 \\
5.2\end{array}$ & & & -26.15 & -198.11 \\
\hline G44 & NO & \begin{tabular}{|l|l|l}
$5 / 29 / 08$ & $11: 45$
\end{tabular} & 18.4 & & & -25.04 & -186.88 \\
\hline G45 & NO & \begin{tabular}{l|}
$5 / 30 / 08 ~ 18: 00$ \\
\end{tabular} & 11.4 & 38.29948513 & & -25.2 & -189.97 \\
\hline \begin{tabular}{|l|} 
G466 \\
\end{tabular} & MI & 5/30/08 $18: 00$ & 1.2 & & & -29.58 & -223.16 \\
\hline \begin{tabular}{|l|} 
G47 \\
\end{tabular} & NO & $5 / 31 / 080: 00$ & 16.9 & 60.75008104 & & -24.4 & -187.52 \\
\hline G48 & NO & $5 / 31 / 086: 45$ & 17.9 & 75.4874663 & & -25.05 & -184.47 \\
\hline G49 & NO & $5 / 31 / 08 \quad 12: 40$ & 18.1 & 49.352666 & & -24.82 & -187.87 \\
\hline \begin{tabular}{|l|} 
G50 \\
\end{tabular} & MI & $5 / 31 / 0816: 05$ & 0.2 & 0 & & -27.48 & -212.05 \\
\hline G51 & NO & 5/31/08 $18: 25$ & 11 & 47.53239899 & & -25.77 & -197.04 \\
\hline \begin{tabular}{|l|} 
G52 \\
\end{tabular} & NO & 6/1/08 & & & & -25.81 & -197.78 \\
\hline \begin{tabular}{|l|} 
G53 \\
\end{tabular} & PL & \begin{tabular}{l|}
$6 / 1 / 08$ \\
\end{tabular} & & \begin{tabular}{|l|}
4.977991376 \\
\end{tabular} & & -26.3 & -201.24 \\
\hline ICE & MI & $\begin{array}{ll}6 / 1 / 08 \\
\end{array}$ & & & & -28.77 & -220.34 \\
\hline MilliQ Blank 1 (May) & $\mathrm{B}$ & \begin{tabular}{l|}
$6 / 1 / 08$ \\
\end{tabular} & & & & & \\
\hline MilliQ Blank 2 (May) & B & \begin{tabular}{l|}
$6 / 1 / 08$ \\
\end{tabular} & & & & & \\
\hline G55 & NO & $5 / 25 / 08 \quad 19: 36$ & & 16.85986518 & & & \\
\hline GM50 & GW & 5/25/08 15:00 & & 2746.000888 & & & \\
\hline \begin{tabular}{|l} 
GM51 \\
\end{tabular} & GW & $5 / 25 / 0818: 40$ & & & & & \\
\hline GM52 & GW & 5/25/08 19:00 & & & & & \\
\hline \begin{tabular}{|l|} 
GM53 \\
\end{tabular} & GW & $5 / 25 / 0819: 20$ & & & & & \\
\hline GM54 & GW & 5/25/08 19:30 & & & & & \\
\hline A1 & NO & $6 / 1 / 0816: 00$ & & & & -27.55 & -205.2 \\
\hline A2 & NO & 6/3/08 4:00 & & & & -25.89 & -192.13 \\
\hline $\mathrm{A} 3$ & NO & 6/4/08 16:00 & & & & -27.46 & -206.29 \\
\hline A4 & NO & 6/6/08 4:00 & & & & -26.28 & -196.34 \\
\hline A5 & NO & 6/7/08 16:00 & & & & -27.57 & -205.52 \\
\hline A6 & NO & 6/9/08 4:00 & & & & -26.38 & -197.75 \\
\hline A9 & NO & 6/13/08 16:00 & & & & -27.16 & -202.94 \\
\hline A11 & NO & 6/16/08 16:00 & & & & -27.34 & -206.52 \\
\hline A12 & NO & 6/18/08 4:00 & & & & -25.64 & -191.88 \\
\hline A13 & NO & 6/19/08 16:00 & & & & -26.9 & -202.17 \\
\hline A15 & NO & 6/22/08 16:00 & & & & -27.65 & -209.8 \\
\hline A17 & NO & $6 / 25 / 0816: 00$ & & & & -27.92 & -211.11 \\
\hline A19 & NO & 6/28/08 16:00 & & & & -28.02 & -212.26 \\
\hline $\mathrm{A} 21$ & NO & 7/1/08 16:00 & & & & -28.18 & -212.3 \\
\hline A23 & NO & 7/4/08 16:00 & & & & -27.65 & -211.74 \\
\hline G56 & NO & $7 / 10 / 0811: 23$ & 1.5 & 4.598422349 & & -27.73 & -209.19 \\
\hline \begin{tabular}{|l|} 
G57 \\
\end{tabular} & NO & $7 / 10 / 08$ 13:46 & 1.2 & 16.73899485 & & -28.06 & -211 \\
\hline
\end{tabular}




\begin{tabular}{|c|c|c|c|c|c|c|c|}
\hline Sample ID & Sample Type & Collection Date & EC $(\mu \mathrm{S} / \mathrm{cm}$, measured on-site $)$ & $\operatorname{Rn}(\mathrm{dpm} / \mathrm{L})$ & $\mathrm{Be}(\mathrm{dpm} / \mathrm{L})$ & \$180 VSMOW & SD VSMOW \\
\hline G58 & MM & $7 / 10 / 0814: 40$ & 4.6 & 6.094806167 & & -28.28 & -216.82 \\
\hline \begin{tabular}{|l|l|l} 
G59 \\
\end{tabular} & NO & $7 / 11 / 0812: 30$ & 1.6 & 20.33389511 & & -27.91 & -213.87 \\
\hline G60 & NO & $7 / 11 / 0812: 30$ & 3.1 & 10.22925312 & & -30.03 & -230.26 \\
\hline Be/Ra-July & NO & $7 / 11 / 0816: 15$ & & & 0.03 & & \\
\hline G61 & NO & 7/11/08 18:00 & 1.1 & 29.64785695 & & -27.66 & -211.86 \\
\hline G62 & NO & $7 / 12 / 080: 00$ & 2.1 & 30.13613837 & & -27.16 & -207.85 \\
\hline G63 & NO & 7/12/08 6:00 & 3.2 & 30.09828272 & & -27 & -207.24 \\
\hline G64 & NO & $7 / 12 / 0812: 50$ & 0.2 & 31.78619897 & & -26.78 & -206.82 \\
\hline G65 & NO & $7 / 12 / 0818: 00$ & 1.5 & 27.26997413 & & -27.37 & -209.7 \\
\hline G66 & NO & $7 / 13 / 0813: 50$ & 2.3 & 35.6503304 & & -27.06 & -206.45 \\
\hline G67 & PL & $7 / 13 / 0818: 45$ & 47.7 & 8.879711842 & & -27.01 & -201.02 \\
\hline G68 & NO & 7/14/08 18:00 & 1.1 & 10.37656762 & & -28.36 & -209.75 \\
\hline G69 & NO & $7 / 15 / 08 \quad 16: 30$ & 4.4 & 23.68743661 & & -28.11 & -211.83 \\
\hline G70 & MO & $7 / 15 / 0815: 24$ & 2.4 & 13.52256843 & & -28.52 & -213.43 \\
\hline G71 & NO & 7/16/08 22:00 & 2.3 & 23.39667411 & & -28.17 & -208.27 \\
\hline G72 & $\mathrm{F}$ & 7/19/08 20:00 & 27.7 & 0 & & -10.34 & -80.83 \\
\hline G73 & $\mathrm{F}$ & $7 / 22 / 080: 00$ & & 0 & & -10.49 & -80.09 \\
\hline G74 & SWF & $\begin{array}{ll}7 / 24 / 0814: 15 \\
\end{array}$ & 4.9 & 0 & & -35.36 & -264.31 \\
\hline G75 & $\mathrm{F}$ & $7 / 24 / 0815: 00$ & 30.6 & 5.896462404 & & -13.71 & -109.45 \\
\hline $\mathrm{G} 76$ & SWF & 7/24/08 15:00 & & & & & \\
\hline G77 & IB & 7/24/08 15:00 & & & & -33.16 & -252.3 \\
\hline G78 & F & $7 / 26 / 0811: 30$ & & 5.994280542 & & -24.68 & -189.14 \\
\hline G79 & SWF & $7 / 26 / 0811: 40$ & 165.7 & 6.098600106 & & -33.64 & -252.92 \\
\hline G80 & IB & $7 / 26 / 0812: 00$ & & & & -30.81 & -228.58 \\
\hline \multicolumn{8}{|c|}{\begin{tabular}{|l|} 
Inland Supraglacial Samples \\
\end{tabular}} \\
\hline North Lake stream & NLS & $7 / 20 / 08$ & & & 0.04 & & \\
\hline L15 & NLI & $7 / 20 / 07$ & & & & -24.6 & -186.3 \\
\hline L16 & NLI & $7 / 20 / 07$ & & & & -26.5 & -202.6 \\
\hline L17 & NLI & $7 / 20 / 07$ & & & & -24.4 & -186.3 \\
\hline L18 & NCY & $7 / 20 / 07$ & & & & -26.1 & -199.5 \\
\hline L19 & NCY & $7 / 20 / 07$ & & & & -25.4 & -193.1 \\
\hline $\mathrm{L} 20$ & NCY & $7 / 20 / 07$ & & & & -25.6 & -195.5 \\
\hline $\mathrm{L} 21$ & NCY & \begin{tabular}{|c|}
$7 / 20 / 07$ \\
\end{tabular} & & & & -25.2 & $\begin{array}{l}-192.8 \\
\end{array}$ \\
\hline L22 & NCY & \begin{tabular}{|c|}
$7 / 20 / 07$ \\
\end{tabular} & & & & -25.3 & \begin{tabular}{|l|l|}
-194.7 \\
\end{tabular} \\
\hline L23 & NLS & \begin{tabular}{|c|}
$7 / 20 / 07$ \\
\end{tabular} & & & & -24.4 & \begin{tabular}{|l|}
-186.2 \\
\end{tabular} \\
\hline \begin{tabular}{|l|} 
L24 \\
\end{tabular} & NNLW & $7 / 20 / 07$ & & & & -25.1 & $\begin{array}{l}-191.6 \\
\end{array}$ \\
\hline L5 & \begin{tabular}{|l|l|} 
SLLI \\
\end{tabular} & $7 / 13 / 07$ & & & & -23.3 & $\begin{array}{l}-176.8 \\
\end{array}$ \\
\hline L6 & SLLI & \begin{tabular}{|c|}
$7 / 13 / 07$ \\
\end{tabular} & & & & -23.4 & -176.9 \\
\hline L7 & SLLI & 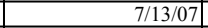 & & & & -26.3 & $\begin{array}{l}-198.7 \\
\end{array}$ \\
\hline \begin{tabular}{|l|} 
L8 \\
\end{tabular} & SLI & $7 / 17 / 07$ & & & & -24.8 & $\begin{array}{l}-187.9 \\
\end{array}$ \\
\hline \begin{tabular}{|l|} 
L9 \\
\end{tabular} & SLI & 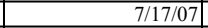 & & & & -25.1 & $\begin{array}{l}-189.5 \\
\end{array}$ \\
\hline $\begin{array}{ll}\text { L10 } \\
\end{array}$ & SLI & \begin{tabular}{|c|}
$7 / 17 / 07$ \\
\end{tabular} & & & & -24.1 & $\begin{array}{l}-183.5 \\
\end{array}$ \\
\hline \begin{tabular}{|l|} 
L11 \\
\end{tabular} & SCY & 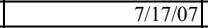 & & & & -22.6 & \begin{tabular}{|l|l}
-171.1 \\
\end{tabular} \\
\hline \begin{tabular}{|l|} 
L12 \\
\end{tabular} & SCY & $7 / 17 / 07$ & & & & -22.7 & -171.5 \\
\hline \begin{tabular}{|l|} 
L13 \\
\end{tabular} & SLW & 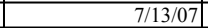 & & & & -24.1 & \begin{tabular}{|l|}
-183.8 \\
\end{tabular} \\
\hline L14 & SLW & \begin{tabular}{|c|}
$7 / 13 / 07$ \\
\end{tabular} & & & & -24.1 & -184 \\
\hline L1 & SLSNF & 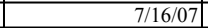 & & & & -21.5 & \begin{tabular}{|l|}
-162.1 \\
\end{tabular} \\
\hline L2 & SLSNF & $7 / 16 / 07$ & & & & -21.9 & -164.4 \\
\hline L3 & SLSNF & \begin{tabular}{|c|}
$7 / 17 / 07$ \\
\end{tabular} & & & & -20.3 & \begin{tabular}{|l|}
-154.9 \\
\end{tabular} \\
\hline L4 & NLSNF & $7 / 20 / 07$ & & & & -21.4 & $\begin{array}{l}-161.2 \\
\end{array}$ \\
\hline \begin{tabular}{|l|}
$\mathrm{L} 25$ \\
\end{tabular} & RMI & $7 / 26 / 07$ & & & & -27.4 & -211.9 \\
\hline \begin{tabular}{|l|} 
L27 \\
\end{tabular} & RMI & $7 / 26 / 07$ & & & & -27.4 & -212.5 \\
\hline \begin{tabular}{|l|} 
L26 \\
\end{tabular} & RMI & $7 / 26 / 07$ & & & & -27.4 & $\begin{array}{l}-213.2 \\
\end{array}$ \\
\hline \begin{tabular}{|l|} 
L28 \\
\end{tabular} & RPW & $7 / 26 / 07$ & & & & -25.8 & $\begin{array}{l}-201.3 \\
\end{array}$ \\
\hline \begin{tabular}{|l|} 
L29 \\
\end{tabular} & RPW & $7 / 26 / 07$ & & & & -26.9 & -206.5 \\
\hline \multicolumn{8}{|l|}{\begin{tabular}{|l|} 
Other Samples \\
\end{tabular}} \\
\hline Plymouth pond rain water & PPR & $4 / 28 / 08$ & & & 4.6 & & \\
\hline & & & & & & & \\
\hline & & & & & & & \\
\hline & & & & & & & \\
\hline & & & & & & & \\
\hline & & & & & & & \\
\hline & & & & & & & \\
\hline & & & & & & & \\
\hline & & & & & & & \\
\hline & & & & & & & \\
\hline & & & & & & & \\
\hline & & & & & & & \\
\hline
\end{tabular}




\begin{tabular}{|c|c|c|c|c|c|c|c|c|c|}
\hline Table & Ice Sheet & rient & & & & & & & \\
\hline & Sample ID & Collection Date & Sample Type & $\mu \mathrm{M}$ NH4 & $\mu \mathrm{M}$ Silicate & $\mu \mathrm{M} \mathrm{PO4}$ & $\mu \mathrm{M}$ NO2+NO3 & $\mu M$ DIN & $\mu M$ DON \\
\hline & GM2 & $5 / 17 / 08 \quad 12: 30$ & MO & $\mathrm{NaN}$ & $\mathrm{NaN}$ & $\mathrm{NaN}$ & $\mathrm{NaN}$ & $\mathrm{NaN}$ & $\mathrm{NaN}$ \\
\hline & G1 & $5 / 17 / 0813: 55$ & MO & 1.47404 & 51.28873 & 0.07608 & 1.74656 & 3.22060 & 11.30538 \\
\hline & 3 & 5/17/08 16:04 & PW & 0.42202 & 8.41504 & 0.08676 & 0.06852 & 0.49054 & 10.86533 \\
\hline & $4 \mathrm{G3}$ & $5 / 18 / 0814: 20$ & $\mathrm{NO}$ & 1.16106 & 13.92269 & 0.08491 & 0.82057 & 1.98163 & 8.42320 \\
\hline & 5 & $5 / 18 / 08 \quad 14: 20$ & MI & 1.36298 & 7.89294 & $\mathrm{NaN}$ & 0.57047 & 1.93345 & 9.42241 \\
\hline & G4-TOC-DOC $(0.3 \mathrm{um})$ & 5/18/08 14:20 & MI & & & & & & \\
\hline & 6 G5 & 5/19/08 12:41 & $\mathrm{NO}$ & 1.43365 & 17.09624 & $\mathrm{NaN}$ & 3.05907 & 4.49272 & $\mathrm{NaN}$ \\
\hline & G5-TOC-DOC (0.3 um) & 5/19/08 12:41 & $\mathrm{NO}$ & & & & & & \\
\hline & $\begin{array}{l}7 \mathrm{G} 6 \\
\end{array}$ & 5/19/08 13:55 & $\mathrm{NO}$ & 0.96519 & 21.70302 & 0.09231 & 1.77757 & 2.74276 & 11.14920 \\
\hline & G6-TOC-DOC (0.3 um) & 5/19/08 13:55 & $\mathrm{NO}$ & & & & & & \\
\hline & \begin{tabular}{|l|l|l|}
8 & G7 \\
\end{tabular} & 5/20/08 14:05 & PL & 0.19687 & 8.28195 & 0.08933 & 0.22013 & 0.41700 & 21.71725 \\
\hline & $\begin{array}{ll}9 \mathrm{G} 8 \\
\end{array}$ & $5 / 20 / 08 \quad 16: 00$ & NO & 1.18125 & 15.76540 & $\mathrm{NaN}$ & 1.34351 & 2.52476 & 17.39042 \\
\hline 10 & G9 & $5 / 20 / 0816: 30$ & $\mathrm{NO}$ & 0.53610 & 19.14370 & $\mathrm{NaN}$ & 4.35090 & 4.88701 & 6.15184 \\
\hline 11 & \begin{tabular}{l|l}
1 & G10
\end{tabular} & $5 / 20 / 0816: 30$ & MF & 0.20394 & 11.67049 & $\mathrm{NaN}$ & 2.44932 & 2.65326 & 19.79801 \\
\hline 12 & 2 G11 & $5 / 21 / 0814: 23$ & $\mathrm{NO}$ & 1.10048 & 27.74301 & $\mathrm{NaN}$ & 3.29677 & 4.39724 & 10.44575 \\
\hline 13 & 3 & 5/21/08 14:10 & $\mathrm{NO}$ & 4.17980 & 45.35112 & 0.07875 & 20.87607 & 25.05587 & 22.43931 \\
\hline & G12-TOC-DOC $(0.3 \mathrm{um})$ & $5 / 21 / 08 \quad 14: 10$ & $\mathrm{NO}$ & & & & & & \\
\hline 14 & \begin{tabular}{|l|l|} 
G13 \\
\end{tabular} & 5/21/08 16:25 & $\mathrm{NO}$ & 1.84759 & 20.06505 & 0.08081 & 5.41538 & 7.26297 & 12.65221 \\
\hline 15 & 5 & $5 / 21 / 08$ & MM & 0.05563 & 16.17489 & 0.10781 & 0.36171 & 0.41734 & 14.74266 \\
\hline 16 & G15 & 5/22/08 17:00 & MI & 1.21154 & 5.86596 & 0.11089 & 0.36688 & 1.57842 & 9.46044 \\
\hline & G15B & $5 / 22 / 08 \quad 17: 00$ & MI & & & & & & \\
\hline 17 & 7 & 5/22/08 18:00 & $\mathrm{NO}$ & 0.75721 & 40.94909 & $\mathrm{NaN}$ & 2.99706 & 3.75427 & 7.28458 \\
\hline 18 & G17 & $5 / 22 / 0818: 10$ & $\mathrm{NO}$ & 0.84202 & 17.30099 & 0.43843 & 4.78496 & 5.62698 & 15.55624 \\
\hline 19 & \begin{tabular}{|l|l|}
9 & G18
\end{tabular} & $5 / 23 / 0813: 45$ & $\mathrm{NO}$ & 1.33269 & 32.04266 & $\mathrm{NaN}$ & 4.87797 & 6.21066 & 9.26635 \\
\hline 20 & G19 & $5 / 23 / 08 \quad 17: 00$ & $\mathrm{NO}$ & 2.21105 & 29.07385 & $\mathrm{NaN}$ & 2.61468 & 4.82573 & 9.70025 \\
\hline 21 & \begin{tabular}{l|l}
1 & $\mathrm{G} 20$
\end{tabular} & 5/24/08 19:00 & LO & 0.43817 & 49.85552 & 0.05551 & 3.05907 & 3.49724 & 14.83288 \\
\hline 22 & $\mathrm{G} 21$ & 5/24/08 21:00 & $\mathrm{OO}$ & 5.79518 & 25.28606 & 0.07557 & 2.44932 & 8.24450 & 9.45159 \\
\hline 23 & $3 \mathrm{G} 22$ & $5 / 25 / 08$ & NO & 1.86778 & 8.71192 & 0.05421 & 1.55020 & 3.41799 & 22.52041 \\
\hline 24 & $\begin{array}{l}4 \mathrm{G} 23 \\
\end{array}$ & $5 / 25 / 08$ & $\mathrm{NO}$ & 2.12019 & 9.42853 & $\mathrm{NaN}$ & 1.22983 & 3.35002 & 9.90792 \\
\hline 25 & \begin{tabular}{|l|l|}
5 & 024 \\
\end{tabular} & $5 / 25 / 08$ & MM & 2.03942 & 14.02506 & $\frac{1}{0.06469}$ & 2.34597 & 4.38539 & $\mathrm{NaN}$ \\
\hline 26 & 6 & $5 / 25 / 08$ & MM & 0.79759 & 13.20608 & 0.11192 & 2.74903 & 3.54662 & 6.54120 \\
\hline 27 & $7 \mathrm{G} 26$ & $5 / 22 / 08$ & SN & 3.08942 & 7.26846 & $\mathrm{NaN}$ & 3.12108 & 6.21049 & 13.70468 \\
\hline & G26B & $5 / 22 / 08$ & SN & 3.25096 & 6.59280 & 0.10093 & 3.74116 & 6.99211 & $\mathrm{NaN}$ \\
\hline 28 & G27 & $5 / 24 / 08$ & $\mathrm{NO}$ & 1.14086 & 22.72674 & $\mathrm{NaN}$ & 2.82137 & 3.96223 & 13.41685 \\
\hline 29 & \begin{tabular}{|l|l|}
9 & G28 \\
\end{tabular} & $5 / 26 / 08$ & $\mathrm{NO}$ & 2.38269 & 9.11117 & 0.05438 & 1.22983 & 3.61252 & 5.52427 \\
\hline & G28-TOC-DOC (0.3 um) & $5 / 26 / 08$ & & & & & & & \\
\hline 30 & $\begin{array}{l}\mathrm{G} 29 \\
\end{array}$ & 5/27/08 14:48 & $\mathrm{NO}$ & 1.24182 & 33.27113 & $\mathrm{NaN}$ & 1.31251 & 2.55433 & 10.70360 \\
\hline & G29B & $5 / 27 / 08 \quad 14: 55$ & $\mathrm{NO}$ & & & & & & \\
\hline & G29C & $5 / 27 / 0814: 55$ & $\mathrm{NO}$ & & & & & & \\
\hline 31 & $1 \mathrm{G} 30$ & $5 / 27 / 0815: 50$ & NO & 11.00479 & 14.22981 & $\mathrm{NaN}$ & 0.61285 & 11.61763 & 1.64030 \\
\hline 32 & 2 & $5 / 27 / 0816: 00$ & MM & $<0.05$ & 5.93762 & 0.06600 & 0.38962 & 0.38962 & 18.57452 \\
\hline 33 & 3 & 5/25/08 16:00 & $\mathrm{NO}$ & $<0.05$ & 10.85151 & 0.06550 & 0.67382 & 0.67382 & 12.26710 \\
\hline 34 & \begin{tabular}{|l|l}
$4 \mathrm{G} 33$ \\
\end{tabular} & $5 / 26 / 08 \quad 16: 00$ & $\mathrm{NO}$ & 1.03990 & 9.01904 & $\mathrm{NaN}$ & 1.48820 & 2.52810 & 16.75306 \\
\hline 35 & \begin{tabular}{|l|l|}
$5 \mathrm{G} 34$ \\
\end{tabular} & $5 / 27 / 08 \quad 16: 00$ & NO & 1.33269 & 33.06639 & 0.05514 & 1.36418 & 2.69687 & 8.97601 \\
\hline 36 & 6 G35 & $5 / 28 / 08 \quad 16: 30$ & MO & 0.64413 & 39.61824 & 0.05750 & 1.99460 & 2.63873 & 12.20426 \\
\hline 37 & $7 \mathrm{G} 36$ & $5 / 28 / 0810: 30$ & $\mathrm{NO}$ & & & & & & \\
\hline 38 & \begin{tabular}{|l|l|}
8 & G37 \\
\end{tabular} & $5 / 28 / 08$ & $\mathrm{MO}$ & 0.82384 & 31.01894 & 0.05000 & 1.44686 & 2.27070 & 19.54654 \\
\hline 39 & \begin{tabular}{|l|l}
9 & G38
\end{tabular} & $5 / 28 / 08$ & MO & 0.21202 & 3.42949 & 0.08522 & 0.17156 & 0.38357 & 8.75321 \\
\hline 40 & \begin{tabular}{l|l}
039 \\
\end{tabular} & 5/28/08 19:00 & $\mathrm{GW}$ & 0.20798 & 77.90564 & $\mathrm{NaN}$ & 0.57151 & 0.77949 & 4.87017 \\
\hline 41 & $\begin{array}{ll}1 & \mathrm{G} 40\end{array}$ & $5 / 29 / 08 \quad 12: 40$ & $\mathrm{~T}$ & 0.58558 & 3.49091 & $\mathrm{NaN}$ & 0.12298 & 0.70856 & 29.35099 \\
\hline 42 & G41 & $5 / 29 / 0816: 00$ & $\mathrm{NO}$ & 1.35288 & 21.90776 & 0.05432 & 1.31251 & 2.66539 & 13.20681 \\
\hline 43 & \begin{tabular}{|l|l|}
3 & G42
\end{tabular} & $5 / 29 / 08 \quad 13: 41$ & NO & 0.99649 & 7.37084 & 0.06284 & 0.88878 & 1.88527 & 18.66393 \\
\hline 44 & \begin{tabular}{|l|l}
4 & $\mathrm{G} 43$ \\
\end{tabular} & $5 / 29 / 08 \quad 16: 30$ & MM & 0.27966 & 6.58257 & $\mathrm{NaN}$ & 0.72239 & 1.00206 & 6.23266 \\
\hline 45 & 5 G44 & $5 / 29 / 08 \quad 11: 45$ & NO & 1.25192 & 12.59184 & 0.06356 & 1.82924 & 3.08116 & 7.64068 \\
\hline 46 & $\begin{array}{ll}6 & \text { G45 }\end{array}$ & $5 / 30 / 0818: 00$ & NO & 1.09038 & 14.63930 & $\mathrm{NaN}$ & 1.32284 & 2.41322 & 7.04057 \\
\hline 47 & \begin{tabular}{l|l}
7 & $\mathrm{G} 46$
\end{tabular} & $5 / 30 / 0818: 00$ & MI & 0.35740 & 0.88348 & 0.06253 & 0.26870 & 0.62611 & 6.92562 \\
\hline 48 & $\begin{array}{ll}847 \\
\end{array}$ & $5 / 31 / 080: 00$ & NO & 1.23173 & 18.63184 & $\mathrm{NaN}$ & 1.94292 & 3.17465 & $\mathrm{NaN}$ \\
\hline 49 & $9 \mathrm{G} 48$ & $5 / 31 / 086: 45$ & $\mathrm{NO}$ & 1.25192 & 26.61691 & 0.05421 & 2.10828 & 3.36020 & 12.75084 \\
\hline 50 & $\begin{array}{ll}\text { G449 } \\
\end{array}$ & $5 / 31 / 08 \quad 12: 40$ & NO & 0.94096 & 15.04879 & $\mathrm{NaN}$ & 2.10828 & 3.04924 & 9.89169 \\
\hline 51 & \begin{tabular}{l|l}
1 & $\mathrm{G} 50$
\end{tabular} & $5 / 31 / 08 \quad 16: 05$ & MI & 0.49976 & 3.14284 & 0.16018 & 0.28627 & 0.78603 & 8.98478 \\
\hline 52 & \begin{tabular}{|l|l|}
2 & G51
\end{tabular} & $5 / 31 / 08 \quad 18: 25$ & NO & 1.15096 & 4.01301 & 0.05904 & 1.35384 & 2.50480 & 8.21704 \\
\hline 53 & \begin{tabular}{|l|l|}
3 & G52 \\
\end{tabular} & $6 / 1 / 08$ & $\mathrm{NO}$ & 1.24182 & 13.00134 & 0.23000 & 0.90635 & 2.14818 & 16.18194 \\
\hline 54 & \begin{tabular}{l|l}
4 & G53 \\
\end{tabular} & $6 / 1 / 08$ & PL & 0.51490 & 35.42096 & 0.23513 & 2.69735 & 3.21226 & 14.80085 \\
\hline 55 & 5 ICE & $6 / 1 / 08$ & MI & & & & & & \\
\hline 56 & $\begin{array}{l}6 \text { MQ nutrient blank } 1 \text { (May) } \\
\end{array}$ & $6 / 1 / 08$ & $\mathrm{~B}$ & 0.05490 & 1.61376 & $\mathrm{NaN}$ & $\mathrm{NaN}$ & 0.05490 & $\mathrm{NaN}$ \\
\hline 57 & 7) MQ nutrient blank 2 (May) & $6 / 1 / 08$ & B & & & & & & \\
\hline 58 & 8 MQ1 MayDOC & $6 / 1 / 08$ & & & & & & & \\
\hline 59 & \begin{tabular}{|l|l}
9 MQ2 MayDOC \\
\end{tabular} & $6 / 1 / 08$ & & & & & & & \\
\hline 60 & O) MQ1 MayTOC & $6 / 2 / 08$ & & & & & & & \\
\hline 61 & $\begin{array}{ll}1 & \text { MQ2 MayTOC }\end{array}$ & $6 / 2 / 08$ & & & & & & & \\
\hline 62 & G55 & 5/25/08 19:36 & $\mathrm{NO}$ & & & & & & \\
\hline 63 & \begin{tabular}{|l|l|} 
GM50 \\
\end{tabular} & 5/25/08 15:00 & $\mathrm{GW}$ & 0.33923 & 18.73421 & 0.05457 & 21.39281 & 21.73204 & $\mathrm{NaN}$ \\
\hline 64 & \begin{tabular}{l|l}
4 GM51 \\
\end{tabular} & $5 / 25 / 08 \quad 18: 40$ & $\mathrm{GW}$ & 16.15382 & 72.88938 & 0.16428 & 26.87019 & 43.02401 & 55.19301 \\
\hline 65 & \begin{tabular}{|l|l|} 
GM52 \\
\end{tabular} & 5/25/08 19:00 & GW & 6.49181 & 57.84059 & 0.06653 & 62.83491 & 69.32673 & 42.83880 \\
\hline 66 & $\begin{array}{l}6 \text { GM53 } \\
\end{array}$ & $5 / 25 / 08 \quad 19: 20$ & $\mathrm{GW}$ & 1.02981 & 5.95809 & 0.06058 & 77.61352 & 78.64332 & 1.82105 \\
\hline 67 & \begin{tabular}{l|l}
7 & GM54 \\
\end{tabular} & $5 / 25 / 08 \quad 19: 30$ & GW & 1.32259 & 14.84404 & 0.06606 & 75.64993 & 76.97252 & 6.66197 \\
\hline 68 & \begin{tabular}{l|l}
$\mathrm{G} 56$ \\
\end{tabular} & $7 / 10 / 0811: 23$ & NO & 1.16106 & 7.24799 & 0.78035 & 0.48366 & 1.64472 & 6.85804 \\
\hline 69 & $\begin{array}{l}\text { G57 } \\
\end{array}$ & $7 / 10 / 0813: 46$ & NO & 0.18274 & 3.66494 & 0.53597 & 0.28007 & 0.46281 & 18.81834 \\
\hline 70 & 0 G58 & 7/10/08 14:40 & MM & $<0.05$ & 10.06324 & 0.57396 & 1.21949 & 1.21949 & 4.43016 \\
\hline 71 & $\begin{array}{ll}\text { G59 } \\
\end{array}$ & $7 / 11 / 08 \quad 12: 30$ & NO & 0.37356 & 4.97531 & 0.64789 & 0.27904 & 0.65259 & 29.08994 \\
\hline 72 & \begin{tabular}{|l|l|}
2660 \\
\end{tabular} & $7 / 11 / 08 \quad 12: 30$ & $\mathrm{NO}$ & $<0.05$ & 4.07443 & 0.06715 & 0.21083 & 0.21083 & 23.19148 \\
\hline 73 & \begin{tabular}{l|l}
3 & Be/Ra-July
\end{tabular} & $7 / 11 / 0816: 15$ & NO & & & & & & \\
\hline 74 & \begin{tabular}{l|l|}
4 & G61 \\
\end{tabular} & $7 / 11 / 0818: 00$ & $\mathrm{NO}$ & 0.05997 & 5.36433 & 0.07629 & 0.21600 & 0.27597 & 4.42266 \\
\hline 75 & \begin{tabular}{|l|l|}
$5 \mathrm{G} 62$ \\
\end{tabular} & $7 / 12 / 080: 00$ & $\mathrm{NO}$ & $<0.05$ & 4.28942 & 0.07608 & $\mathrm{NaN}$ & 0.00000 & 3.11357 \\
\hline 76 & \begin{tabular}{|l|l|}
663 \\
\end{tabular} & $7 / 12 / 086: 00$ & $\mathrm{NO}$ & 0.12418 & 4.73986 & 0.06610 & 0.37412 & 0.49830 & 7.05343 \\
\hline 77 & \begin{tabular}{l|l|}
7 & $\mathrm{G} 64$ \\
\end{tabular} & $7 / 12 / 08 \quad 12: 50$ & $\mathrm{NO}$ & $<0.05$ & 4.54535 & $\mathrm{NaN}$ & 0.51467 & 0.51467 & 6.08603 \\
\hline 78 & \begin{tabular}{|l|l|}
8655 \\
\end{tabular} & $7 / 12 / 0818: 00$ & $\mathrm{NO}$ & $<0.05$ & 6.62352 & 0.05249 & 0.31934 & 0.31934 & 4.69629 \\
\hline
\end{tabular}




\begin{tabular}{|c|c|c|c|c|c|c|c|c|c|c|}
\hline & Sample ID & Collection Date & Sample Type & $\mu \mathrm{M}$ NH4 & $\mu \mathrm{M}$ Silicate & $\mu \mathrm{M}$ PO4 & $\mu \mathrm{M}$ NO2+NO3 & $\mu$ M DIN & $\mu$ M DON & $\mu M$ TDN \\
\hline 79 & G66 & $7 / 13 / 0813: 50$ & NO & $<0.05$ & 4.62725 & $\mathrm{NaN}$ & 0.46713 & 0.46713 & 5.81655 & 6.28368 \\
\hline 80 & G67 & $7 / 13 / 0818: 45$ & $\mathrm{PL}$ & $<0.05$ & 38.69689 & $\mathrm{NaN}$ & 2.28397 & 2.28397 & 2.73167 & 5.01564 \\
\hline 81 & G68 & $7 / 14 / 0818: 00$ & NO & 0.38163 & 4.14610 & 0.06308 & 0.25113 & 0.63277 & 6.28494 & 6.91770 \\
\hline 82 & G69 & $7 / 15 / 08 \quad 16: 30$ & NO & 0.43817 & 6.19355 & $\mathrm{NaN}$ & 0.23666 & 0.67484 & 6.24287 & 6.91770 \\
\hline 83 & G70 & $7 / 15 / 0815: 24$ & $\mathrm{MO}$ & $<0.05$ & 3.95159 & 0.05277 & 0.05002 & 0.05002 & 17.01205 & 17.06207 \\
\hline 84 & G71 & $7 / 16 / 0822: 00$ & $\mathrm{NO}$ & $<0.05$ & 5.35409 & $\mathrm{NaN}$ & $\mathrm{NaN}$ & 0.00000 & 4.06460 & 4.06460 \\
\hline 85 & G72 & $7 / 19 / 0820: 00$ & $\mathrm{~F}$ & 7.57210 & 3.66494 & 0.05559 & $\mathrm{NaN}$ & 7.57210 & 6.31986 & 13.89196 \\
\hline 86 & G73 & $7 / 22 / 080: 00$ & $\mathrm{~F}$ & 1.42355 & 4.71938 & 0.06588 & $\mathrm{NaN}$ & 1.42355 & 23.56381 & 24.98736 \\
\hline 87 & G74 & $7 / 24 / 0814: 15$ & SWF & $<0.05$ & 4.65796 & 0.05270 & $\mathrm{NaN}$ & 0.00000 & 15.47702 & 15.47702 \\
\hline 88 & G75 & $7 / 24 / 0815: 00$ & F & $<0.05$ & 10.01205 & 0.15402 & 2.22196 & 2.22196 & 23.08241 & 25.30437 \\
\hline 89 & G76 & 7/24/08 15:00 & SWF & & & & & & & \\
\hline 90 & G77 & $7 / 24 / 0815: 00$ & IB & & & & & & & \\
\hline 91 & G78 & $7 / 26 / 0811: 30$ & $\mathrm{~F}$ & 0.08390 & 6.82826 & 0.05175 & $\mathrm{NaN}$ & 0.08390 & 12.54001 & 12.62391 \\
\hline 92 & G79 & $7 / 26 / 0811: 40$ & SWF & $<0.05$ & 7.72914 & 0.10473 & 0.07823 & 0.07823 & 10.64361 & 10.72184 \\
\hline 93 & G80 & $7 / 26 / 0812: 00$ & IB & 0.22211 & 2.53884 & 0.06293 & 0.17569 & 0.39780 & 19.51737 & 19.91518 \\
\hline 94 & A1 & $6 / 1 / 0816: 00$ & NO & 1.58509 & 17.81285 & 0.09272 & 3.26576 & 4.85085 & $\mathrm{NaN}$ & $\mathrm{NaN}$ \\
\hline 95 & A2 & $6 / 3 / 084: 00$ & NO & 2.24134 & 17.19862 & $\mathrm{NaN}$ & 1.48820 & 3.72954 & 17.45369 & 21.18322 \\
\hline 96 & $\mathrm{~A} 3$ & $6 / 4 / 0816: 00$ & NO & 1.84759 & 8.95761 & 0.06643 & 0.88775 & 2.73534 & 22.56903 & 25.30437 \\
\hline 97 & A4 & $6 / 6 / 084: 00$ & NO & 2.03942 & 19.75794 & $\mathrm{NaN}$ & 1.35384 & 3.39326 & 20.64306 & 24.03633 \\
\hline 98 & A5 & $6 / 7 / 0816: 00$ & NO & 2.01923 & 7.68819 & 0.16018 & 0.71619 & 2.73542 & 18.13079 & 20.86621 \\
\hline 99 & A6 & $6 / 9 / 084: 00$ & NO & 1.61538 & 11.46574 & $\mathrm{NaN}$ & 0.99936 & 2.61475 & 19.20250 & 21.81725 \\
\hline 100 & A9 & $6 / 13 / 08 \quad 16: 00$ & NO & 1.74663 & 13.71794 & 0.09446 & 0.75960 & 2.50623 & 16.14090 & 18.64713 \\
\hline 101 & A11 & $6 / 16 / 08 \quad 16: 00$ & NO & 3.33172 & 10.19632 & 0.07328 & 0.49400 & 3.82572 & 18.94256 & 22.76828 \\
\hline 102 & $\mathrm{~A} 12$ & $6 / 18 / 084: 00$ & NO & 0.16558 & 16.89150 & $\mathrm{NaN}$ & 0.66865 & 0.83423 & 24.15313 & 24.98736 \\
\hline 103 & $\mathrm{~A} 13$ & $6 / 19 / 0816: 00$ & NO & 1.54471 & 6.67470 & 0.05382 & 0.67796 & 2.22266 & 11.98630 & 14.20897 \\
\hline 104 & A15 & $6 / 22 / 0816: 00$ & NO & 2.12019 & 26.00267 & 0.06356 & 0.54671 & 2.66689 & 19.15035 & 21.81725 \\
\hline 105 & A17 & $6 / 25 / 0816: 00$ & NO & 1.95865 & 27.53826 & 0.08409 & 0.43922 & 2.39787 & 18.78535 & 21.18322 \\
\hline 106 & $\mathrm{~A} 19$ & $6 / 28 / 0816: 00$ & NO & 1.41346 & 20.78166 & 0.05483 & 0.43406 & 1.84752 & 16.79961 & 18.64713 \\
\hline 107 & $\mathrm{~A} 21$ & $7 / 1 / 0816: 00$ & NO & 1.89807 & 12.79659 & 0.06896 & 0.48160 & 2.37967 & 16.58447 & 18.96414 \\
\hline 108 & $\mathrm{~A} 23$ & $7 / 4 / 0816: 00$ & $\mathrm{NO}$ & 1.18125 & 28.45962 & 0.06345 & 2.40798 & 3.58923 & 14.74089 & 18.33012 \\
\hline
\end{tabular}




\begin{tabular}{|c|c|c|c|c|c|c|c|c|c|c|c|c|c|c|}
\hline \multicolumn{15}{|c|}{ Table A6: Greenland Ice Sheet Margins 2008 Dissolved Organic Carbon (DOC) and Total Nitrogen (TN) } \\
\hline Sample ID & \begin{tabular}{|c|} 
Collection Date \\
\end{tabular} & Sample Type & DOC $(\mu \mathrm{M})$ & 14DOC $(\mu \mathrm{M})$ aliquot & DOC aliquot $(\mu \mathrm{M})$ & $\mathbf{T N}(\mu \mathrm{M})$ & DOC aliquot $(\mu \mathrm{M})$ & $\mathbf{T N}(\mu \mathrm{M})$ & DOC $(\mu \mathrm{M})$ & $\mathrm{TN}(\mu \mathrm{M})$ & DOC run 11.27.10 & TN run 11.27.10 & DOC run 11.28.10 & TN run 11.28.10 \\
\hline & & & \begin{tabular}{|c|}
$\mid$ run 11.25/26.08 \\
\end{tabular} & $\begin{aligned} \operatorname{run} 03.25 .10 \\
\end{aligned}$ & run 11.01.10 & run 11.01.10 & $\begin{aligned} r \text { run 11.27.10 } \\
\end{aligned}$ & run 11.27.10 & $\begin{array}{ll}\text { run 11.28.10 } \\
\end{array}$ & \begin{tabular}{|l|} 
run 11.28.10 \\
\end{tabular} & same day rep & same day rep & same day rep & same day rep \\
\hline Mean MilliQ Blank & & $\begin{array}{ll}\text { Instrument Blank } \\
\end{array}$ & 1.86000 & & & & & & & & & & & \\
\hline Low Carbon Water & & Instrument Std & 1.46900 & & & & & & & & & & & \\
\hline$\frac{\text { Deep Sea Reference Water }}{\text { Mean Millio Blank }}$ & & $\frac{\text { Instrument Std }}{\text { Instrument Blank }}$ & $\frac{47.60300}{1.52400}$ & & & & & & & & & & & \\
\hline Low Carbon Water & & Instrument Std & 0.64200 & & & & & & & & & & & \\
\hline Deep Sea Reference Water & & Instrument Std & 46.52000 & & & & & & & & & & & \\
\hline \begin{tabular}{c|c|c|c|} 
Mean MilliQ Blank & \\
Low Carbon Water &
\end{tabular} & & Instrument Blank & & $\frac{3.79369}{0.99}$ & & & & & & & & & & \\
\hline Deep Sea Reference Water & & $\begin{array}{ll}\text { Instrument Sdd } \\
\text { Instrument Std } \\
\end{array}$ & & 0.99 & & & & & & & & & & \\
\hline Mean MilliQ Blank & & Instrument Blank & & & 1.30000 & 0.00000 & & & & & & & & \\
\hline Low Carbon Water & & Instrument Std & & & 0.11000 & 0.00000 & & & & & & & & \\
\hline Deep Sea Reference Water & & Instrument Std & & & 47.13000 & 38.04000 & & & & & & & & \\
\hline & & Instrument Blank & & & & & & 0.02000 & & & & & & \\
\hline Low Carbon Water & & Instrument Std & & & & & 2.98000 & 0.13000 & & & & & & \\
\hline Deep Sea Reference Water & & Instrument Std & & & & & 48.97000 & 36.09000 & & & & & & \\
\hline $\begin{array}{c}\text { Mean MilliQ Blank } \\
\text { Low Carbon Water }\end{array}$ & & Instrument Blank & 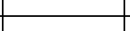 & & & & & & 0.12000 & 0.00462 & & & & \\
\hline Deep Sea Reference Water & & Instrument Std & & & & & & & $\frac{0.8000}{47.54000}$ & \begin{tabular}{|l|l}
0.00000 \\
33.03000 \\
\end{tabular} & & & & \\
\hline & $5 / 17 / 0812: 30 \mathrm{M}$ & MO & & & & & & & & & & & & \\
\hline$\frac{\mathrm{G} 1}{\mathrm{G} 2}$ & \begin{tabular}{|l|l|}
$5 / 17 / 08 ~ 13: 55 \mathrm{M}$ \\
$5 / 170816.04 \mathrm{P}$
\end{tabular} & $\begin{array}{l}\mathrm{MO} \\
\mathrm{MW} \\
\mathrm{p}\end{array}$ & \begin{tabular}{|l|l|}
62.47900 \\
254.5600
\end{tabular} & & 83.51279 & 10.53710 & & & 26648346 _ $>2$ & 8.5553 .3 & & & 264465111 & 8.25417 \\
\hline$\frac{\mathrm{G} 2}{\mathrm{G} 3}$ & $\begin{array}{l}5 / 18 / 0814: 20 / \mathrm{N} \\
\end{array}$ & & 41.87600 & & 41.71098 & 6.55931 & & & 206.48546 & & & & & 8.25411 \\
\hline $\mathrm{G} 4$ & $5 / 18 / 0814: 20 \mathrm{M}$ & & 22.046000 & & & & & & & & & & & \\
\hline G4-TOC-DOC $(0.3 \mathrm{um})$ & $\begin{array}{l}5 / 18 / 0814: 20 \mid \mathrm{M} \\
\end{array}$ & & & & & & & & 21.29080 & 1.38045 & & & & \\
\hline G55 & $5 / 19 / 0812: 41 \mid \mathrm{N}$ & & 49.62800 & 44.18451 & & & & & & & & & & \\
\hline $\begin{array}{l}\text { G5-TOC-DOC (0.3 um) } \\
\text { G6 }\end{array}$ & 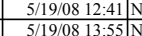 & $\begin{array}{l}\text { NO } \\
\text { No }\end{array}$ & $50.52600 \mathrm{0}$ & & & & & & 73.39478 & 11.16017 & & & & \\
\hline G6-TOC-DOC (0.3 um) & \begin{tabular}{|l|l|l}
$5 / 19 / 08$ & $13: 55 \mathrm{~N}$ \\
\end{tabular} & & & & & & & & 77.30915 & 10.22738 & & & & \\
\hline G7 & 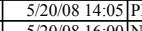 & & $\begin{array}{ll}613.51200 \\
\end{array}$ & & & & & & 652.47734 & 12.74591 & & & & \\
\hline$\frac{\mathrm{G} 8}{\mathrm{G} 9}$ & $\frac{5 / 20 / 08}{50001}$ & & 43.63200 & & 46.97482 & 10.59690 & & & & & & & & \\
\hline G99 & 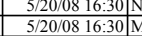 & & 193.48800 & & & & & & 188.31832 & 5.66172 & & & & \\
\hline G11 & $\begin{array}{l}3 / 21 / 0810.30 / 23 / \mathrm{N} \\
5 / 21 / 2\end{array}$ & & 56.09600 & & 56.78820 & 9.81956 & & & 59.65166 & $\mid 9.78968$ & & & & \\
\hline$\overline{\mathrm{G} 12}$ & $5 / 21 / 0814: 10 \mathrm{~N}$ & & 341.71800 & & & & & & & & & & & \\
\hline G12-TOC-DOC (0.3 um) & $5 / 21 / 0814: 10 \mid \mathrm{N}$ & & & & & & & & 347.52322 & 60.05756 & & & & \\
\hline G13 & $\begin{array}{l}5 / 21 / 0816: 25 / \mathrm{N} \\
\end{array}$ & & & & & & & & & & & & & \\
\hline$\frac{\mathrm{G} 14}{\mathrm{G} 15}$ & & & & & & & & & & & & & & \\
\hline$\frac{\mathrm{G} 15}{\mathrm{G} 15 \mathrm{~B}}$ & $\begin{array}{l}5 / 22 / 0817: 00 \mid \mathrm{M} \\
5 / 200817000\end{array}$ & & 15.02800 & 1.15 & 14.24638 & 2.42577 & & & 16.20211 & 1.50530 & & & & \\
\hline$\frac{G 10}{G 16}$ & \begin{tabular}{|l}
$5 / 22208 / 1: 0000 \mathrm{~N}$ \\
$5 / 22 / 08: 00 / \mathrm{N}$
\end{tabular} & & 61.42400 & & 73.98898 & 8.23927 & & & & & & & & \\
\hline$\frac{617}{617}$ & $5 / 22 / 0818: 10 \mathrm{~N}$ & & & & & & & & & & & & & \\
\hline G18 & \begin{tabular}{|l|l|l|l|l|}
$5 / 23 / 08$ & $13: 45$ & $\mathrm{~N}$ \\
\end{tabular} & NO & & & & & & & & & & & & \\
\hline$\frac{\mathrm{G} 19}{\mathrm{G} 20}$ & $\frac{5 / 23 / 0017: 000 \mathrm{~N}}{55 / 24 / 081900 \mathrm{~L}}$ & & - & 146.94962 & & & & & & & & & & 6.29 \\
\hline G21 & $5 / 24 / 0821: 00$ & & & 140.50760 & & & & & & & & & & $\frac{0.29}{8.80}$ \\
\hline$\frac{622}{222}$ & $5 / 25 / 08 \mathrm{~N}$ & & & & & & & & & & & & & 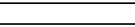 \\
\hline G23 & $5 / 2 / 2+2$ & & 41.391000 & & 41.01600 & 5.22674 & & & 44.91159| & 4.93199| & & & & \\
\hline G24 & $\begin{aligned} 5 / 25 / 280 \mid \mathrm{M} \\
\end{aligned}$ & & & & & & & & & & & & & \\
\hline$\frac{\mathrm{U} 23}{\mathrm{G} 26}$ & 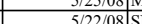 & & & & & & & & & & & & & \\
\hline 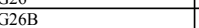 & $\frac{152208 \mathrm{~S}}{5 / 208}$ & & & & & & & & & & & & & \\
\hline G27 & & & & & & & & & & & & & & \\
\hline$\frac{628}{268}$ & $5 / 26008 \mathrm{~N}$ & & 31.93500 & & & & & & & & & & & \\
\hline G28-TOC-DOC $(0.3 \mathrm{um})$ & $5 / 26 / 08$ & & & & & & & & 68.50181 & 10.64594 & & & & \\
\hline G29 & $\begin{array}{l}5 / 27 / 0814: 48 \mathrm{~N} \\
\end{array}$ & NO & 39.16900 & & $\begin{array}{ll}38.96967 \\
\end{array}$ & 5.72788 & & & & & & & & \\
\hline G29B & 5/27/08 14:55/N & NO & & & & & & & & & & & & \\
\hline 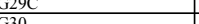 & $5 / 2 / 270$ & & 40 & & & ( & & & & & & & & \\
\hline$\frac{600}{631}$ & 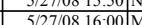 & & 42.81800 & & (29,02115 & 6.28596 & & & & & & & & \\
\hline$\frac{11}{632}$ & 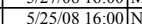 & & $x^{2}$ & & & & & & & & & & & \\
\hline G33 & & & & & & & & & & & & & & \\
\hline G34 & & & & & & & & & & & & & & \\
\hline 635 & $5 / 2808$ & Mo & $96.50200 \mathrm{0}$ & & & & & & 97.43147 & 5.20226 & & & & \\
\hline G36 & $5 / 280810: 30 \sqrt{\mathrm{N}}$ & No & & & & & & & & & & & & \\
\hline G37 & $88 \mid \mathrm{M}$ & & & & & & & & & & & & & \\
\hline G38 & $\begin{array}{r}5 / 28 / 08 \mid \mathrm{M} \\
5 / 2808 \cdot 0 \cdot 0.6\end{array}$ & MO & 33.27200 & & 35.26311 & 5.75350 & & & & & & & & \\
\hline G49 & \begin{tabular}{|l}
$5 / 29 / 088112: 400 \mathrm{~T}$ \\
\end{tabular} & & 406.43800 & 375.44621 & & & & & 467.76786 & 28.82819 & & & & \\
\hline G41 & $5 / 29 / 08$ 16:00/N & & & & & & & & & & & & & \\
\hline$\frac{642}{612}$ & $5 / 29$ & & & & 30.192 & 40 & & & & & & & & \\
\hline G43 & $5 / 29 / 0816: 30 \mid \mathrm{M}$ & & 46.99400| & & 13.15 & 9.99 & & & & & & & & \\
\hline
\end{tabular}




\begin{tabular}{|c|c|c|c|c|c|c|c|c|c|c|c|c|c|c|}
\hline Sample ID & \begin{tabular}{|l|} 
Collection Date \\
\end{tabular} & Sample Type & $\operatorname{DOC}(\mu \mathrm{M})$ & 14DOC $(\mu \mathrm{M})$ aliquot & DOC aliquot $(\mu \mathrm{M})$ & \begin{tabular}{|l|l|}
$T N(\mu M)$ \\
\end{tabular} & DOC aliquot $(\mu \mathrm{M})$ & $\mathrm{TN}(\mu \mathrm{M})$ & DOC $(\mu \mathrm{M})$ & $\mathrm{TN}(\mu \mathrm{M})$ & DOC run 11.27.10 & TN run 11.27.10 & DOC run 11.28.10 & TN run 11.28.10 \\
\hline & & & run 11.25/26.08 & $\begin{array}{l}\text { run 03.25.10 } \\
\end{array}$ & run 11.01.10 & run 11.01.10 & \begin{tabular}{|l|l|} 
run 11.27.10 & \\
\end{tabular} & run 11.27.10 & run 11.28.10 & run 11.28.10 & same day rep & same day rep & \begin{tabular}{|l|} 
same day rep \\
\end{tabular} & same day rep \\
\hline G445 & $\frac{5 / 29 / 0811: 45[\mathrm{~N}}{5 / 30 / 0818.00 \mathrm{~N}}$ & & 2830600 & & 3188473 & 817093 & & & & & & & & \\
\hline$\frac{346}{646}$ & $\frac{5 / 30 / 0818: 000 \mathrm{~N}}{5 / 30 / 0818: 00 / \mathrm{M}}$ & & 28.396000 & & 31.88473 & 8.17093 & & & & & & & & \\
\hline 647 & $5 / 31 / 080: 00 \mathrm{~N}$ & & 27.62300 & & 24.53595 & 6.07241 & & & & & & & & \\
\hline$\frac{648}{490}$ & \begin{tabular}{|l|l|l|l|l|}
$5 / 31 / 08: 45$ & \\
\end{tabular} & & 31.26784 & & & & 39.56971 & 5.47377 & 39.20517 & 5.44862 & 38.18809 & 6.39218 & & \\
\hline 649 & 5/31/08 12:400 & & 28.39883 & & & & 33.28243] & 6.31961 | & & & & & & \\
\hline G50 & $\begin{array}{l}5 / 31 / 08 \quad 16: 05 \mathrm{M} \\
\end{array}$ & & 16.13685 & & & & 23.08766 & & & & & & & \\
\hline$\frac{651}{652}$ & \begin{tabular}{|l|l|l|l|}
$5 / 31 / 08$ & $18: 25$ & $\mathrm{~N}$ \\
\end{tabular} & & 23.06976 & & & & 28.85151 & 5.36115 & & & & & & \\
\hline$\frac{\mathrm{G} 52}{553}$ & 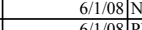 & & & & & & & & & & & & & \\
\hline$\frac{\mathrm{G} 33}{\mathrm{CE}}$ & $\frac{61 / 1 / 188 \mathrm{P}}{66108 \mathrm{M}}$ & & & 60.78510 & & & & & & & & & & \\
\hline MQ nutrient blank 1 (May) & & & 5.08892 & & & & & & & & & & & \\
\hline MQ nutrient blank 2 (May) & \begin{tabular}{|c|c|}
$6 / 1 / 08 \mathrm{~B}$ \\
\end{tabular} & & 7.97710 & & & & & & & & & & & \\
\hline MQ1 MayDOC & $\begin{array}{r}6 / 1 / 08 \\
\end{array}$ & & 5.08892 & & & & 11.57823 & 1.62141 & 10.19600 & 1.33716 & & & & \\
\hline MQ2 MayDOC & \begin{tabular}{|c|}
$6 / 1008$ \\
\end{tabular} & & 7.97710 & & & & 7.09862 & 2.17497 & 7.10120 & 1.97457 & & & & \\
\hline MQ1 MayTOC & & & & & & & & & & -0.00462 & & & 12.40395 & 0.11489 \\
\hline MQ2_MayTOC & & & $\begin{array}{l}5.28062 \\
\end{array}$ & & & & & & 7.38254 & 0.39050 & & & & \\
\hline & \begin{tabular}{|l|l|l|l|l|l|}
$5 / 25 / 08: 36$ \\
\end{tabular} & & & & & & & & & & & & & \\
\hline $\begin{array}{l}\text { GM50 } \\
\text { GM51 }\end{array}$ & $\begin{array}{l}5 / 25 / 0815: 00 \mathrm{G} \\
5 / 5 / 0.18 \cdot 40 \mathrm{~A}\end{array}$ & & & & & & & & & & & & & \\
\hline GM552 & $\begin{array}{l}5 / 25 / 70818: 40 \cdot \mathrm{G} \\
5 / 25 / 081900 \mathrm{G}\end{array}$ & & & & & & & & & & & & & \\
\hline GM53 & 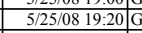 & & & & & & & & & & & & & \\
\hline GM54 & 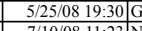 & & & & & & & & & & & & & \\
\hline G56 & \begin{tabular}{|l|}
$7 / 10 / 0811: 23$ \\
$710 / 0813$ \\
\end{tabular} & & 35.35091 & & & & $\begin{array}{l}30.05662 \\
3132824\end{array}$ & $5.38868 \mid$ & & & & & & \\
\hline$\frac{657}{558}$ & 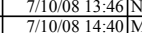 & & 22.57774 & & & & 31.43824 & 3.38167 & & & & & & \\
\hline G58 & \begin{tabular}{|l}
$7 / 1008844440 \mathrm{~N}$ \\
$7 / 1110812: 30 \mid \mathrm{N}$ \\
\end{tabular} & & 31.20394 & & & & 33.31895 & 3.03383 & & & & & & \\
\hline & $\begin{array}{l}7 / 11 / 0812: 30 / \mathrm{N} \\
\end{array}$ & & 31.43397 & & & & 32.06514 & 3.85715 & & & & & & \\
\hline $\begin{array}{l}\text { Be/Ra-July } \\
\text { G61. }\end{array}$ & \begin{tabular}{|c|}
$7 / 11 / 0816: 15 \mid \mathrm{N}$ \\
\end{tabular} & & & & & & & & & & & & & \\
\hline G61 & 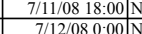 & & $\frac{17.34452}{1529979}$ & 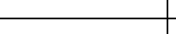 & & & 27.81682 & $\frac{2.56836}{3.73703}$ & 28.42841 & 3.03293 & 27.34207 & 2.69349 & & \\
\hline$\frac{602}{663}$ & \begin{tabular}{|l}
$/ 1 / 12700: 0000 \mid \mathrm{N}$ \\
$7 / 1 / 00 \mathrm{~N}$
\end{tabular} & & 13.29919 & 14.10522 & & & 27.8851 & 3.1.71003 & & & & & & \\
\hline$\frac{664}{669}$ & $7 / 12 / 0812: 50 \mid \mathrm{N}$ & & 13.14004 & & & & 22.60075 & 3.08137 & & & & & & \\
\hline 665 & 7 7/12/08 18:00]吕 & & 11.574455 & - & & & 19.02193 & 1.26205 & & & & & & \\
\hline G66 & 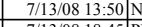 & $O$ & 10.98030 & 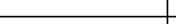 & & & $19.86794]$ & 0.25755 & 18.06144 & 0.70980 & 17.69509 & 1.27181 & & \\
\hline G67 & $7 / 13 / 208$ 18:45 $[\mathrm{P} /$ & & $30.35410 \mid$ & & & & 37.98724 & 4.55034 & & & & & & \\
\hline$\frac{668}{669}$ & 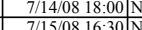 & & $\frac{12.81416}{1320394}-150$ & 22.13297| & & & 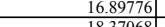 & $1.48127 \mid$ & 16.97887 & 1.53065 & 16.27695 & 1.23628 & & \\
\hline G70 & $\frac{1 / 15 / 0816: 30 / \mathrm{N}}{7 / 15 / 0815.24 \mathrm{M}}$ & & $\frac{13.243944}{124495}$ & & & & $\frac{18.37308}{21767}$ & 2.3 .38914 & & & & & & \\
\hline G71 & $7 / 16 / 08222: 00 \mid \mathrm{N}$ & & $\frac{12.49994}{51.29340}$ & & & & $\frac{21.5067}{580663}$ & $\frac{1.17308}{24832}$ & & & & & & \\
\hline$\frac{672}{672}$ & $7 / 19 / 0820: 00 \mid \mathrm{F}$ & & 60.08573 & 46.30542 & & & 59.84360 & 3.78708 & & & & & & \\
\hline G73 & 7/22/08 0:00 F & & 85.44036 & & & & & & 101.16236 & 4.78370 & & & & \\
\hline G74 & $7 / 24 / 08$ 14:15: & & & & & & & & & & & & & \\
\hline G75 & 7/24/08 15:00 $\mathrm{F}$ & & & & & & & & & & & & & \\
\hline G76 & $7 / 24 / 08$ 15:00 S & & & & & & & & & & & & & \\
\hline Gi7 & 7/24/08 15:00|II & & & & & & & & & & & & & \\
\hline G78 & $7.2608011: 30 \mid \mathrm{F}$ & & & & & & & & & & & & & \\
\hline G89 & $\begin{array}{l}7 / 26 / 0811: 40 \mathrm{~S} \\
7 / 26 / 0812.00 \mathrm{II}\end{array}$ & & & & & & & & & & & & & \\
\hline 000 & 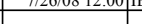 & & & & & & & & & & & & & \\
\hline & & & & & & & & & & & & & & \\
\hline & & & & & & & & & & & & & & \\
\hline & & & & & & & & & & & & & & \\
\hline & & & & & & & & & & & & & & \\
\hline & & & & & & & & & & & & & & \\
\hline & & & & & & & & & & & & & & \\
\hline & & & & & & & & & & & & & & \\
\hline & & & & & & & & & & & & & & \\
\hline & & & & & & & & & & & & & & \\
\hline & & & & & & & & & & & & & & \\
\hline & & & & & & & & & & & & & & \\
\hline & & & & & & & & & & & & & & \\
\hline
\end{tabular}




\begin{tabular}{|c|c|c|c|c|c|c|c|c|c|c|c|c|}
\hline \multicolumn{13}{|c|}{ Table A7: Greenland Ice Sheet Margins 2008 Particulate Organic Carbon (POC) and Nitrogen (PON) } \\
\hline Sample ID & GFF \# & Dry Filter Mass (mg) & Vol Fil (mL) & Date Collected & Sample Type & mmol N & mmol C & Total Filter + Spl (mg) & Sub-sample run (mg) & mg of sample run & $\% \mathrm{OC}$ & $\% \mathbf{N}$ \\
\hline G1\#35 & 35 & 127.1 & 120 & 5/17/08 13:55 & MO & 0.277542 & 4.296135 & 273.79 & 42.74 & 22.89904891 & 0.225321962 & 0.016980459 \\
\hline G2\#25 & 25 & 115.7 & 200 & 5/17/08 16:04 & $\mathrm{PW}$ & $\mathrm{NaN}$ & 3.082921 & 126.5 & 23.13 & 1.974735178 & 1.87497976 & $\mathrm{NaN}$ \\
\hline G3\#2 & 2 & 127.9 & 200 & $5 / 18 / 08 \quad 14: 20$ & NO & 0.123126 & 8.175528 & 278.66 & 48.8 & 26.40166511 & 0.371901122 & 0.006533653 \\
\hline G4\#50 & 50 & 127.2 & 200 & $5 / 18 / 08 \quad 14: 20$ & MI & 0 & 3.768187 & 153.49 & 19.83 & 3.396512476 & 1.332423228 & 0 \\
\hline G5\#77 & 77 & 130.6 & 120 & $5 / 19 / 08 \quad 12: 41$ & $\mathrm{NO}$ & 0.270584 & \begin{tabular}{|l}
7.414562 \\
\end{tabular} & 173.62 & 24.83 & 6.152439811 & 1.447375295 & 0.061615936 \\
\hline G6\#87 & 87 & 132.5 & 150 & 5/19/08 13:55 & NO & $\mathrm{NaN}$ & 6.496627 & 171.55 & 23.86 & 5.431262023 & 1.436581169 & $\mathrm{NaN}$ \\
\hline G7\#54 & 54 & 130.5 & 220 & 5/20/08 14:05 & PL & 0.045862 & 3.134611 & 133.71 & 24.02 & 0.576652457 & 6.528486469 & 0.111424122 \\
\hline G8\#49 & 49 & 127.4 & 125 & 5/20/08 16:00 & NO & $\mathrm{NaN}$ & 7.154256 & 159.48 & 32.27 & 6.491231502 & 1.323672001 & $\mathrm{NaN}$ \\
\hline G10\#1 & 1 & 127.7 & 150 & $5 / 20 / 08 \quad 16: 30$ & MF & 0.101247 & 3.856474 & 150.37 & 18.95 & 2.856929574 & 1.621189933 & 0.049650042 \\
\hline G11\#40 & 40 & 124.9 & 150 & $5 / 21 / 08 \quad 14: 23$ & NO & $\mathrm{NaN}$ & 5.162527 & 155.09 & 21.15 & 4.117083629 & 1.505967698 & NaN \\
\hline G12\#90 & 90 & 133.2 & 150 & $5 / 21 / 08 \quad 14: 10$ & NO & 1.022957 & 24.12706 & 153.24 & 22.37 & 2.925442443 & 9.905031333 & 0.489896128 \\
\hline G15\#85 & 85 & 132.4 & 250 & 5/22/08 17:00 & MI & 0 & 2.788566 & 130.15 & 58.85 & $\mathrm{NaN}$ & $\mathrm{NaN}$ & $\mathrm{NaN}$ \\
\hline G16\#84 & 84 & 131.6 & 175 & 5/22/08 18:00 & NO & 0.024484 & 6.972121 & 157.07 & 32.18 & 5.218212262 & 1.604671638 & 0.006573537 \\
\hline $\mathrm{G} 20 \# 98$ & 98 & 133.2 & 1025 & 5/24/08 19:00 & LO & 1.36338 & 6.204377 & 191.25 & 28.95 & 8.787176471 & 0.847992112 & 0.217372982 \\
\hline G21\#23 & 23 & 124.4 & 300 & 5/24/08 21:00 & $\mathrm{OO}$ & 0 & 7.384476 & 116.4 & 45.46 & $\mathrm{NaN}$ & $\mathrm{NaN}$ & $\mathrm{NaN}$ \\
\hline $\mathrm{G} 23 \# 20$ & 20 & 72.4 & 450 & $5 / 25 / 08$ & NO & 1.102413 & 8.669142 & 444.59 & 72.14 & 60.39224139 & 0.172400285 & 0.02557416 \\
\hline G28\#21 & 21 & 128.2 & 150 & $5 / 26 / 08$ & $\mathrm{NO}$ & 0 & 4.08573 & 301.28 & 35.33 & 20.29645645 & 0.241764442 & 7 \\
\hline G29\#39 & 39 & 128.1 & 150 & $5 / 27 / 08 \quad 14: 48$ & NO & 0.325543 & 4.559665 & 298.13 & 45.13 & 25.73861705 & 0.212760349 & 0.017719897 \\
\hline G30\#46 & 46 & 125.7 & 100 & 5/27/08 15:50 & NO & 0 & 4.4584 & 165.6 & 25.82 & 6.221123188 & 0.860702883 & 0 \\
\hline G35\#28 & 28 & 126.5 & 150 & $5 / 28 / 08 \quad 16: 30$ & MO & 0.025649 & 7.296061 & 158.12 & 23.94 & 4.787394384 & 1.830342121 & 0.007505964 \\
\hline G38\#82 & 82 & 132.9 & 150 & $5 / 28 / 08$ & MO & 0.141854 & 4.533516 & 199.84 & 30.95 & 10.36725881 & 0.525187285 & 0.019169678 \\
\hline G40\#10 & 10 & 105.8 & 850 & $5 / 29 / 08 \quad 12: 40$ & $\mathrm{~T}$ & 0.065672 & \begin{tabular}{|l|}
11.271672 \\
\end{tabular} & 130.04 & 28.66 & 5.342343894 & 2.533958677 & 0.017222231 \\
\hline $\mathrm{G} 40 \# 42$ & 42 & 124 & 400 & $5 / 29 / 08 \quad 12: 40$ & $\mathrm{~T}$ & $\mathrm{NaN}$ & 1.408601 & 129.06 & 19.38 & 0.759823338 & 2.226477289 & $\mathrm{NaN}$ \\
\hline G40\#51 & 51 & 134.2 & 150 & $5 / 29 / 08 \quad 12: 40$ & $\mathrm{~T}$ & $\mathrm{NaN}$ & 2.171532 & 132.18 & 21.13 & $\mathrm{NaN}$ & $\mathrm{NaN}$ & $\mathrm{NaN}$ \\
\hline G42\#80 & 80 & 130.9 & 150 & 5/29/08 13:41 & NO & 0.041543 & 7.204174 & 180.05 & 18.62 & 5.082882533 & 1.702225724 & 0.011450492 \\
\hline G43\#88 & 88 & 131.3 & 150 & $5 / 29 / 08 \quad 16: 30$ & MM & 0.343741 & \begin{tabular}{|l|}
11.982439 \\
\end{tabular} & \begin{tabular}{l|l|}
208.3 \\
\end{tabular} & 35.13 & 12.98612578 & 1.108175728 & 0.037084287 \\
\hline G45\#27 & 27 & 128 & 150 & 5/30/08 18:00 & NO & $\mathrm{NaN}$ & 6.784466 & 191.18 & 24.44 & 8.07678209 & 1.008835406 & $\mathrm{NaN}$ \\
\hline $\mathrm{G} 47 \# 24$ & 24 & 126 & 150 & $5 / 31 / 080: 00$ & NO & 0.356797 & 7.808198 & 182.01 & 31.2 & 9.601186748 & 0.976717337 & 0.052063638 \\
\hline G48\#4 & 4 & 128.7 & 150 & $5 / 31 / 086: 45$ & NO & 0.051144 & 7.752725 & 194.42 & 29.49 & 9.968536159 & 0.934041101 & 0.00718792 \\
\hline G49\#22 & 22 & 107.5 & 150 & $5 / 31 / 08 \quad 12: 40$ & NO & $\mathrm{NaN}$ & 6.664277 & 170.02 & 29.04 & 10.67863075 & 0.749515296 & $\mathrm{NaN}$ \\
\hline G50\#13 & 13 & 114.2 & 150 & 5/31/08 16:05 & MI & $\mathrm{NaN}$ & 1.230902 & 126.54 & 22 & 2.145408566 & 0.689059116 & $\mathrm{NaN}$ \\
\hline G51\#43 & 43 & 125.7 & 150 & $5 / 31 / 08 \quad 18: 25$ & NO & 0.275453 & \begin{tabular}{|l|l|}
11.391775 \\
\end{tabular} & 174.15 & 29.12 & 8.101429802 & 1.68877871 & 0.047634718 \\
\hline G53\#16 & 16 & 106.3 & 250 & $6 / 1 / 08$ & $\mathrm{PL}$ & $\mathrm{NaN}$ & 4.597002 & 201.71 & 29.35 & 13.88272024 & 0.397688626 & $\mathrm{NaN}$ \\
\hline G53\#30 & 30 & 127.7 & 250 & $6 / 1 / 08$ & $\mathrm{PL}$ & 0.362953 & 5.260505 & \begin{tabular}{|l|}
201.28 \\
\end{tabular} & 26.65 & 9.742185016 & 0.648506093 & 0.052195342 \\
\hline G56\#75 & 75 & 131.3 & 150 & $7 / 10 / 0811: 23$ & NO & 0.288378 & 5.479742 & 162.647 & 21.804 & 4.202290777 & 1.566090953 & 0.096142315 \\
\hline G57\#61 & 61 & 129.1 & 150 & $7 / 10 / 08 \quad 13: 46$ & $\mathrm{NO}$ & 0.281382 & 5.471271 & \begin{tabular}{|l|l|}
157.098 \\
\end{tabular} & 20.904 & 3.72551014 & 1.763784377 & 0.105815405 \\
\hline $\mathrm{G} 60 \# 73$ & 73 & 131 & 160 & $7 / 11 / 08 \quad 12: 30$ & NO & 0.378035 & 7.982309 & 198.546 & 20.132 & 6.848972389 & 1.39973594 & 0.077329337 \\
\hline $\mathrm{G} 61 \# 72$ & 72 & 130.1 & 180 & 7/11/08 18:00 & NO & 0.377347 & 7.707486 & 171.506 & 26.348 & 6.361091087 & 1.455204918 & 0.083108905 \\
\hline G63 \#32 & 32 & 124 & 250 & 7/12/08 6:00 & NO & 0.547705 & 4.82467 & 142.935 & 22.273 & 2.950566726 & 1.963835917 & 0.260063431 \\
\hline G63 \#33 & 33 & 127.8 & 250 & $7 / 12 / 086: 00$ & NO & 0.604943 & \begin{tabular}{|l|}
11.272938 \\
\end{tabular} & 348.731 & 45.934 & 29.10049452 & 0.465242892 & 0.029124101 \\
\hline G63\#29 & 29 & 127.6 & 250 & $7 / 12 / 086: 00$ & NO & 0.352117 & \begin{tabular}{|l|}
11.522167 \\
\end{tabular} & 228.73 & 33.034 & 14.60555423 & 0.947456194 & 0.033775902 \\
\hline G63\#31 & 31 & 128.4 & 250 & $7 / 12 / 086: 00$ & NO & 0.227422 & 4.292362 & \begin{tabular}{|l|l|}
149.089 \\
\end{tabular} & 19.661 & 2.72834635 & 1.889469439 & 0.116780926 \\
\hline G63\#36 & 36 & 128.7 & 250 & $7 / 12 / 086: 00$ & NO & 0.190678 & 3.791131 & 148.229 & 18.064 & 2.379911191 & 1.91315883 & 0.112248104 \\
\hline
\end{tabular}




\begin{tabular}{|c|c|c|c|c|c|c|c|c|c|c|c|c|}
\hline Sample ID & GFF \# & Dry Filter Mass (mg) & Vol Fil (mL) & Date Collected & Sample Type & mmol N & mmol C & Total Filter + Spl (mg) & Sub-sample run (mg) & mg of sample run & $\% \mathrm{OC}$ & $\% \mathbf{N}$ \\
\hline G63\#37 & 37 & 128.3 & 250 & 7/12/08 6:00 & NO & 0.443648 & 8.061312 & 174.189 & 33.759 & 8.893596903 & 1.088607432 & 0.069887394 \\
\hline G63\#38 & 38 & 126.7 & 250 & 7/12/08 6:00 & NO & 0.16677 & 3.499376 & 147.445 & 16.913 & 2.379600427 & 1.766158014 & 0.098186317 \\
\hline G63\#41 & 41 & 128.2 & 250 & 7/12/08 6:00 & NO & 0.268091 & 4.697603 & 158.682 & 20.14 & 3.868790915 & 1.458290536 & 0.097083282 \\
\hline G63\#53 & 53 & 127.5 & 250 & 7/12/08 6:00 & NO & 0.247867 & 4.436359 & 154.772 & 20 & 3.524151655 & 1.511872155 & 0.098537783 \\
\hline G63\#58 & 58 & 131.4 & 250 & 7/12/08 6:00 & NO & 0.260259 & 4.863794 & 149.752 & 21.591 & 2.645961536 & 2.207672726 & 0.137803658 \\
\hline G63\#8 & 8 & 122.8 & 250 & 7/12/08 6:00 & $\mathrm{NO}$ & 0.40107 & 7.064618 & 186.877 & 30.758 & 10.54640414 & 0.804502236 & 0.053278785 \\
\hline G63\#9 & 9 & 102.1 & 500 & 7/12/08 6:00 & NO & 0.659649 & 10.83842 & 194.52 & 31.93 & 15.1705254 & 0.858041601 & 0.060918702 \\
\hline G63\#93 & 93 & 131.6 & 250 & 7/12/08 6:00 & $\mathrm{NO}$ & 0.280912 & 5.58679 & 151.324 & 21.26 & 2.77108879 & 2.421335271 & 0.142022684 \\
\hline G63\#94 & 94 & 130.6 & 250 & 7/12/08 6:00 & $\mathrm{NO}$ & 0.557181 & 10.803018 & 323.73 & 42.291 & 25.2298546 & 0.514248879 & 0.030939983 \\
\hline G63\#95 & 95 & 130.9 & 250 & 7/12/08 6:00 & NO & 0.431809 & 7.603239 & 172.705 & 31.796 & 7.69654486 & 1.186440183 & 0.078602025 \\
\hline G64\#70 & 70 & 128.7 & 170 & $7 / 12 / 08 \quad 12: 50$ & $\mathrm{NO}$ & 0.274106 & 5.637766 & 219.152 & 30.317 & 12.5129284 & 0.541116923 & 0.030690023 \\
\hline G65\#69 & 69 & 129.7 & 175 & 7/12/08 18:00 & $\mathrm{NO}$ & 0.316257 & 5.866677 & 294.569 & 34.095 & 19.08282458 & 0.369226194 & 0.023218563 \\
\hline G66\#6 & 6 & 105.9 & 175 & $7 / 13 / 08 \quad 13: 50$ & $\mathrm{NO}$ & 0.209195 & 4.000165 & 158.111 & 17.829 & 5.887445649 & 0.816007128 & 0.049780952 \\
\hline G68\#14 & 14 & 123.9 & 175 & 7/14/08 18:00 & NO & 0.527302 & 4.417633 & 162.606 & 18.218 & 4.336530682 & 1.223461206 & 0.170354982 \\
\hline G69\#1 & 1-Jul & 129.7 & 180 & $7 / 15 / 08 \quad 16: 30$ & $\mathrm{NO}$ & 0.325954 & 6.733187 & 389.806 & 35.102 & 23.42252508 & 0.34524707 & 0.019496664 \\
\hline $\mathrm{G} 70 \# 2$ & 2-Jul & 130.6 & 200 & 7/15/08 15:24 & $\mathrm{MO}$ & 0.557213 & 4.951474 & 223.819 & 30.036 & 12.50977747 & 0.475365837 & 0.062403601 \\
\hline G71 \#12 & 12-Jul & 130.8 & 600 & 7/16/08 22:00 & NO & 0.935084 & \begin{tabular}{|l}
14.768116 \\
\end{tabular} & 224.296 & 36.376 & 15.16304569 & 1.169719311 & 0.086397745 \\
\hline G71\#10 & 10-Jul & 130.2 & 200 & 7/16/08 22:00 & NO & 1.106692 & \begin{tabular}{|l|}
16.515882 \\
\end{tabular} & 238.229 & 32.036 & 14.52727016 & 1.365402692 & 0.106728657 \\
\hline G71\#11 & 11-Jul & 132.1 & 600 & 7/16/08 22:00 & NO & 0.851009 & 13.619846 & 465.699 & 42.165 & 30.20449225 & 0.541556366 & 0.039473067 \\
\hline G71\#13 & 13-Jul & 130.5 & 500 & $7 / 16 / 0822: 00$ & $\mathrm{NO}$ & 0.514759 & 7.886768 & 207.341 & 20.788 & 7.704075451 & 1.229480259 & 0.093609793 \\
\hline G71\#17 & 17-Jul & 133 & 550 & $7 / 16 / 0822: 00$ & $\mathrm{NO}$ & 0.944958 & \begin{tabular}{|l|l|}
18.119363 \\
\end{tabular} & 1650.47 & 108.862 & 100.0895618 & 0.21741883 & 0.013227016 \\
\hline G71\#18 & 18-Jul & 132.9 & 600 & $7 / 16 / 08$ 22:00 & $\mathrm{NO}$ & 0.701155 & \begin{tabular}{|l|l|}
11.208638 \\
\end{tabular} & 269.046 & 35.681 & 18.05574298 & 0.745556354 & 0.054404719 \\
\hline G71\#19 & 19-Jul & 132.8 & 500 & 7/16/08 22:00 & $\mathrm{NO}$ & 1.417413 & 22.457277 & 2378.427 & 272.616 & 257.3944251 & 0.104785448 & 0.00771499 \\
\hline G72\#15 & 15-Jul & 130.2 & 2200 & 7/19/08 20:00 & $\mathrm{F}$ & 2.791187 & 4.232608 & 155.6 & 29.79 & 4.862892031 & 1.04533736 & 0.804141475 \\
\hline G73\#16 & 16-Jul | & 133.4 & 4700 & 7/22/08 0:00 & $\mathrm{F}$ & 0.788436 & 5.016597 & 172.505 & 28.701 & 6.506203327 & 0.92602894 & 0.169776148 \\
\hline
\end{tabular}




\begin{tabular}{|c|c|c|c|c|c|c|c|c|c|}
\hline \multicolumn{10}{|c|}{ Table A8. Dissolved and Particulate Radiocarbon for Inland Lake and Margin Samples } \\
\hline \multicolumn{10}{|c|}{2008 MARGIN \& 2010 LAKE DOC SAMPLES } \\
\hline Receipt \# & Sample & Type & F Modern & Fm Err & Age & Age Err & $813 \mathrm{C}$ & $\Delta \mathbf{1 4 C}$ & {$[\mathrm{DOC}](\mu \mathrm{m} / \mathrm{kg})$ on line } \\
\hline 82413 & SL DOC (South Lake - Das July 62010 21:00 GRT) & DOC & 0.7484 & 0.004 & 2330 & 45 & -23.66 & -257 & 43 \\
\hline 82414 & NNL DOC (North Lake - Das July 32010 14:15 GRT) & DOC & 0.795 & 0.0041 & 1840 & 40 & -21.08 & -210.74 & 22.1 \\
\hline 78141 & Greenland15 (G15) (N Supraglacial May 22) & DOC & 0.6647 & 0.0015 & 3280 & 20 & -24.66 & -340.1 & 9.85 \\
\hline 79623 & MC 2FjordWater (Fjord seawater July 19) & $\mathrm{DOC}$ & 0.5863 & 0.0027 & 4290 & 35 & -21.61 & -417.8 & 42.4 \\
\hline 79622 & Greenland53 TOCfiltered (Clark Lake June 1) & $\mathrm{DOC}$ & 0.698 & 0.0026 & 2890 & 30 & -26.91 & -306.8 & $\overline{75.2}$ \\
\hline 78142 & Greenland20 (G20-TOC) (Clark Lake Outflow May 24) & DOC & 0.6281 & 0.0025 & 3730 & 30 & -28.49 & -376.2 & 224.4 \\
\hline 78143 & Greenland21 (G21) (O glacier floodplain May 24) & DOC & 1.0074 & 0.0033 & $>$ Mod & & -25.94 & 0.4 & 139.4 \\
\hline 78140 & Greenladn 5 (G5) (N outflow May 19 12:41 GRT) & DOC & 0.7594 & 0.0028 & 2210 & 30 & -25.83 & -245.9 & 42.2 \\
\hline 78144 & Greenland40 (G40) (Tarn May 29) & DOC & 1.0442 & 0.004 & $>$ Mod & & -23.02 & 36.9 & 369.9 \\
\hline 78145 & Greenland53 (G53) (Clark Lake June 1) & DOC & 0.7362 & 0.0029 & 2460 & 30 & -28.18 & -269 & 67.5 \\
\hline 78146 & Greenland63 (G63) (N outflow July 12 6:00 GRT) & DOC & 0.6033 & 0.0039 & 4060 & 50 & -25.86 & -400.9 & 12.9 \\
\hline 78147 & Greenland68 (G68) ( $N$ outflow July 14 18:00 GRT) & DOC & 0.609 & 0.0047 & 3980 & 60 & -23.73 & -395.3 & 13 \\
\hline 78148 & Greenland72 (G72) (Fjord Water in Plume July 19) & DOC & 0.7914 & 0.0029 & 1880 & 30 & -21.2 & -214.1 & 47.5 \\
\hline \multicolumn{10}{|c|}{2008 MARGIN \& 2010 LAKE POC SAMPLES } \\
\hline Receipt \# & Sample & Type & F Modern & Fm Err & Age & Age Err & $\delta 13 \mathrm{C}$ & $\Delta \mathbf{1 4 C}$ & POC Conc $(\mathrm{mg} / \mathrm{L})$ \\
\hline 83674 & SL-2010-POC (South Lake July 62010 21:00 GRT) & Sediment OC & 0.8932 & 0.006 & 905 & 55 & -24.82 & -113.3 & Not Measured \\
\hline 83673 & NNL-2010-POC (North Lake July 32010 14:15 GRT) & Sediment OC & 0.8972 & 0.0066 & 870 & 60 & -26.96 & |-109.41 & Not Measured \\
\hline 79866 & G15 TOC-POC & \begin{tabular}{|l|} 
Sediment OC \\
\end{tabular} & 0.653 & 0.0046 & 3420 & 55 & -26.53 & -351.7 & below detection limit \\
\hline 79873 & G72 TOC-POC & Sediment OC & 0.8995 & 0.0025 & 850 & 20 & -23.87 & -107 & 12.07 \\
\hline 79874 & MF2 TOC-POC & Sediment OC & 0.8935 & 0.0024 & 905 & 20 & -22.18 & -113 & Not Measured \\
\hline 79865 & G5 TOC-POC & Sediment OC & 0.7481 & 0.0028 & 2330 & 30 & -26.41 & -257.1 & 518.9 \\
\hline 79867 & G20 TOC-POC & Sediment OC & 0.8085 & 0.0032 & 1710 & 30 & -25.91 & -197.2 & 48.03 \\
\hline 79868 & G21 TOC-POC & Sediment OC & 0.696 & 0.0037 & 2910 & 40 & -24.99 & -308.8 & below detection limit \\
\hline 79869 & G40 TOC-POC & Sediment OC & 1.0404 & 0.0032 & $>$ Mod & & -21.69 & 33.1 & 50.21 \\
\hline 79870 & G53 TOC-POC & Sediment OC & 0.7534 & 0.0034 & 2270 & 35 & -26.02 & -251.9 & 171.3 \\
\hline 79871 & G63 TOC-POC & Sediment OC & 0.7426 & 0.0029 & 2390 & 30 & -26.29 & -262.6 & 223.6 \\
\hline 79872 & G68 TOC-POC & Sediment OC & 0.7487 & 0.0032 & 2320 & 35 & -26.11 & -256.5 & 270.6 \\
\hline \multicolumn{10}{|c|}{2010 LAKE DIC SAMPLES - Taken in plastic bottles, seems like plastic is leaching some 14C dead material; NOT USABLE } \\
\hline Receipt \# & Sample & Type & F Modern & Fm Err & Age & Age Err & $\delta 13 \mathrm{C}$ & $\Delta 14 \mathrm{C}$ & \\
\hline 82409 & NNL DIC1, & DIC & 0.9103 & 0.002 & 755 & 20 & -13.91 & -96.24 & \\
\hline 82410 & NNL DIC2, & DIC & 0.9134 & 0.0025 & 725 & 20 & -14.67 & -93.16 & \\
\hline 82411 & SL DIC1, & DIC & \begin{tabular}{|c|}
0.8912 \\
\end{tabular} & 0.0022 & 925 & 20 & -14.42 & -115.21 & \\
\hline
\end{tabular}




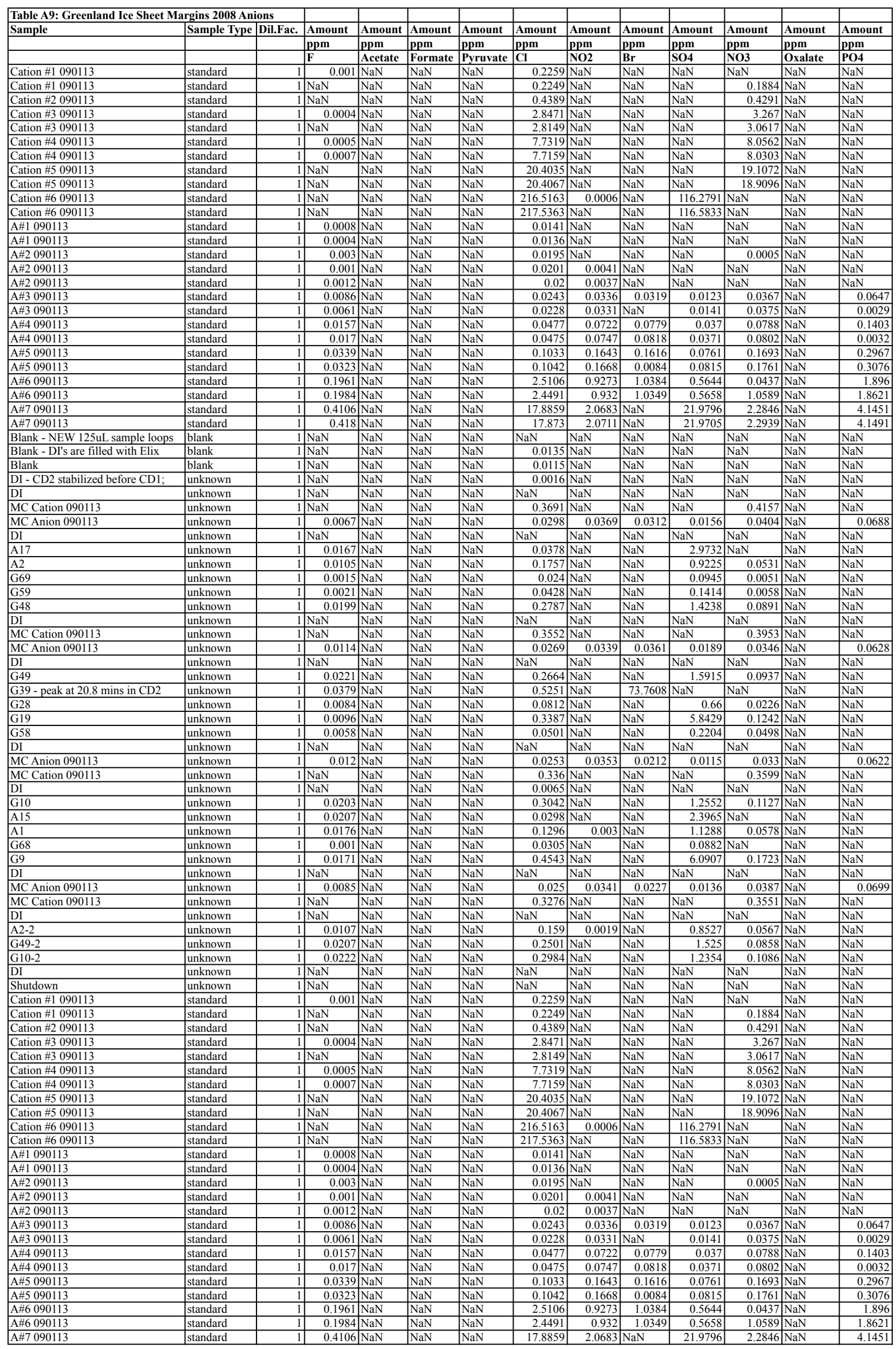




\begin{tabular}{|c|c|c|c|}
\hline Sample & Sample Type & Dil.Fac. & Amount \\
\hline & & & $\mathbf{F}$ \\
\hline A\#7 090113 & standard & 1 & 0.418 \\
\hline Blank - NEW 125uL sample loops & blank & & $\mathrm{NaN}$ \\
\hline Blank & blank & & $\mathrm{NaN}$ \\
\hline DI - CD2 stabilized before CD1; & unknown & & $\mathrm{NaN}$ \\
\hline DI & unknown & & $\mathrm{NaN}$ \\
\hline MC Cation 090113 & unknown & & $\mathrm{NaN}$ \\
\hline G27 & unknown & & 0.0096 \\
\hline G18 & unknown & & 0.0175 \\
\hline $\mathrm{A} 13$ & unknown & 1 & 0.0163 \\
\hline G67 & unknown & & 0.0209 \\
\hline G65 & unknown & & 0.0054 \\
\hline DI & unknown & & $\mathrm{NaN}$ \\
\hline MC Cation 090113 & unknown & & $\mathrm{NaN}$ \\
\hline G26B & unknown & & $\mathrm{NaN}$ \\
\hline G17 & unknown & & 0.018 \\
\hline MQ & unknown & & $\mathrm{NaN}$ \\
\hline DI & unknown & & $\mathrm{NaN}$ \\
\hline MC Anion 090113 & unknown & & 0.0116 \\
\hline MC Cation 090113 & unknown & & $\mathrm{NaN}$ \\
\hline DI & unknown & & $\mathrm{NaN}$ \\
\hline G8 & unknown & 1 & 0.0228 \\
\hline $\mathrm{A} 12$ & unknown & & 0.0224 \\
\hline G66 & unknown & & 0.0059 \\
\hline G56 & unknown & & 0.0064 \\
\hline G46 & unknown & 1 & 0.0025 \\
\hline $\mathrm{G} 45$ & unknown & & 0.0108 \\
\hline DI & unknown & & $\mathrm{NaN}$ \\
\hline MC Anion 090113 & unknown & 1 & 0.012 \\
\hline \begin{tabular}{|l|l} 
MC Cation 090113 \\
\end{tabular} & unknown & & $\mathrm{NaN}$ \\
\hline DI & unknown & & $\mathrm{NaN}$ \\
\hline \begin{tabular}{|l} 
Shutdown \\
\end{tabular} & unknown & & $\mathrm{NaN}$ \\
\hline Cation \#1 090113 & standard & & 0.001 \\
\hline Cation \#1 090113 & standard & & $\mathrm{NaN}$ \\
\hline Cation \#2 090113 & standard & & $\mathrm{NaN}$ \\
\hline Cation \#3 090113 & standard & 1 & 0.0004 \\
\hline Cation \#3 090113 & standard & & $\mathrm{NaN}$ \\
\hline Cation \#4 090113 & standard & & 0.0005 \\
\hline Cation \#4 090113 & standard & & 0.0007 \\
\hline \begin{tabular}{|l} 
Cation \#5 090113 \\
\end{tabular} & standard & & $\mathrm{NaN}$ \\
\hline \begin{tabular}{|l} 
Cation \#5 090113 \\
\end{tabular} & standard & & $\mathrm{NaN}$ \\
\hline \begin{tabular}{|l} 
Cation \#6 090113 \\
\end{tabular} & standard & & $\mathrm{NaN}$ \\
\hline Cation \#6 090113 & standard & & $\mathrm{NaN}$ \\
\hline A\#1 090113 & standard & & 0.0008 \\
\hline A\#1 090113 & standard & & 0.0004 \\
\hline A\#2 090113 & standard & & 0.003 \\
\hline A\#2 090113 & standard & 1 & 0.001 \\
\hline A\#2 090113 & standard & & 0.0012 \\
\hline A\#3 090113 & standard & 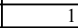 & 0.0086 \\
\hline A\#3 090113 & standard & & 0.0061 \\
\hline A\#4 090113 & standard & & 0.0157 \\
\hline A\#4 090113 & standard & & 0.017 \\
\hline A\#5090113 & standard & & 0.0339 \\
\hline A\#5 090113 & standard & & 0.0323 \\
\hline A\#6090113 & standard & & 0.1961 \\
\hline A\#6 090113 & standard & & 0.1984 \\
\hline A\#7 090113 & standard & & 0.4106 \\
\hline A\#7 090113 & standard & & 0.418 \\
\hline Blank - NEW 125uL sample loops & blank & & $\mathrm{NaN}$ \\
\hline Blank - DI's are filled with Elix & blank & & $\mathrm{NaN}$ \\
\hline
\end{tabular}




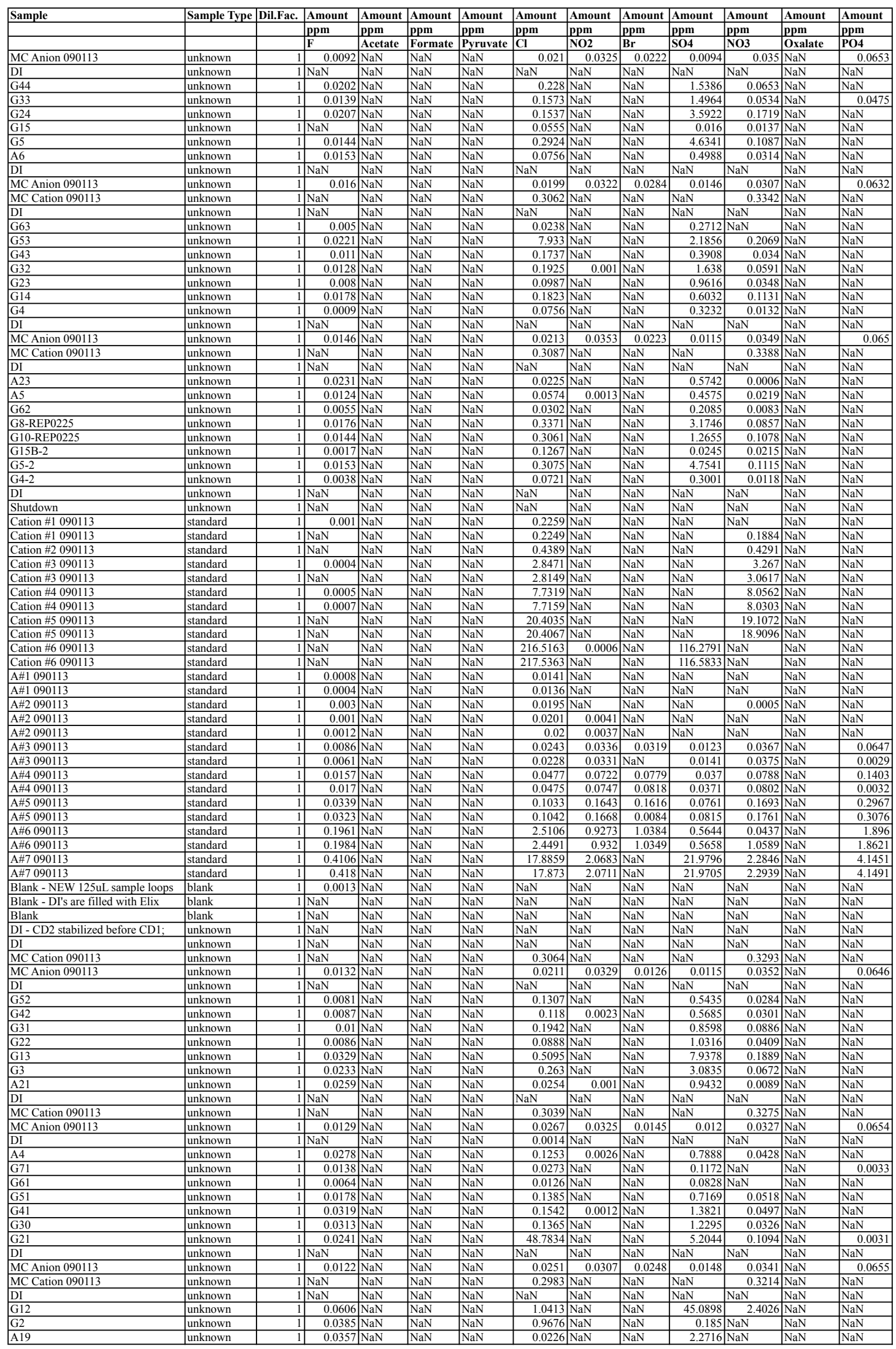




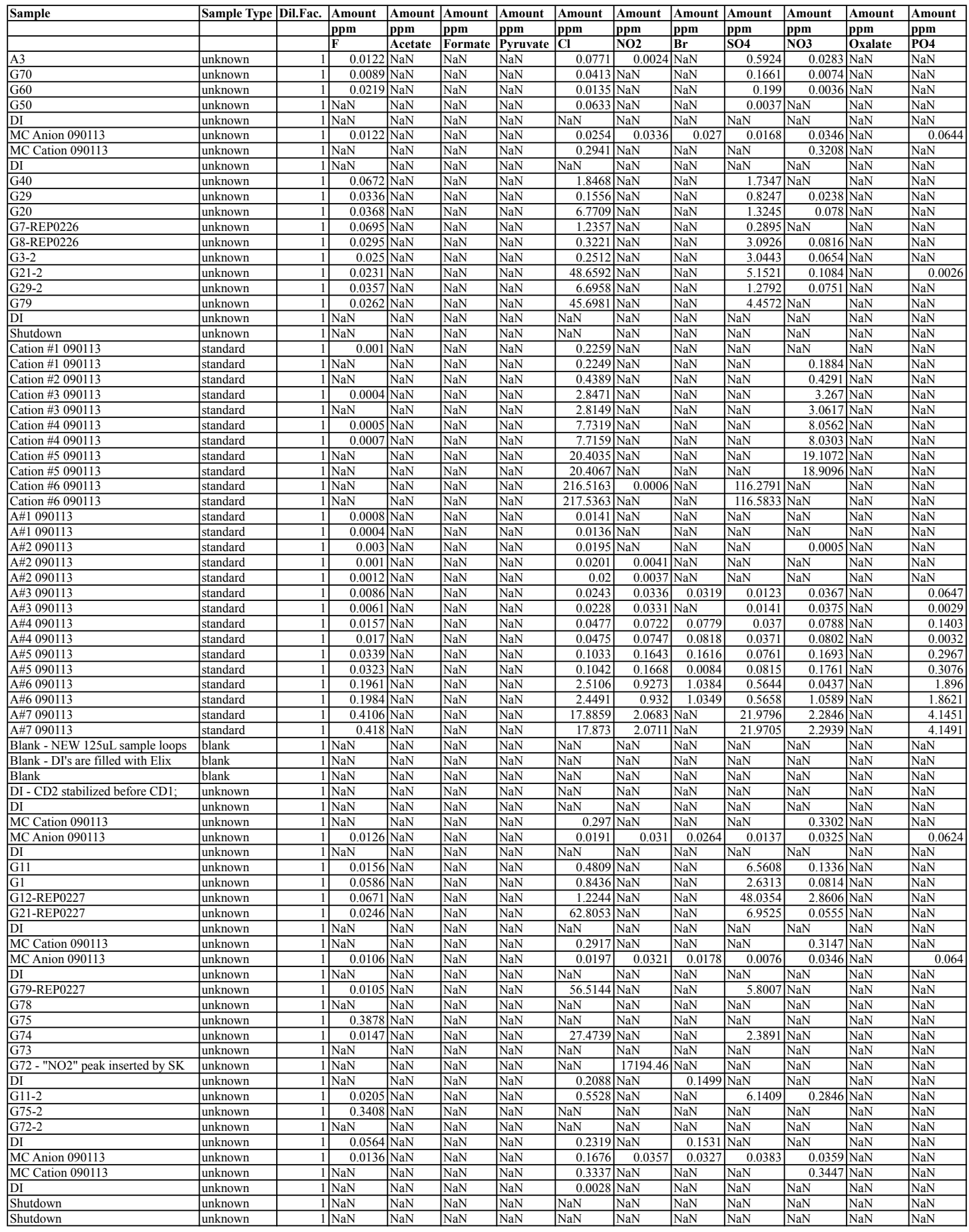




\begin{tabular}{|c|c|c|c|}
\hline Table A10: Greenland Ice Sheet 1 & 08 Cati & & \\
\hline Sample & Sample Type & Dil.Fac. & Amount \\
\hline & & & ppm \\
\hline & & & $\mathbf{L i}$ \\
\hline Cation \#1 090113 & standard & 1 & 0.0017 \\
\hline Cation \#1 090113 & standard & 1 & 0.0017 \\
\hline Cation \#2 090113 & standard & 1 & 0.0034 \\
\hline Cation \#3 090113 & standard & 1 & 0.0197 \\
\hline Cation \#3 090113 & standard & 1 & 0.0197 \\
\hline Cation \#4 090113 & standard & 1 & 0.0496 \\
\hline Cation \#4 090113 & standard & 1 & 0.0497 \\
\hline Cation \#5 090113 & standard & 1 & 0.1254 \\
\hline Cation \#5 090113 & standard & 1 & 0.1257 \\
\hline Cation \#6 090113 & standard & 1 & 1.3017 \\
\hline Cation \#6 090113 & standard & 1 & 1.2884 \\
\hline A\#1 090113 & standard & & $\mathrm{NaN}$ \\
\hline A\#1 090113 & standard & & $\mathrm{NaN}$ \\
\hline A\#2 090113 & standard & & $\mathrm{NaN}$ \\
\hline A\#2 090113 & standard & & $\mathrm{NaN}$ \\
\hline A\#2 090113 & standard & & $\mathrm{NaN}$ \\
\hline A\#3 090113 & standard & & $\mathrm{NaN}$ \\
\hline A\#3 090113 & standard & & $\mathrm{NaN}$ \\
\hline A\#4 090113 & standard & & $\mathrm{NaN}$ \\
\hline A\#4 090113 & standard & & $\mathrm{NaN}$ \\
\hline A\#5 090113 & standard & & $\mathrm{NaN}$ \\
\hline A\#5 090113 & standard & & $\mathrm{NaN}$ \\
\hline A\#6 090113 & standard & & $\mathrm{NaN}$ \\
\hline A\#6 090113 & standard & & $\mathrm{NaN}$ \\
\hline A\#7 090113 & standard & & $\mathrm{NaN}$ \\
\hline A\#7 090113 & standard & & $\mathrm{NaN}$ \\
\hline Blank - NEW 125uL sample loops & blank & & $\mathrm{NaN}$ \\
\hline Blank - DI's are filled with Elix & blank & & $\mathrm{NaN}$ \\
\hline Blank & blank & & $\mathrm{NaN}$ \\
\hline DI - CD2 stabilized before CD1; & unknown & & $\mathrm{NaN}$ \\
\hline DI & unknown & & $\mathrm{NaN}$ \\
\hline MC Cation 090113 & unknown & 1 & 0.0039 \\
\hline MC Anion 090113 & unknown & & $\mathrm{NaN}$ \\
\hline DI & unknown & & $\mathrm{NaN}$ \\
\hline A17 & unknown & 1 & 0.0016 \\
\hline $\mathrm{A} 2$ & unknown & 1 & 0.0009 \\
\hline G69 & unknown & 1 & 0.0003 \\
\hline G59 & unknown & 1 & 0.0004 \\
\hline G48 & unknown & 1 & 0.0013 \\
\hline DI & unknown & & $\mathrm{NaN}$ \\
\hline MC Cation 090113 & unknown & 1 & 0.0039 \\
\hline MC Anion 090113 & unknown & & $\mathrm{NaN}$ \\
\hline DI & unknown & & $\mathrm{NaN}$ \\
\hline G49 & unknown & 1 & 0.0012 \\
\hline G39 - peak at 20.8 mins in CD2 & unknown & 1 & 0.0025 \\
\hline G28 & unknown & 1 & 0.0004 \\
\hline G19 & unknown & 1 & 0.0012 \\
\hline G58 & unknown & 1 & 0.0005 \\
\hline DI & unknown & & $\mathrm{NaN}$ \\
\hline MC Anion 090113 & unknown & & $\mathrm{NaN}$ \\
\hline MC Cation 090113 & unknown & 1 & 0.0039 \\
\hline DI & unknown & & $\mathrm{NaN}$ \\
\hline G10 & unknown & 1 & 0.0009 \\
\hline A15 & unknown & 1 & 0.0015 \\
\hline $\mathrm{A} 1$ & unknown & 1 & 0.0009 \\
\hline G68 & unknown & 1 & 0.0002 \\
\hline G9 & unknown & 1 & 0.0014 \\
\hline DI & unknown & & $\mathrm{NaN}$ \\
\hline MC Anion 090113 & unknown & & $\mathrm{NaN}$ \\
\hline MC Cation 090113 & unknown & 1 & 0.0039 \\
\hline DI & unknown & & $\mathrm{NaN}$ \\
\hline A2-2 & unknown & 1 & 0.0009 \\
\hline G49-2 & unknown & 1 & 0.0012 \\
\hline G10-2 & unknown & 1 & 0.0009 \\
\hline DI & unknown & & $\mathrm{NaN}$ \\
\hline \begin{tabular}{|l} 
Shutdown \\
\end{tabular} & unknown & & $\mathrm{NaN}$ \\
\hline Cation \#1090113 & standard & 1 & 0.0017 \\
\hline Cation \#1090113 & standard & 1 & 0.0017 \\
\hline Cation \#2 090113 & standard & 1 & 0.0034 \\
\hline Cation \#3 090113 & standard & 1 & 0.0197 \\
\hline Cation \#3 090113 & standard & 1 & 0.0197 \\
\hline Cation \#4 090113 & standard & 1 & 0.0496 \\
\hline Cation \#4 090113 & standard & 1 & 0.0497 \\
\hline Cation \#5 090113 & standard & 1 & 0.1254 \\
\hline Cation \#5 090113 & standard & 1 & 0.1257 \\
\hline Cation \#6090113 & standard & 1 & 1.3017 \\
\hline Cation \#6 090113 & standard & 1 & 1.2884 \\
\hline A\#1 090113 & standard & & $\mathrm{NaN}$ \\
\hline A\#1 090113 & standard & & $\mathrm{NaN}$ \\
\hline A\#2 090113 & standard & & $\mathrm{NaN}$ \\
\hline A\#2 090113 & standard & & $\mathrm{NaN}$ \\
\hline A\#2 090113 & standard & & $\mathrm{NaN}$ \\
\hline A\#3 090113 & standard & & $\mathrm{NaN}$ \\
\hline A\#3 090113 & standard & & $\mathrm{NaN}$ \\
\hline A\#4 090113 & standard & & $\mathrm{NaN}$ \\
\hline A\#4 090113 & standard & & $\mathrm{NaN}$ \\
\hline A\#5 090113 & standard & & $\mathrm{NaN}$ \\
\hline A\#5 090113 & standard & & $\mathrm{NaN}$ \\
\hline A\#6 090113 & standard & & $\mathrm{NaN}$ \\
\hline A\#6 090113 & standard & & $\mathrm{NaN}$ \\
\hline A\#7 090113 & standard & & $\mathrm{NaN}$ \\
\hline
\end{tabular}




\begin{tabular}{|c|c|c|c|}
\hline Sample & Sample Type & Dil.Fac. & Amount \\
\hline & & & ppm \\
\hline & & & Li \\
\hline A\#7 090113 & standard & & $\mathrm{NaN}$ \\
\hline Blank - NEW 125uL sample loops & blank & & $\mathrm{NaN}$ \\
\hline Blank - DI's are filled with Elix & blank & & $\mathrm{NaN}$ \\
\hline Blank & blank & & $\mathrm{NaN}$ \\
\hline DI - CD2 stabilized before CD1; & unknown & & $\mathrm{NaN}$ \\
\hline DI & unknown & & $\mathrm{NaN}$ \\
\hline MC Cation 090113 & unknown & 1 & 0.004 \\
\hline MC Anion 090113 & unknown & & $\mathrm{NaN}$ \\
\hline DI & unknown & & $\mathrm{NaN}$ \\
\hline G38 & unknown & 1 & 0.0008 \\
\hline G27 & unknown & 1 & 0.0013 \\
\hline G18 & unknown & 1 & 0.0013 \\
\hline $\mathrm{A} 13$ & unknown & 1 & 0.0008 \\
\hline G67 & unknown & 1 & 0.0015 \\
\hline G65 & unknown & 1 & 0.0003 \\
\hline DI & unknown & 1 & $\mathrm{NaN}$ \\
\hline MC Cation 090113 & unknown & 1 & 0.004 \\
\hline MC Anion 090113 & unknown & & $\mathrm{NaN}$ \\
\hline DI & unknown & & $\mathrm{NaN}$ \\
\hline G57 & unknown & 1 & 0.0004 \\
\hline G47 & unknown & 1 & 0.0012 \\
\hline G37 & unknown & 1 & 0.0017 \\
\hline G26B & unknown & & $\mathrm{NaN}$ \\
\hline G17 & unknown & 1 & 0.0013 \\
\hline $\mathrm{MQ}$ & unknown & & $\mathrm{NaN}$ \\
\hline DI & unknown & & $\mathrm{NaN}$ \\
\hline MC Anion 090113 & unknown & & $\mathrm{NaN}$ \\
\hline MC Cation 090113 & unknown & & 0.004 \\
\hline DI & unknown & 1 & $\mathrm{NaN}$ \\
\hline G8 & unknown & 1 & 0.001 \\
\hline $\mathrm{A} 12$ & unknown & 1 & 0.0015 \\
\hline G66 & unknown & 1 & 0.0003 \\
\hline G56 & unknown & 1 & 0.0004 \\
\hline G46 & unknown & & $\mathrm{NaN}$ \\
\hline G45 & unknown & 1 & 0.0009 \\
\hline DI & unknown & & $\mathrm{NaN}$ \\
\hline MC Anion 090113 & unknown & & $\mathrm{NaN}$ \\
\hline MC Cation 090113 & unknown & 1 & 0.004 \\
\hline DI & unknown & & $\mathrm{NaN}$ \\
\hline G35 & unknown & 1 & 0.0021 \\
\hline G26 & unknown & & $\mathrm{NaN}$ \\
\hline G16 & unknown & 1 & 0.0014 \\
\hline G7 & unknown & 1 & 0.0011 \\
\hline $\mathrm{A} 11$ & unknown & 1 & 0.0013 \\
\hline G18-2 & unknown & 1 & 0.0014 \\
\hline G8-2 & unknown & 1 & 0.001 \\
\hline G7-2 & unknown & 1 & 0.0011 \\
\hline MQ-2 & unknown & & $\mathrm{NaN}$ \\
\hline DI & unknown & & $\mathrm{NaN}$ \\
\hline \begin{tabular}{|l} 
Shutdown \\
\end{tabular} & unknown & & $\mathrm{NaN}$ \\
\hline \begin{tabular}{|l|l} 
Cation \#1 090113 \\
\end{tabular} & standard & 1 & 0.0017 \\
\hline Cation \#1 090113 & standard & 1 & 0.0017 \\
\hline Cation \#2 090113 & standard & 1 & 0.0034 \\
\hline Cation \#3 090113 & standard & 1 & 0.0197 \\
\hline Cation \#3 090113 & standard & 1 & 0.0197 \\
\hline Cation \#4 090113 & standard & 1 & 0.0496 \\
\hline Cation \#4 090113 & standard & 1 & 0.0497 \\
\hline \begin{tabular}{|c|} 
Cation \#5 090113 \\
\end{tabular} & standard & 1 & 0.1254 \\
\hline Cation \#5 090113 & standard & & 0.1257 \\
\hline Cation \#6 090113 & standard & 1 & 1.3017 \\
\hline Cation \#6 090113 & standard & 1 & 1.2884 \\
\hline A\#1 090113 & standard & & $\mathrm{NaN}$ \\
\hline A\#1 090113 & standard & & $\mathrm{NaN}$ \\
\hline A\#2 090113 & standard & & $\mathrm{NaN}$ \\
\hline A\#2 090113 & standard & & $\mathrm{NaN}$ \\
\hline A\#2 090113 & standard & & $\mathrm{NaN}$ \\
\hline A\#3 090113 & standard & & $\mathrm{NaN}$ \\
\hline A\#3 090113 & standard & & $\mathrm{NaN}$ \\
\hline A\#4 090113 & standard & & $\mathrm{NaN}$ \\
\hline A\#4 090113 & standard & & $\mathrm{NaN}$ \\
\hline A\#5 090113 & standard & & $\mathrm{NaN}$ \\
\hline A\#5 090113 & standard & & $\mathrm{NaN}$ \\
\hline A\#6 090113 & standard & & $\mathrm{NaN}$ \\
\hline A\#6 090113 & standard & & $\mathrm{NaN}$ \\
\hline A\#7 090113 & standard & & $\mathrm{NaN}$ \\
\hline A\#7 090113 & standard & & $\mathrm{NaN}$ \\
\hline Blank - NEW 125uL sample loops & blank & & $\mathrm{NaN}$ \\
\hline Blank - DI's are filled with Elix & blank & & $\mathrm{NaN}$ \\
\hline Blank & blank & & $\mathrm{NaN}$ \\
\hline DI - CD2 stabilized before CD1; & unknown & & $\mathrm{NaN}$ \\
\hline $\mathrm{DI}$ & unknown & & $\mathrm{NaN}$ \\
\hline MC Cation 090113 & unknown & 1 & 0.004 \\
\hline MC Anion 090113 & unknown & & $\mathrm{NaN}$ \\
\hline $\mathrm{DI}$ & unknown & & $\mathrm{NaN}$ \\
\hline G34 & unknown & 1 & 0.0013 \\
\hline G25 & unknown & 1 & 0.0008 \\
\hline G15B & unknown & & $\mathrm{NaN}$ \\
\hline G6 & unknown & 1 & 0.0013 \\
\hline A9 & unknown & 1 & 0.0012 \\
\hline G64 & unknown & & 0.0003 \\
\hline $\mathrm{MQ}$ & unknown & & $\mathrm{NaN}$ \\
\hline MC Cation 090113 & unknown & 1 & 0.004 \\
\hline
\end{tabular}




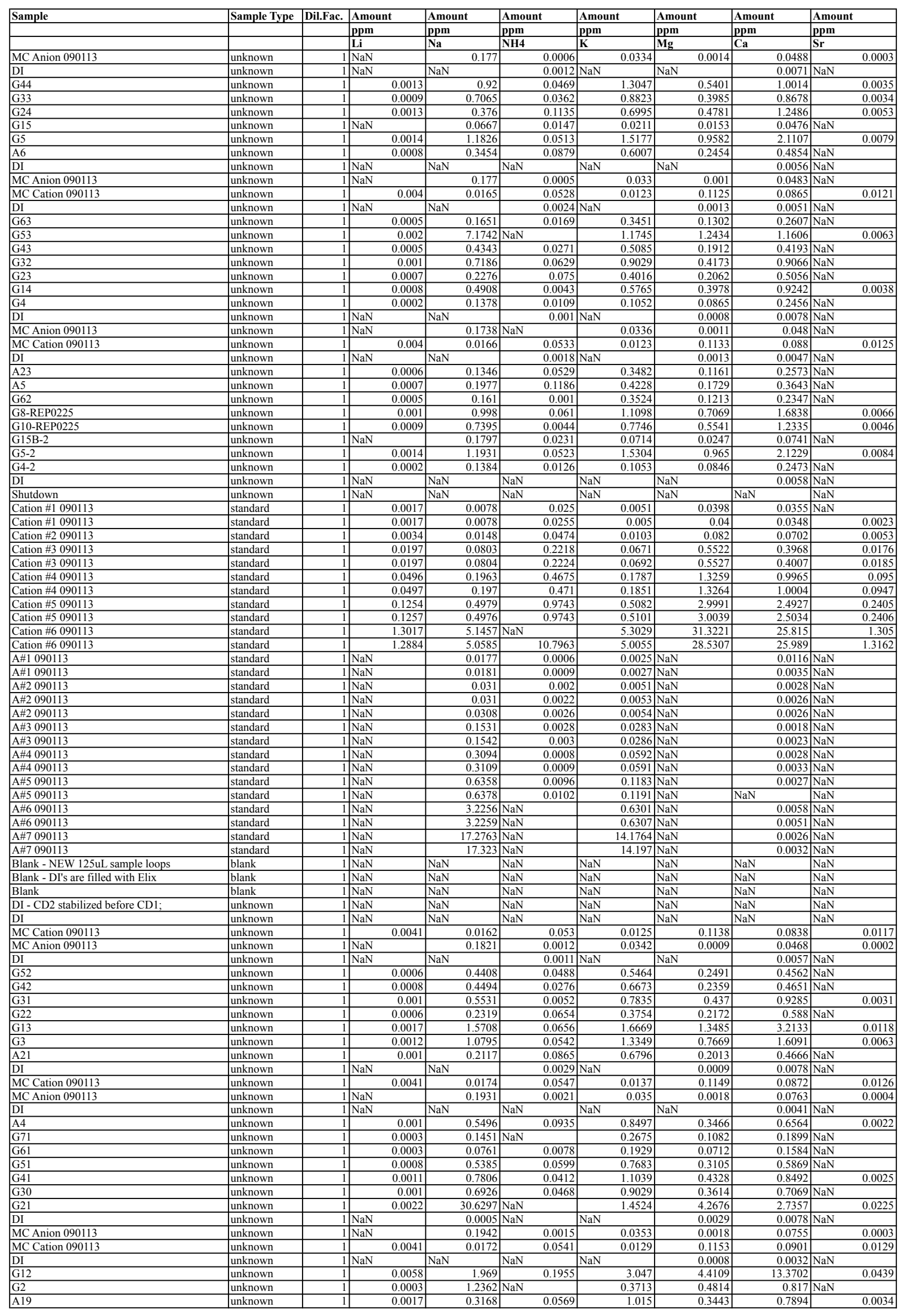




\begin{tabular}{|c|c|c|c|c|c|c|c|c|c|}
\hline Sample & Sample Type & Dil.Fac. & Amount & Amount & Amount & Amount & Amount & Amount & Amount \\
\hline & & & ppm & ppm & ppm & ppm & ppm & ppm & ppm \\
\hline & & & Li & $\mathrm{Na}$ & NH4 & $\mathrm{K}$ & $\mathrm{Mg}$ & $\mathrm{Ca}$ & $\mathrm{Sr}$ \\
\hline $\mathrm{A} 3$ & unknown & 1 & 0.0008 & 0.3095 & 0.1087 & 0.5445 & 0.2346 & 0.4887 & 0.0012 \\
\hline G70 & unknown & 1 & 0.0005 & 0.2256 & $\mathrm{NaN}$ & 0.345 & \begin{tabular}{l|l}
0.1465 \\
\end{tabular} & 0.3595 & $\mathrm{NaN}$ \\
\hline G60 & unknown & 1 & 0.0004 & 0.0934 & 0.0175 & 0.2911 & 0.1211 & 0.2889 & $\mathrm{NaN}$ \\
\hline \begin{tabular}{|l|} 
G50 \\
\end{tabular} & unknown & & $\mathrm{NaN}$ & 0.1108 & 0.0115 & 0.058 & $\begin{array}{ll}0.0066 \\
\end{array}$ & 0.0202 & $\mathrm{NaN}$ \\
\hline DI & unknown & & $\mathrm{NaN}$ & $\mathrm{NaN}$ & $\mathrm{NaN}$ & $\mathrm{NaN}$ & $\mathrm{NaN}$ & 0.0046 & $\mathrm{NaN}$ \\
\hline MC Anion 090113 & unknown & 1 & $\mathrm{NaN}$ & 0.1951 & 0.0015 & 0.0358 & 0.0015 & 0.0755 & $\mathrm{NaN}$ \\
\hline MC Cation 090113 & unknown & 1 & 0.0041 & 0.0173 & 0.0545 & 0.0127 & 0.116 & 0.0905 & 0.0125 \\
\hline DI & unknown & 1 & $\mathrm{NaN}$ & $\mathrm{NaN}$ & $\mathrm{NaN}$ & $\mathrm{NaN}$ & 0.0012 & 0.0036 & $\mathrm{NaN}$ \\
\hline G40 & unknown & 1 & 0.0005 & 1.9547 & 0.0064 & 1.7103 & 1.3465 & 2.0146 & 0.0115 \\
\hline \begin{tabular}{|l|} 
G29 \\
\end{tabular} & unknown & 1 & 0.0007 & 0.5842 & 0.0372 & 0.7004 & 0.2797 & 0.5704 & $\mathrm{NaN}$ \\
\hline \begin{tabular}{|l|} 
G20 \\
\end{tabular} & unknown & 1 & 0.0016 & 6.0721 & $\mathrm{NaN}$ & 0.9057 & 1.0162 & 0.9272 & \begin{tabular}{ll|l}
0.0067 \\
\end{tabular} \\
\hline \begin{tabular}{|l|} 
G7-REP0226 \\
\end{tabular} & unknown & 1 & 0.0011 & 1.5991 & $\mathrm{NaN}$ & 0.6061 & 0.7494 & 0.9112 & $\mathrm{NaN}$ \\
\hline G8-REP0226 & unknown & 1 & 0.0011 & 1.0294 & 0.0781 & 1.142 & 0.7332 & 1.7504 & 0.0064 \\
\hline G3-2 & unknown & 1 & 0.0012 & 1.082 & 0.0522 & 1.3451 & \begin{tabular}{l|}
0.7707 \\
\end{tabular} & 1.6182 & 0.0106 \\
\hline $\mathrm{G} 21-2$ & unknown & 1 & 0.0022 & 30.6841 & $\mathrm{NaN}$ & 1.4572 & 4.2814 & 2.7464 & 0.0228 \\
\hline G29-2 & unknown & 1 & 0.0016 & 6.0753 & $\mathrm{NaN}$ & 0.9056 & 1.0234 & 0.9387 & 0.005 \\
\hline \begin{tabular}{|l|} 
G79 \\
\end{tabular} & unknown & 1 & 0.0007 & 27.3086 & $\mathrm{NaN}$ & 1.0466 & 4.2591 & 2.1144 & 0.0146 \\
\hline DI & unknown & & $\mathrm{NaN}$ & 0.0008 & $\mathrm{NaN}$ & $\mathrm{NaN}$ & 0.0039 & 0.0092 & $\mathrm{NaN}$ \\
\hline \begin{tabular}{|l} 
Shutdown \\
\end{tabular} & unknown & 1 & $\mathrm{NaN}$ & $\mathrm{NaN}$ & $\mathrm{NaN}$ & $\mathrm{NaN}$ & $\mathrm{NaN}$ & $\mathrm{NaN}$ & $\mathrm{NaN}$ \\
\hline Cation \#1 090113 & standard & 1 & 0.0017 & 0.0078 & 0.025 & 0.0051 & 0.0398 & 0.0355 & $\mathrm{NaN}$ \\
\hline Cation \#1 090113 & standard & 1 & 0.0017 & 0.0078 & 0.0255 & 0.005 & 0.04 & 0.0348 & 0.0023 \\
\hline Cation \#2 090113 & standard & 1 & 0.0034 & 0.0148 & 0.0474 & \begin{tabular}{l|l}
0.0103 \\
\end{tabular} & 0.082 & 0.0702 & 0.0053 \\
\hline Cation \#3 090113 & standard & 1 & 0.0197 & 0.0803 & 0.2218 & 0.0671 & 0.5522 & 0.3968 & 0.0176 \\
\hline Cation \#3 090113 & standard & 1 & 0.0197 & 0.0804 & 0.2224 & \begin{tabular}{l|l}
0.0692 \\
\end{tabular} & 0.5527 & 0.4007 & 0.0185 \\
\hline Cation \#4 090113 & standard & 1 & 0.0496 & $\begin{array}{ll}0.1963 \\
\end{array}$ & 0.4675 & \begin{tabular}{l|}
0.1787 \\
\end{tabular} & 1.3259 & 0.9965 & 0.095 \\
\hline Cation \#4 090113 & standard & 1 & 0.0497 & 0.197 & 0.471 & 0.1851 & 1.3264 & 1.0004 & 0.0947 \\
\hline Cation \#5 090113 & standard & 1 & 0.1254 & \begin{tabular}{l|l}
0.4979 \\
\end{tabular} & 0.9743 & 0.5082 & 2.9991 & 2.4927 & 0.2405 \\
\hline Cation \#5 090113 & standard & 1 & 0.1257 & $\begin{array}{ll}0.4976 \\
\end{array}$ & 0.9743 & 0.5101 & 3.0039 & 2.5034 & 0.2406 \\
\hline Cation \#6 090113 & standard & 1 & 1.3017 & 5.1457 & $\mathrm{NaN}$ & 5.3029 & 31.3221 & 25.815 & 1.305 \\
\hline Cation \#6 090113 & standard & 1 & 1.2884 & 5.0585 & 10.7963 & 5.0055 & 28.5307 & 25.989 & 1.3162 \\
\hline A\#1 090113 & standard & & $\mathrm{NaN}$ & 0.0177 & 0.0006 & \begin{tabular}{l|l}
0.0025 \\
\end{tabular} & \begin{tabular}{|l|l|}
$\mathrm{NaN}$ \\
\end{tabular} & 0.0116 & $\mathrm{NaN}$ \\
\hline A\#1 090113 & standard & & $\mathrm{NaN}$ & 0.0181 & 0.0009 & 0.0027 & $\mathrm{NaN}$ & 0.0035 & $\mathrm{NaN}$ \\
\hline A\#2 090113 & standard & & $\mathrm{NaN}$ & 0.031 & 0.002 & 0.0051 & $\mathrm{NaN}$ & 0.0028 & $\mathrm{NaN}$ \\
\hline A\#2 090113 & standard & & $\mathrm{NaN}$ & 0.031 & 0.0022 & 0.0053 & $\mathrm{NaN}$ & 0.0026 & $\mathrm{NaN}$ \\
\hline A\#2 090113 & standard & & $\mathrm{NaN}$ & 0.0308 & 0.0026 & \begin{tabular}{l|l}
0.0054 \\
\end{tabular} & $\mathrm{NaN}$ & $\begin{array}{ll}0.0026 \\
\end{array}$ & $\mathrm{NaN}$ \\
\hline A\#3 090113 & standard & & $\mathrm{NaN}$ & 0.1531 & 0.0028 & \begin{tabular}{l|l|}
0.0283 \\
\end{tabular} & $\mathrm{NaN}$ & 0.0018 & $\mathrm{NaN}$ \\
\hline A\#3 090113 & standard & & $\mathrm{NaN}$ & 0.1542 & 0.003 & \begin{tabular}{l|l}
0.0286 \\
\end{tabular} & $\mathrm{NaN}$ & 0.0023 & $\mathrm{NaN}$ \\
\hline A\#4 090113 & standard & & $\mathrm{NaN}$ & 0.3094 & 0.0008 & $\begin{array}{ll}0.0592 \\
\end{array}$ & $\mathrm{NaN}$ & 0.0028 & $\mathrm{NaN}$ \\
\hline A\#4 090113 & standard & & $\mathrm{NaN}$ & 0.3109 & 0.0009 & $\begin{array}{ll}0.0591 \\
\end{array}$ & $\mathrm{NaN}$ & 0.0033 & $\mathrm{NaN}$ \\
\hline A\#5 090113 & standard & & $\mathrm{NaN}$ & 0.6358 & 0.0096 & 0.1183 & $\mathrm{NaN}$ & 0.0027 & $\mathrm{NaN}$ \\
\hline A\#5 090113 & standard & & $\mathrm{NaN}$ & \begin{tabular}{l|l}
0.6378 \\
\end{tabular} & 0.0102 & 0.1191 & $\mathrm{NaN}$ & $\mathrm{NaN}$ & $\mathrm{NaN}$ \\
\hline A\#6 090113 & standard & & $\mathrm{NaN}$ & 3.2256 & $\mathrm{NaN}$ & 0.6301 & $\mathrm{NaN}$ & 0.0058 & $\mathrm{NaN}$ \\
\hline A\#6 090113 & standard & & $\mathrm{NaN}$ & 3.2259 & $\mathrm{NaN}$ & $\begin{array}{l}0.6307 \\
\end{array}$ & $\mathrm{NaN}$ & 0.0051 & $\mathrm{NaN}$ \\
\hline A\#7 090113 & standard & & $\mathrm{NaN}$ & 17.2763 & $\mathrm{NaN}$ & 14.1764 & $\mathrm{NaN}$ & 0.0026 & $\mathrm{NaN}$ \\
\hline A\#7 090113 & standard & & $\mathrm{NaN}$ & 17.323 & $\mathrm{NaN}$ & 14.197 & $\mathrm{NaN}$ & 0.0032 & $\mathrm{NaN}$ \\
\hline Blank - NEW 125uL sample loops & blank & & $\mathrm{NaN}$ & $\mathrm{NaN}$ & $\mathrm{NaN}$ & $\mathrm{NaN}$ & $\mathrm{NaN}$ & $\mathrm{NaN}$ & $\mathrm{NaN}$ \\
\hline Blank - DI's are filled with Elix & blank & & $\mathrm{NaN}$ & $\mathrm{NaN}$ & $\mathrm{NaN}$ & $\mathrm{NaN}$ & $\mathrm{NaN}$ & $\mathrm{NaN}$ & $\mathrm{NaN}$ \\
\hline Blank & blank & & NaN & $\mathrm{NaN}$ & $\mathrm{NaN}$ & $\mathrm{NaN}$ & $\mathrm{NaN}$ & $\mathrm{NaN}$ & $\mathrm{NaN}$ \\
\hline DI - CD2 stabilized before CD1; & unknown & & $\mathrm{NaN}$ & $\mathrm{NaN}$ & $\mathrm{NaN}$ & $\mathrm{NaN}$ & $\mathrm{NaN}$ & $\mathrm{NaN}$ & $\mathrm{NaN}$ \\
\hline DI & unknown & & $\mathrm{NaN}$ & $\mathrm{NaN}$ & $\mathrm{NaN}$ & $\mathrm{NaN}$ & $\mathrm{NaN}$ & 0.0042 & $\mathrm{NaN}$ \\
\hline MC Cation 090113 & unknown & 1 & 0.0042 & 0.0166 & 0.0544 & 0.0127 & 0.1182 & 0.088 & 0.0129 \\
\hline MC Anion 090113 & unknown & & $\mathrm{NaN}$ & 0.1801 & 0.0008 & 0.0336 & 0.0008 & 0.0117 & $\mathrm{NaN}$ \\
\hline DI & unknown & & $\mathrm{NaN}$ & $\mathrm{NaN}$ & $\mathrm{NaN}$ & $\mathrm{NaN}$ & $\mathrm{NaN}$ & 0.0043 & $\mathrm{NaN}$ \\
\hline G11 & unknown & 1 & 0.0015 & 1.5946 & 0.0485 & 1.6823 & 1.2541 & 2.9532 & 0.0111 \\
\hline G1 & unknown & 1 & 0.0028 & 2.9167 & 0.0037 & 2.8536 & 1.2571 & 4.1587 & 0.014 \\
\hline \begin{tabular}{|l|} 
G12-REP0227 \\
\end{tabular} & unknown & 1 & 0.0067 & 2.3031 & 0.2055 & 3.5714 & 5.0078 & 13.8287 & 0.0457 \\
\hline G21-REP0227 & unknown & 1 & 0.0028 & $\mathrm{NaN}$ & $\mathrm{NaN}$ & 1.869 & 5.2719 & 3.0047 & 0.0264 \\
\hline DI & unknown & & $\mathrm{NaN}$ & 0.0014 & $\mathrm{NaN}$ & $\mathrm{NaN}$ & 0.006 & 0.0127 & $\mathrm{NaN}$ \\
\hline MC Cation 090113 & unknown & 1 & 0.0041 & 0.0166 & 0.0541 & 0.0125 & 0.1188 & 0.0909 & 0.013 \\
\hline MC Anion 090113 & unknown & & $\mathrm{NaN}$ & 0.18 & 0.0009 & 0.0339 & 0.0016 & 0.0129 & $\mathrm{NaN}$ \\
\hline DI & unknown & & $\mathrm{NaN}$ & $\mathrm{NaN}$ & $\mathrm{NaN}$ & $\mathrm{NaN}$ & $\mathrm{NaN}$ & 0.0047 & $\mathrm{NaN}$ \\
\hline G79-REP0227 & unknown & 1 & 0.0009 & 33.3984 & $\mathrm{NaN}$ & 1.2131 & 5.2138 & 2.3752 & 0.0192 \\
\hline G78 & unknown & & $\mathrm{NaN}$ & $\mathrm{NaN}$ & $\mathrm{NaN}$ & 2380.4388 & $\mathrm{NaN}$ & $\mathrm{NaN}$ & 0.8091 \\
\hline G75 & unknown & & $\mathrm{NaN}$ & $\mathrm{NaN}$ & $\mathrm{NaN}$ & 1253.8129 & 0.5525 & $\mathrm{NaN}$ & 0.8054 \\
\hline \begin{tabular}{|l|} 
G74 \\
\end{tabular} & unknown & 1 & 0.001 & 16.3925 & $\mathrm{NaN}$ & 0.6642 & 2.2828 & 1.2206 & $\mathrm{NaN}$ \\
\hline G73 & unknown & & $\mathrm{NaN}$ & $\mathrm{NaN}$ & $\mathrm{NaN}$ & $\mathrm{NaN}$ & 215.6089 & $\mathrm{NaN}$ & 0.7601 \\
\hline G72 - "NO2" peak inserted by SK & unknown & & $\mathrm{NaN}$ & $\mathrm{NaN}$ & $\mathrm{NaN}$ & 1033.8447 & 76.8963 & $\mathrm{NaN}$ & 0.7725 \\
\hline DI & unknown & & $\mathrm{NaN}$ & 0.1354 & $\mathrm{NaN}$ & $\mathrm{NaN}$ & 0.0323 & $\mathrm{NaN}$ & $\mathrm{NaN}$ \\
\hline G11-2 & unknown & 1 & 0.0015 & 1.5121 & 0.017 & 1.582 & 1.1164 & 2.8042 & $\mathrm{NaN}$ \\
\hline G75-2 & unknown & & $\mathrm{NaN}$ & $\mathrm{NaN}$ & $\mathrm{NaN}$ & 1260.2546 & 0.4831 & $\mathrm{NaN}$ & 0.7334 \\
\hline G72-2 & unknown & & $\mathrm{NaN}$ & $\mathrm{NaN}$ & $\mathrm{NaN}$ & 1049.2592 & 185.7085 & $\mathrm{NaN}$ & 0.6928 \\
\hline DI & unknown & 1 & 0.0004 & 0.1292 & $\mathrm{NaN}$ & 0.0018 & 0.0278 & 0.0004 & $\mathrm{NaN}$ \\
\hline MC Anion 090113 & unknown & & $\mathrm{NaN}$ & 0.1745 & $\mathrm{NaN}$ & 0.0312 & 0.0043 & 0.0103 & $\mathrm{NaN}$ \\
\hline MC Cation 090113 & unknown & 1 & 0.0042 & 0.0295 & 0.0303 & 0.0112 & 0.1125 & 0.0888 & $\mathrm{NaN}$ \\
\hline DI & unknown & & $\mathrm{NaN}$ & 0.026 & $\mathrm{NaN}$ & $\mathrm{NaN}$ & 0.0042 & 0.0022 & $\mathrm{NaN}$ \\
\hline Shutdown & unknown & & $\mathrm{NaN}$ & $\mathrm{NaN}$ & $\mathrm{NaN}$ & $\mathrm{NaN}$ & $\mathrm{NaN}$ & $\mathrm{NaN}$ & $\mathrm{NaN}$ \\
\hline \begin{tabular}{|l|} 
Shutdown \\
\end{tabular} & unknown & & $\mathrm{NaN}$ & NaN & $\mathrm{NaN}$ & $\mathrm{NaN}$ & $\mathrm{NaN}$ & $\mathrm{NaN}$ & $\mathrm{NaN}$ \\
\hline
\end{tabular}


Table A11: Greenland Ice Sheet Margins 2008 Dissolved Iron (Fe)

\begin{tabular}{|c|c|c|c|c|}
\hline & Sample ID & Sample Type & Nutrient sample? & Fe concentration $(\mu \mathrm{M})$ \\
\hline \multicolumn{5}{|l|}{ Clean Lab Blanks } \\
\hline & MQ_10.28.08 & clean lab blank & $\mathrm{n} / \mathrm{a}$ & 0.0461 \\
\hline & MQ 10.29.08 & clean lab blank & $\mathrm{n} / \mathrm{a}$ & 0.0056 \\
\hline & Milli-Q1 & clean lab blank & yes & 0.031 \\
\hline & Milli-Q2 & clean lab blank & yes & 0 \\
\hline \multicolumn{5}{|l|}{ Supraglacial } \\
\hline & G15 & MI & yes & 0.1256 \\
\hline \multicolumn{5}{|l|}{ Proglacial Lake } \\
\hline & G7 & $\mathrm{PL}$ & yes & 5.2323 \\
\hline & G67 & $\mathrm{PL}$ & yes & 4.8283 \\
\hline \multicolumn{5}{|l|}{ Proglacial Lake Outflow } \\
\hline & $\mathrm{G} 20$ & $\mathrm{LO}$ & yes & 17.462 \\
\hline \multicolumn{5}{|l|}{ Marginal Melt } \\
\hline & G58 & MM & yes & 0.2091 \\
\hline \multicolumn{5}{|l|}{\begin{tabular}{|l|} 
O Glacier \\
\end{tabular}} \\
\hline & G21 & OF & yes & 9.9741 \\
\hline \multicolumn{5}{|l|}{ M Glacier } \\
\hline & G35 & $\mathrm{MO}$ & yes & 3.54 \\
\hline & $\mathrm{G} 70$ & $\mathrm{MO}$ & yes & 4.0887 \\
\hline \multicolumn{5}{|l|}{ Groundwater } \\
\hline & G39 & GW & no & 0.311 \\
\hline & GM50 & $\mathrm{GW}$ & no & 3.0239 \\
\hline & GM51 & GW & no & 431.2633 \\
\hline & GM52 & GW & no & 143.227 \\
\hline & GM53 & GW & no & 4.6735 \\
\hline & GM54 & GW & no & 1.6652 \\
\hline \multicolumn{5}{|l|}{\begin{tabular}{|l} 
N Glacier \\
\end{tabular}} \\
\hline & G11 & $\mathrm{NO}$ & yes & 7.0796 \\
\hline & G12 & $\mathrm{NO}$ & yes & 3.2296 \\
\hline & G29 & $\mathrm{NO}$ & yes & 7.0217 \\
\hline & G49 & $\mathrm{NO}$ & yes & 9.3351 \\
\hline & G56 & $\mathrm{NO}$ & yes & 2.4776 \\
\hline & G57 & $\mathrm{NO}$ & yes & 2.2206 \\
\hline & G61 & $\mathrm{NO}$ & yes & 3.5426 \\
\hline & G63 & $\mathrm{NO}$ & yes & 2.8707 \\
\hline & G65 & $\mathrm{NO}$ & yes & 3.2424 \\
\hline & G66 & $\mathrm{NO}$ & yes & 2.6434 \\
\hline & G68 & $\mathrm{NO}$ & yes & 2.7228 \\
\hline & G69 & $\mathrm{NO}$ & yes & 2.5264 \\
\hline & G71 & $\mathrm{NO}$ & yes & 4.2826 \\
\hline \multicolumn{5}{|l|}{ Fjord Samples } \\
\hline & G72 & $\mathrm{F}$ & yes & 0.0519 \\
\hline & G75 & $\mathrm{F}$ & yes & -0.0092 \\
\hline & G76 & SWF & no & 2.8796 \\
\hline & G79 & SWF & yes & 2.3627 \\
\hline
\end{tabular}




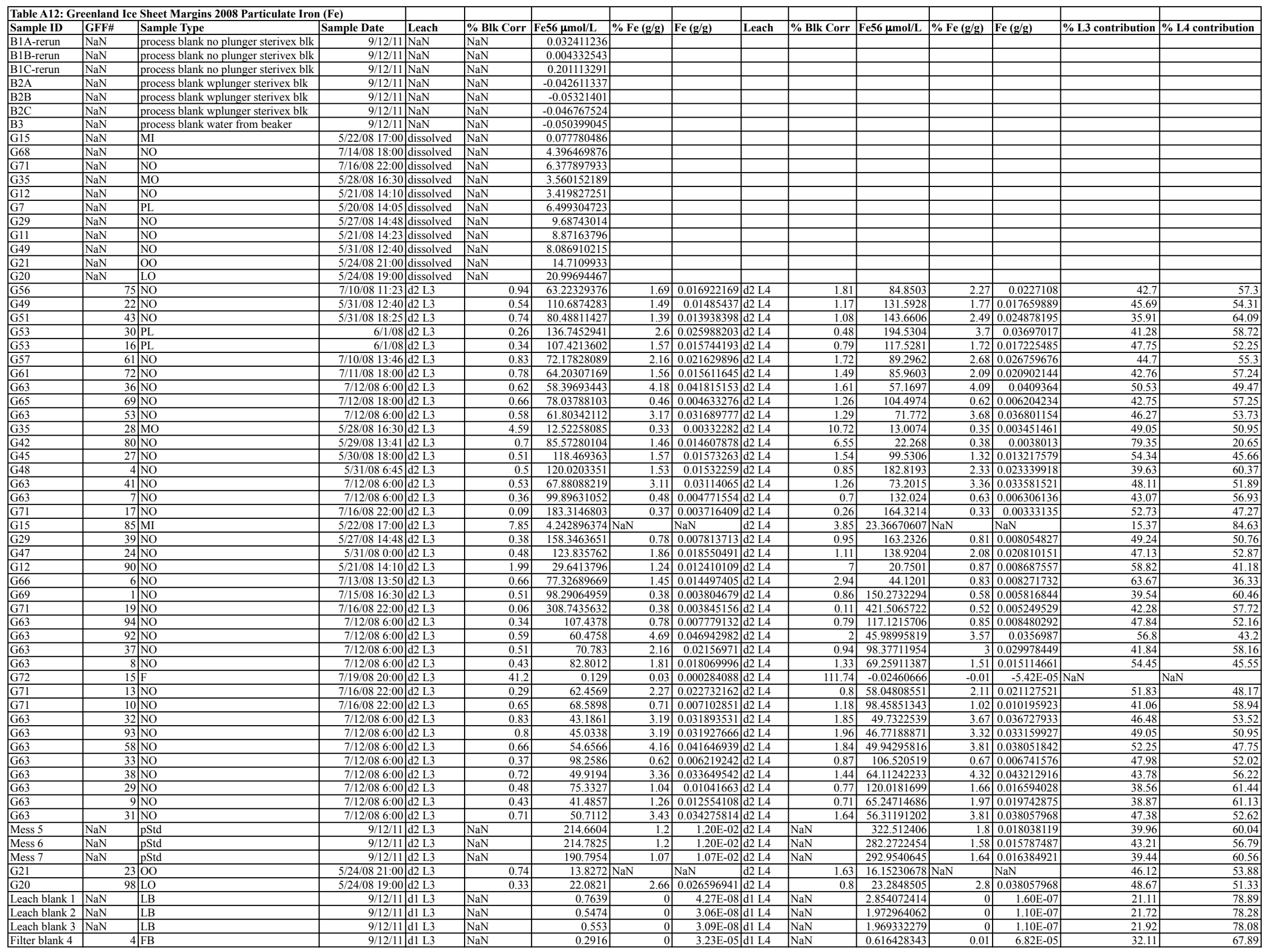




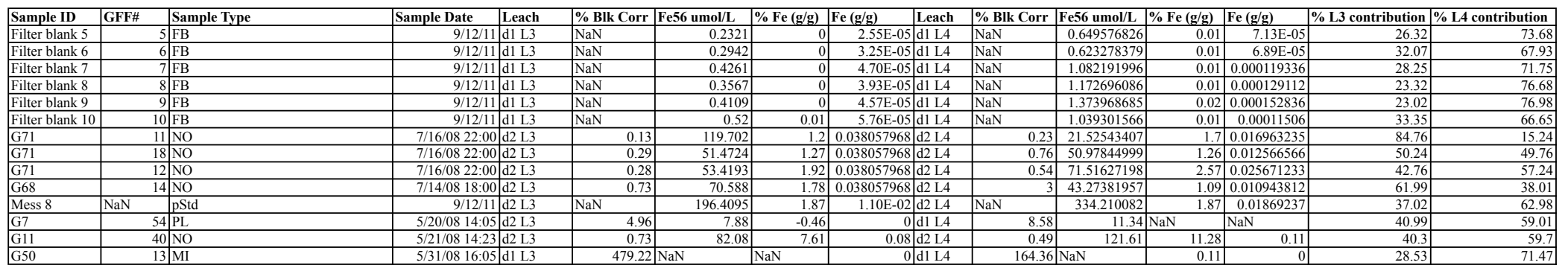




\section{Appendix A2 \\ Supplemental Material for Chapter 3: Molecular-level characterization of dissolved organic matter associated with the Greenland ice sheet}

Table EA1. List of $\mathrm{m} / \mathrm{z}$ values used for internal calibration of positive and negative ion mode data.

Figure EA1. Negative ion mode van Krevelen diagrams illustrating potential

contamination present within the Supraglacial Inland, Subglacial May, and Subglacial July-1 samples. 
Table A1. List of $m / z$ values used for internal calibration of (A) positive ion mode data and (B) negative ion mode data. Exact mass refers to the mass calculated from the elemental formula, and charged mass is the exact mass value corrected for positive mode (by adding a $\mathrm{Na}$ atom and subtracting an electron) or negative mode (by subtracting a $\mathrm{H}$ atom and adding an electron). For the positive ion mode data, we utilized $\mathrm{Na}$ adducts. These compounds were chosen because of their frequent occurrence among the different samples analyzed in each mode, and their low error of observed $\mathrm{m} / \mathrm{z}$ values (e.g. the error in mass accuracy ranged from 0.5 to 1.4 for the positive mode calibrants, and 0.3 to 0.8 ppm for the negative ion mode calibrants). In positive mode, calibrants were present in at least six of the seven samples, and in negative mode, calibrants were present in at least half the samples. On occasion, calibrants were added for specific spectra when the original list of calibrants was insufficient to calibrate the desired mass range. In positive mode the internal calibrants span the full range of observed $\mathrm{m} / \mathrm{z}$ values; whereas, in negative mode it was not possible to find calibrants above $\sim 600 \mathrm{~m} / \mathrm{z}$ that fit our criteria. However, it is unlikely that the mass error of peaks outside our calibrated range fall outside the $1 \mathrm{ppm}$ error set by the external calibrants because all of the negative mode samples were run within one week.

\section{A. Positive Mode Calibrants (Na Adducts)}

\begin{tabular}{llrr}
\hline & Elemental Formula & Exact Mass & Charged Mass \\
\hline 1 & $\mathrm{C}_{8} \mathrm{H}_{18} \mathrm{O}_{5}$ & 194.115423 & 217.104642 \\
2 & $\mathrm{C}_{10} \mathrm{H}_{22} \mathrm{O}_{6}$ & 238.141638 & 261.130856 \\
3 & $\mathrm{C}_{12} \mathrm{H}_{26} \mathrm{O}_{7}$ & 282.167853 & 305.157071 \\
4 & $\mathrm{C}_{17} \mathrm{H}_{36} \mathrm{O}_{6}$ & 336.251188 & 359.240407 \\
5 & $\mathrm{C}_{24} \mathrm{H}_{38} \mathrm{O}_{4}$ & 390.277009 & 413.266228 \\
6 & $\mathrm{C}_{18} \mathrm{H}_{38} \mathrm{O}_{10}$ & 414.246497 & 437.235715 \\
7 & $\mathrm{C}_{20} \mathrm{H}_{42} \mathrm{O}_{11}$ & 458.272712 & 481.261930 \\
8 & $\mathrm{C}_{22} \mathrm{H}_{46} \mathrm{O}_{12}$ & 502.298926 & 525.288145 \\
9 & $\mathrm{C}_{24} \mathrm{H}_{50} \mathrm{O}_{13}$ & 546.325141 & 569.314360 \\
10 & $\mathrm{C}_{26} \mathrm{H}_{54} \mathrm{O}_{14}$ & 590.351356 & 613.340574 \\
11 & $\mathrm{C}_{28} \mathrm{H}_{58} \mathrm{O}_{15}$ & 634.377571 & 657.366789 \\
12 & $\mathrm{C}_{30} \mathrm{H}_{62} \mathrm{O}_{16}$ & 678.403785 & 701.393004 \\
13 & $\mathrm{C}_{37} \mathrm{H}_{68} \mathrm{O}_{12}$ & 704.471077 & 727.460296 \\
14 & $\mathrm{C}_{35} \mathrm{H}_{62} \mathrm{O}_{16}$ & 738.403785 & 761.393004 \\
15 & $\mathrm{C}_{42} \mathrm{H}_{86} \mathrm{O}_{15}$ & 830.596672 & 853.585890 \\
16 & $\mathrm{C}_{45} \mathrm{H}_{92} \mathrm{O}_{16}$ & 888.638536 & 911.627755 \\
\hline
\end{tabular}




\section{B. Negative Mode Calibrants}

\begin{tabular}{llrr}
\hline & Elemental Formula & \multicolumn{1}{c}{ Exact Mass } & Charged Mass \\
\hline 1 & $\mathrm{C}_{10} \mathrm{H}_{16} \mathrm{O}_{6}$ & 232.094688 & 231.087411 \\
2 & $\mathrm{C}_{10} \mathrm{H}_{21} \mathrm{O}_{5} \mathrm{~N}_{3}$ & 263.148120 & 262.140844 \\
3 & $\mathrm{C}_{13} \mathrm{H}_{20} \mathrm{O}_{6}$ & 272.125988 & 271.118711 \\
4 & $\mathrm{C}_{13} \mathrm{H}_{10} \mathrm{O}_{9}$ & 310.032481 & 309.025205 \\
5 & $\mathrm{C}_{16} \mathrm{H}_{24} \mathrm{O}_{8}$ & 344.147117 & 343.139841 \\
6 & $\mathrm{C}_{24} \mathrm{H}_{18} \mathrm{O}_{3} \mathrm{~N}_{2}$ & 382.131742 & 381.124466 \\
7 & $\mathrm{C}_{19} \mathrm{H}_{24} \mathrm{O}_{9}$ & 396.142032 & 395.134755 \\
8 & $\mathrm{C}_{21} \mathrm{H}_{26} \mathrm{O}_{10}$ & 438.152597 & 437.145320 \\
9 & $\mathrm{C}_{25} \mathrm{H}_{32} \mathrm{O}_{8}$ & 460.209718 & 459.202441 \\
10 & $\mathrm{C}_{21} \mathrm{H}_{24} \mathrm{O}_{14}$ & 500.116605 & 499.109329 \\
11 & $\mathrm{C}_{27} \mathrm{H}_{26} \mathrm{O}_{12}$ & 542.142426 & 541.135149 \\
12 & $\mathrm{C}_{28} \mathrm{H}_{24} \mathrm{O}_{15}$ & 600.111520 & 599.104243 \\
13 & $\mathrm{C}_{26} \mathrm{H}_{52} \mathrm{O}_{15}$ & 604.330620 & 603.323344 \\
\hline
\end{tabular}


EA Figure 1. Negative ion mode van Krevelen diagrams illustrating the potential contamination present within the Supraglacial Inland (A), Subglacial May (B), and Subglacial July-1 (C) samples. The contamination was detected in the Yellow Snow mass spectra, likely originating from plasticizers, and consisted of an 18 peak series. Peaks from this potential contamination found in the Supraglacial Inland, Subglacial May, and Subglacial July-1 samples are outlined in red in panels A, B, and C respectively. In Supraglacial Inland the potential contamination represented 6 out of 1865 total sample peaks $(0.35 \%)$, in Subglacial May the potential contamination represented 9 out of 1737 total sample peaks $(0.52 \%)$, and in Subglacial July-1 the potential contamination represented 8 out of 3330 total sample peaks $(0.24 \%)$. The colored boxes represent elemental compositions for some major compound classes, as approximated from Kim et al. (2003) and Hedges (1990). The grey box represents condensed hydrocarbons, the blue box represents lipids, the green box represents lignin, the yellow box represents proteins, and the pink box represents carbohydrates. The black oval represents elemental formula assignments for a sample of Suwannee River Fulvic Acid. 


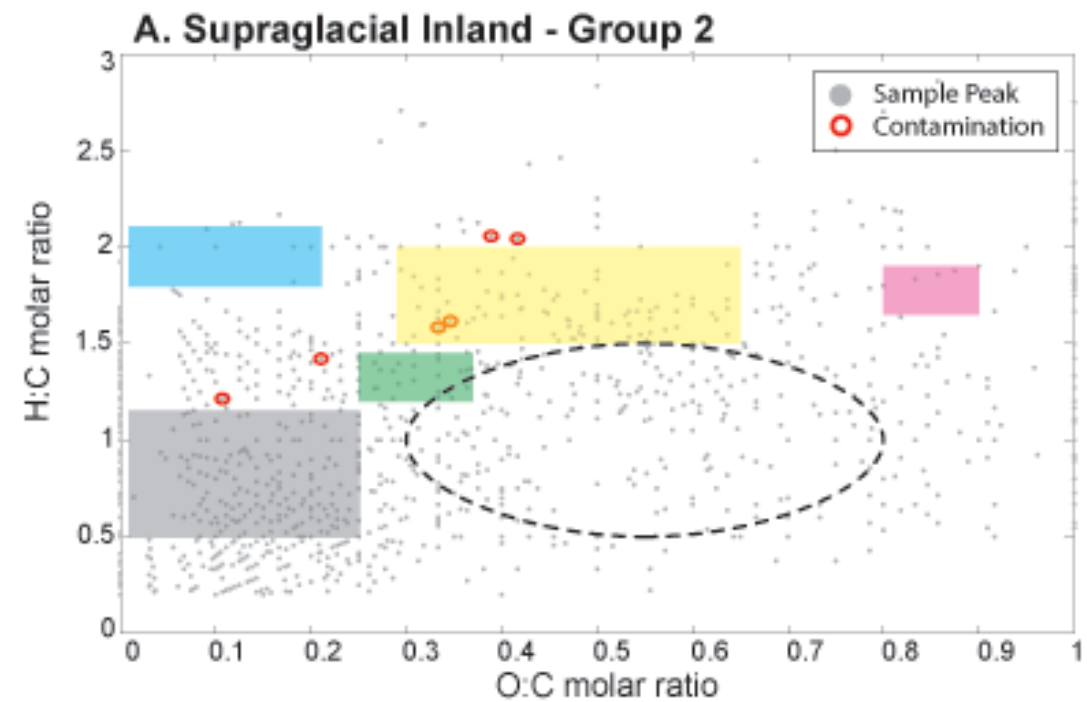

B. Subglacial May - Group 3

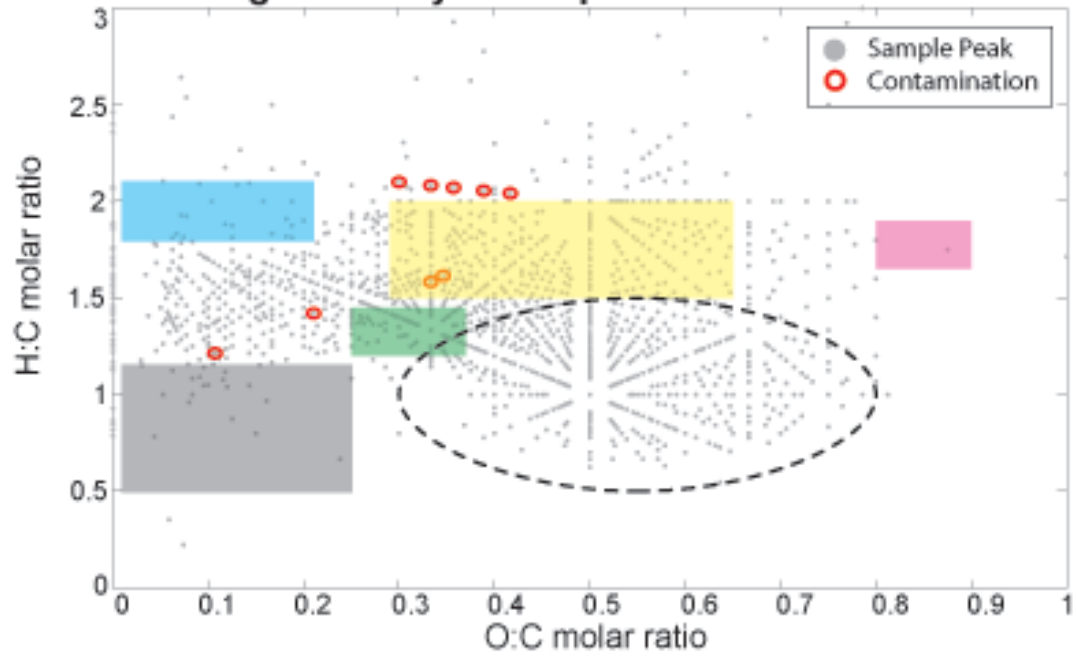

C. Subglacial July-1 - Group 4

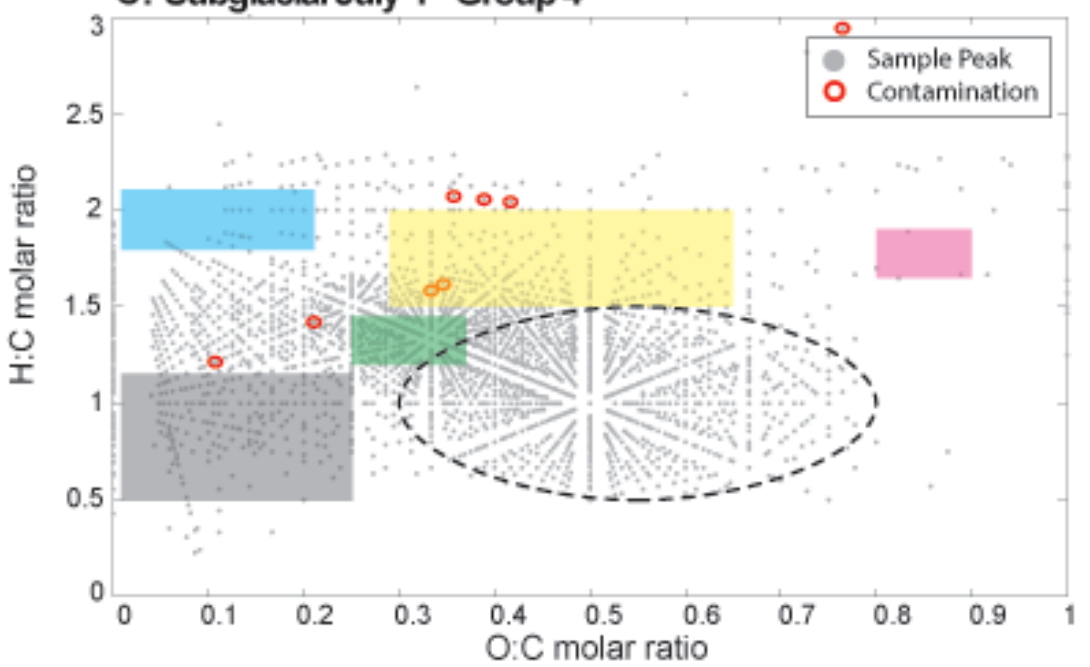

Figure EA1. 